$$
\begin{gathered}
\text { UNIVERSIDADE DE SÃO PAULO } \\
\text { INSTITUTO DE FÍSICA } \\
\text { INSTITUTO DE QUÍMICA } \\
\text { INSTITUTO DE BIOCIÊNCIAS } \\
\text { FACULDADE DE EDUCAÇÃO }
\end{gathered}
$$

PROGRAMA DE PÓS-GRADUAÇÃO INTERUNIDADES EM ENSINO DE CIÊNCIAS

\title{
JULIANA RODRIGUES
}

\section{ESTUDANDO A ALFABETIZAÇÃO CIENTÍFICA POR MEIO DE VISITA ROTEIRIZADA A UMA EXPOSIÇÃO DE JARDIM BOTÂNICO}


JULIANA RODRIGUES

\title{
ESTUDANDO A ALFABETIZAÇÃO CIENTÍFICA POR MEIO DE VISITA ROTEIRIZADA A UMA EXPOSIÇÃO DE JARDIM BOTÂNICO
}

\author{
Dissertação de mestrado apresentada ao \\ Programa de Pós-Graduação Interunidades em \\ Ensino de Ciências, da Universidade de São \\ Paulo, como parte dos requisitos para a obtenção \\ do título de Mestra em Ensino de Ciências \\ Área de concentração: Ensino de Ciências
}

ORIENTADORA: Prof ${ }^{a}$ Dra. Martha Marandino

(VERSÃO CORRIGIDA)

São Paulo

2017 
AUTORIZO A REPRODUÇÃO E DIVULGAÇÃO TOTAL OU PARCIAL DESTE TRABALHO, POR QUALQUER MEIO CONVENCIONAL OU ELETRÔNICO, PARA FINS DE ESTUDO E PESQUISA, DESDE QUE CITADA A FONTE.

\section{Preparada pelo Serviço de Biblioteca e Informação do Instituto de Física da Universidade de São Paulo}

Rodrigues, Juliana

Estudando a alfabetização científica por meio de visita roteirizada a uma exposição no jardim botânico. São Paulo, 2017.

Dissertação (Mestrado) - Universidade de São Paulo. Faculdade de Educação, Instituto de Física, Instituto de Química e Instituto de Biociências.

Orientador: Profa. Dra. Martha Marandino

Área de Concentração: Ensino de Biologia

Unitermos: 1. Biociências - Estudo e ensino; 2. Educação em museus; 3. Ação educativa-cultural; 4. Ensino.

USP/IF/SBI-024/2017 


\section{FOLHA DE APROVAÇÃO}

RODRIGUES, Juliana

ESTUDANDO A ALFABETIZAÇÃO CIENTÍFICA POR MEIO DE VISITA ROTEIRIZADA A UMA EXPOSIÇẪO DE JARDIM BOTÂNICO

Dissertação apresentada ao Programa Interunidades em Ensino de Ciências da Universidade de São Paulo para obtenção do título de Mestra em Ciências. Área de concentração: Biologia

Aprovado em:

Banca Examinadora

Prof. Dr.

Julgamento:

Prof. Dr.

Julgamento:

Prof. Dr.

Julgamento:
Instituição:

Assinatura:

Instituição:

Assinatura:

Instituição:

Assinatura: 
Não basta abrir a janela para ver os campos e o rio. Não é o bastante não ser cego para ver as árvores e as flores

(Fernando Pessoa, Poemas Completos de Alberto Caeiro. São Paulo: Nobel, 2008. p. 159) 


\section{AGRADECIMENTOS}

Muitas pessoas estiveram comigo e participaram do processo de desenvolvimento deste trabalho de alguma forma. Sou muito grata e compartilho um pouquinho desse sentimento e trajetória nestes breves excertos:

À Profa. Dra. Martha Marandino, que durante o processo de orientação, me ensinou com gestos de carinho, preocupação, confiança e paciência e em muito contribuiu para o meu desenvolvimento em âmbito acadêmico, científico, intelectual e pessoal.

À CAPES pela provisão da bolsa que subsidiou a dedicação integral na primeira parte do mestrado, tempo decisivo para o delineamento e andamento desta pesquisa.

Ao Santander Universidades que, ao conceder a bolsa de pesquisa no exterior, me permitiu um aprofundamento maior na área de educação em museus e inspirações para o desenvolvimento do material educativo proposto neste trabalho.

Aproveito também para agradecer à Prof. Dra. Marta Lourenço e à educadora Raquel Barata por terem me recebido carinhosamente no MUHNAC/UL, por terem me possibilitado conversar com profissionais e conhecer um pouco das dinâmicas dos setores educativos de diversos museus de Lisboa, Coimbra e Porto, em Portugal.

Ao Instituto Nacional de Ciência e Tecnologia em Toxinas/INCTTOX/CNPq que financiou os custos de ilustração, edição e também a impressão do roteiro.

Ao Instituto de Botânica pela autorização e oportunidade de realização deste trabalho no Jardim Botânico. Em especial agradeço à estimada Tânia Maria Cerati pela 'abertura de portas', pela inspiração temática, pelo incentivo constante e dicas valiosas na realização deste trabalho. Também agradeço as dicas da equipe de monitores do núcleo de Educação Ambiental na etapa de validação do material.

Aos Profs. Drs. Antônio Carlos Rodrigues de Amorim e Lucia Helena Sasseron Roberto, que participaram da banca de qualificação e de defesa e, com seus olhares críticos e atentos, muito me auxiliaram no aprimoramento deste trabalho.

Aos funcionários da Secretaria de Pós Graduação do Programa Interunidades em Ensino de Ciências Thomas, Rosana e Silvana, que sempre me auxiliaram na questões da pós graduação com respeito, carinho e empatia.

À Antonia, Laura e Maria, visitantes do Jardim Botânico de São Paulo, que prontamente se predispuseram a realizar a visita roteirizada e a participar da pesquisa. 
Ao Brucce Sanderson e Rodolph Delfino Sartin pela disposição em me acompanhar e compartilhar seus "olhares botânicos" na exploração da Trilha da Nascente no Jardim Botânico de São Paulo.

Ao Marcos Tubero e Adriana Silva pela amizade de longa data, pelos sorrisos largos e fáceis e pelo o auxílio na confecção ilustrada da primeira versão do roteiro.

À Fernanda Buzzo Gerardi - amiga, bióloga e ilustradora admirável - e ao Fabiano - designer gráfico - que, com lindos traços, compuseram a parte gráfica e deram vida ao roteiro de visita proposto neste trabalho.

Também agradeço a Débora, Giullia e Laura, revisoras mirins, que se dispuseram a analisar o material com animação, criticidade e primazia. E ao Marsívio Pereira pelo apoio e vibrações positivas ao longo do desenvolvimento do roteiro e ao Ricardo Streich pelo carinho na revisão desse trabalho.

Ao pessoal do GEENF - Grupo de Estudo e Pesquisa em Educação Não Formal e Divulgação em Ciência - além do compartilhamento de aprendizados e pela participação ativa nas etapas de desenvolvimento e validação do roteiro - agradeço pela amizade, carinho e preocupação que sempre tiveram para comigo, cada qual à sua maneira: Adriana Pugliese; Adriano Dias Oliveira; Barbara Milan Martins; Cynthia Iszlaji; Djana Contier; Fernanda Vidal; Graziele Scalfi; Jéssica Norberto; Juliana Pavani Bueno; Luciana Conrado Martins; Natália Campos; Márcia Fernandes Lourenço, Maria Paula Correia de Souza e Mauricio Salgado.

À Ciência Prima, em especial agradeço Aníbal Fonseca de Figueiredo Neto pelo apoio e incentivo nos primeiros passos para a realização da pós-graduação, à Girlene Jordão amizade e por ser minha companheira de aventuras e Vilma Costa por ter me 'adotado' em São Paulo e cuidado tanto de mim.

Agradeço também às amizades que fiz no Catavento Educacional e no Projeto Brinca Ciência que ocorreu na Sabina - Escola Parque do Conhecimento. Trabalhar com pessoas tão competentes e engajadas tornaram-me uma pessoa apaixonada pelo processo educativo em espaços de educação não formal.

À turma do SESCOOP - Serviço Nacional de Aprendizagem do Cooperativismo - apoio e compreensão nos momentos turbulentos. Aqui fiz amizade com pessoas especiais: Ana Claudia Banin, Fabio Pellaes, Fernanda Vieira dos Santos, Nilzete Mirna Taino, Paula Salvini Olah, Paulo de Souza Reis, Vanessa Camargo Maestro. Também encontrei pessoas que vibravam e sempre perguntavam sobre o andamento do Mestrado: Paulo Belchior, Tatiana Manzoni, Silvia Rodrigues e Sueli Gonçalves. 
Aos profissionais da área da saúde Marco Antônio Kulik e Rodrigo Nishihara Jorge que, com um olhar voltado ao atendimento integral e na atenção disposta à minha saúde, me fizerem refletir e me auxiliaram na busca de uma melhor qualidade de vida.

Ao Arcelino que, com disposição e paciência, me mostrou possibilidades de utilização do software NVIVO. A transposição do seu conhecimento muito contribuirá para trabalhos futuros.

Aos amigos que a vida me presenteou nos últimos tempos, cuja afinidade parece vir de "outras vidas": Daniela Mehmari Fais, Mateus Ribeiro Fais e, seu filhinho que muito nos alegra, Lucca Mehmari Fais, agradeço por estarem sempre por perto, independentemente do momento ser feliz ou triste.

Aos meus grandes amigos, Bruna Alves, Jussara de Souza Marcelino, Giovanni Machi, Robson Bello, Thiago Martins Chueri e Zaqueu Vieira pela amizade sincera e apoio incondicional - cada qual a sua maneira - em diversos momentos importantes.

Por fim, e de essencial relevância, agradeço enormemente minha família, porto seguro, onde encontro - sempre que preciso - inspiração e forças para seguir em frente, amor para me lembrar dos valores mais importantes da vida e base de sustentação para os momentos de superação.

Ao meu pai, Antonio Gonzaga Rodrigues, por sempre me ensinar a importância dos estudos, a ser resiliente, a acreditar no meu potencial e lutar pelos meus sonhos.

À minha mãe, Ivete Cavalheiro, exemplo de otimismo e perseverança e que esteve ao meu lado quando achava que não ia conseguir fazer sozinha.

Ao meu irmão, Leonardo Cavalheiro Rodrigues, obrigada por existir e ser meu amigo. Por, e com, você aprendi a ser mais forte, a dividir e a ser uma pessoa melhor.

À minha madrinha amada, Maria Clarete Rodrigues, pelo carinho e apoio ao longo de toda minha vida.

Aos meus primos, tios e avó, agradeço muito por me ensinarem a importância de se considerar família enquanto unidade, pelos princípios e valores ensinados. Amo cada um à sua maneira.

Ao Matteo Finazzo Neto, meu leal companheiro, agradeço por estar ao meu lado em todos os momentos e por compreender e apoiar as minhas escolhas. Também agradeço à sua família, que agora também faz parte da minha, pela acolhida, amor e carinho. 


\section{RESUMO}

\section{RODRIGUES, Juliana. Estudando a Alfabetização Científica por meio de visita}

roteirizada a uma exposição de jardim botânico. Dissertação (Mestrado em Educação)

- Faculdade de Educação, Universidade de São Paulo, 2017.

A disseminação das ciências naturais em espaços de educação não formal tem sido tema de discussões na área de ensino de ciências na busca de elementos que possibilitem a compreensão das suas potencialidades e dos seus desafios. Investigações atuais têm buscando compreender o potencial dos museus de promover o processo de Alfabetização Científica de seus visitantes por meio de ações educativas. Dentre os elementos na educação em museus estão os materiais educativos e, inseridos neste conjunto, temos os roteiros de visita a exposições. Nesta perspectiva, o objetivo deste trabalho foi analisar o processo de Alfabetização Científica em visitas de famílias à Trilha da Nascente do Jardim Botânico de São Paulo a partir do uso de um roteiro elaborado sob a perspectiva da Alfabetização Científica. Também foi intenção da pesquisa compreender o papel deste roteiro - tanto seu processo de elaboração quanto seus efeitos e potenciais - como estratégia para a promoção do processo de Alfabetização Científica junto a famílias que visitam este local. A confecção do roteiro teve por base literatura e a experiência profissional das pesquisadoras envolvidas, tendo passado por um processo de validação envolvendo, diferentes atores, especialistas e o próprio público. A versão final do roteiro, fornecido como parte de um kit com outros objetos como monóculo e lupa, foi aplicado e avaliado na visita de uma família. Do ponto de vista metodológico, a investigação proposta se enquadra como uma pesquisa qualitativa, tendo por foco a perspectiva dos participantes na busca de responder os potenciais e limitações das visitas roteirizadas e seus possíveis impactos nos visitantes do Jardim Botânico em São Paulo. Os dados em categorias pré-estabelecidas - indicadores de Alfabetização Científica e habilidades investigativas -, se constituíram como a base para o estudo da fala dos sujeitos na interação com o roteiro durante a vista a Trilha da Nascente. Esse procedimento nos revelou evidências de que a Alfabetização Científica está em processo para os integrantes da família. Desse modo, apontamos que a produção e o uso de roteiros em visitas a museus podem promover a reflexão e auxiliar o desenvolvimento das atividades dos setores educativos de museus.

Palavras-chave: Roteiro de visita, educação em museus, educação não formal, Alfabetização Científica. 


\begin{abstract}
RODRIGUES, Juliana. Researching the Scientific Literacy by means of a scripted visit to a botanical garden's exhibition. Dissertação (Mestrado em Educação) Faculdade de Educação, Universidade de São Paulo, 2017.

The spread of natural sciences in non-formal education has been subject of discussions in the area of science education in search for elements that allow the understanding of their potential and their challenges. Current investigations are seeking to understand the potential of museums to promote scientific literacy process of their visitors by means of educational activities that develop. Among the elements in education in museums are educational materials and included in this set, we have the visit scripts to exhibitions. In this perspective, the objective of this study was to analyze the scientific literacy process in family visits to the "Trilha da Nascente" of Botanical Garden of São Paulo from the use of a developed script from the perspective of the Scientific literacy. It was also the intention of the research to understand the role of this script as a strategy for the promotion of the process of Scientific Literacy with the families who visit this site. The potential of the material was investigated as an educational resource for the promotion of Scientific Literacy, analyzing both the process of elaboration of the material and its effects when applied to a visiting family of "Trilha da Nascente" . The preparation of the script was based on literature and professional experience of the involved researchers, having passed through a validation process involving different actors, experts and the public itself. The final version of the script provided as part of a kit with other objects such as monocular and magnifying glass, was applied and evaluated on a family visit. From a methodological point of view, the proposed research fits into the perspective of qualitative research, with the focus on the perspective of the participants in the quest to answer the potential and limitations of scripted visits and their possible impacts on Botanical Garden visitors in São Paulo. The data in predetermined categories - scientific literacy indicators and investigative skills-, constituted as the basis for the study of the subjects' speeches in the interaction with the script during the visit to the "Trilha da Nascente". This procedure revealed us evidence that the Scientific Literacy is in process for the family members. Thereby, we point out that the production and use of scripts in visits to museums can promote reflection and assist the development of the activities of educational museums sectors.
\end{abstract}

Keywords: Visit script, museum education, non-formal education, scientific literacy. 


\section{LISTA DE FIGURAS}

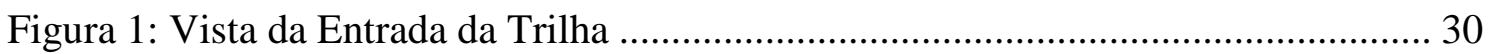

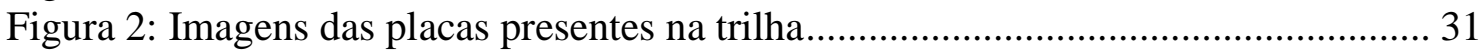

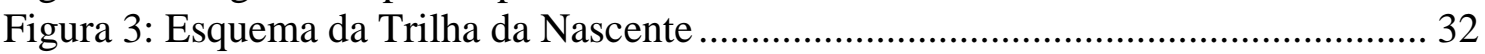

Figura 4: Primeira versão ilustrada do roteiro [interior] ............................................ 40

Figura 5: Primeira versão ilustrada do roteiro [externo e abas] ...................................... 41

Figura 6: Primeira imagem enviada para aprovação do estilo de traço da ilustração .... 42

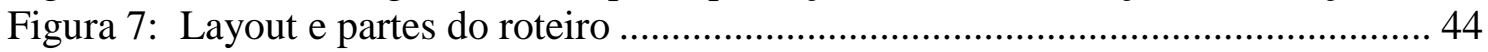

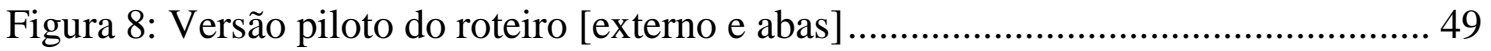

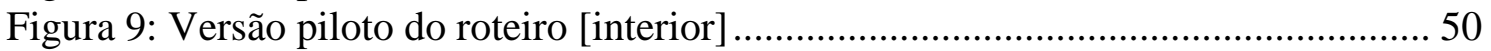

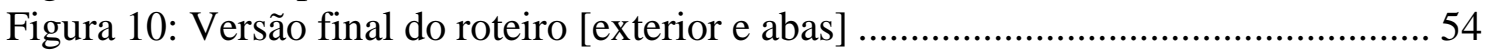

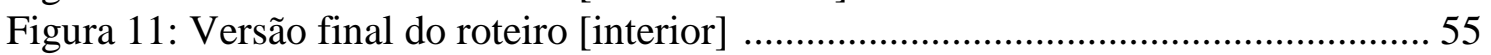

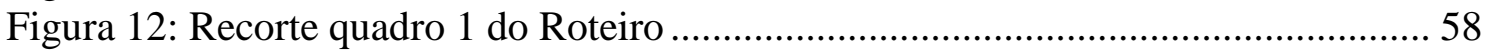

Figura 13: Imagem da placa 1 - Trilha do nascente ................................................. 59

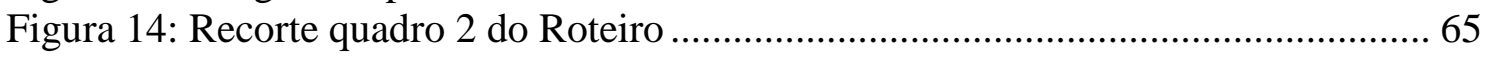

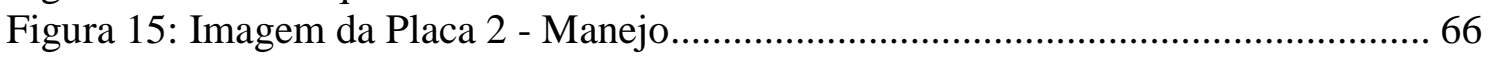

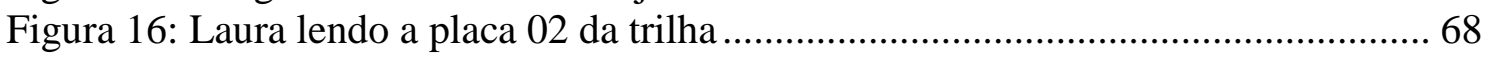

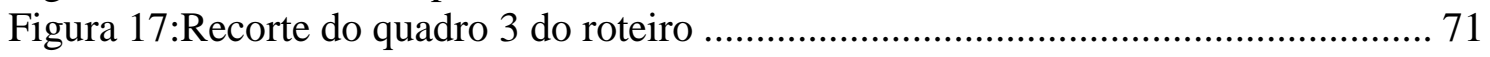

Figura 18: Família discutindo sobre a árvore mantida no percurso .............................. 73

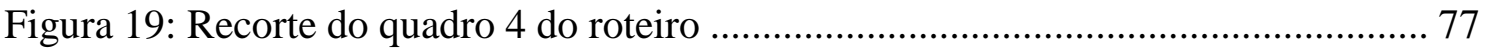

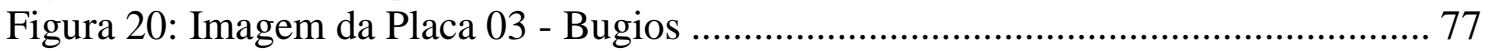

Figura 21: Interação familiar e uso do monóculo para visualizar os frutos .................... 80

Figura 22: Maria mostrando para Antônia uma das sementes encontradas no percurso 81

Figura 23: Observação dos bugios com monóculo..................................................... 81

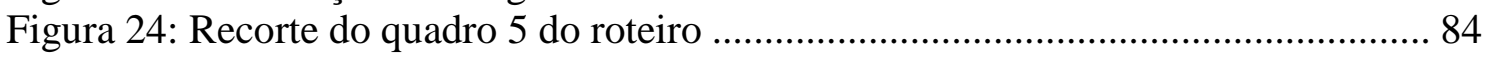

Figura 25: Maria observando o tronco de uma árvore com liquens. .............................. 86

Figura 26: Laura e Antônia observam o tronco de uma árvore com liquens com uma

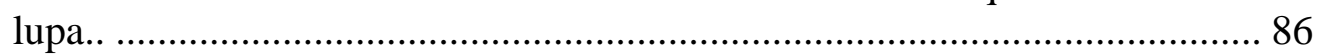

Figura 27: Recorte do quadro 6 do roteiro Fonte: elaboração própria ........................ 90

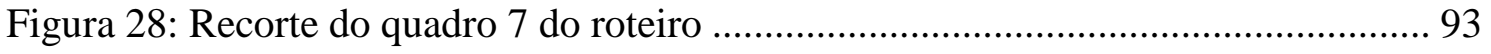

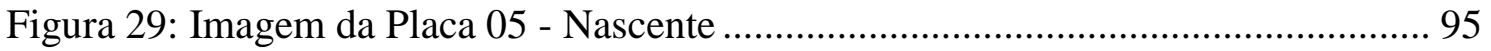

Figura 30: Maria mostra a nascente para Antônia enquanto Laura lê a placa 05 da trilha

Figura 31: Recorte do quadro 8 do roteiro

Figura 32: Família observa a garrafa PET e interage ................................................. 102

Figura 33: Presença de indicadores de AC identificadas nas SDRs ............................. 112

Figura 34: Presença de indicadores de AC identificadas nos eixos temáticos ............. 113 


\section{SUMÁRIO}

1. INTRODUÇÃ

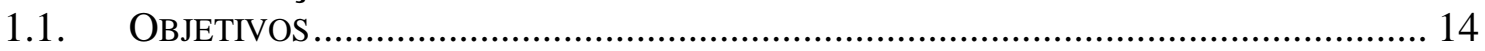

2. ALFABETIZAÇÃO CIENTÍFICA E MUSEU ............................................... 15

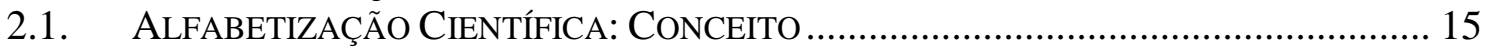

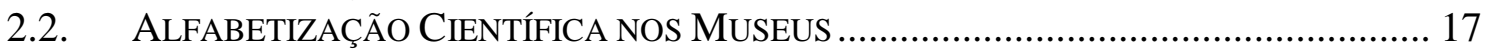

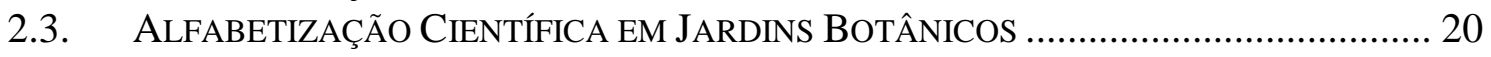

2.4. AlFABETIZAÇÃo CiENTÍFICA EM MATERIAIS DidÁtICOS..................................... 23

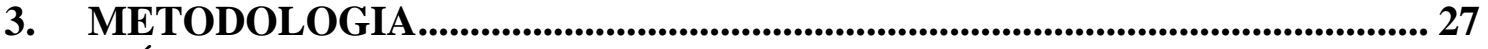

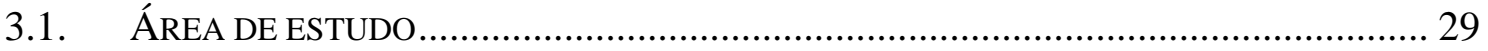

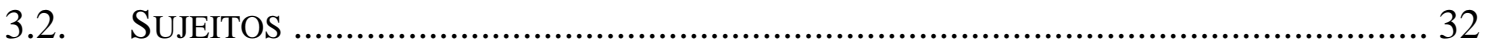

3.3. O InStRUMENTO DE PESQUiSA: O ROTEIRO DE VISITA A TRILHA DA NASCENTE. 33

3.3.A. Processo de ProduÇão do Roteiro de Visita: CONSTRUindo o ROTEIRO

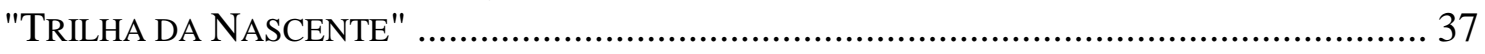

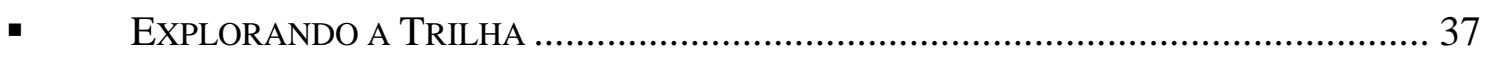

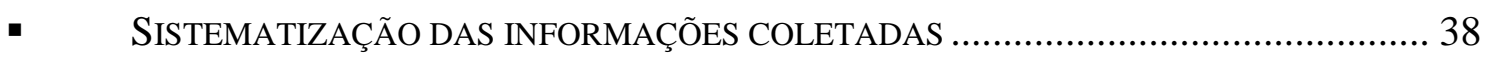

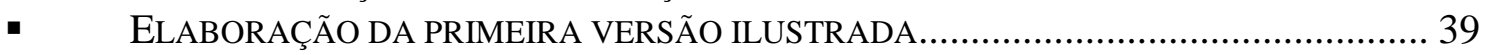

- $\quad$ ElaboraÇÃo da VERSÃo PILOTO E FINAL DO ROTEIRO ........................................ 41

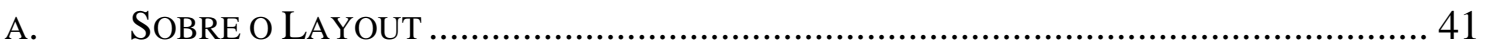

B. SOBRE AS ATIVIDADES DO ROTEIRO PILOTO PARA A PROMOÇÃO DE AC EM VISITAS

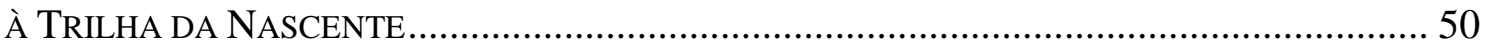

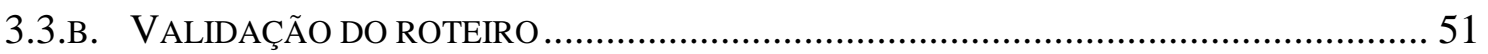

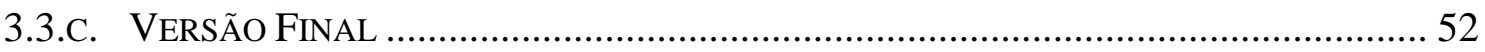

4. O POTENCIAL DO USO DO ROTEIRO NO PROCESSO DE AC EM VISITA A TRILHA DA NASCENTE: O QUE DIZEM OS DADOS? .................... 56

4.1. COMENTÁRIO INICIAL SOBRE A ANÁLISE DOS DADOS ..........................................56

4.2. A ALFABETIZAÇÃO CIENTÍFICA NA EXPERIÊNCIA DO VISITANTE USANDO O

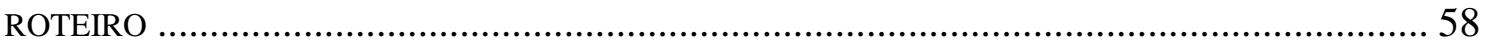

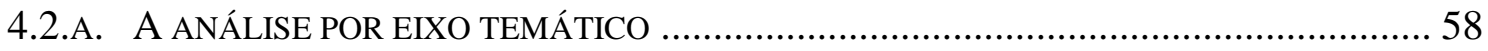

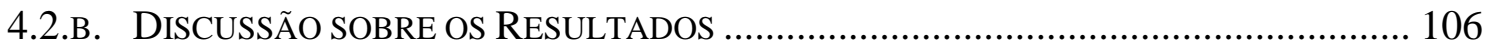

- $\quad$ SOBRE OS INDICADORES E ATRIBUTOS DE AC E AS HABILIDADES INVESTIGATIVAS

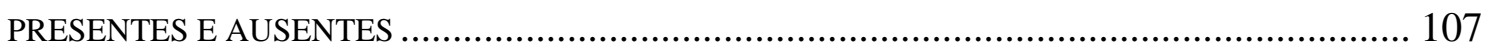

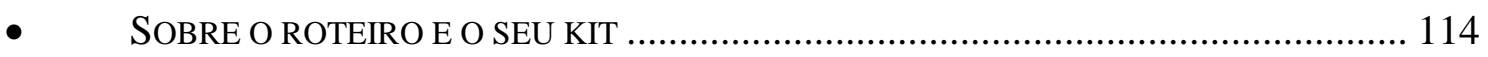

- Sobre a INTERAÇÃo dos MEMBRos da FAMília .............................................. 115

- $\quad$ SObRe AS PRÁticAs de VISITA E O USO DE ROTEIROS EM MUSEUS/JARDINS

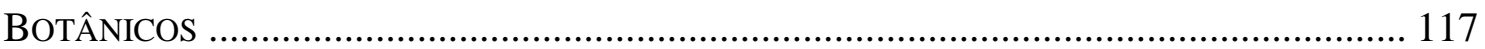

- $\quad$ SOBRE OS ASPECTOS METODOLÓGICOS DA PESQUISA............................................ 118

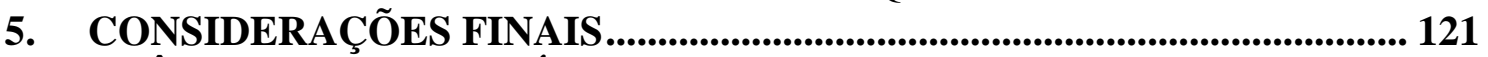

REFERÊNCIAS BIBLIOGRÁFICAS .......................................................... 122

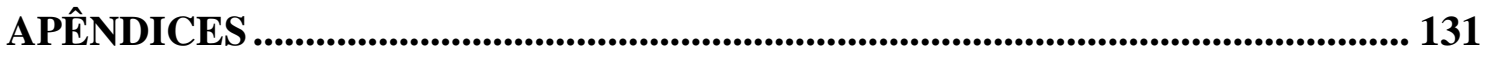




\section{INTRODUÇÃO}

Cada vez mais frequentes têm sido as pesquisas em educação em ciências que lançam mão de diferentes expressões para denotar a importância de aproximação da ciência à população. Expressões como "Alfabetização Científica", "Letramento Científico" ou "Enculturação Científica" têm sido utilizadas para identificar a importância da promoção ao acesso aos conhecimentos científicos de maneira crítica e contextualizada como forma de cidadania (SASSERON, 2008). Embora o significado dos termos indicados seja carregado de polêmicas, grande parte dos autores que discutem as definições aponta para compreensão de que os conhecimentos advindos da ciência devem ser adquiridos pelos cidadãos para a tomada de decisões necessárias no dia-a-dia. Nesse contexto, não somente as escolas, mas também os espaços de educação não formal são identificados como potenciais promotores do processo de Alfabetização Científica para um amplo público (MOREIRA, 2013; COUTINHO-SILVA et al., 2005; KRASILCHIK; MARANDINO, 2004; CAZELLI; FRANCO, 2001; CONSTANTIN, 2001).

Dentro deste quadro, pensamos a definição de educação não formal exposta neste trabalho de acordo com a proposta de Bianconi e Caruso (2005) como qualquer tentativa educacional organizada e sistemática que, normalmente, se realiza fora dos quadros do sistema formal de ensino. A busca de elementos que possibilitem a compreensão sobre os processos e ações educativas em um espaço não formal, suas potencialidades, possibilidades e problemas estão presentes nas discussões práticas e teóricas do processo de ensino e da aprendizagem em museus (SANDER, 2006).

Tomamos como base as pesquisas que fundamentam a disseminação das ciências naturais em espaços de educação não formal (como exposições de museus e outras mídias) e tem sido palco de discussões na área de ensino de ciências (MARANDINO, 2005a; NASCIMENTO; REZENDE JR., 2010). De acordo com Marandino (2011), a compreensão do processo de produção do discurso expositivo pode cooperar com as preferências e seleções para o desenvolvimento de exposições de museus de ciências.

Os museus, enquanto locais de educação não formal, possuem características particulares que, apesar de presentes também na escola ou em qualquer outro espaço educativo, ganham contornos próprios. São eles: o objeto, o tempo, o espaço e a linguagem. Assim sendo, para compreensão e estudo dos processos educativos em 
museus, sejam aqueles desenvolvidos por meio das exposições, sejam as ações educativas mais gerais, é necessário considerar tais especificidades (MARANDINO, 2008).

No que se refere às práticas educacionais desenvolvidas pelos museus, Martins (2011) revela que em sua gama de tipologias de acervos e arranjos institucionais, esses locais comportam uma diversidade de iniciativas voltadas para públicos e objetos variados. Dentre as ações educacionais desenvolvidas pelos museus a produção de materiais didáticos se faz presente na forma de impressos, objetos tridimensionais, jogos, entre outros. Essas ações são muito presentes nos museus, no entanto, ainda são pouco investigadas (ELLIS, 2002; MORTENSEN; SMART, 2007; PIRES; PIRES, 1992; STOCKLMAYER, 2002 apud CAMPOS, 2009).

A criação de materiais didáticos e culturais enquanto parte das ações educativas em museus, pode ampliar as possibilidades de aproveitamento pedagógico dos acervos, para que o visitante acentue seu espírito crítico em relação a sua realidade e daqueles que estão à sua volta (ALMEIDA, 1997). Muitos desses materiais são usados durante as visitas como apoio para o visitante e mesmo como estratégia de mediação feita por monitores. Alguns desses materiais ainda auxiliam a exploração das exposições por grupos ou indivíduos, sendo às vezes disponibilizados em sites ou distribuídos durante a visita. Assim, tais materiais podem potencializar a compreensão de ideias e o próprio processo de aprendizagem nos museus antes, durante e depois da visita.

Entendemos que os museus de ciências por meio das visitas as suas exposições podem promover processos de Alfabetização Científica junto a seus visitantes (MOREIRA, 2013; SEGARRA et. al., 2008; SOUZA, 2009; CAZELLI; FRANCO, 2001). Por Alfabetização Científica consideramos tanto a promoção da aprendizagem de ideias e conceitos científicos quanto o acesso à compreensão do processo de produção da ciência e de suas relações com a sociedade.

Sasseron (2008) notou que diferentes autores listam diversas habilidades classificadas como necessárias de serem encontradas entre os indivíduos alfabetizados cientificamente. A autora propõe em sua pesquisa três eixos estruturantes para a análise das atividades que compõem uma sequência didática, a saber: 1) compreensão básica de termos, conhecimentos e conceitos científicos fundamentais; 2) compreensão da natureza das ciências e dos fatores éticos e políticos que circundam sua prática; 3) o entendimento das relações existentes entre ciência, tecnologia, sociedade e meio-ambiente. Para ela, estes três eixos são capazes de fornecer bases suficientes e necessárias de serem consideradas no momento da elaboração e planejamento e propostas de aulas que visam 
à Alfabetização Científica (AC). Mas seria possível promover este processo de $\mathrm{AC}$ por meio de visitas a exposições de museus?

Muitas são as instituições que divulgam e realizam a educação não formal com temáticas das ciências naturais. Para o Conselho Internacional de Museus (ICOM), a definição de museu, utilizada como referência na comunidade internacional atualmente e aprovada durante a Conferência Geral 21 em Viena, Áustria, em 2007, indica que:

Um museu é uma instituição sem fins lucrativos, permanente a serviço da sociedade e de seu desenvolvimento, aberto ao público, que adquire, conserva, pesquisa, comunica e exibe o patrimônio tangível e intangível da humanidade e seu ambiente para fins de educação, estudo e diversão $\left(\mathrm{ICOM}^{1}\right)$.

Existem várias propostas de agrupar a variedade de museus existentes hoje. ALMEIDA (1997), por exemplo, propõe os seguintes grupos: a) esfera responsável público, privado; federal, estadual, municipal, universitário; b) tipo de acervo antropologia, arte contemporânea, sacra, biológico, histórico; c) áreas de pesquisa antropologia, arte, arqueologia, herpetologia, saúde pública. Considerando que os museus de ciências possuem entre suas finalidades adquirir, conservar, pesquisar e divulgar os conhecimentos referentes às áreas das ciências naturais, os Jardins Botânicos podem ser considerados uma instituição que faz parte desta tipologia de museus.

Entende-se como Jardim Botânico, segundo a resolução no 266 de 03 de agosto de 2000 do Conselho Nacional do Meio Ambiente (CONAMA), a área protegida, constituída no seu todo ou em parte, por coleções de plantas vivas cientificamente reconhecidas, organizadas, documentadas e identificadas, com a finalidade de estudo, pesquisa e documentação do patrimônio florístico do País, acessível ao público, no todo ou em parte, servindo à educação, à cultura, ao lazer e à conservação do meio ambiente (BRASIL, 2000). Nesse sentido, Linares (1994 apud SOUZA, 2009) entende os jardins botânicos como "museus vivos" e os denomina como parte dos maiores responsáveis pela divulgação de conhecimento sobre a importância do reino vegetal.

De acordo com Miller et al. (apud LORENZETTI; DELIZOICOV, 2001) as instituições que possuem coleções e exposições científicas de flora e fauna contribuem não só nas ações de conservação e pesquisa, mas como polos disseminadores de conhecimento sobre a biodiversidade, constituindo-se como centros educadores.

\footnotetext{
${ }^{1}$ Disponível em: http://icom.museum/the-vision/museum-definition/ Acesso em: jun. 2013
} 
Uma vez que neste trabalho pretende-se verificar e refletir sobre a Alfabetização Científica, nas ações educativas em espaços de educação não formal, nos apropriamos dos conceitos de Alfabetização Científica (CERATI, 2014) para fundamentar a compreensão e desenvolvimento do conhecimento das habilidades consideradas necessárias para a classificação de uma pessoa como alfabetizada cientificamente. Também de acordo com as formulações de Cerati (2014), pretendemos aplicar os conceitos desenvolvidos de apreensão de indicadores e atributos para a análise do processo de Alfabetização Científica nas exposições em jardins botânicos e museus de ciências. Dessa forma, acreditamos poder contribuir com as reflexões desempenhadas pela educação não formal no empenho que o ensino de Ciências promova a Alfabetização Científica.

\subsection{Objetivos}

Considerando que os museus podem promover processos de $\mathrm{AC}$ e com o intuito de estudar o papel do uso de materiais didáticos de apoio à visita em museus para este processo, o presente trabalho tem como objetivos:

\section{Objetivo Geral}

Analisar o processo de Alfabetização Científica em visitas de famílias ao Jardim Botânico (JB) de São Paulo (SP) a partir do uso de um roteiro elaborado sob a perspectiva da Alfabetização Científica (AC) em museus.

Compreender o papel do roteiro de visita a Trilha da Nascente do JB de SP como estratégia para a promoção do processo de Alfabetização Científica junto a famílias que visitam este local.

\section{Objetivos Específicos}

Desenvolver um roteiro de visita a uma exposição do JB que favoreça o processo de desenvolvimento de $\mathrm{AC}$ nos visitantes

Aplicar o roteiro com visitantes do JB, analisando o potencial do uso dessa ferramenta no processo de Alfabetização Científica do público. 


\section{ALFABETIZAÇÃO CIENTÍFICA E MUSEU}

\subsection{Alfabetização Científica: Conceito}

As discussões em torno da Alfabetização Científica (AC) não são recentes e vêm ganhando espaço nos últimos anos no ensino e na divulgação da ciência. A preocupação com a formação do cidadão crítico com relação aos temas científicos e tecnológicos levou à discussão sobre o papel e as próprias metas do ensino de ciências (DEBOER, 2000).

O termo foi cunhado na década de 1950 e não é consensual até os dias de hoje. Vale, nesse sentido, destacar a pluralidade semântica exposta no trabalho de Sasseron e Carvalho (2011). Segundo as autoras, no ensino de Ciências é possível encontrar autores que utilizam a expressão "Letramento Científico", outros que adotam o termo "Alfabetização Científica" e também aqueles que usam a expressão "Enculturação Científica" na literatura brasileira. Todavia, o objetivo e as preocupações que permeiam o ensino de ciências são comuns aos três termos: "a formação cidadã dos estudantes para o domínio e uso dos conhecimentos científicos e seus desdobramentos nas mais diferentes esferas de sua vida" (SASSERON; CARVALHO, 2011, p.60).

Entretanto, o mundo social cada vez mais acelerado tecnologicamente nos impõe a necessidade de uma compreensão de seus processos. Sobretudo, os impactos causados pela expansão do capital, cujos avanços tecnológicos trazem não apenas possibilidades positivas, do campo produtivo ao social, mas também efeitos colaterais - como a poluição, o aquecimento do globo terrestre - e, desde fins do século $\mathrm{XX}$, a necessidade imperativa de pensar uma sociedade sustentável. Neste sentido, a "Declaração de Budapeste", aprovada durante a Conferência Mundial sobre a Ciência - "Ciência para o Século XXI: Um Novo Compromisso", em 1999, realizada pela Organização das Nações Unidas para a Educação, a Ciência e a Cultura (Unesco), é um marco fundamental que estabeleceu, no tocante à educação e conscientização, sobretudo, a necessidade e importância do conhecimento científico e o esclarecimento das questões socioambientais para o desenvolvimento de um futuro sustentável.

Com a perspectiva de incrementar a discussão no ensino de ciências, destacamos as diferenças entre alfabetização e letramento propostas Krasilchik e Marandino no campo da linguagem:

Ser "alfabetizado" é saber ler e escrever, mas ser "letrado" é viver na condição ou estado de quem sabe ler e escrever, ou seja, cultivando e exercendo as práticas sociais que usam a escrita. Se ampliarmos essa definição de letramento para o âmbito da ciência, entendemos que ser 
letrado cientificamente significa não só saber ler e escrever (KRASILCHIK; MARANDINO, 2004, p. 22).

Nesse sentido, a expansão do significado da expressão "ser alfabetizado" - que envolve apenas as capacidades de leitura e escrita - pode assumir o caráter do outro significado de Alfabetização Científica proposto por Miller (1983, p. 30, apud LORENZETTI; DELIZOICOV, 2001, p. 3) em que há "capacidade de ler, compreender e expressar opinião sobre assuntos de caráter científico".

[...] quando se fala em alfabetização, normalmente não se percebe que a expressão ser alfabetizado apresenta dois significados diferentes: um, mais denso, estabelece uma relação com a cultura, a erudição. Por conseguinte, o indivíduo alfabetizado aquele que é culto, erudito, ilustrado. $\mathrm{O}$ outro fica reduzido à capacidade de ler e escrever (MILLER,1983, p. 29. apud LORENZETTI; DELIZOICOV, 2001).

Pensando nisso, o termo "Alfabetização Científica" utilizado no presente trabalho vai de encontro à ideia de alfabetização exposta por Paulo Freire (1980, p.111):

[...] a alfabetização é mais que o simples domínio psicológico e mecânico de técnicas de escrever e de ler. É o domínio destas técnicas em termos conscientes. [...] Implica numa auto-formação de que possa resultar uma postura interferente do homem sobre seu contexto".

É também a partir de Paulo Freire que Sasseron estabelece a defesa do conceito de Alfabetização Científica, diante de sua concepção que a alfabetização é um processo que permite a construção de saberes através do estabelecimento de conexões entre a vivência pessoal e a linguagem. (SASSERON, 2008, p. 12).

Em 2011, Sasseron e Carvalho publicam uma revisão bibliográfica sobre o conceito de Alfabetização Científica na revista Investigações em Ensino de Ciências, na qual são apresentadas algumas das habilidades que Gérard Fourez considera necessárias para a classificação de uma pessoa como alfabetizada cientificamente.

Uma pessoa alfabetizada científica e tecnologicamente utiliza os conceitos científicos e é capaz de integrar valores, e sabe fazer por tomar decisões responsáveis no dia a dia; compreende que a sociedade exerce controle sobre as ciências e as tecnologias, bem como as ciências e as tecnologias refletem a sociedade; compreende que a sociedade exerce controle sobre as ciências e as tecnologias por meio do viés das subvenções que a elas concede; reconhece também os limites da utilidade das ciências e das tecnologias para o progresso do bem-estar humano; conhece os principais conceitos, hipóteses e teorias científicas e é capaz de aplicá-los; aprecia as ciências e as tecnologias pela estimulação intelectual que elas suscitam; faz a distinção entre os resultados científicos e a opinião pessoal; reconhece a origem da ciência e compreende que o saber científico é provisório, e sujeito a mudanças 
a depender do acúmulo de resultados; compreende as aplicações das tecnologias e as decisões implicadas nestas utilizações; possua suficientes saber e experiência para apreciar o valor da pesquisa e do desenvolvimento tecnológico; conheça as fontes válidas de informação científica e tecnológica e recorra a elas quando diante de situações de tomada de decisões; uma certa compreensão da maneira como as ciências e as tecnologias foram produzidas ao longo da história (GÉRARD FOUREZ, 1994, apud SASSERON; CARVALHO, 2011, p. 67-70).

Finalmente, devemos compreender que apesar de inicialmente compreendida como um movimento voltado à formação de "cientistas", a Alfabetização Científica passou a ser pensada dentro de uma perspectiva de formação social (BYBEE, 1995; ROBERTS, 2007), sobretudo por que o ambiente escolar não pode ou deve ser compreendida como o único e preponderante espaço em que as informações e os fundamentos científicos são internalizados (LORENZETTI; DELIZOICOV, 2001).

A Alfabetização Científica deve ser entendida, portanto, como a apreensão de fundamentos e saberes que possam ser instrumentalizados na aprendizagem. Além disso, também deve estar relacionada à compreensão de uma visão observante, reflexiva e crítica que deve permitir estudantes, visitantes e o público, em geral, articularem informações e construírem sentido, transformando sua percepção sobre o mundo natural e sobre as intervenções humanas nesse. Na mesma linha de raciocínio das autoras e diante de tantas habilidades levantadas para considerar um indivíduo alfabetizado cientificamente, devemos encarar o desafio de refletir e planejar a Alfabetização Científica nos museus de ciências.

Nesta direção, nosso trabalho pretende verificar empiricamente tais conceitos e habilidades, tomando a posição inicial de que a educação não formal é fundamental para a construção do conhecimento científico, levando em conta os espaços não escolarizados, sobretudo museus e suas exposições, em que a Alfabetização Científica se realiza. Nesse sentido, discutiremos o papel da $\mathrm{AC}$ nos museus, para então, discutirmos o desenvolvimento de como nossa pesquisa particularmente atuou metodologicamente na verificação de seus indicadores.

\subsection{Alfabetização Científica nos Museus}

Para Bybee (1995) a Alfabetização Científica é um processo contínuo e que se dá no decorrer da vida do indivíduo. Nesse sentido, DeBoer (2000) sinaliza a importância da 
Alfabetização Científica em espaços além da escola ao afirmar que não há uma única maneira correta de ensinar ciência. Ademais, ainda segundo DeBoer, a ideia de Alfabetização Científica está primariamente voltada ao nível de compreensão científica existente na população adulta, que muda e cresce ao longo do tempo, e não ao que os alunos sabem quando estão na escola. Evidentemente, o conteúdo aprendido na escola certamente irá afetar as atitudes discentes em relação à ciência e o desejo de continuar a aprender no futuro. Para Bizerra (2009), os museus fazem parte da sociedade, integrandoa de maneira significativa, possuindo um papel educacional de reprodução do conhecimento humano e mediador da cultura, permitindo a disseminação de conteúdos através da exposição de seus temas e objetivos. Para a autora:

\begin{abstract}
Nesse sentido, o entendimento do caráter educativo como presente em todos os elementos constitutivos da cadeia operatória museal (que envolve, resumidamente, além da extroversão já citada, o planejamento organizacional e físico, a conservação de objetos, a documentação de informações e a avaliação processual), constitui-se como base para o desenvolvimento de atividades que apresentem um olhar diferenciado para a relação entre a sociedade e os artefatos mediadores da cultura (BIZERRA, 2009, P. 25).
\end{abstract}

Neste sentido, as reflexões de Cury (2009) podem ser adotadas para compreender o público como um agente ativo que reflete, interpreta, constrói significados, e não como um expectador que passivamente apreende um conteúdo transmitido verticalmente.

Estudos revelam que espaços de educação não formal podem contribuir para a ascensão da Alfabetização Científica da população (LEMKE, 2006; RENNIE, 2007; LUCAS, 1991; LAUGKSCH, 2000; PÉREZ; MOLINI, 2004; FEINSTEIN, 2011). E, nessa perspectiva, discussões sobre Alfabetização Científica têm sido direcionadas aos museus. Lorenzetti e Delizoicov (2001) reforçam essa ideia em espaços de educação não formal e referenciam Cobern (1995) para alegar que a Alfabetização Científica não é adquirida integralmente nas aulas de ciências. Segundo os autores:

Se a escola não pode proporcionar todas as informações científicas que os cidadãos necessitam, deverá, ao longo da escolarização, propiciar iniciativas para que os alunos saibam como e onde buscar os conhecimentos que necessitam para a sua vida diária. Os espaços não formais compreendidos como museu, zoológico, parques, fábricas, alguns programas de televisão, a Internet, entre outros, além daqueles formais, tais como bibliotecas escolares e públicas, constituem fontes que podem promover uma ampliação do conhecimento dos educandos (LORENZETTI; DELIZOICOV, 2001, p.9). 
Para Cazelli e Franco (2001, p.12) a apreensão de conhecimentos e habilidades para o exercício de práticas sociais de leitura e escrita que circulam na sociedade é um processo contínuo "que acontece não somente na escola (educação formal), mas também por meio da interação com pares, colegas, amplas comunidades e com os diversos espaços de caráter cultural disponíveis no contexto social (educação não formal) ". Moreira (2013, p.39) fomenta essa asserção ao dizer que hoje em dia tem-se valorizado a educação na formação de pessoas para além do ambiente escolar "tanto no intuito de complementar quanto no de ampliar a educação escolar”.

Além disso, Cazelli e Franco (2001, p.11) discorrem sobre as novas exigências no campo da educação em um cenário de rápidas mudanças - que tem efeitos em diversos aspectos do dia-a-dia -, envolvido pelo desenvolvimento da ciência e da tecnologia, e, por conseguinte, a modernização da sociedade que redefinem o tempo e o espaço social.

Correlato a esse panorama, Cazeli et al. (1999) apontam que os museus, ao se preocuparem com a melhoria do ensino de ciências, "foram eleitos para proporcionar à sociedade as informações científicas para compreender o mundo em mudança". Evidências da ênfase dada ao papel do setor educativo nos museus de ciências nos últimos anos e como essas instituições têm se comprometido com a educação no decorrer da vida das pessoas são apontadas no artigo de Gruzman e Siqueira (2007, p.402). As autoras ressaltam a procura no aprimoramento do processo comunicativo para com o público visitante dessas instituições, "no intuito de romper com modelos tradicionais de transmissão de conhecimento".

Atkins et al. (2008) levantam referências sobre pesquisas que buscam compreender o impacto das interações sociais para a aprendizagem em ambientes de educação não formal e, para tanto, citam pesquisadores como Borun, Gelman, Chambers e Cleghorn, além de Dierking e Falk ao discorrerem sobre investigações que versam sobre a forma com a qual grupos estruturam diálogos e contribuem para atividades nesses espaços. Especificamente, Falk e Dierking (2012) formulam o conceito de "free-choice learning" (aprendizagem de livre escolha), para a compreensão de aprendizagens fora do espaço escolar, como em museus, mídia e outros espaços. Dentro dessa perspectiva, os conhecimentos são formulados, refletidos e construídos a partir de vários meios que transcendem a escola, e cujo agente do aprendizado é o personagem central que se apropria, interpreta, reinterpreta e cria associações a partir destes vários polos de referência, produzindo um repertório próprio, individual, mesmo que socialmente compartilhado. Também para Dierking, as exposições que ofertam conteúdos científicos 
favorecem sua apreensão graças à diversidade de estímulos multissensoriais, tridimensionais, interativas e afetivas (DIERKING, 2002).

Nesse mesmo sentido, os autores Atkins et al. mencionam os trabalhos de Matusov e Rogoff (1995), McManus (1989) e Paris (1997) para reforçar que o museu, em especial, é um local propício para motivar, desenvolver atividades e estabelecer diálogos e interações entre grupos. Também relatam que pesquisadores em museus começaram a consolidar uma literatura voltada para a compreensão de como grupos interagem em museus (DIAMOND, 1986; ELLENBOGEN, 2002; HILKE, 1987) e a pensar como melhor estruturar exposições que influenciem a extensão e a natureza dessas interações (ASH, 2013; BORUN; DRISTAS, 1997; CROWLEY; CALLANAN, 1998; MCMANUS, 1989).

Como podemos observar, existe uma vasta literatura que discute o potencial dos museus na promoção da AC. Um roteiro não escolarizado, a interação entre grupos, exposições que motivam os visitantes e a concretude dos elementos expostos demonstram esse potencial. Isso permite uma articulação direta entre conhecimento, aprendizado e observado. Tomando em conta a perspectiva de que o público constrói sua visão e compreensão acerca dos conteúdos em função das várias referências que se estabelecem no cotidiano, os museus cumprem um papel de qualitativamente articular exposição e conhecimento científico, de maneira recontextualizada (MARANDINO, 2004b). Nesse sentido, o trabalho de produção do discurso expositivo nos museus feito por educadores e especialistas potencializa os fatores estéticos e emocionais dos visitantes, além de instrumentalizá-los diante da existência de ferramentas que conectem os diferentes saberes, inclusive os prévios à experiência da visita ao museu.

Em nossa pesquisa, particularmente, procuraremos estudar o potencial de um material de apoio à visita - o roteiro - em estimular diálogos e interações em grupos na perspectiva da $\mathrm{AC}$ e, dessa forma, contribuir para compreensão do papel dos museus, em especial dos jardins botânicos para a promoção deste processo.

\subsection{Alfabetização Científica em Jardins Botânicos}

De acordo com esse breve levantamento bibliográfico, há diversas possibilidades de abordagem da Alfabetização Científica, conceito este que tem ganhado força no cenário mundial atual. Nota-se, cada vez mais, a existência de projetos desenvolvidos com a intencionalidade de tornar os conhecimentos científicos mais acessíveis à 
população em geral, tendo em vista os avanços científico-tecnológicos atuais e a importância da maior participação em temas que envolvam impactos na sociedade.

Considerando a importância dos Jardins Botânicos para a educação não formal e pelo fato desses locais serem apontados como oportunos para a aprendizagem, ou seja, a compreensão de conceitos científicos e a ampliação do entendimento do processo de produção de conhecimento dentro de um contexto social, a visita roteirizada pode se constituir como coadjuvante do Jardim Botânico no processo educativo, à medida em que pode favorecer aos visitantes a melhor compreensão das relações entre ciência, sociedade e ambiente.

Clayton, Fraser e Saunders (2009), por sua vez, apontam que os espaços educacionais não formais são compreendidos como ambientes de lazer - e não de aprendizagem - por seus visitantes. Neste sentido, compreender museus, zoológicos, ou o próprio Jardim Botânico como educação não formal, só pode ter sentido sob um olhar que analisa a percepção dos visitantes sob uma ótica de compreensão casual.

Os Jardins Botânicos são definidos como "instituições que guardam coleções documentadas de plantas vivas, visando à pesquisa científica, à conservação, à exibição e à educação" (WYSE-JACKSON, 1999 apud CERATI, 2014) e se propõem a difundir os conceitos científicos de maneira participativa, acessível e recreativa à população. Por isso, são apontados como "instituições seculares, reconhecidas como importantes centros geradores de conhecimento científico" (CERATI, 2014).

Para Bye (1994), o primeiro jardim botânico ocidental, criado com o objetivo de manter coleções de plantas para estudo e ensino, foi o Jardim de Teofrasto, criado por volta de 370-285 a.C., em Atenas, na Grécia. Teofrasto, discípulo de Aristóteles, foi o mais importante botânico da Antiguidade e se supõe que seu jardim botânico era parte de um liceu, onde realizava seus estudos e ensinava seus discípulos. Teofrasto, considerado o "pai da Botânica", escreveu De historia plantarum e De causis plantarum, textos em que discorre sobre a história das plantas e os fatores que afetam seu crescimento (FELIPPE; ZAIDAN, 2008).

O registro do primeiro jardim botânico moderno a se estabelecer na Europa foi o Jardim Botânico de Pisa, na Itália, fundado em 1543 por Luca Ghini e ligado à universidade local. Em seguida, foram estabelecidos, ainda na Itália, o Jardim Botânico de Pádua e o Jardim Botânico de Florença, ambos em 1545, e o Jardim Botânico de Bologna, em 1547 (HEYWOOD, 1987; BYE, 1994). Esses jardins caracterizavam-se por serem instituições de caráter médico e farmacêutico com o objetivo de cultivar plantas 
medicinais e de fornecer espécimes vivos para a produção de fármacos, para serem administrados pelos estudantes de medicina.

Com o avanço da taxonomia, os jardins botânicos europeus passaram a dedicarse profundamente ao estudo científico dos vegetais baseado na classificação lineana, além de se dedicarem à aclimatação de plantas.

Observa-se, então, que houve uma mudança nas funções desenvolvidas nos jardins botânicos. $\mathrm{O}$ estudo das plantas medicinais, de interesse econômico, e sua introdução na agricultura foram deixados em segundo plano, passando a ser atribuições de instituições especializadas, como hortos. Essa mudança acarreta uma cisão entre a ciência pura e a aplicada, tornando os jardins botânicos europeus claramente dedicados à primeira. Já os jardins botânicos que se estabeleceram nos trópicos tinham como objetivo principal a introdução de novas plantas para o cultivo. Considerados instrumento de expansão colonial, foram responsáveis pela transferência de germoplasma de uma parte do mundo para outra (HEYWOOD, 1987).

No território hoje pertencente ao Brasil, a primeira iniciativa de se estabelecer um jardim botânico foi de Maurício de Nassau, em Recife. Poucos registros são encontrados sobre a existência desse jardim, que funcionou de 1637 a 1644.

O primeiro jardim botânico da América portuguesa foi fundado em 1798, em Belém, recebendo o nome de Horto Botânico do Pará (HOEHNE; KUHLMANN; HANDRO, 1941), e tinha como objetivo o cultivo de especiarias orientais. Segundo Felippe e Zaidan (2008), o Jardim Botânico de Grão Pará, como também era conhecido, tentou organizar cientificamente sua coleção e dar início ao estudo da botânica, mas foi desativado em 1870.

Os resultados desse horto botânico favoreceram à expansão do número de Jardins Botânicos em território luso-americano. Por isso, logo após à chegada da Família Real, em 1808, foram criados, ainda em 1808, o Jardim Botânico do Rio de Janeiro, além do Jardim Botânico de Olinda (PE), em 1811. A expansão continuou após o grito do Ipiranga, já que em 1825 foram criados o Jardim Botânico de Ouro Preto (MG) e o Jardim Botânico de São Paulo (SP) (SEGAWA, 1996). Desses primeiros jardins, os que se mantêm até hoje são o Jardim Botânico do Rio de Janeiro e o Jardim Botânico de São Paulo, apesar desse último não estar mais em seu local de origem.

O Jardim Botânico do Rio de Janeiro foi o que recebeu atenção especial do príncipe regente D. João VI. Criado para ser um jardim de aclimatação, destinado ao cultivo das especiarias vindas das Índias Orientais, recebeu o nome de Real Horto. As 
primeiras plantas ali introduzidas foram conseguidas por tripulantes de uma fragata que se dirigia ao Brasil. Esses tripulantes foram capturados pelos franceses e ficaram numa prisão, onde havia um jardim com muitas especiarias. Um dos prisioneiros conseguiu fugir levando consigo certo número de plantas. Então, embarcou para o Brasil e, aqui chegando, ofereceu-as em troca de liberdade a D. João VI, que prontamente as introduziu no Real Horto Botânico (SIQUEIRA, 1998). Durante o governo de D. João VI, este jardim era privado. No entanto, no período de D. Pedro I, foi aberto ao público e, aos poucos, se transformou em jardim botânico, deixando de ser um local de aclimatação empírica para realizar trabalhos de experimentação, estudo e organização científica.

Na década de 1920, os jardins botânicos eram definidos como instituições que tinham como objetivo desenvolver ciência e instruir o público. Hoehne (1923) classificou os jardins botânicos em gerais e locais. O primeiro para abrigar plantas de diversas zonas geográficas, provenientes dos diferentes continentes, agrupadas harmoniosamente para que o visitante pudesse ter noção da flora de cada região do mundo. O segundo tipo abrigava plantas regionais com intuito de divulgar a composição vegetal da região onde o jardim botânico estivesse inserido, devendo, por isso, evitar plantas introduzidas.

As características intrínsecas do jardim botânico, bem como a diversidade de recursos naturais que o compõem, podem não apenas favorecer atividades que visem aguçar a curiosidade, como também estimular o aprendizado em família por meio da utilização de recursos didáticos. Compreendemos, neste sentido, os jardins botânicos como espaços que podem ser apreendidos dentro da lógica da educação não formal, uma vez que oferecem conteúdos e saberes não escolarizados, muitas vezes, não formatados e formalizados, mas cuja exposição, seja ela refletida ou não, compõe uma série de elementos a que o público, assim como em um museu tradicional, apreende e constrói elos cognitivos com informações e saberes prévios constituídos na vivência cotidiana.

Pensando nisso acreditamos que desenvolver materiais didáticos para esses espaços pode estimular o diálogo, a interação dos visitantes com o meio e contribuir para a Alfabetização Científica do público, propiciando bases para que os cidadãos possam agir ativamente na sociedade, criticando e transformando sua forma de ver o mundo.

\subsection{Alfabetização Científica em Materiais Didáticos}

Em nosso trabalho pretendemos investigar o potencial de um recurso didático para a promoção da Alfabetização Científica, revelando como se dá o processo de elaboração deste material e quais seus efeitos ao ser aplicado em visitantes de museus. Busca-se 
identificar elementos que forneçam evidências de que a AC esteja em desenvolvimento. Desse modo, interessam-nos analisar as interações e diálogos entre os pares e a exposição que as atividades propostas no material promovem e os dobramentos a elas associados.

Nosso pressuposto, dentro da perspectiva de Ensino das Ciências, é a de que os materiais educacionais necessitam estar articulados com outros conteúdos, e, portanto, potencializar as motivações estético-afetivas dos visitantes. Além disso, é imperativo que os materiais auxiliem a instrumentalização dos saberes e sua conjunta observação da exposição em direção da construção de um conhecimento científico que permita o desenvolvimento de habilidades, fundamentos e capacidade de conexão entre diversos elementos do mundo natural.

São diversas as estratégias educativas que intentam a divulgação científica, seja por meio de visitas guiadas ou por empréstimo de materiais (GIRAUDY; BOUILHET, 1990 apud GRUZMAN; SIQUEIRA, 2007, p. 405). Martins et al. (2013) destaca, dentre outras possibilidades: aulas, cursos, peças teatrais, atelier e reforça que as "ações educativas são estratégias que permitem ao visitante entrar em contato com a perspectiva daqueles que conceberam a exposição; mas também permitem construir seu próprios significados sobre aquilo que se vê" (MARTINS et al., 2013, p. 34).

Nesse momento, direcionamos o foco para as atividades educativas realizadas sem a presença de educadores e retomamos a ideia de que a educação em museus pode ser feita por meio de orientações ao visitante. Segundo Martins et al. são muitas as possibilidades de materiais impressos elaborados pelos setores educativos de exposições, como: guias expositivos, cadernos de atividades, materiais para o público escolar, cadernos de passatempos, etc. (MARTINS et al., 2013, p. 40).

Campos (2009, p.5) denomina como materiais didático-culturais aqueles que possuem "caráter instrutivo ou educativo voltados diretamente para o público visitante e também aqueles que expressam manifestações intelectuais ou artísticas, estando incluso entre esses os de divulgação científica, caderno de atividades para e professores, material institucional que divulga as ações dos museus e seu acervo".

Visto a possibilidade de uso de materiais didáticos como ferramenta de mediação entre o visitante e o conhecimento (Zuin et al, 2008), esse projeto busca compreender o papel das visitas roteirizadas aos Jardins Botânicos analisando o potencial do uso dessa ferramenta no processo de Alfabetização Científica do público. 
Para alcançar os objetivos aqui apresentados, há uma etapa que consiste na elaboração de um roteiro de visita. Dessa forma, realizamos um descritivo de como se deu o processo e quais foram reais atribuições dos elementos envolvidos.

Para que possamos iniciar a reflexão sobre o assunto em pauta, surgem os seguintes questionamentos: O que é um roteiro? Qual seu papel nas visitas? Que aspectos pedagógicos ele deve considerar?

Embora o termo "roteiro" seja frequentemente encontrado em trabalhos associados à prática educativa em museus (MARANDINO, 2011; VIEIRA; BIANCONI; DIAS, 2005; ALMEIDA, 1997), notam-se empregos distintos para a mesma palavra.

A ideia de "roteiro" ao qual nos referimos aqui em muito se assemelha com o conceito "guia educacional" proposto por Martins:

\begin{abstract}
se entregue antes da exposição, o objetivo do material [impresso] é ser uma espécie de guia educacional. Ele pode, dessa forma, propor atividades sobre a exposição, como perguntas sobre o que está sendo exposto, brincadeiras e jogos. Além disso pode também sugerir um percurso pela exposição, com paradas em vitrines e aparatos específicos, dentro da ideia de uma 'curadoria educacional'. Já quando os visitantes recebem o material após a visita, o objetivo é aprofundar e relembrar o que foi visto durante o percurso. O material, dessa forma, irá propor atividades de pesquisa, jogos e informações complementares à exposição" (MARTINS et al, 2013, p. 40).
\end{abstract}

Expandiremos, assim, o significado de "roteiro de visita" e o definiremos enquanto um material de orientação que auxilia o visitante a integrar e organizar objetos de referência, atrativos, equipamentos, serviços e infraestrutura de apoio para a reconhecimento e exploração de um determinado espaço. Tendo, assim, o potencial de conduzir e favorecer, direta ou indiretamente, a compreensão da informação exposta de forma mais precisa e com maior facilidade e pode ser capaz de auxiliar o visitante a se organizar antes e no momento da visita.

Desse modo, é nosso intuito produzir um roteiro que possa ao mesmo tempo promover aspectos da AC, a partir de uma perspectiva dialógica, buscando adequá-lo aos públicos visitantes de um Jardim Botânico. Com base nos objetivos já descritos, nos propomos investigar e responder às seguintes perguntas de pesquisa: 1) Que características podem ser incorporadas na produção de um roteiro de visita para tornálo estimulador e desencadeador de um processo de AC?;2) Serão as visitas roteirizadas boas estratégias para promover a AC dos visitantes nos JB's?; 3) Roteiros de visita calcados nos princípios da AC podem ser eficazes para promover este processo nos 
visitantes de JB's? Qual seu potencial e limitações?; 4) Como roteiros de visita elaborados a partir dos princípios da AC podem auxiliar as famílias que visitam o JB de SP a se inserir nesse processo? 


\section{METODOLOGIA}

A investigação aqui proposta se insere na perspectiva da pesquisa qualitativa, a qual envolve dados descritivos obtidos por meio da relação entre pesquisador e sujeitos ou situação estudada (LUDKE; ANDRÉ, 1986) e vem sendo utilizada nas investigações cujo foco é educação em museus (MARANDINO, 2005b; DIAMOND, 1999). Desse modo, consideramos adequada para a presente pesquisa uma vez que, por meio de indícios presentes na fala dos visitantes partícipes da atividade a ser analisada, pretende-se reunir informações acerca do potencial do uso do roteiro de visita para processo de Alfabetização Científica (AC).

A concepção desse material tomou por base a tese de Tania Cerati (2014), na qual a autora propõe indicadores e atributos de Alfabetização Científica para a análise deste processo nas exposições em jardins botânicos e museus de ciências. Para a análise do público, a autora se apoiou na proposta das habilidades investigativas desenvolvidas por Ash (1999) e, nesse cenário, analisou se a Trilha da Nascente abordava questões relacionadas à $\mathrm{AC}$, por exemplo, as maneiras pelas quais ocorria o seu processo junto aos visitantes.

Importante destacar que a produção do roteiro de visita foi o elemento central de inspiração desse trabalho de mestrado e nossa hipótese era de que, quando um material é concebido a partir de premissas teórico-metodológicas previamente definidas - no nosso caso os princípios da AC -, seria possível encontrar indícios destas premissas na experiência de visita dos sujeitos que o utiliza. Desse modo, este material educativo foi um meio, e não um fim, pelo qual se pretende promover a Alfabetização Científica dos visitantes.

Para o desenvolvimento da investigação selecionou-se duas unidades de análise: o roteiro de visita e a coleta de dados provenientes de sua aplicação junto ao público visitante.

A unidade voltada para a elaboração do roteiro é subdividida em duas fases: 1)

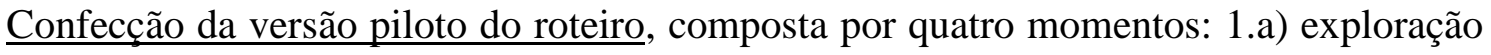
da trilha; 1.b) sistematização das informações coletadas, 1.c) elaboração da primeira versão ilustrada e da versão piloto; 1.d) encaminhamento do piloto do roteiro para análise, conforme descrito no item validação do roteiro. Nesse processo, foi realizado teste junto ao público, que corresponde a avaliação de caráter preliminar do material que, junto com 
as demais análises e avaliação da banca de qualificação, nos auxiliou a perceber os ajustes necessários para a versão final; 2) Produção da versão final do roteiro de visita.

A segunda unidade, que consiste na aplicação do roteiro, é composta por dois momentos: 1) Gravações de áudio e vídeo das conversas dos visitantes realizadas ao longo do percurso da exposição utilizando o roteiro de visita; e 2) Entrevista semiestruturada com os participantes ao término das atividades.

Os tópicos abaixo discorrem sobre as fontes de dados que compõem o espectro dessa pesquisa na segunda unidade de análise , a saber:

- Roteiro - caracterizado como o material educativo que norteou a visita das famílias, sua confecção foi baseada em indicadores de Alfabetização Científica. Buscou-se instigar habilidades investigativas por meio das atividades propostas. Ele é aqui apresentado como uma fonte primária de dados porque permite relacionar o tema e as categorias de análise de dados ao que foi observado em campo.

- Interações discursivas / Turnos de fala - Fonte principal de dados, trata-se do registro das falas dos visitantes no percurso da trilha utilizando o roteiro produzido. Fez-se a coleta audiovisual com uma filmadora e dois gravadores. Esse compêndio de fontes, conjuntamente com a transcrição das falas, serviu de base para a produção de um documento que permitiu um mapeamento das interações discursivas para a seleção dos turnos de falas que compuseram as Sequências de Diálogos Representativos (SDRs). Além do auxílio à transcrição, neste caso, o vídeo também foi utilizado para demarcar informações não ditas verbalmente pelos participantes.

- Entrevistas e fotografias - Estas fontes de registros foram aqui elencadas por assumir caráter complementar às interações ao longo do percurso. As falas oriundas da entrevista realizada após a visita foram utilizadas para esclarecer discussões presentes na visita roteirizada e as fotografias serviram de suporte para capturar as imagens dos elementos presentes no cenário da visita.

- Registro produzido - no roteiro havia um espaço destinado ao registro pelos visitantes das percepções mais marcantes da visita, por meio de um desenho. Esta etapa teve a finalidade de ampliar as possibilidades de identificar as percepções dos visitantes durante o uso do roteiro na Trilha. Este registro configura-se como uma interação comunicativa em potencial, já que os visitantes podem exprimir o que pensam em registro escrito. Trabalhos como o proposto por Sasseron e Carvalho (2010) destacam a importância dos registros em escrita e desenho em aulas de 
Ciências no processo de Alfabetização Científica dos educandos. Aqui, colocamos em evidência as considerações das autoras sobre os registros dos alunos que não se manifestaram oralmente. Dessa forma, consideramos que os registros e desenhos produzidos se apresentam como uma alternativa de expressão e uma forma de para relacionar e compartilhar o que sentiram e aprenderam.

Acreditamos que, ao relacionar os dados das interações discursivas com os registros dos visitantes no roteiro foi possível, além de evidenciar os momentos mais marcantes da visita roteirizada, identificar os indicadores de Alfabetização Científica, articulando o conhecimento teórico presente no roteiro, à realidade vivida e ao meio ambiente no qual os sujeitos estão inseridos.

\section{1.Área de estudo}

A área escolhida para o trabalho de pesquisa compreende a Trilha da Nascente do Riacho do Ipiranga, um espaço presente no Jardim Botânico de São Paulo, o qual possui uma área de 36 hectares localizada na zona sul da cidade e que está inserido no Parque Estadual das Fontes do Ipiranga (PEFI).

A Trilha é composta de vegetação remanescente de Mata Atlântica, preservando importantes espécies da flora e da fauna paulista. Está situada na parte final da área de visitação, a mil metros da entrada principal. Foi inaugurada em 2006 e recebe cerca de dez mil visitantes/mês ${ }^{2}$. A trilha é suspensa, com madeira de reflorestamento e acessível a pessoas com mobilidade reduzida. Segundo Cerati (2014) essa exposição tem como objetivos a inclusão social, a facilitação da pesquisa científica em uma unidade de conservação urbana, além de ser um espaço para abordar questões ambientais nas atividades educativas do programa de educação.

\footnotetext{
${ }^{2}$ Fonte: Núcleo de Pesquisa em Educação para Conservação do Instituto de Botânica.
} 
Figura 1: Vista da Entrada da Trilha

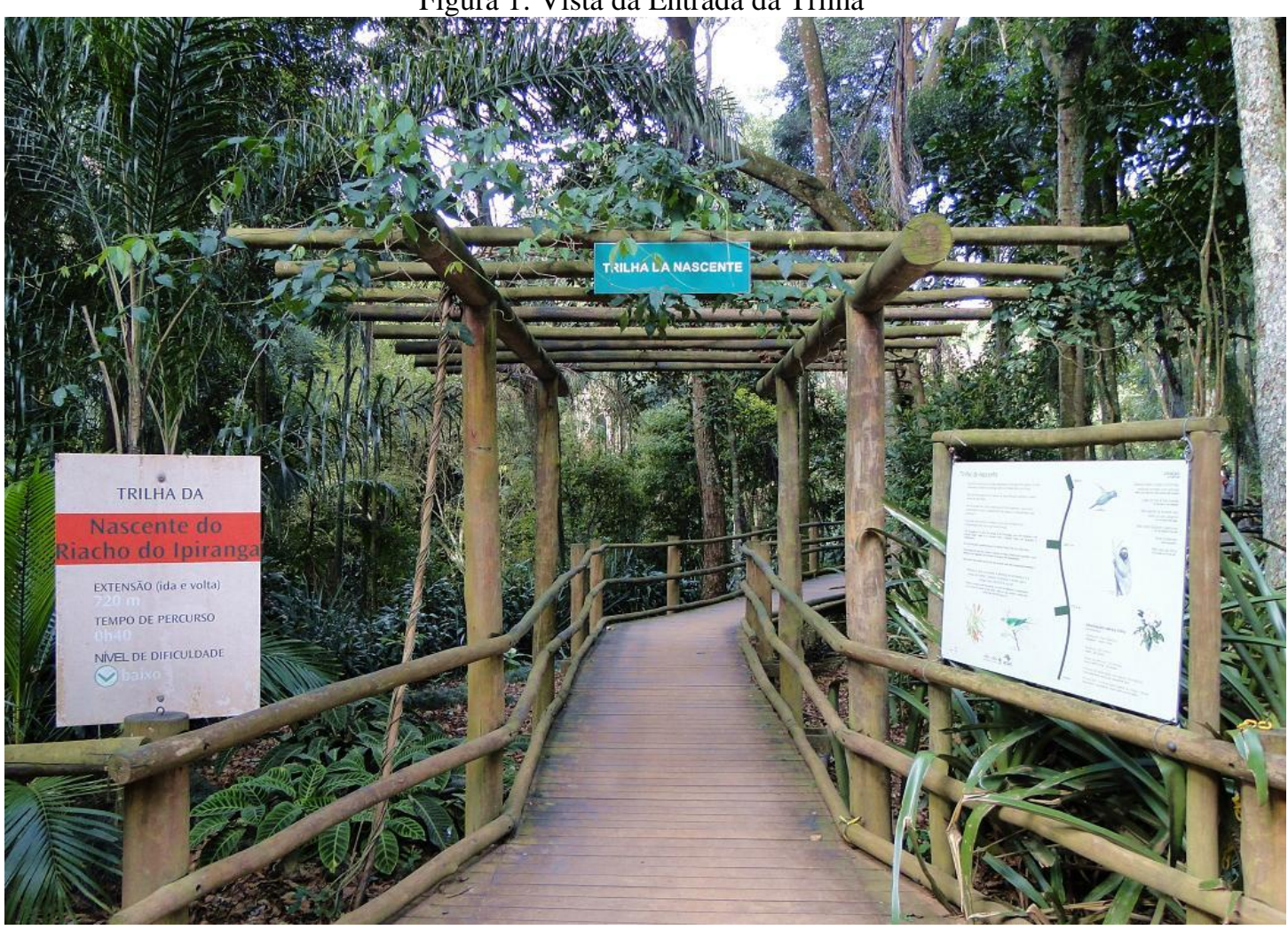

Fonte: autoria própria

A referida trilha possui 360 metros de comprimento com um percurso único; há três pontos de observação, localizados a 127 metros, 269 metros e 360 metros do início da trilha, que adentram a mata e permitem ao visitante melhor visualizar o córrego Pirarungáua, que possui o percurso paralelo à Trilha e nascente ao final dela.

Vale dizer que, além da coleção de plantas e da presença de fauna, a exposição possui cinco placas com informações técnico-científicas, a saber: Trilha da Nascente (Placa 1), Manejo (Placa 2), Macaco Bugio (Placa 3), Biodiversidade (Placa 4) e Nascente (Placa 5); 
Figura 2: Imagens das placas presentes na trilha

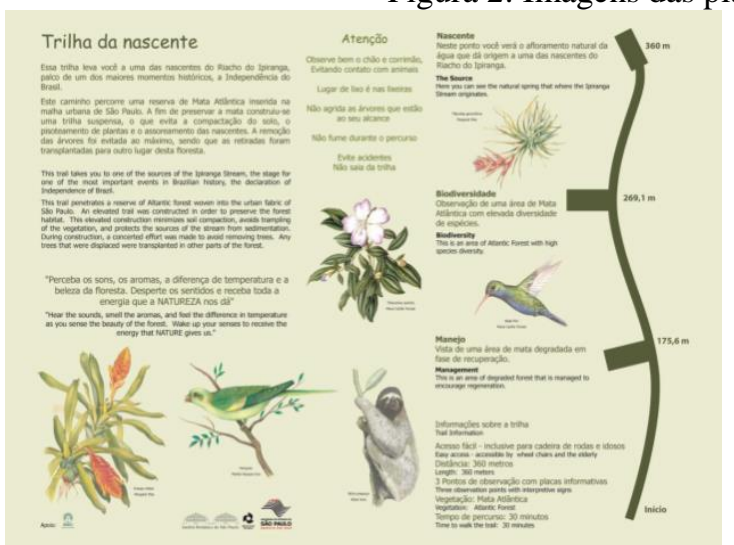

Placa 01. Trilha da Nascente

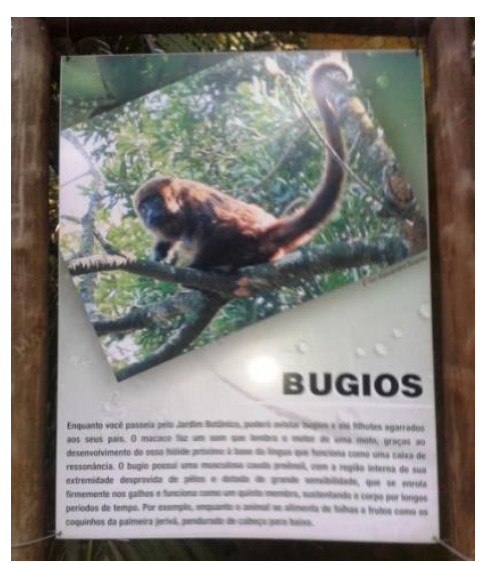

Placa 03. Bugios

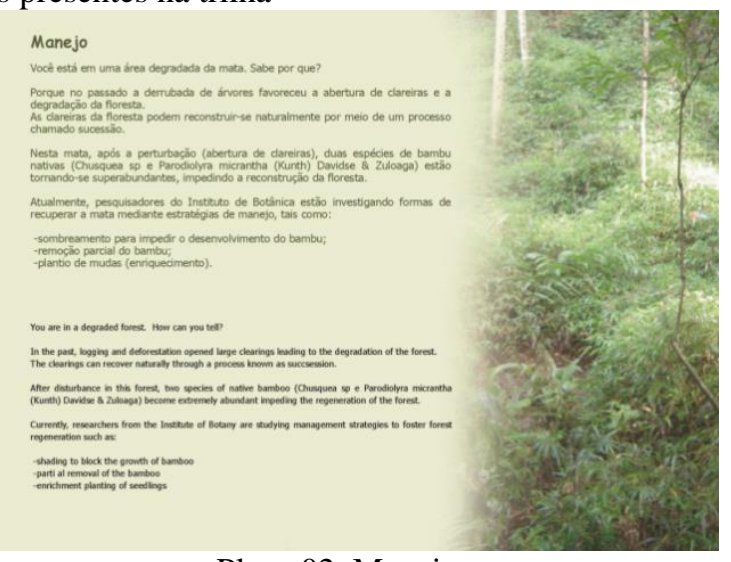

Placa 02. Manejo

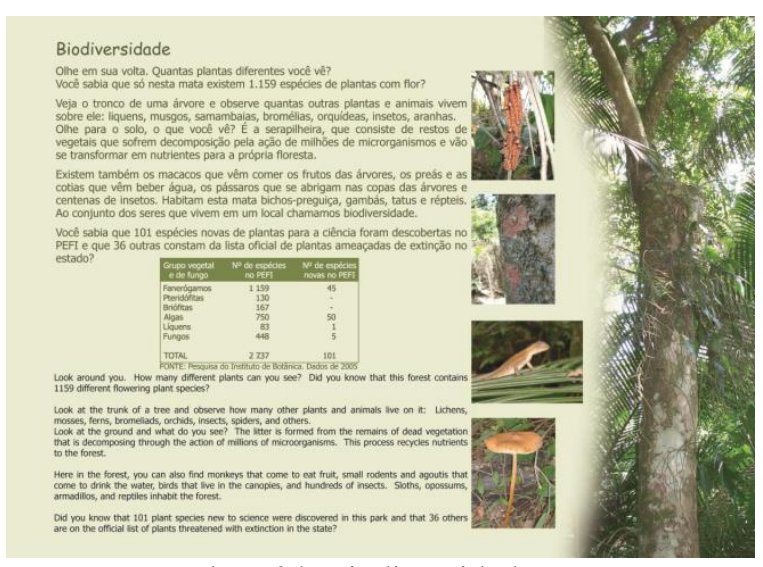

Placa 04. Biodiversidade

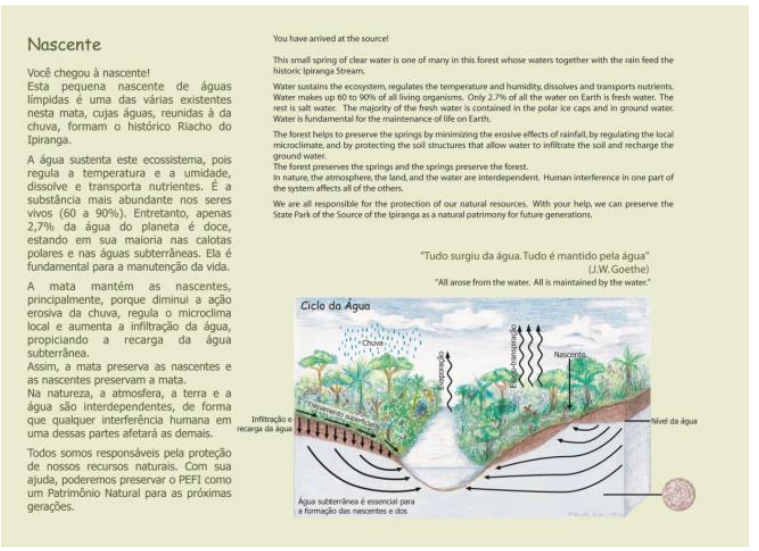

Placa 05. Nascente

Fonte (exceto placa $n^{\circ}$ 03: autoria própria): Guia Pedagógico do Jardim Botânico de São Paulo ${ }^{3}$

Para análise do discurso expositivo, Cerati (2014) em seu trabalho apresenta um esquema da Trilha da Nascente com os seus componentes: os textos (presentes nas placas), os objetos (representados pela vegetação existente ao longo do percurso) e o percurso da exposição (trajeto da trilha) e, para tanto, a divide em três trechos:

${ }^{3}$ Disponível em: http://www.ambiente.sp.gov.br/jardimbotanico/files/2013/08/guia-pedag\%C3\%B3gicodo-jardim-bot\%C3\%A2nico.pdf. 
Figura 3: Esquema da Trilha da Nascente

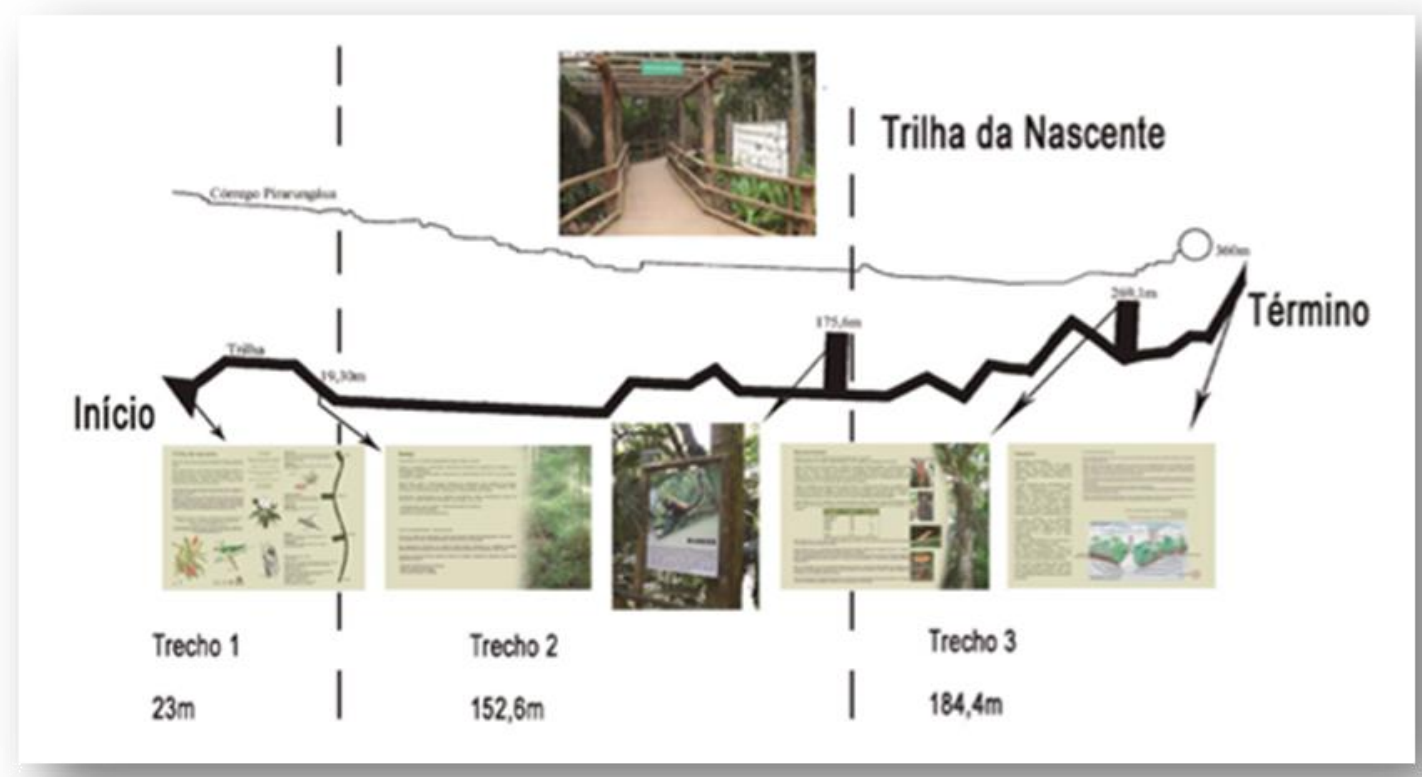

Fonte: Cerati, 2014

A autora revela e secciona essa representação de acordo com a mudança de paisagem observável ao longo do trajeto da trilha: no início da trilha há um pequeno trecho paisagístico onde a mata degradada se torna perceptível assim como a existência de clareiras. À medida que o caminho é percorrido, a mata se torna mais densa, há menor luminosidade e percebe-se maior umidade e menor temperatura.

Por não haver um marco que faz distinção entre os trechos 1, 2 e 3, e para evitar ideia de que há uma ordem que (de)limita a contemplação dos objetos do roteiro em um percurso único de observação e realização das atividades, a divisão por trechos não foi adotada nessa pesquisa. Entretanto, será possível notar que as ilustrações do plano de fundo do roteiro demonstram as nuances do gradiente de vegetação que vai tornando a mata mais densa no sentido entrada-nascente. Essas, entre outras observações descritas por Cerati (2014) foram consideradas para a produção do roteiro de visita usado em nossa pesquisa.

\subsection{Sujeitos}

O grupo amostral selecionado para esta investigação consiste em famílias. Além de tratar-se de um grupo espontâneo, que em geral possui um tempo maior para visita, a escolha desse público tem como referência o estudo de Cerati (2014) pois, segundo a 
autora, os grupos família e terceira idade representam $50 \%$ dos visitantes do Jardim Botânico de São Paulo.

Bizerra (2004) traz em sua tese de doutorado uma breve compilação da extensa literatura sobre os processos de aprendizagem desenvolvidos por grupos de famílias em museus. A autora reforça a ideia de que a pesquisa em aprendizagem familiar em museus surge como uma matriz disciplinar. Discorre, por isso, sobre estudos que visam compreender a forma com a qual famílias conversam sobre as exposições em análise, bem como outros que estabelecem metodologias de pesquisa acerca das relações entre a aprendizagem e os comportamentos observados, e - numa perspectiva sociocultural sobre investigações que abordam o papel dos museus na construção da identidade da família.

Embora não tenhamos como intuito versar especificamente sobre o processo de ensino-aprendizagem, estudar esse tipo de público é de interessante pois nos ajuda a compreender o potencial dos mecanismos interativos que os museus promovem com os grupos familiares e, em especial, o papel dos museus na promoção da AC para este público.

Desse modo, é nosso intuito produzir um roteiro que - a partir de uma perspectiva dialógica da educação em museus- possa promover aspectos da AC, buscando adequá-lo aos públicos visitantes de um Jardim Botânico. Esse roteiro será aplicado e avaliado com vistas a promover o processo de AC do público.

\subsection{O Instrumento de Pesquisa: O roteiro de visita "A Trilha da Nascente"}

Como vimos, a AC é um processo realizado ao longo da vida e que envolve várias dimensões da relação entre os indivíduos, a sociedade e o conhecimento científico. Buscando uma síntese dessas diferentes dimensões, Cerati (2014, p. 78-86) tomou por base a literatura nacional e internacional sobre este tema e, considerando ainda as especificidades do espaço por ela estudado, elaborou "indicadores e atributos para análise do processo de Alfabetização Científica nas exposições em jardins botânicos e museus de ciências". Além disso, a autora se apoiou para a análise do público na proposta das habilidades investigativas desenvolvida por Ash (1999). Com base nessas referências, Cerati (2014) analisou se a Trilha da Nascente abordava questões relacionadas à AC, buscando compreender a realização do processo de AC junto aos visitantes.

Consideramos, então, nesta pesquisa que os indicadores e atributos elaborados por Cerati (2014), e a ferramenta proposta por ela em seu estudo, são não somente 
consistentes, já que tomaram por base a vasta literatura sobre o tema, mas também adequados à análise dos processos de $\mathrm{AC}$ em espaços de educação não formal como os museus. A autora, ao construí-los, aprofundou os estudos sobre a AC nesses espaços educativos, o que possibilitou a inclusão das especificidades pedagógicas dos museus na descrição dos indicadores e de seus atributos. Por essa razão, os mesmos foram utilizados nesta pesquisa e estão sendo adotados em duas perspectivas: 1) como referência para a produção do roteiro de visita e 2) como categoria de análise para verificar se os sujeitos investigados percebem tais indicadores ao usar o roteiro durante a visita à Trilha da Nascente.

Os indicadores e atributos utilizados serão apresentados de forma sucinta. Também teceremos comentários sobre as habilidades investigativas que serão usadas para as análises. Em seguida, discorreremos sobre as etapas de criação do material e apresentaremos as atividades propostas no interior do roteiro segundo os mesmos indicadores e atributos de Alfabetização Científica (CERATI, 2014) e as Habilidades Investigativas (ASH, 1999).

1. INDICADOR CIENTÍFICO - possui relação com a apresentação de elementos intrínsecos da ciência, como processos e metodologias de produção do conhecimento científico, conhecimento de termos e conceitos vinculados a áreas específicas e produtos derivados dos avanços científicos. Para Cerati (2014, p.79), "uma exposição que pretende contribuir para a AC deve expressar a questão da natureza da ciência, fornecendo suporte para que o visitante construa seu conhecimento sobre assuntos científicos expostos".

Serão considerados, na produção do roteiro e na análise da fala dos participantes, a presença dos seguintes atributos do Indicador Científico:

1.a. Conceitos científicos e suas definiçõos.

1.b. Resultados da pesquisa científica.

1.c. Processo de produção de conhecimento científico. Apresentação de métodos e procedimentos da ciência, bem como a formulação de hipóteses, realização de testes, registros, publicações, entre outros aspectos.

1.d. Construção de conhecimento a partir da interação com o objeto/texto presente no discurso expositivo.

1.e. Papel do pesquisador no processo de produção do conhecimento.

1.f. Evolução da ciência, afirmando seu caráter questionável e inacabado. 
2. INDICADOR INSTITUCIONAL - explana informações sobre a instituição científica na qual a exposição foi concebida e/ou se faz presente, além do tipo de atividades científicas, sociais e culturais desenvolvidas pela referida instituição. Cerati (2014, p.80) afirma que o "indicador institucional, quando presente na exposição, permite que os visitantes reconheçam a função social da instituição, ampliem seu repertório relativo à cultura científica e compreendam os aspectos sociais, políticos e culturais que envolvem a produção da ciência".

Serão apreciados os seguintes atributos do Indicador Institucional:

2.a. Importância das coleções mantidas pela instituição.

2.b. Missão institucional como produtora e disseminadora de conhecimento científico.

2.c. Identificação das instituições envolvidas na produção e fomento à ciência.

2.d. Presença de elementos políticos e sociais ligados à instituição, que envolve o processo de produção e disseminação de conhecimento.

2.e. Contextualização da dimensão histórica da instituição e seu papel para o desenvolvimento científico.

3. INDICADOR INTERFACE SOCIAL - favorece a compreensão acerca das implicações da utilização do conhecimento científico na rotina e para a atual e próximas gerações. Cerati (2014, p.83) revela que "exposições que contemplam a interface social auxiliam o público a entender temas debatidos na atualidade e instrumentaliza os indivíduos para tomada de decisão na complexa sociedade contemporânea".

Para a confecção do roteiro e posterior análise das falas dos visitantes serão abalizados os atributos do Indicador Interface Social:

3.a Impactos positivos ou negativos da ciência na sociedade.

3.b Influência da sociedade na produção da ciência.

3.c Aplicação social do conhecimento científico, incluindo a conexão entre a temática expositiva e o cotidiano, possibilitando tecer relações entre a ciência e as questões sociais, históricas, políticas, econômicas e ambientais.

3.d Importância da ciência para a história da humanidade.

3.e Posicionamento do público diante dos resultados da ciência.

4. INDICADOR ESTÉTICO/AFETIVO - é expresso ao notar aspectos que causam emoções, observações, atitudes, sensações, valores e sentimentos na relação do público com o tema exposto. Cerati (2014, p.84) considera fundamental valorizar essa dimensão 
ao pensar o processo de $\mathrm{AC}$ em jardins botânicos, uma vez que estes são locais formados por paisagens naturais e planejadas para "promover o engajamento dos visitantes por meio da interação física, intelectual e emocional com os aparatos expostos".

No Indicador Estético/Afetivo, os atributos elencados são:

4.a Expressão de sentimentos a partir da interação com a exposição: apreço, prazer, repulsa, indignação, sensações, entre outras, em relação os fenômenos científicos e aos elementos naturais.

4.b Possibilidade de interação e de contemplação dos elementos da exposição.

4.c Motivação do público no envolvimento com o tema exposto.

Além dos indicadores de AC, iremos usar as habilidades investigativas propostas por Ash $(1999 ; 2003)$ tanto para elaboração do roteiro quanto para a análise das falas dos sujeitos, como fez Cerati (2014). Por um lado, acreditamos que construir o roteiro calcado em habilidades investigativas e indicadores de Alfabetização Científica pode auxiliar no direcionamento e manutenção de diálogos com argumentos mais sólidos, elaborados pela interação do visitante com o discurso expositivo. Esse aspecto favorece a perspectiva dialógica de interação entre conhecimento - objetos - textos - público almejada no roteiro.

Por outro lado, a análise dos diálogos das famílias tomará por base a técnica de Sequências de Diálogos Representativos (SDR), usadas por Doris Ash (2003) para a análise de trechos de diálogos entre visitantes de museus que contenham conexão com o tema abordado pela exposição. Em nossa pesquisa, a seleção de SDRs será contemplada e serão usados os mesmos critérios escolhidos por Cerati (2014) para a seleção de segmentos, como identificação de quem está falando, a existência de relação com o tema ou subtemas da exposição e as habilidades investigativas contidas nas falas dos integrantes família e relacionadas ao tema da exposição. Com isso buscamos avaliar a possibilidade de comparar os resultados por nós encontrados com aqueles de Cerati (2014) no que se refere ao potencial da Trilha da Nascente promover a AC.

Após a identificação dos SDRs, as falas do público serão analisadas também no que se refere às habilidades investigativas. São elas: observação - visualiza e examina objetos ou situações expostas; afirmação - sustenta, certifica-se ou corrobora com o outro; comparação - compara objetos diferentes buscando uma explicação; explicação Interpretação da exposição, esclarecimento; questionamentos - elaboração de perguntas, dúvidas, sobre o tema ou subtemas da exposição; emissão de opinião - manifesta uma 
ideia, emite um juízo sobre o tema exposto e conclusão - finalização do diálogo e sistematização das ideias principais (Ash, 1999).

\section{3.a. Processo de Produção do Roteiro de Visita: Construindo o roteiro "Trilha da Nascente"}

Nesta unidade, as atividades da pesquisa foram concentradas na produção e aplicação da versão piloto do roteiro. Elencamos abaixo as principais etapas desse processo:

\section{- Explorando a Trilha}

Inicialmente foram realizadas quatro visitas para observação e coleta de informações sobre elementos e temas existentes no espaço expositivo da Trilha passíveis de serem trabalhados no roteiro. Além disso foram feitos levantamentos prévios de informações históricas e de curiosidades sobre o local da Trilha em sites, trabalhos de pesquisa, entre outros. Abaixo um exemplo do primeiro registro feito em um caderno de campo:

Quadro 1 - Modelo de registro de observação da trilha

\section{$1^{\circ}$ REGISTRO DE OBSERVAÇÕES DA TRILHA DA NASCENTE DO RIACHO DO IPIRANGA}

Aspectos da trilha interessantes (pesquisa prévia):

- Importante ponto histórico, remetendo ao palco onde se deu a declaração da independência do Brasil;

- A trilha foi projetada de forma a não causar impactos negativos na mata, com uma parte em forma de deque de madeira feito com eucalipto de reflorestamento tratado e elevada em toda a sua extensão; últimos remanescentes de Mata Atlântica na Região Metropolitana de São Paulo.

- $\quad$ Primeira trilha projetada e construída no país obedecendo as normas de acessibilidade da ABNT - Associação Brasileira de Normas Técnicas - permitindo o acesso a pessoas portadoras de deficiências e de mobilidade reduzida.

Três trechos ${ }^{4}$ (observação geral da divisão adotada):

1) Trecho de mata em recuperação;

2) Área com elevada diversidade de espécies de plantas como samambaias, bromélias e orquídeas, além de árvores imensas (macacos, pássaros);

3) Uma das nascentes do histórico Riacho do Ipiranga.

O que me chamou atenção nessa visita (minhas anotações empíricas):

4 Como descrito anteriormente, a divisão da Trilha da Nascente em três trechos foi sugerida por Cerati (2014) por emblemar a mudança da paisagem e só será adotada nesse momento para melhor observar as nuances da paisagem ao longo do percurso e facilitar a localização espacial dos objetos na exposição. 


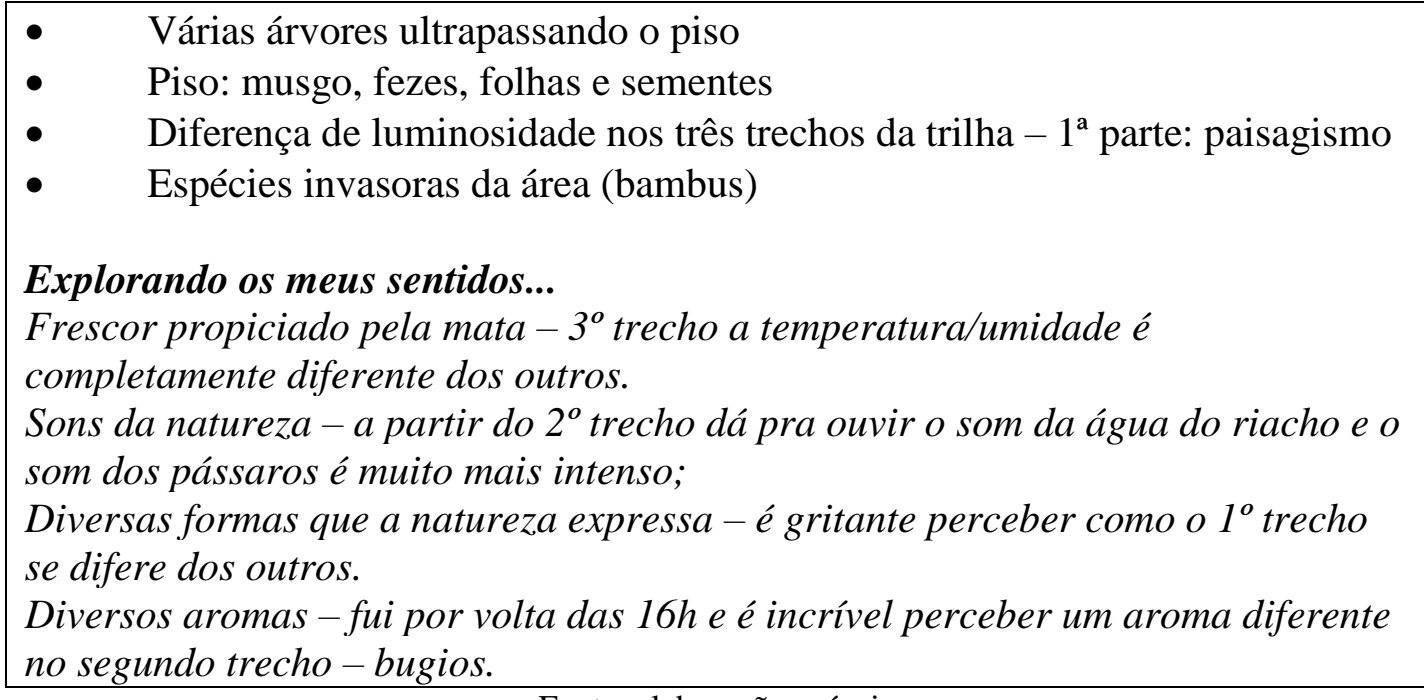

Fonte: elaboração própria

\section{- Sistematização das informações coletadas}

Para identificar elementos da Trilha que pudessem evidenciar os indicadores de $\mathrm{AC}$, estabeleceu-se critérios específicos para a coleta e organização das informações, além da elaboração de uma tabela com os elementos que posteriormente poderiam ser utilizados na confecção do roteiro. Os itens estabelecidos foram: trecho - (primeiro, segundo ou terceiro), divisão adotada conforme explicado anteriormente; referência espacial - referência do espaço para facilitar a localização do elemento em destaque; elemento em destaque - objeto da exposição que poderá ser utilizado como base para assuntos do roteiro; características ambientais - características do ambiente no qual aquele determinado objeto está inserido, tema- temáticas possíveis em que o referido elemento poderia estar inserido (acreditávamos que uma vez definido, o tema poderia ser escolhido de acordo com um padrão encontrado em diferentes elementos e servir como eixo norteador entre as atividades do material); interação - ação prevista para a realização de uma atividade no roteiro. Ainda nesta tabela, buscou-se identificar a relação entre os objetos selecionados com os Indicadores de Alfabetização Científica e seus respectivos Atributos. Para garantir espaço para descrição do indicador estético/afetivo, quando esse se fizesse presente, poderiam ser previstas ações como forma de estímulo a motivações; foram listadas ainda as habilidades investigativas que poderiam ser estimuladas a partir das atividades propostas no roteiro. Também foi colocado um campo para esboço do texto - a ideia era propor um texto que poderia constar no roteiro; caso necessário complementar o texto, haveria um campo para preenchimento de informações em box - 
"caixas" para informações extra; o campo Imagens era destinado à inserção ou ao código de imagens que seriam utilizadas como referência para ilustrar o elemento em destaque.

A seguir um dos exercícios realizados para exemplificar o preenchimento da tabela:

Quadro 2 - Modelo de sistematização dos dados

Trecho: $2^{\circ}$

Referência espacial: Árvore 3 - Cedro com bromélias, cacto, samambaias e liquens (repare que nesse caso o elemento em destaque é a própria referência espacial).

Elemento de destaque: Cedro com liquens e plantas epífitas.

Características ambientais: luminosidade variável ao longo do tronco

Tema: Diversidade vegetal; características dos liquens e suas adaptações ao ambiente

Interação: Tocar e descrever elementos como aparência, textura, coloração, odor, luminosidade

Indicadores de AC: Indicador Científico: 1a -Conceitos científicos e suas definições; 1d -Construção de conhecimento a partir da interação com o objeto/texto presente no discurso expositivo. Indicador estético afetivo: 4a - Expressão de sentimentos: apreço, prazer, repulsa, indignação, sensações, entre outras em relação os fenômenos científicos e aos elementos naturais; 4b -Possibilidade de interação e contemplação dos elementos da exposição.

Motivação (afetivo): Tocar o tronco; Expressar sensações e sentimentos

Habilidades investigativas: Observação, Reconhecimento, Explicação, Emissão de opinião,

Conclusão.

Esboço do texto do roteiro: O que são esses elementos verdes no tronco do cedro? Por que será que os liquens estão de um lado e não de outro do tronco?

Informação em box: Liquens = fungos + algas; associação mutualística; bioindicadores de poluição

Imagens: REF. img.006 [por exemplo]

Fonte: elaboração própria

A primeira versão da tabela apresentou maior ênfase de abordagens sobre os objetos expositivos relacionados ao indicador científico. Desse modo, novos elementos foram identificados na trilha que contemplassem os demais indicadores.

\section{- Elaboração da primeira versão ilustrada}

A primeira versão ilustrada do roteiro foi feita com o intuito de selecionar e adequar os conteúdos textuais, bem como começar a pensar no layout do material, sem que nesse momento houvesse preocupação com o rigor das imagens. Elas serviriam apenas como ícones entre um determinado ponto do trajeto da trilha e a legenda, localizada na parte superior ou inferior do material. Para as versões seguintes, optamos por utilizar imagens de cunho naturalista, para, ao mesmo tempo, promover a ludicidade a partir do uso de imagens e reforçar o rigor científico na representação dos elementos da 
trilha, aspecto importante da cultura científica. A seguir a primeira versão ilustrada ainda com os ícones:

Figura 4: Primeira versão ilustrada do roteiro [interior]

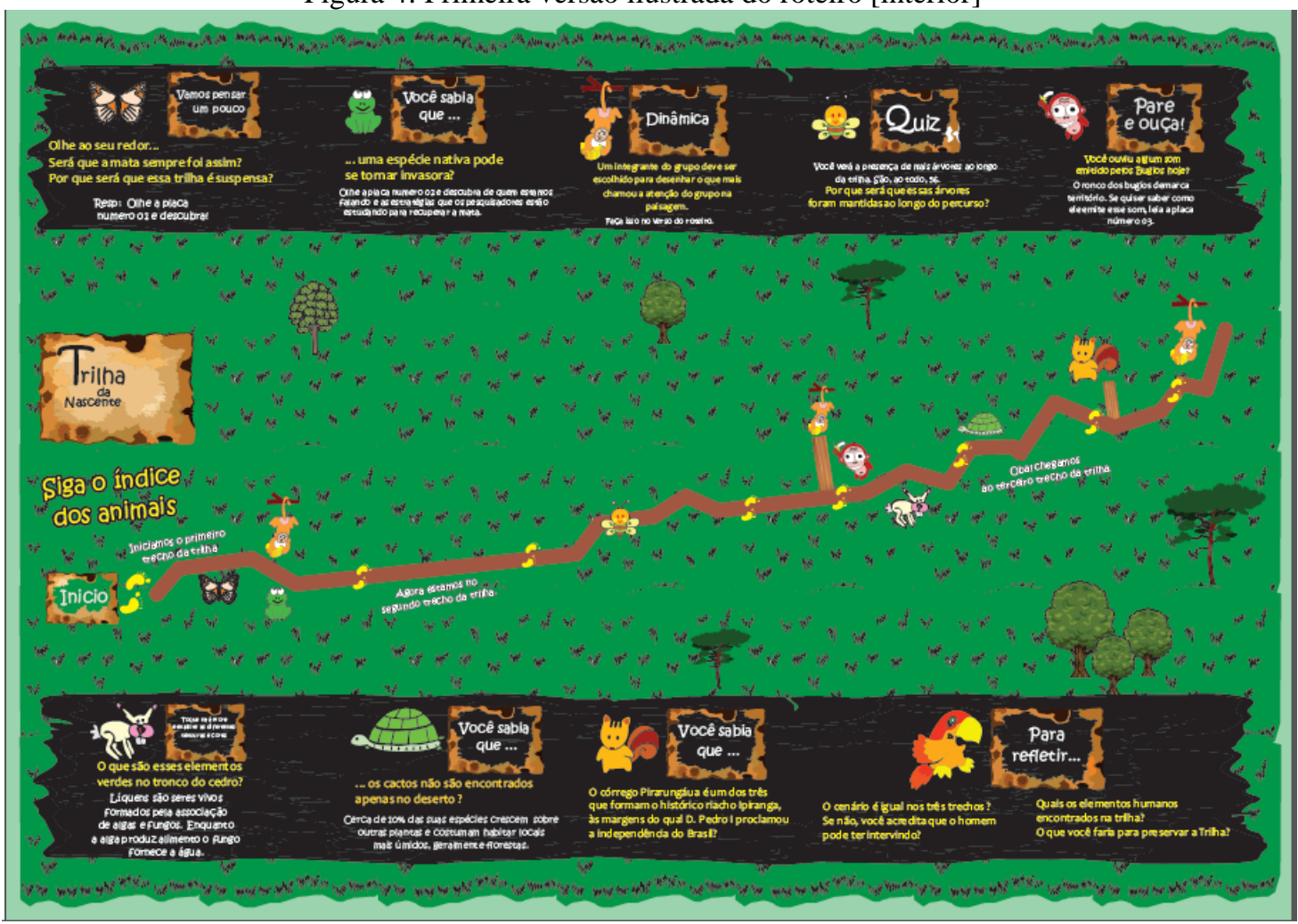

Fonte: elaboração própria 
Figura 5: Primeira versão ilustrada do roteiro [externo e abas]

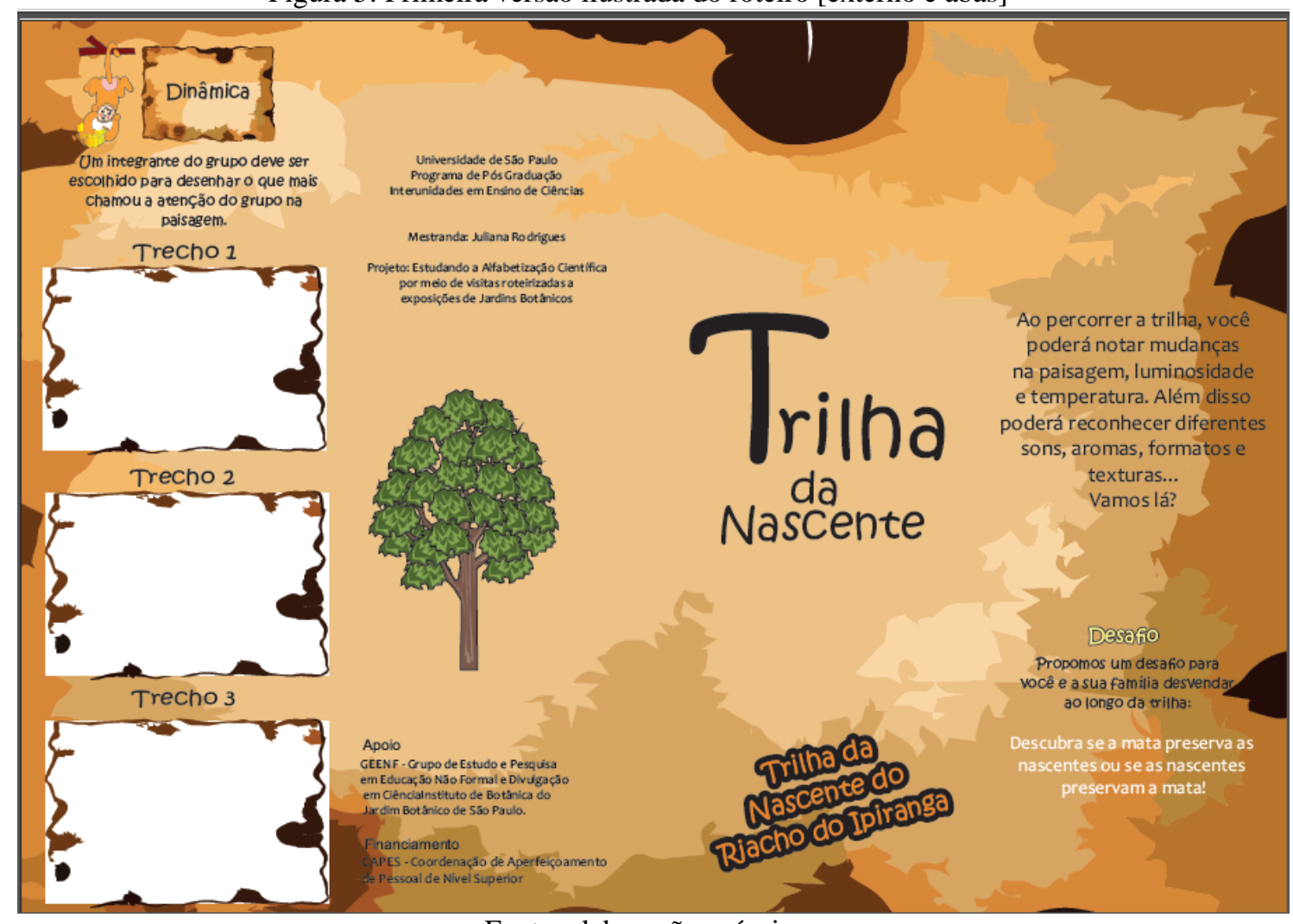

Fonte: elaboração própria

\section{- Elaboração da versão piloto e final do roteiro}

\section{a. Sobre o Layout}

Para a produção da versão preliminar contamos com o apoio do Instituto Nacional de Ciência e Tecnologia em Toxinas/INCTTOX/CNPq ${ }^{5}$, que financiou os custos no que concerne à ilustração e edição, bem como impressão do material. Por esta razão, houve a possibilidade de contratar uma ilustradora com formação em biologia que, em parceria com um designer gráfico, se tornou a responsável pela equipe de edição gráfica do roteiro.

${ }^{5}$ O INCTTOX (2009-2014), financiado pelo CNPq e FAPESP, baseia-se em estudos sobre toxinas, visando consolidar e ampliar grupos de competências científica/docente reconhecidas, abrangendo o imprescindível comprometimento socioeducativo, contemplar a inovação, o desenvolvimento de produtos e processos. Para tal possui várias ações em comunicação em ciências, por meio do subprograma "Ações em Saúde Núcleo de Difusão", com o papel de realizar a educação e difusão de conhecimentos. 
Figura 6: Primeira imagem enviada para aprovação do estilo de traço da ilustração

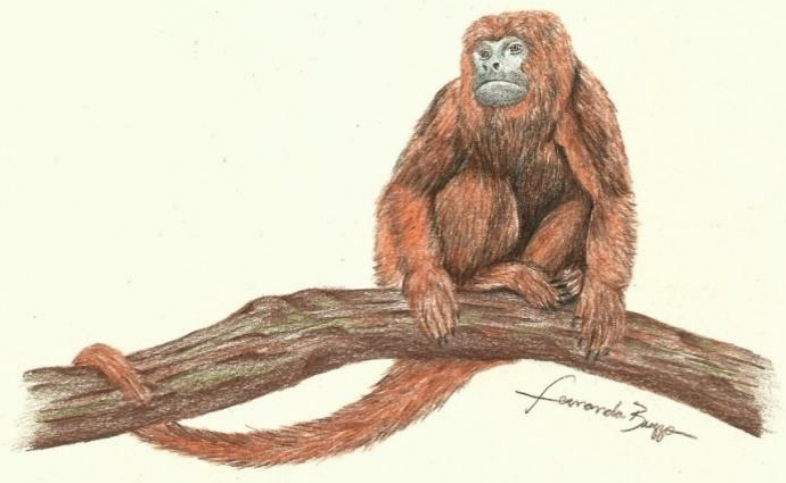

Fonte: Fernanda Buzzo

O trabalho de produção e edição do roteiro, com as diversas negociações entre a equipe de edição gráfica e a de conteúdo (formada pela pesquisadora e pela orientadora desta pesquisa), nos levou à percepção de que os textos propostos possuíam diferentes funções que implicavam diferentes ações da parte do visitante. Essa percepção nos levou a elaborar uma novo quadro com propostas para os diversos tipos de textos presentes no roteiro. O conteúdo do interior do roteiro bem como a função dos diferentes níveis de textos são apresentes a seguir:

Quadro 3 -Sistematização dos níveis de textos ${ }^{6}$ de acordo com a função

\begin{tabular}{|c|c|c|c|c|}
\hline Ícone & Subtítulo & $\begin{array}{c}\text { Texto complementar ao } \\
\text { subtítulo }\end{array}$ & Texto principal & Texto secundário \\
\hline Layout & letra maior & $\begin{array}{c}\text { mesma cor que o } \\
\text { subtítulo; letra média }\end{array}$ & letra média; cor diferenciada & letra menor \\
\hline Função & $\begin{array}{c}\text { Chamar a } \\
\text { atenção do } \\
\text { visitante }\end{array}$ & $\begin{array}{c}\text { Fornecer uma } \\
\text { informação (por vezes } \\
\text { destacada no subtítulo) } \\
\text { ou destacar ação do } \\
\text { visitante relacionada aos } \\
\text { sentidos (percepção). }\end{array}$ & $\begin{array}{l}\text { Comando para a atividade a ser } \\
\text { realizada. Engloba um } \\
\text { questionamento pontual } \\
\text { (conceito acessível na placa ou } \\
\text { informação será dada por nós) } \\
\text { e/ou reflexivo (que não } \\
\text { necessariamente terá uma } \\
\text { resposta). }\end{array}$ & $\begin{array}{c}\text { Comando para a leitura } \\
\text { de placas (dicas) ou } \\
\text { informações sobre as } \\
\text { ações, sejam elas os } \\
\text { questionamentos } \\
\text { pontuais. }\end{array}$ \\
\hline A & $\begin{array}{l}\text { Pare e } \\
\text { repare! }\end{array}$ & - & $\begin{array}{c}\text { Por que será que essa trilha é } \\
\text { suspensa? } \\
\text { E por que ela foi criada? }\end{array}$ & $\begin{array}{c}\text { Leia a } 1^{\text {a }} \text { placa e } \\
\text { descubra! }\end{array}$ \\
\hline B & $\begin{array}{c}\text { Você sabia } \\
\text { que... }\end{array}$ & $\begin{array}{l}\text {... nesta Trilha existem } \\
\text { espécies nativas que se } \\
\text { tornaram invasoras? }\end{array}$ & $\begin{array}{c}\text { Quais são elas? Quais as } \\
\text { estratégias dos pesquisadores } \\
\text { para recuperar a mata? }\end{array}$ & $\begin{array}{c}\text { Leia a } 2^{\mathrm{a}} \text { placa da trilha e } \\
\text { descubra! }\end{array}$ \\
\hline
\end{tabular}

\footnotetext{
${ }^{6}$ Textos da versão piloto do roteiro
} 


\begin{tabular}{|c|c|c|c|c|}
\hline $\mathrm{D}$ & $\begin{array}{l}\text { No meio do } \\
\text { caminho } \\
\text { tinha uma } \\
\text { árvore... } \\
\end{array}$ & $\begin{array}{l}\text { Foram mantidas em } \\
\text { torno de } 56 \text { árvores no } \\
\text { trajeto da trilha. }\end{array}$ & Por quê? Pense nisso! & \\
\hline $\mathrm{E}$ & $\begin{array}{l}\text { Pare, ouça } \\
\text { e saiba } \\
\text { mais! }\end{array}$ & $\begin{array}{l}\text { Em alguns momentos do } \\
\text { dia é possível ouvir o } \\
\text { ronco dos bugios. } \\
\text { Os bugios se alimentam } \\
\text { de frutos espalhando } \\
\text { sementes pela mata. }\end{array}$ & Você ouviu? & $\begin{array}{c}\text { Para saber mais, leia a } 3^{\mathrm{a}} \\
\text { placa. }\end{array}$ \\
\hline $\mathrm{F}$ & $\begin{array}{l}\text { Toque e } \\
\text { observe! }\end{array}$ & - & $\begin{array}{l}\text { O que são essas manchas } \\
\text { coloridas no tronco das árvores? }\end{array}$ & $\begin{array}{l}\text { Os liquens são interações } \\
\text { entre fungos e algas, } \\
\text { importantes porque } \\
\text { demonstram que a } \\
\text { qualidade do ar está boa! }\end{array}$ \\
\hline G & $\begin{array}{l}\text { Você sabia } \\
\text { que... }\end{array}$ & $\begin{array}{l}\text {... existem cactos na } \\
\text { mata? Nesta trilha } \\
\text { encontramos um } \\
\text { exemplar conhecido } \\
\text { popularmente como } \\
\text { "espaguete". }\end{array}$ & Como e onde este cacto vive? & $\begin{array}{c}\text { Ele vive em epifitismo, } \\
\text { em interação com outras } \\
\text { plantas sem prejudicá- } \\
\text { las. }\end{array}$ \\
\hline $\mathrm{H}$ & $\begin{array}{l}\text { Pare, } \\
\text { repare e } \\
\text { pense }\end{array}$ & - & $\begin{array}{c}\text { Como a mata e a nascente } \\
\text { colaboram para a preservação do } \\
\text { ambiente? }\end{array}$ & $\begin{array}{c}\text { Leia a } 5^{\mathrm{a}} \text { placa da trilha } \\
\text { para descobrir! }\end{array}$ \\
\hline I & $\begin{array}{l}\text { Hora de } \\
\text { refletir! }\end{array}$ & $\begin{array}{c}\text { O ser humano interage } \\
\text { de várias formas na } \\
\text { Trilha da Nascente... } \\
\text { Como? }\end{array}$ & $\begin{array}{l}\text { Agora reflita sobre o desafio } \\
\text { proposto no início do roteiro! }\end{array}$ & \\
\hline
\end{tabular}

Fonte: elaboração própria

O layout inicial da primeira versão do material foi mantido: duas lâminas de A3 (frente e verso), três dobras tipo janela e oito páginas. $\mathrm{O}$ esquema a seguir facilita a compreensão da referida dobra e a enumeração das partes do roteiro: 
Figura 7: Layout e partes do roteiro

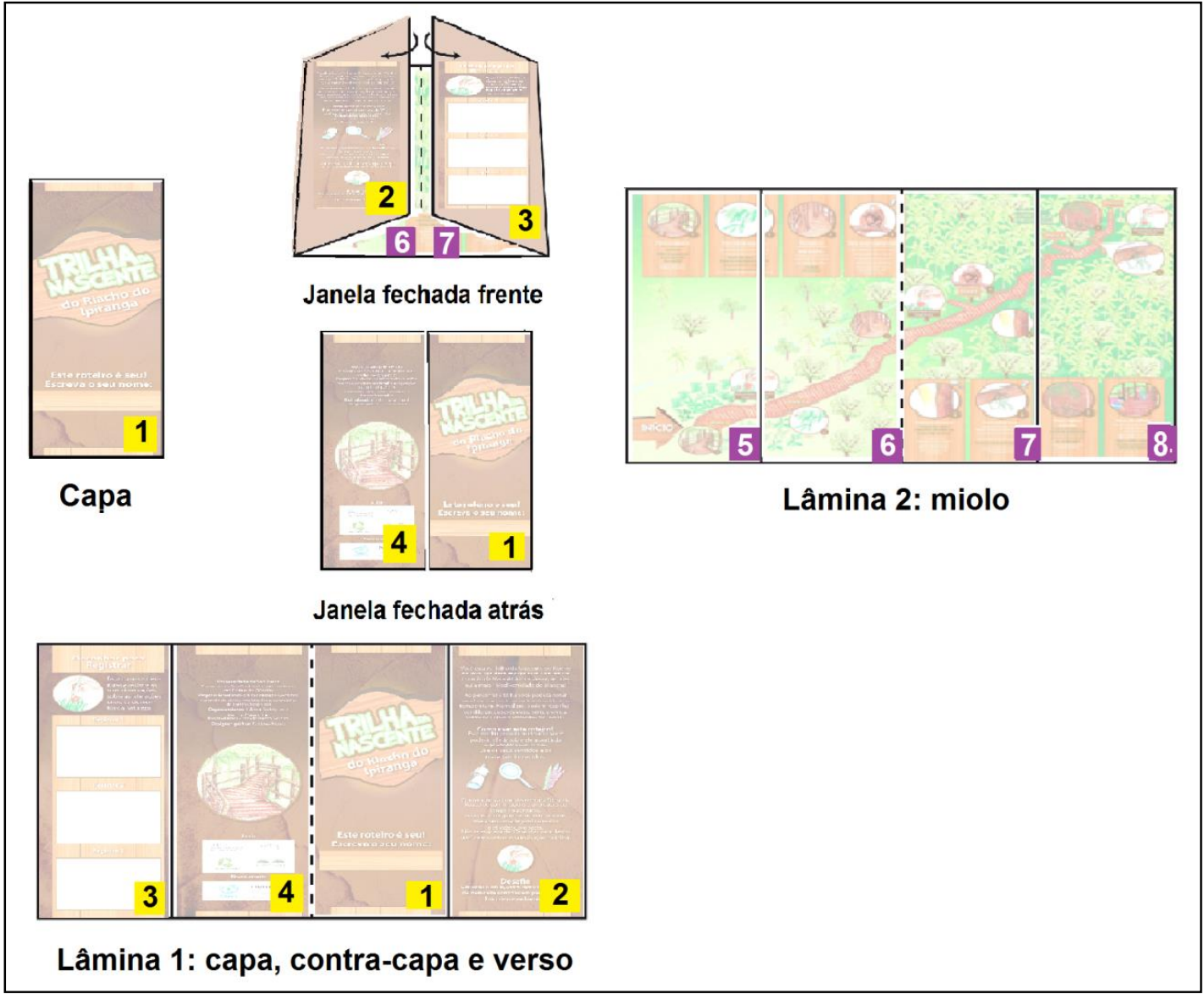

Fonte: elaboração própria

A lâmina com os números 1,2,3 e 4 [em amarelo] forma a frente e a com os números 5, 6, 7 e 8 [em lilás] forma o miolo.

\section{Capa [1]}

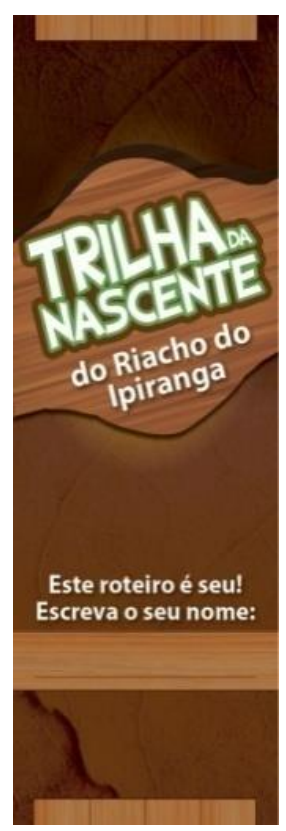

A capa do roteiro possui:

- Chamada com o nome da trilha ("Trilha da Nascente" em fonte maior);

- Subtítulo: "do Riacho do Ipiranga" (como complemento para a chamada);

- Campo para que o visitante possa colocar o nome.

\section{Texto impresso:}

"Trilha da Nascente do Riacho do Ipiranga";

"Este roteiro é seu! Escreva o seu nome:"; 


\section{Contracapa [2]}

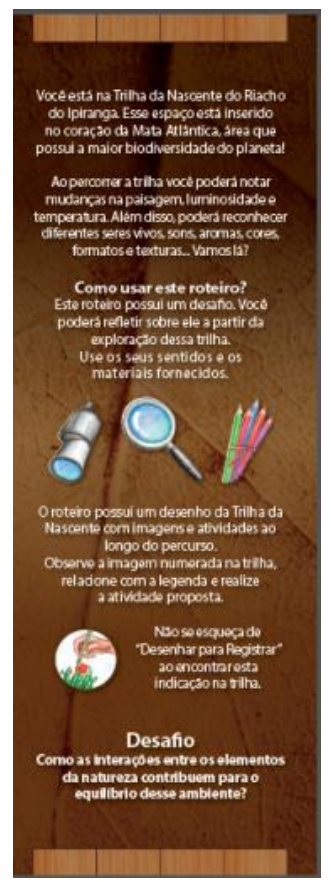

Esta aba é destinada para:

- Apresentação da Trilha, situando o contexto e destacando alguns diferenciais dessa exposição. Além disso há um parágrafo que tenta envolver o público nesse espaço estimulando à contemplação dos objetos expostos por meio da percepção e uso dos sentidos;

- Descrição do material e dicas de como utilizá-lo;

- Desafio: o desafio é proposto com a intencionalidade de "enlaçar" as atividades sugeridas no interior do roteiro em um tema comum. Sua criação está calcada na ideia de que refletir sobre situaçõesproblema, além de ser um elemento motivador. Busca assim auxiliar no desenvolvimento de habilidades, na construção de argumentos para responder à pergunta em questão e na compreensão das interações entre organismos e o ambiente, expressando, assim, a perspectiva dialógica do material.

Texto impresso:

"Você está na Trilha da Nascente do Riacho do Ipiranga. Esse espaço está inserido no coração da mata Atlântica, área que possui a maior biodiversidade do planeta!"

"Ao percorrer a trilha você poderá notar mudanças na paisagem, luminosidade e temperatura. Além disso, poderá reconhecer diferentes seres vivos, sons, aromas, cores, formatos e texturas... Vamos lá?"

"Como usar esse roteiro?"

"Este roteiro possui um desafio. Você poderá refletir sobre ele a partir da exploração dessa trilha. Use os seus sentidos e os materiais fornecidos."

"O roteiro possui um desenho da Trilha da Nascente com imagens e atividades ao longo do percurso. Observe a imagem numerada na trilha, relacione com a legenda e realize a atividade proposta."

"Não se esqueça de "Desenhar para Registrar" ao encontrar essa indicação na Trilha."

"Desafio"

"Como as interações entre os elementos da natureza contribuem para o equilíbrio desse ambiente?" 


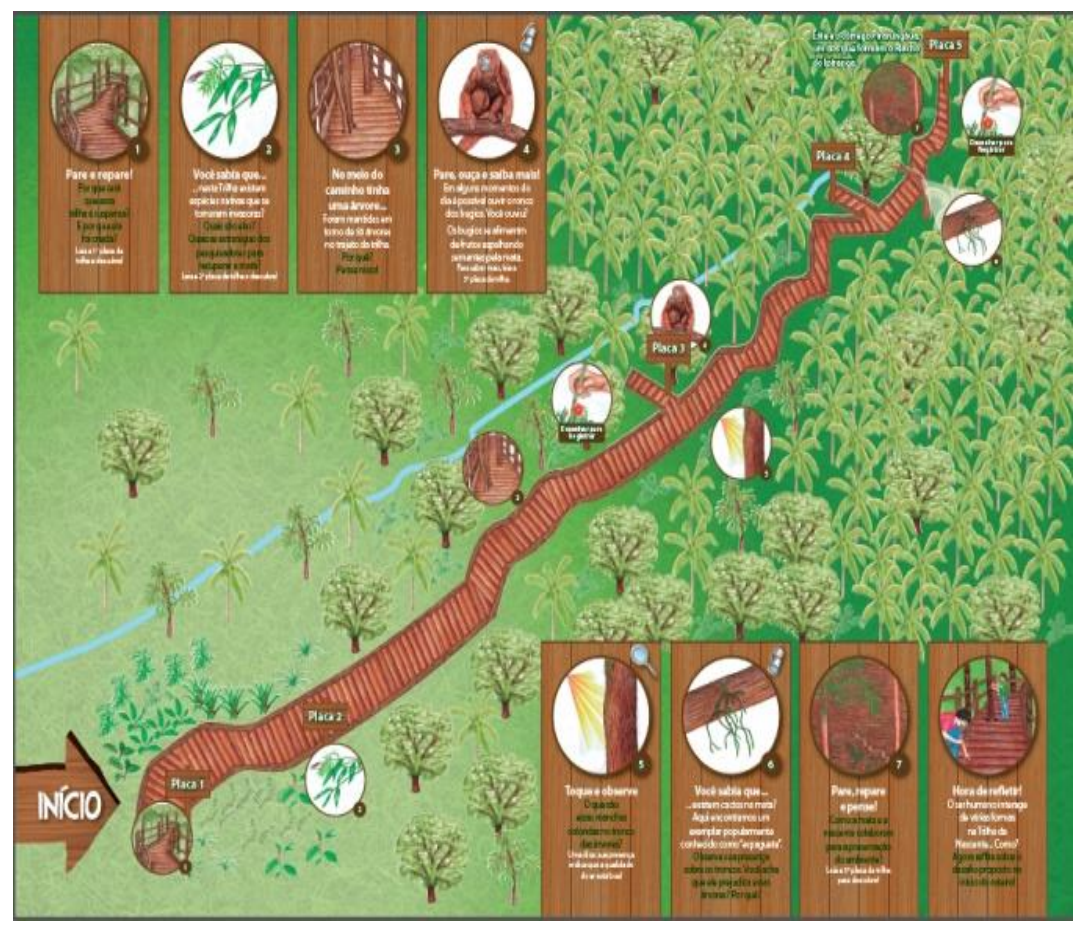

Interior do roteiro [5, 6, 7 e 8]

A área interna do roteiro é destinada a apresentar a Trilha da Nascente por meio de atividades que os visitantes deverão realizar e que são pautadas no estímulo a habilidades investigativas (Ash, 1999) e nos

indicadores de Alfabetização Científica (Cerati, 2014) que serão apresentadas no próximo tópico desse trabalho.

O croqui da Trilha e os objetos em destaque respeitam a ordem de leitura no padrão ocidental da esquerda para direita. As atividades propostas são subdividas em oito quadros, respeitando as dobras do roteiro. São utilizadas ilustrações científicas para representar o local, a própria Trilha e os objetos destacados pelo fato desse tipo de imagem ter o potencial de unir duas áreas do conhecimento: arte e ciência como indicam Suguituru e Morini (2012). Além de serem um dos discursos para a Comunicação da Ciência (CORREIA, 2013), as ilustrações científicas possuem a finalidade de "auxiliar o pesquisador a comunicar suas ideias e descobertas em forma de desenhos detalhados" (NICBIO). Assim, acreditamos que as ilustrações apresentadas nesse trabalho podem assumir e suscitar diferentes Indicadores de Alfabetização Científica às famílias que desejarem realizar a visita munidas desse roteiro.

O fundo do material tem coloração degrade, conforme a mata vai se tornando mais densa, e, embora não seja nosso objetivo - e nem possível - trazer a diversidade (variedade), a riqueza (número total) e a equidade (padrão de distribuição de indivíduos) de espécies vegetais neste local, essa imagem traz ilustrações de plantas e árvores que podem ser facilmente observadas na Trilha da Nascente. 


\section{Aba direita da janela fechada (orelha direita) [3]}

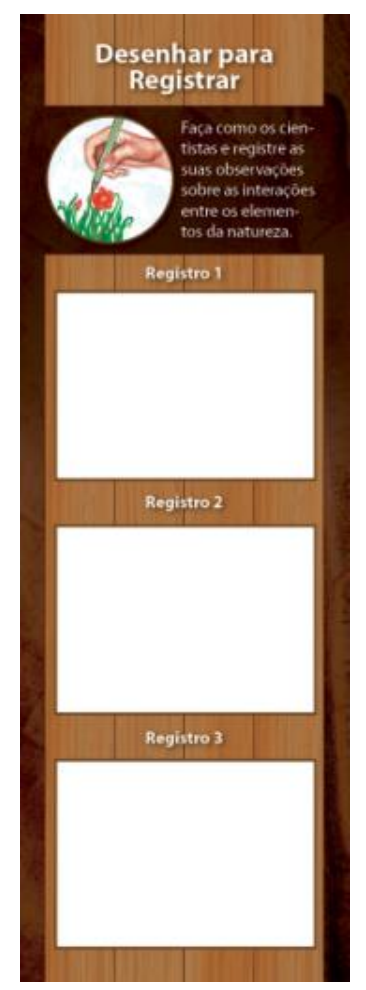

Para além da vasta literatura sobre o papel que as imagens e a escrita desempenham na construção do conhecimento na Didática das Ciências, registros desenhados têm surgido como subsídio para verificar o processo de construção da Alfabetização Científica em espaços de Educação Formal (SASSERON; CARVALHO, 2010).

De maneira convergente, esse trabalho dedicou três espaços para a realização de registros. O campo para tal aparece em branco e o desenho é estimulado pelo título "Desenhar para Registrar" e pelo fornecimento de um conjunto de lápis de cor para os visitantes. Além disso, há um ícone relacionado à ação de desenhar que está conectado as atividades propostas no roteiro.

Vale dizer que a ideia de incluir um espaço para desenho foi decorrente do reconhecimento das diversas dimensões - permeadas por questões de ordem cognitiva, linguística, afetiva e sociocultural - que o processo de AC envolve. Acreditamos que a realização de desenhos seja um dos meios possíveis de expressão para a representação de construções pessoais e, além de contribuir no processo de construção das ciências e do desenvolvimento de habilidades investigativas aos visitantes, o desenho pode ser explorado de maneira avaliativa pelo setor educativo dos espaços de educação não formal.

Texto impresso:

"Desenhar para Registrar"

"Faça como os cientistas e registre as suas observações sobre as interações entre os elementos da natureza."

"Registro 1"; "Registro 2"; "Registro 3". 


\section{VERSO [4]}

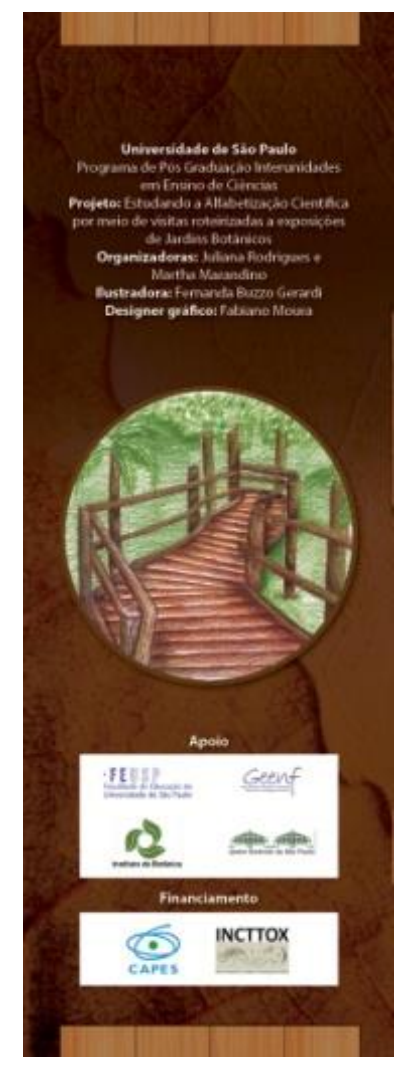

O verso deste roteiro apresenta, de forma concisa, informações pertinentes ao projeto de pesquisa ao qual o roteiro está inserido e dados sobre as fontes de apoio e financiamento do mesmo, além da autoria.

\section{Texto impresso:}

"Universidade de São Paulo"

"Programa de Pós-Graduação Interunidades em Ensino de Ciências"

"Projeto: Estudando a Alfabetização Científica por meio de visitas roteirizadas a exposições de Jardins Botânicos”

“Organizadoras: Juliana Rodrigues e Martha Marandino"

"Ilustradora: Fernanda Buzzo Gerardi"

"Designer gráfico: Fabiano Moura"

“Apoio (logos): GEENF - Grupo de Estudo e Pesquisa em

Educação Não Formal e Divulgação em Ciência, Faculdade de Educação, Instituto de Botânica e Jardim Botânico de São Paulo.”

"Financiamento: CAPES e INCTTOX"

As ilustrações a seguir apresentam a versão piloto do roteiro: 
Figura 8: Versão piloto do roteiro [externo e abas]

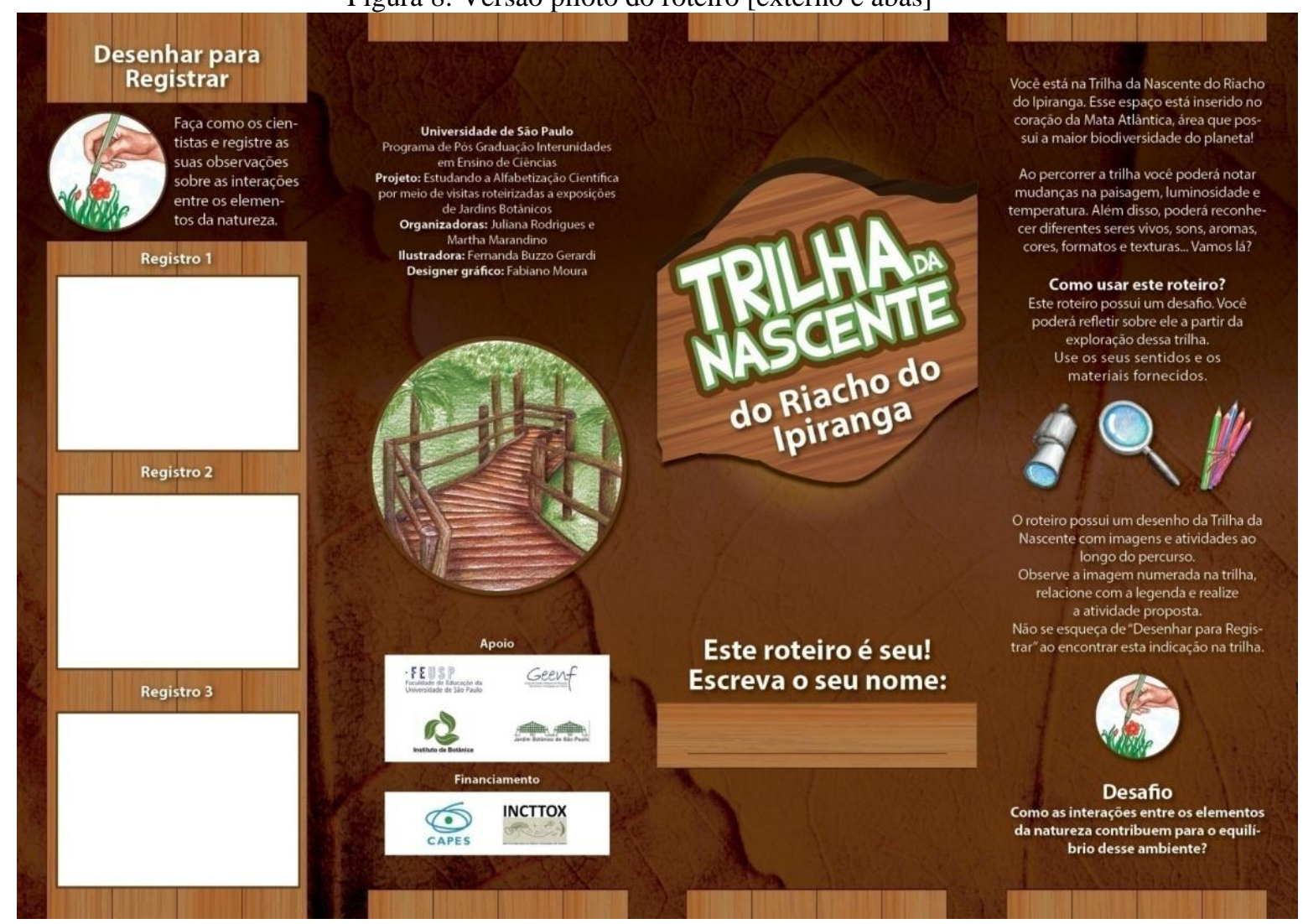

Fonte: elaboração própria 
Figura 9: Versão piloto do roteiro [interior]

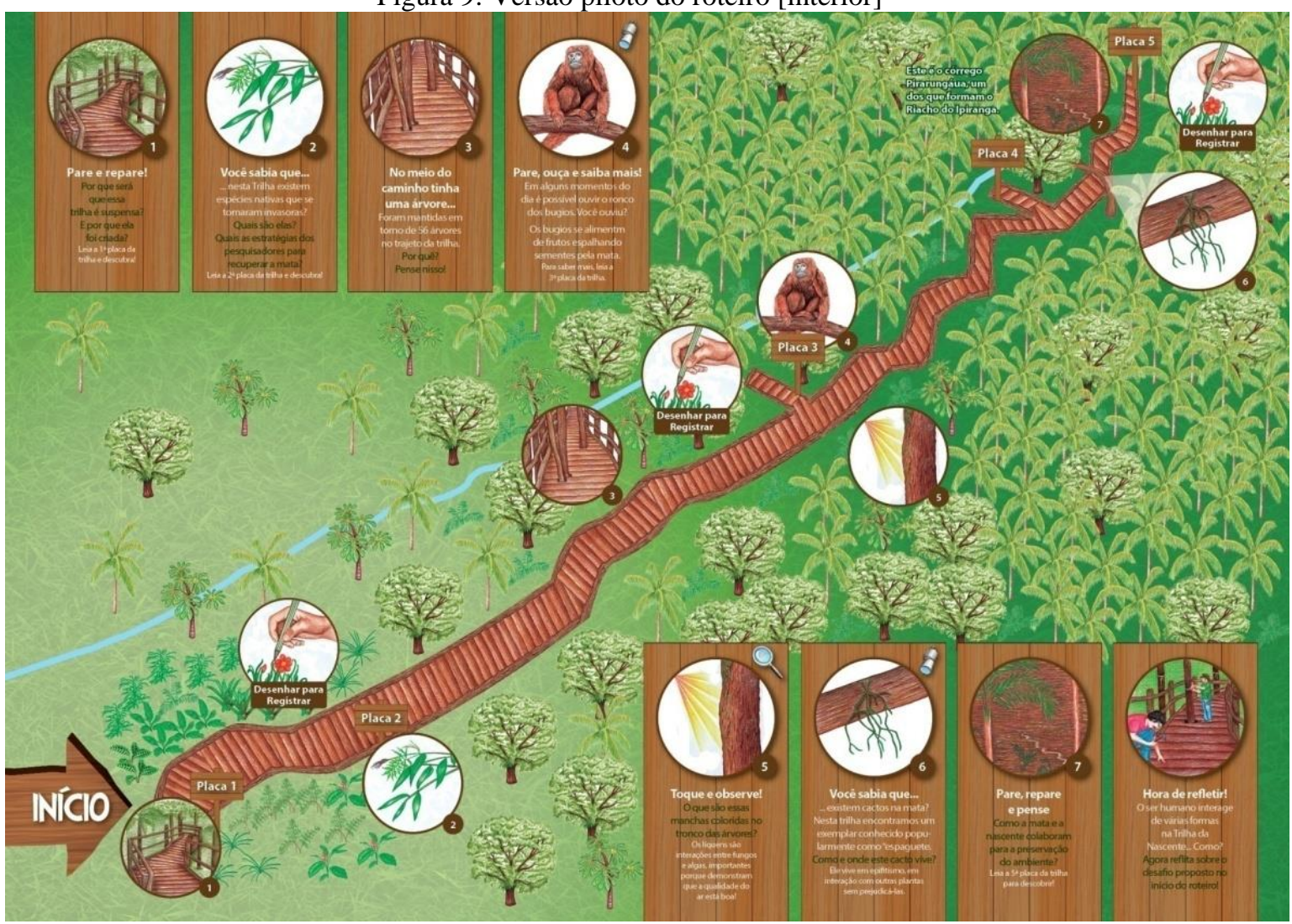

Fonte: elaboração própria

\section{b. Sobre as atividades do roteiro piloto para a promoção de $\mathrm{AC}$ em visitas à Trilha da Nascente}

As atividades, dispostas em quadros, são apresentadas no interior roteiro segundo os Indicadores e Atributos de Alfabetização Científica (Cerati, 2014) e as Habilidades investigativas (Ash, 1999) que este material deseja promover na interação com o público. Os quadros são formados pelos textos com diferentes níveis e por uma imagem, sendo que o texto principal fornece o comando da atividade a ser feita. De antemão adiantamos que para todas as ilustrações, buscamos estimular a percepção do atributo $\underline{\text { 4.c. Motivação }}$ $\underline{\text { do público no envolvimento com o tema exposto e facilitar o atributo } \underline{4 . b} \text {. Possibilidade }}$ de interação e contemplação dos elementos da exposição, pertencentes ao Indicador Estético/Afetivo (4). 


\section{3.b. Validação do roteiro}

Finalizada a versão piloto do roteiro, esta foi encaminhada para quatro grupos de indivíduos com a finalidade de avaliação e validação do material:

- Análise informal com um grupo de crianças - foi solicitado a 3 crianças com idade de 10 anos a análise quanto compreensão das informações fornecidas e linguagem da primeira versão ilustrada;

- $\quad$ Equipe do Jardim Botânico - a Equipe de estagiários e coordenação do Instituto de Botânica fez análise da versão intermediária entre a primeira versão e a versão piloto, fornecendo sugestões, sobretudo, no que tange à linguagem e à correção das informações de cunho técnico-científicas;

- Membros do GEENF - Grupo de Estudo de Pesquisa em Educação Não Formal e Divulgação da Ciência - foi solicitado a especialistas do campo da educação em museus que realizassem a análise da versão intermediária entre a primeira versão e a versão piloto no que diz respeito às informações, linguagem e layout do material voltado ao público almejado. Além disso, o grupo também poderia fornecer sugestões para sua melhoria e adequação ao público-alvo de famílias.

- $\quad$ Público (piloto) - três testes da versão piloto junto ao público foram feitos para a avaliação do material. Esses dados estão sendo analisados para nos auxiliar a perceber os ajustes necessários para a versão final. Mais informações sobre esse processo na próxima seção: "Aplicação da versão piloto do roteiro".

- Aplicação da versão piloto do roteiro - Após a finalização da versão piloto do roteiro, foi realizada a visita à Trilha da Nascente com três grupos de famílias, sendo a primeira composta por cinco pessoas, a segunda, por oito e a terceira por quatro, totalizando dezessete participantes, em dias diferentes.

As famílias foram abordadas próximas à entrada da trilha e convidadas a participar da pesquisa. Foi explicado a elas que se tratava de um teste cujo intuito era o de aprimorar um roteiro de visita desenvolvido para a Trilha da Nascente. Também foi dito que o projeto tinha intenção de estudar o potencial desse tipo de material para a promoção do processo de Alfabetização Científica junto a famílias em espaços de educação não formal. Nesse sentido, foram esclarecidas as dúvidas, os detalhes de participação e ressaltada a importância da realização do teste e participação da pesquisa. Após o aceite e realização da visita roteirizada, participaram de uma entrevista e assinaram autorização para o uso de imagens e sons para fins acadêmicos (Apêndice A). 
Para a realização da visita roteirizada, cada membro do grupo familiar recebeu o roteiro inserido na bolsa que continha os instrumentos de apoio para observação (monóculo e lupa) e registros (lápis de cor e base em acrílico para o apoio do roteiro) ao longo da trilha. Para coleta de dados junto a este público foram realizadas:

1) Observações dos sujeitos durante a vista buscando identificar a forma com que estes se apropriam do espaço. A interação entre si, com os objetos e textos da Trilha e com próprio roteiro e materiais fornecidos no kit ao longo da visita também foi objeto de atenção. Esta coleta foi registrada em um caderno de campo e por meio de gravação de vídeo.

2) Registro das conversas dos visitantes realizadas ao longo do percurso com a finalidade de identificar a presença ou não dos indicadores de AC nas falas mediadas pelo roteiro. Este momento foi registrado por meio de gravações de áudio e vídeo.

3) Entrevista semiestruturada com os participantes ao término das atividades buscando não só avaliar o roteiro e seu uso durante o percurso, como também as percepções sobre esse material (apresentação do layout/design, cores, formatos, tamanho e cores das fontes), uso dos materiais e informações disponibilizadas (uso do kit [monóculo, lupa, lápis de cor], informações adquiridas, realização do registro, compreensão do desafio) e o papel na promoção da AC. Vale dizer que o principal motivo para optarmos pelo tipo de entrevista semiestruturada se deu pelo fato do informante ter a possibilidade de discorrer sobre o tema proposto a partir de sua perspectiva e visão da experiência (GIL, 2008).

\section{3.c. Versão Final}

Para a produção da versão final do roteiro foi levado em conta todo o processo de elaboração das versões anteriores desse material. O "desafio" foi colocado no interior do roteiro com o intuito de dar maior destaque a este elemento; acrescentamos a figura feminina de uma pesquisadora negra para desconstruir um padrão hegemônico (homem e branco) de representação humana no desenvolvimento da ciência; o campo para registro foi modificado e tornou-se único para evitar controlar o ritmo de visita do público em paradas especificas para tal; os eixos temáticos ${ }^{7}$ foram mantidos, mas sem que os ícones

\footnotetext{
7 "Eixos temáticos" são aqui definidos como o conjunto de temas/assuntos que orientam o roteiro. Há, no conjunto de eixos temáticos, um encadeamento lógico dos conteúdos que estruturam a problematização proposta no material por meio do desafio, sem que a leitura na sequência desses temas seja obrigatória - já que cada indivíduo tem a liberdade de escolher a ordem dos assuntos que deseja explorar na trilha.
} 
estivessem elencados em pontos específicos da trilha. Em alguns poucos casos, alteramos a escrita de alguns eixos temáticos a fim de estimular, sobretudo, a maior incidência de alguns atributos dos indicadores institucional e interface social. Tais indicadores foram pouco vistos no trabalho de Cerati (2014), e a nossa experiência na aplicação da versão piloto do roteiro nos mostrou a possibilidade de fazer algumas aproximações entre este trabalho e o da referida autora, conforme explicitado no capítulo 4.2.b. "Discussão sobre os Resultados".

A seguir, apresentamos a versão final do roteiro. 
Figura 10: Versão final do roteiro [exterior e abas]

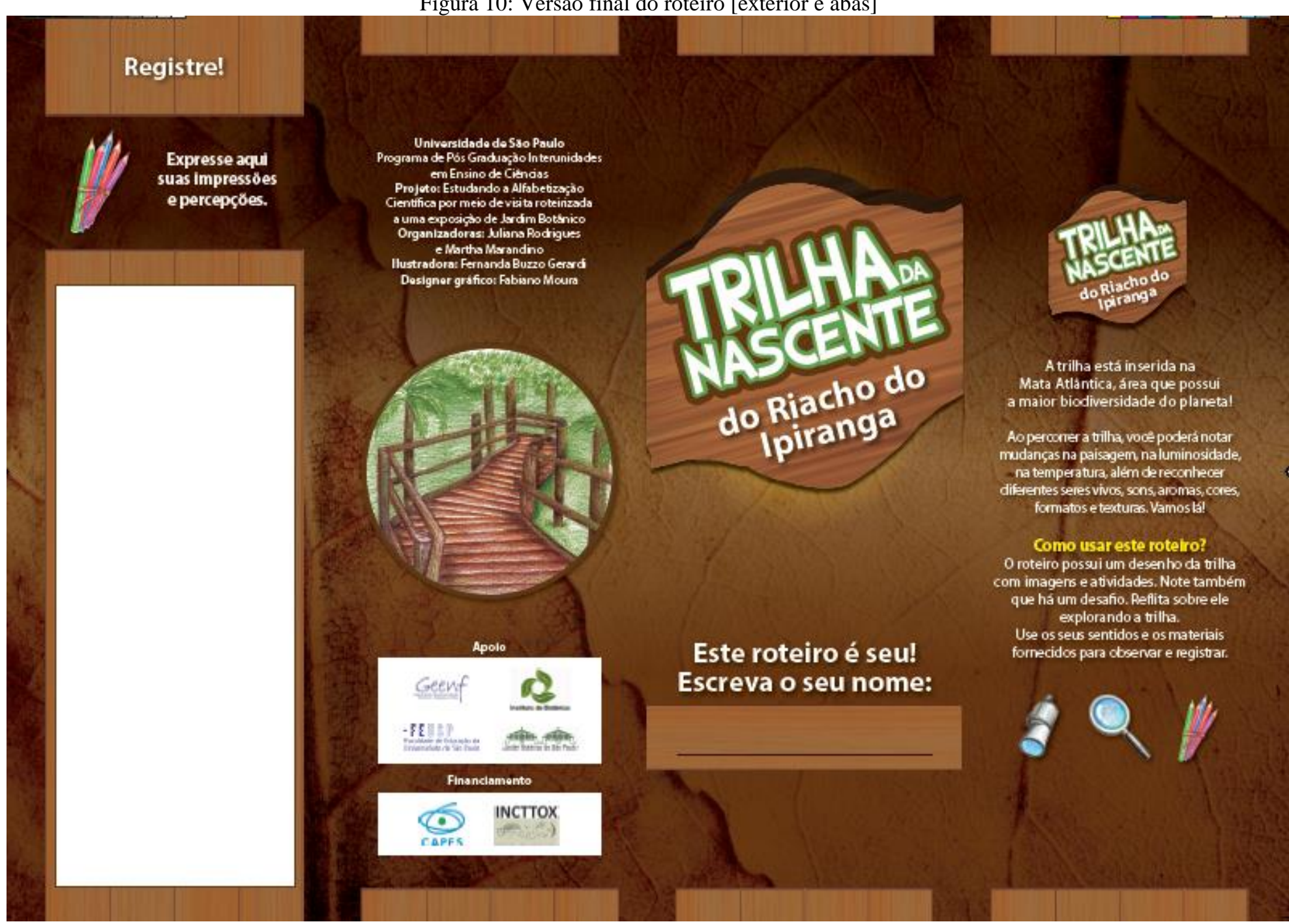

Fonte: Elaboração própria 
Figura 11: Versão final do roteiro [interior]

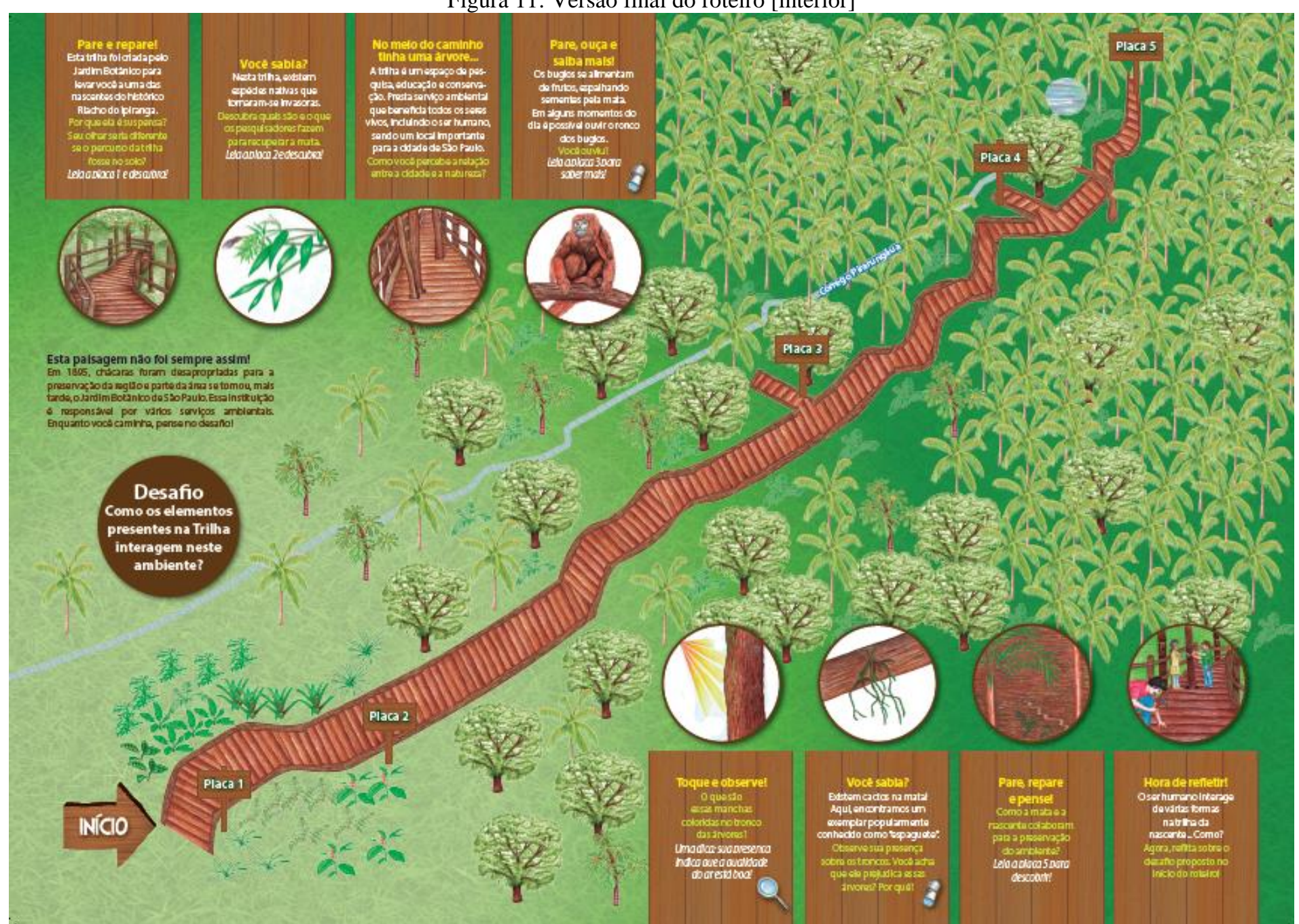

Fonte: elaboração própria 


\section{O POTENCIAL DO USO DO ROTEIRO NO PROCESSO DE AC EM VISITA A TRILHA DA NASCENTE: O QUE DIZEM OS DADOS?}

\subsection{Comentário inicial sobre a análise dos dados}

No plano de elaboração do roteiro de visita, e como objetivo desta pesquisa, as estratégias propostas ao longo do material visavam permitir aos visitantes perceber e experimentar alguns elementos da Trilha pautadas nos indicadores de Alfabetização Científica (CERATI, 2014) e no estímulo a habilidades investigativas (ASH, 1999). De acordo com a pesquisa de Cerati (2014), ao visitar a exposição Trilha da Nascente, as famílias tiveram uma experiência em um espaço de educação não formal que aborda assuntos científicos de maneira contextualizada e isso favoreceu alguns aspectos da Alfabetização Científica, mas também deixou outros de fora. Assim ao elaborar o roteiro, tínhamos a intenção de favorecer, além dos aspectos de AC identificados por esta pesquisadora, outras dimensões da AC que não foram contemplados ou foram pouco percebidas pelo público durante a sua investigação. Dentre essas dimensões, foi intenção que o roteiro promovesse uma percepção do Jardim Botânico enquanto um local de reflexão sobre a ciência, que envolve a produção e a divulgação de conhecimento, a dimensão humana da produção da ciência, a possibilidade de investigação e contemplação, entre outros aspectos. Mas o que efetivamente ocorreu com os grupos familiares ao visitarem a Trilha com apoio do roteiro?

Neste momento iremos apresentar a análise dos dados obtidos com uma das famílias estudadas durante a visita a Trilha da Nascente utilizando o roteiro produzido. Para esse fim, mobilizaremos a ferramenta teórico-metodológica de análise produzida por Cerati (2014) para a compreensão do processo de Alfabetização Científica em Jardins Botânicos. A seção foi organizada a partir dos eixos temáticos que foram usados na produção do roteiro impresso. Lembramos no roteiro existem quadros, com textos e imagens, produzidos a partir dos indicadores e atributos de Alfabetização Científica (Cerati, 2014) e das habilidades investigativas (Ash, 1999), previamente selecionadas por nós. Dentre os eixos temáticos, incluímos também a parte final do roteiro intitulada "Registre!" onde há um espaço em branco no qual o visitante é convidado a expressar suas impressões e percepções utilizando de lápis de cor que foi entregue junto ao roteiro.

Para apresentação dos dados, dividimos a análise a partir dos eixos temáticos do roteiro e, em cada um deles, os três itens abaixo foram descritos: 
Informações gerais: neste item retomamos o que foi proposto no roteiro e apresentamos cada quadro existente no material, formado pelos textos que contemplam diferentes níveis de interação com o público (ver processo de produção do roteiro no capítulo 3) e por uma imagem, sendo que o texto principal fornece o comando da atividade a ser feita. Optamos por esta apresentação como forma de retomar aqui a intenção do roteiro em cada um de seus elementos, facilitando o confronto com o que foi percebido pelos visitantes;

* Indicadores e atributos de AC e habilidades investigativas usadas na produção do roteiro: retomamos também nesta apresentação os indicadores e atributos de AC e as habilidades investigativas tomadas como referência para a produção do roteiro. Nesse sentido, os indicadores são potencialmente passíveis de percepção pelos visitantes na visita roteirizada.

Indicadores, atributos de AC e habilidades expressos pelos visitantes: para cada eixo temático procedemos a análise do que foi observado em campo durante a visita da família utilizando o roteiro e depois na entrevista. Indicamos, deste modo, quais foram os indicadores e atributos de $\mathrm{AC}$ e as habilidades investigativas percebidas nas falas dos sujeitos durante a visita e quais ficaram ausentes. Para facilitar a apresentação desses dados elaboramos uma síntese ao final de cada eixo, que revela os indicadores e atributos de AC e as habilidades investigativas: I) previstas pelo roteiro no respectivo quadro/eixo; II) identificadas durante a visita; e III) identificadas na entrevista pós-visita. 
4.2.A Alfabetização Científica na experiência do visitante usando o roteiro

\section{2.a. A análise por eixo temático}

I) Eixo temático: Trilha suspensa (quadro 1)

Figura 12: Recorte quadro 1 do Roteiro

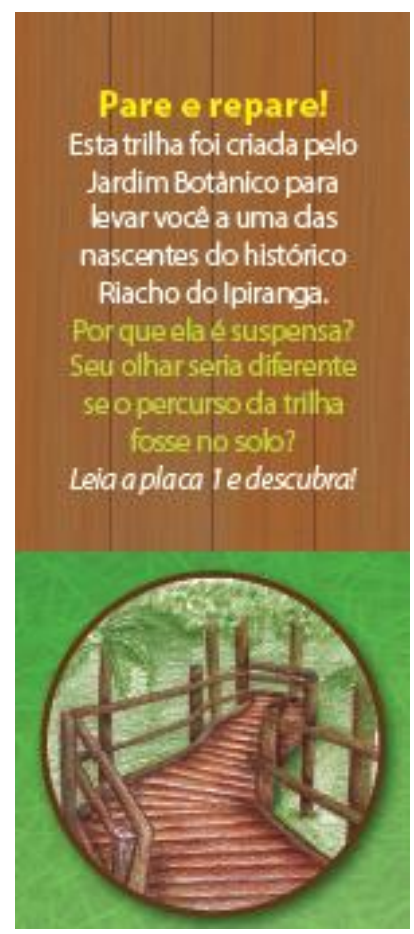

Fonte: elaboração própria

\section{I.1) Informações Gerais}

* Imagem: desenho com a vista da trilha suspensa após entrada na exposição Trilha da Nascente. Indica que se trata de uma trilha suspensa que adentra a Mata e é construída em madeira.

- Subtítulo: Pare e repare!

* Texto complementar ao subtítulo: Esta trilha foi criada pelo Jardim Botânico para levar você a uma das nascentes do histórico Riacho do Ipiranga.

* Texto Principal: Por que ela é suspensa? Seu olhar seria diferente se o percurso da trilha fosse no solo?

* Texto secundário: Leia a placa 1 e descubra! 
Figura 13: Imagem da placa 1 - Trilha do nascente

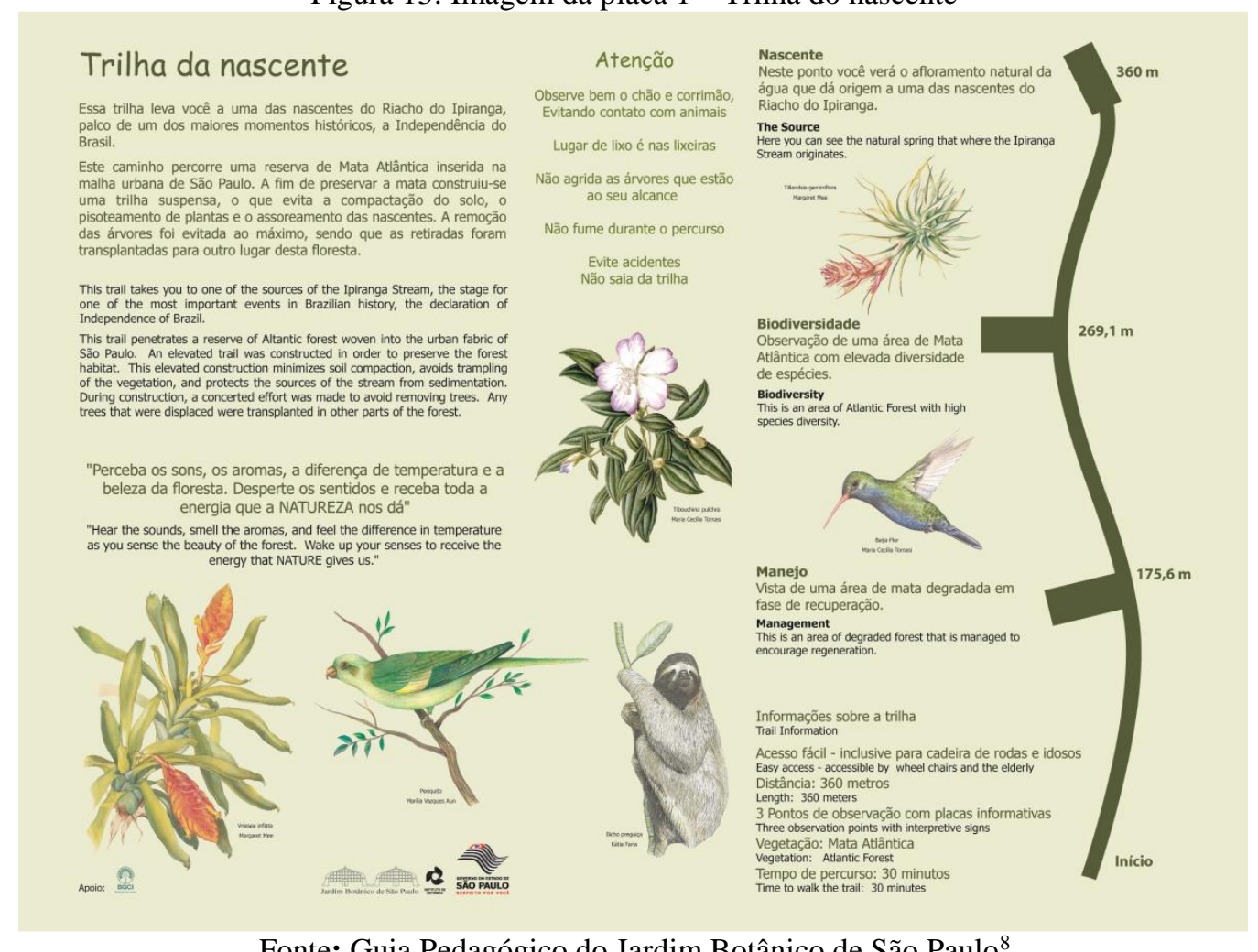

Fonte: Guia Pedagógico do Jardim Botânico de São Paulo ${ }^{8}$

Textos da placa 1 - Trilha da Nascente - Essa trilha leva você a uma das nascentes do Riacho do Ipiranga, palco de um dos maiores momentos históricos, a Independência do Brasil. Este caminho percorre uma reserva de Mata Atlântica inserido na malha urbana de São Paulo. A fim de preservar a mata construiu-se uma trilha suspensa, o que evita a compactação do solo, o pisoteamento de plantas e o assoreamento das nascentes. A remoção das árvores foi evitada ao máximo, sendo que as retiradas foram transplantadas para outro local da floresta. Perceba os sons, os aromas, a diferença de temperatura e a beleza da floresta. Desperte os sentidos e receba toda a energia que a floresta nos dá. Atenção - Observe o corrimão, evitando contato com os animais / Lugar de lixo é nas lixeiras / Não agrida as árvores que estão ao seu alcance / Não fume durante o percurso / Evite acidentes, não saia da trilha.

\section{I.2) Indicadores e atributos de AC e habilidades investigativas usadas na produção do roteiro:}

A ilustração, o subtítulo, assim como os questionamentos trazidos no texto principal e a dica ou comando para leitura das placas estimulam o indicador científico

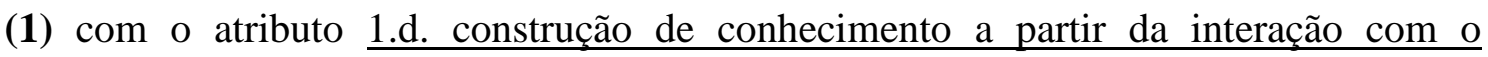
objeto/texto presente no discurso expositivo, já que o visitante pode relacionar o que está vendo no roteiro e nos objetos da trilha com o discurso presente na placa 01.

\footnotetext{
${ }^{8}$ Disponível em: http://www.ambiente.sp.gov.br/jardimbotanico/files/2013/08/guia-pedag\%C3\%B3gicodo-jardim-bot\%C3\%A2nico.pdf.
} 
Os textos do roteiro e da placa trazem ao leitor a dimensão histórica de uma das nascentes que formam o Riacho do Ipiranga, remetendo-se tanto ao ato simbólico de proclamação da independência do Brasil por D. Pedro I, quanto à relevância deste símbolo geográfico da história de São Paulo do país preservada pelo Jardim Botânico. Ao envolver o público nessa dimensão histórica e ao instigar a reflexão sobre o fato da trilha ser suspensa, foi intenção dar destaque ao indicador institucional (2) nos atributos 2.a. importância das coleções mantidas pela instituição, 2.b. missão institucional como produtora e disseminadora de conhecimento científico, pois ao ler a primeira placa da Trilha o visitante terá acesso a informações sobre a missão institucional relacionada à conservação e 2.e. contextualização da dimensão histórica da instituição e seu papel para o desenvolvimento científico.

Esse quadro incita o indicador estético/afetivo (4) com os atributos $\underline{4 . a}$. expressão de sentimentos, $\underline{4 . b}$. possibilidade de interação e contemplação dos elementos da exposição e 4.c. motivação do público no envolvimento com o tema exposto, pois visa instigar o visitante à observação e à percepção do ambiente ao seu redor, ação que pode desencadear questionamentos e impressões sobre os temas abordados na exposição, auxiliando na compreensão e no raciocínio do tema exposto.

Em termos de habilidades investigativas, procurou-se neste eixo temático estimular a observação da própria trilha, para uma reflexão e análise que levasse o visitante a propor explicações sobre a razão da construção da mesma, permitindo que ele pudesse emitir opinião e tirar conclusões.

\section{I.3) Indicadores, atributos e habilidades expressos pelos visitantes:}

Em nossa análise, buscamos relacionar os indicadores de Alfabetização Científica e os atributos esperados com o uso do roteiro àqueles que efetivamente apareceram na fala dos participantes durante e/ou após a visita, no momento da entrevista.

Lembramos que a família estudada é composta por três membros, sendo Laura, a mãe, Antônia, a filha, e Maria, a cunhada/tia. Ao longo da visita, o roteiro ficou maior parte do tempo na mão de Maria.

No início da visita, Maria e Laura dão uma rápida olhada no roteiro e, ao adentrar o espaço expositivo, param em frente à primeira placa da trilha. Maria chama a atenção da sobrinha para algumas ilustrações na placa 1 da fauna local. As imagens captadas no 
vídeo e a nossa observação revelam que Antônia e Laura não portavam o roteiro neste momento da leitura da placa.

Em seguida, iniciam a caminhada na trilha com Maria lendo e segurando o roteiro aberto. No turno 09, Laura olhando para a mata, afirma:

Olha, Antônia, está tudo no alto. Você viu onde a gente está? Olha lá pra baixo, tem um monte de coisa pequenininha (Laura, turno 09)

Laura expressa a observação dos elementos vistos em perspectiva pelo fato da trilha ser suspensa e, ao convidar Antônia para fazer o mesmo, ela também destaca que o que está observando é "bem pequenininho...” (Antônia, turno 10). No turno 26, Laura retoma essa percepção com a fala: “Tá bem no alto, né?”.

Como indicado, no texto do quadro 1 do roteiro há duas perguntas relacionadas ao fato da trilha ser suspensa: "por que ela é suspensa?" e "seu olhar seria diferente se o percurso da trilha fosse no solo? ". Além disso, o roteiro orienta para que a placa 1 seja lida pelos visitantes e que esta pode ajudar nas respostas às perguntas feitas. Considerando estas orientações e o observado, podemos afirmar que, a partir do roteiro, a família percebe que a trilha é suspensa, além da forma específica de se relacionar com os elementos que nela existem. Mesmo que as características da trilha suspensa não tenham sido expressas literalmente na fala dos visitantes, há fortes indícios de que o roteiro apoiou a forma com que Laura e Antônia observaram a mata a partir da trilha suspensa.

Além disso, Maria lê a placa 01 da Trilha, conforme estimulado pelo roteiro e, ao apontar os elementos ilustrativos existentes nela, procura instigar a curiosidade da sobrinha em adentrar o espaço e observar alguns dos seres ali existentes. Importante mencionar que a placa 01 apresenta uma vista geral da exposição Trilha da Nascente com pontos de observação e placas informativas e, além de elencar alguns aspectos históricos e explicar porque é suspensa, traz orientações e informações sobre a trilha, bem como ilustrações científicas de espécimes de flora e fauna existentes na área.

Em momentos posteriores da visita é notória a expectativa de Maria em ver o bicho preguiça (um dos elementos faunísticos por ela destacado na placa 01) e, em suas falas (turnos 63, 92, 98, 163, 255, 342, 367, 408), retoma esse componente como forma de estimular a observação dos demais integrantes do grupo no ambiente.

A partir dos dados apontados, podemos afirmar que nos turnos 09 e 26, quando Laura ressalta a perspectiva do seu olhar para a suspensão da trilha e convida Antônia para fazê-lo, se faz presente a habilidade investigativa de observação. Por sua vez, quando 
Antônia, no turno 10, corrobora com a observação realizada pela mãe dizendo "bem pequenininho" a habilidade investigativa afirmação - que não havia sido prevista no momento de concepção do material - torna-se notória e, quando, no turno 11, Maria diz "legal explorar aqui, né?" a habilidade emissão de opinião aparece.

Durante a entrevista, notamos as habilidades explicação e emissão de opinião já que Laura comenta porque achou importante e interessante a trilha ser suspensa:

Eu gostei do caminho, assim, no alto, porque você não fica, às vezes atolando, se perdendo, você fica, segue o caminho certinho. (Laura)

Ah, eu já gostei no alto, porque eu acho que é uma experiência diferente, porque a gente fica, sempre vê a árvore ali só aquele pedacinho que a gente alcança, aí você vê mais pra cima é mais legal. Assim, uma visão diferente. (Laura)

No que se refere aos indicadores de AC, observou-se nesse eixo temático apenas o indicador estético afetivo, com o atributo 4.b.interação e contemplação dos elementos da exposição, expresso especialmente quando Laura e Antônia percebem que a visão de cima da trilha suspensa é em perspectiva e os elementos da mata ficam "pequenos". Outros atributos deste indicador são: $\underline{4 . a . ~ e x p r e s s a ̃ o ~ d e ~ s e n t i m e n t o s ~ e ~ o ~} \underline{4 . c}$ que se refere à motivação do público no envolvimento como tema exposto e que é expresso tanto durante a visita, quando Maria emite espontaneamente uma opinião "legal explorar aqui, né?" (turno 11) e na entrevista ao final da visita, quando Laura e Maria discorrem sobre a vivência de percorrer uma trilha suspensa, conforme exposto abaixo:

Você acha melhor estar no alto? Eu acho melhor. (Laura)

Eu não vejo, assim, questão de ser melhor ou pior, eu vejo questão de diferença, mesmo, porque quando você está no alto, a sua tendência é ficar olhando para cima, mesmo, porque você já está no alto. Agora, quando você está andando no chão, que nem a gente brincou com ela agora há pouco, para tirar a meia dela, porque eu tirei o sapato, a mãe dela tirou o sapato. "ANTONIA, vamos tirar o sapato para sentir a terra", porque geralmente, em casa, a gente fica, "põe o chinelo, põe a meia, põe o sapato", por conta do piso frio. E aqui não precisa disso, então a gente falava, "tira o chinelo", e ela estava desesperada, porque acostumou, desde bebê, a pôr sapato, ficar brigando, "põe o chinelo, põe o sapato". Quando chegou aqui, que tinha que tirar, ela ficou em pânico, ela não soube lidar. Então, se a gente tivesse feito uma trilha caminhando, com certeza seria diferente, até eu acho que eu tiraria o sapato para sentir melhor a natureza, sentir melhor o chão. Tanto é que quando você anda descalço num lugar desse, não machuca o pé e é bom para descarregar as energias, tal, você se sente mais revigorado. E a gente queria que ela sentisse essa mesma experiência, mas ela estava apavorada com a situação. (Maria) 
Estava, ela foi resolvendo andar de meia, pisou com a meia no molhado, deu um grito. (Laura)

Eu vou ir lá de novo, para molhar. (Antônia)

Olha que interessante, geralmente criança gosta de se espojar, correr. "Vai, ANTONIA, corre, vai, aproveita, é seu momento". Grudou na gente, com medo, talvez até por conta de que ela nunca veio num lugar desse, foi a primeira vez, então ela ficou apavorada com a possibilidade de poder ficar livre. Então acho que se a trilha fosse, também seria divertido para gente, para ela. (Maria)

\section{É. (Laura)}

É, que nem, no alto, foi legal no alto, tal, mas no alto a gente fica meio preocupada, ah, não pode chegar muito perto, assim, para não cair, ela, tal, ela também tem medo de altura. Agora, assim, acho que não. (Maria)

Ah, eu já gostei no alto, porque eu acho que é uma experiência diferente, porque a gente fica, sempre vê a árvore ali só aquele pedacinho que a gente alcança, aí você vê mais pra cima é mais legal. Assim, uma visão diferente. (Laura)

Face ao exposto, destacamos que, dos três indicadores esperados para este eixo temático, apenas um deles foi contemplado nas falas durante a visita desta família, qual seja, o estético/afetivo. A nosso ver, a pergunta feita no texto do quadro 1 referente à experiência de observação do visitante a partir da trilha suspensa possui caráter empírico e isso favoreceu este indicador.

Por outro lado, os indicadores científico e institucional não foram identificados nas falas neste momento de uso do roteiro, e a frase neste primeiro eixo temático que tinha a intenção de promovê-los era "Esta trilha foi criada pelo Jardim Botânico para levar você a uma das nascentes do histórico Riacho do Ipiranga”. Havia uma expectativa de que a menção no roteiro de que a trilha havia sido criada pela instituição e que a nascente pertence ao Riacho do Ipiranga junto com a pergunta colocada no roteiro porque ela é suspensa? - levasse à leitura da primeira placa pelo visitante. Com as informações fornecidas pela placa 01 seria possível perceber que a Trilha da Nascente foi construída de forma suspensa a fim de preservar a mata e evitar a compactação do solo, o pisoteamento de plantas e o assoreamento das nascentes, conforme apontado no texto da placa. A expectativa era que, com o uso do roteiro, houvesse evidências nos diálogos do atributo $\underline{1 . d \text {. construção de conhecimento a partir da interação com o objeto/texto }}$ presente no discurso expositivo relativo ao indicador científico (referentes à preservação do solo e da nascente por exemplo). Além disso, com o uso do roteiro e leitura da placa, 
havia a expectativa de que, nos diálogos, houvesse alguma menção aos atributos 2.a. importância das coleções mantidas pela instituição e 2.b. missão institucional como produtora e disseminadora de conhecimento científico relativos ao Indicador Institucional, já que o texto informa que foi o Jardim Botânico que produziu a trilha para promover a possibilidade de observar um riacho histórico. Contudo, as falas da família não fizeram referências a esses temas ao longo da visita.

Quadro 4 - Síntese dos Indicadores de Alfabetização Científica, Atributos e Habilidades Investigativas relacionados ao quadro 01 do roteiro

\begin{tabular}{|c|c|c|c|}
\hline Indicadores-Atributos/Habilidades & $\begin{array}{l}\text { Antes/na } \\
\text { produção do } \\
\text { roteiro }\end{array}$ & $\begin{array}{c}\text { Durante a } \\
\text { visita }\end{array}$ & $\begin{array}{c}\text { Após a } \\
\text { visita/entrevista }\end{array}$ \\
\hline \multicolumn{4}{|l|}{ Científico (1): } \\
\hline $\begin{array}{l}\text { 1.d. Construção de conhecimento a partir da } \\
\text { interação com o objeto/texto presente no } \\
\text { discurso expositivo }\end{array}$ & $\mathrm{X}$ & - & - \\
\hline \multicolumn{4}{|l|}{ Institucional (2): } \\
\hline $\begin{array}{l}\text { 2.a. Importância das coleções mantidas pela } \\
\text { instituição }\end{array}$ & $\mathrm{X}$ & - & - \\
\hline $\begin{array}{l}\text { 2.b. Missão institucional como produtora e } \\
\text { disseminadora de conhecimento científico }\end{array}$ & $\mathrm{X}$ & - & - \\
\hline $\begin{array}{l}\text { 2.e. contextualização da dimensão histórica da } \\
\text { instituição e seu papel para o desenvolvimento } \\
\text { científico }\end{array}$ & $\mathrm{X}$ & - & - \\
\hline \multicolumn{4}{|l|}{ Estético/Afetivo (4): } \\
\hline 4.a. expressão de sentimentos & $\mathrm{X}$ & - & $\mathrm{X}$ \\
\hline $\begin{array}{l}\text { 4.b. Possibilidade de interação e contemplação } \\
\text { dos elementos da exposição }\end{array}$ & $\mathrm{X}$ & $\mathrm{X}$ & - \\
\hline $\begin{array}{l}\text { 4.c. Motivação do público no envolvimento com } \\
\text { o tema exposto }\end{array}$ & $\mathrm{X}$ & $\mathrm{X}$ & $\mathrm{X}$ \\
\hline \multicolumn{4}{|l|}{ Habilidades investigativas: } \\
\hline Observação & $\mathrm{X}$ & $\mathrm{X}$ & - \\
\hline Afirmação & - & $\mathrm{X}$ & - \\
\hline Explicação & $\mathrm{X}$ & - & $\mathrm{X}$ \\
\hline Emissão de opinião & $\mathrm{X}$ & $\mathrm{X}$ & $\mathrm{X}$ \\
\hline Conclusão & $\mathrm{X}$ & - & - \\
\hline
\end{tabular}


II) Eixo temático: Espécies invasoras nativas 9 e manejo (quadro 2)

Figura 14: Recorte quadro 2 do Roteiro

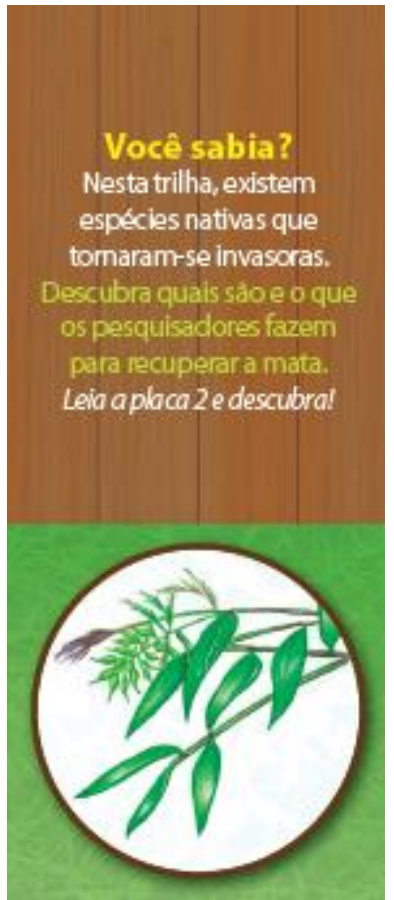

Fonte: elaboração própria

\section{II.1) Informações Gerais}

Imagem: o desenho representa o bambu existente na Trilha e que corresponde a uma das duas espécies descritas na segunda placa [Chusqueacapituliflora var. pubescensMcClure \&L.B.Sm $e$ Parodiolyramicrantha (Kunth) Davidse\&Zuloaga].

- Subtítulo: Você sabia?

* Texto complementar ao subtítulo: Nesta Trilha, existem espécies nativas que tornaram-se invasoras.

* Texto Principal: Descubra quais são e o que os pesquisadores fazem para recuperar a mata.

Texto secundário: Leia a placa $2 e$ descubra!

\footnotetext{
${ }^{9} \mathrm{O}$ roteiro traz a ilustração de uma das espécies de bambu que também pode ser vista na segunda placa da
} trilha [Chusquea capituliflora var. pubescens e Parodiolyra micrantha]. 
Figura 15: Imagem da Placa 2 - Manejo

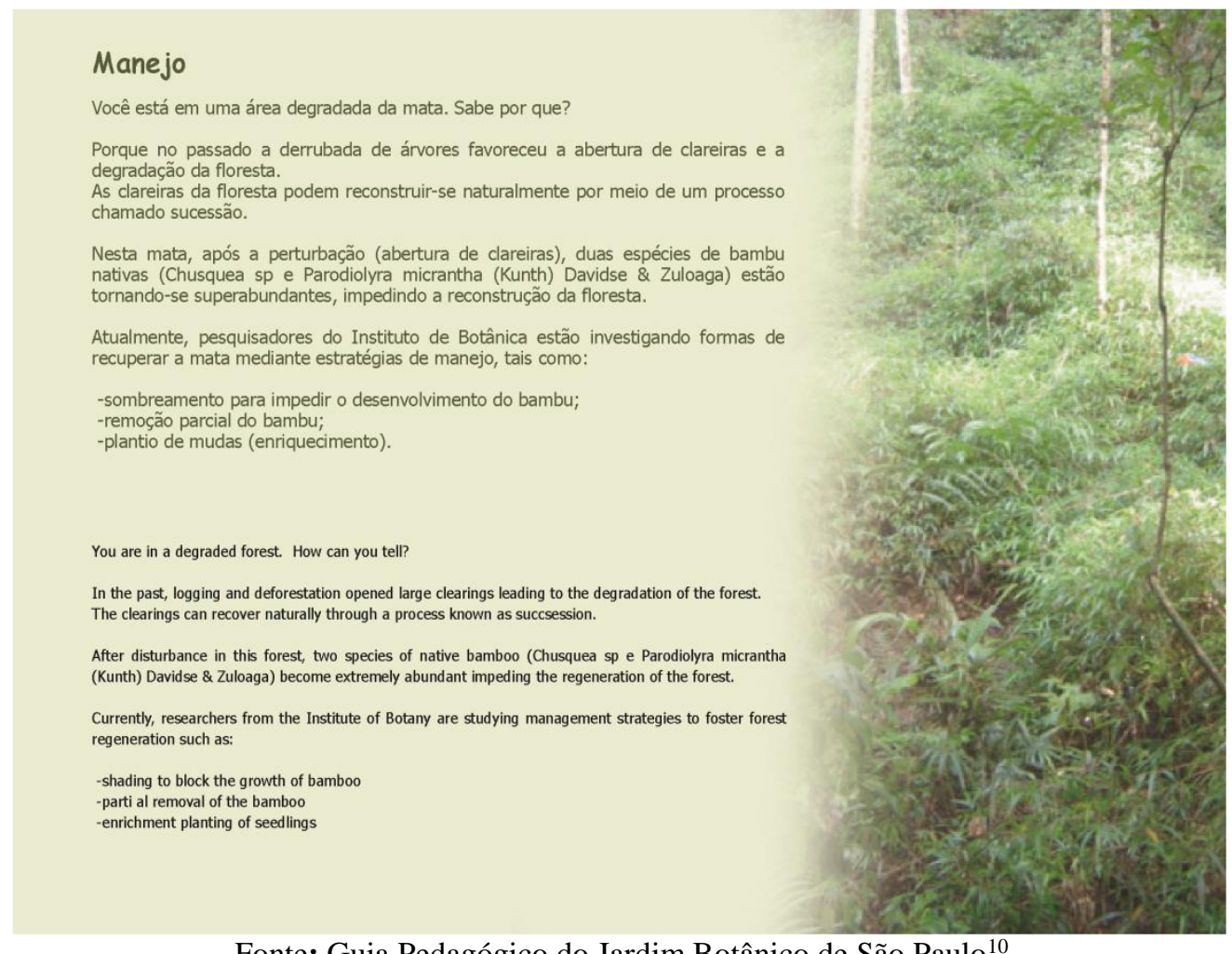

Fonte: Guia Pedagógico do Jardim Botânico de São Paulo ${ }^{10}$

Texto da Placa 2 - Manejo - Você está em uma área degradada. Sabe por quê? Porque no passado a derrubada de árvores favoreceu a abertura de clareiras e a degradação da floresta. As clareiras da floresta podem reconstruir-se naturalmente por meio de um processo chamado sucessão. Nesta mata, após a perturbação (abertura de clareiras), duas espécies de bambu nativas (Chusqueasp $e$ Parodiolyramicracantha(Kunth) Davidse\&Zuloaga) estão tornando-se superabundantes, impedindo a reconstrução da floresta. Atualmente pesquisadores do Instituto de Botânica estão investigando formas de recuperar a mata mediante estratégias de manejo, tais como: Sombreamento para impedir o desenvolvimento do bambu; Remoção parcial do bambu; Plantio de mudas (enriquecimento).

\section{II.2) Indicadores e atributos de AC e habilidades investigativas usadas na produção} do roteiro:

A ilustração, o subtítulo e o texto complementar, assim como os questionamentos trazidos no texto principal e o texto secundário (comando para leitura das placas) remetem aos seguintes indicadores: o subtítulo e o texto complementar ao subtítulo, embora se apresentem na forma de pergunta, têm caráter informativo e, portanto, trazem o indicador científico (1).

E, já que o visitante pode relacionar o roteiro e os objetos da Trilha com o discurso presente na Placa da própria trilha, o atributo $\underline{1 . a \text { conceitos científicos e suas definições é }}$

\footnotetext{
${ }^{10}$ Disponível em: http://www.ambiente.sp.gov.br/jardimbotanico/files/2013/08/guia-pedag\%C3\%B3gicodo-jardim-bot\%C3\%A2nico.pdf.
} 
também estimulado. Isso porque, ao fazer com que o visitante busque a denominação da espécie ao qual o quadro se refere na placa, estimula-se o contato com o conceito de sucessão ecológica ali exposto. Além disso, a partir dessa interação, existe a possibilidade de que se construa novos conhecimentos remetendo ao atributo $\underline{1 . d \text {. construção de }}$ conhecimento a partir da interação com o objeto/texto presente no discurso expositivo. Ao questionar as estratégias dos pesquisadores para recuperação da mata, o quadro 2 do roteiro tem a intenção de provocar o indicador institucional (2) no atributo 2.b. missão institucional como produtora e disseminadora de conhecimento científico e as discussões podem retomar o indicador científico no que tange aos atributos $\underline{1 . b \text { resultados da }}$ pesquisa científica e 1.e. papel do pesquisador no processo de produção do conhecimento.

Com relação ao indicador estético/afetivo (4), os atributos considerados na produção do roteiro foram: $\underline{4 \text { b. possibilidade de interação e contemplação dos elementos }}$ da exposição e 4.c. motivação do público no envolvimento com o tema exposto, pois visam instigar o visitante à observação de espécies nativas e à percepção do ambiente ao seu redor, ação que pode desencadear questionamentos e contribuir para a compreensão do tema exposto

Para realizar a atividade esperou-se que ocorresse as habilidades investigativas de observação e o reconhecimento das espécies de bambu supracitadas. E, também que, por meio da leitura da placa, os visitantes pudessem expressar a habilidade de explicar a ideia de sucessão ecológica para que fossem identificadas e compreendidas a necessidade das estratégias de manejo que os pesquisadores do Instituto de Botânica têm estudado.

\section{II.3) Indicadores, atributos e habilidades expressos pelos visitantes:}

Enquanto caminham em direção à nascente, Laura para em frente à segunda placa da trilha com o título "Manejo", e lê, em voz alta, parte do texto da placa: "abertura de clareiras" (turno 14) e, num primeiro momento, não externaliza relações entre o que leu na placa e as informações contidas no roteiro. No entanto, ao retornar pela trilha (lembrando que o percurso de ida é o mesmo que de volta), a família parou defronte à segunda placa 2 novamente e, enquanto Maria e Antônia observam o tronco da árvore ao lado com a lupa, Laura lê a placa atentamente. 


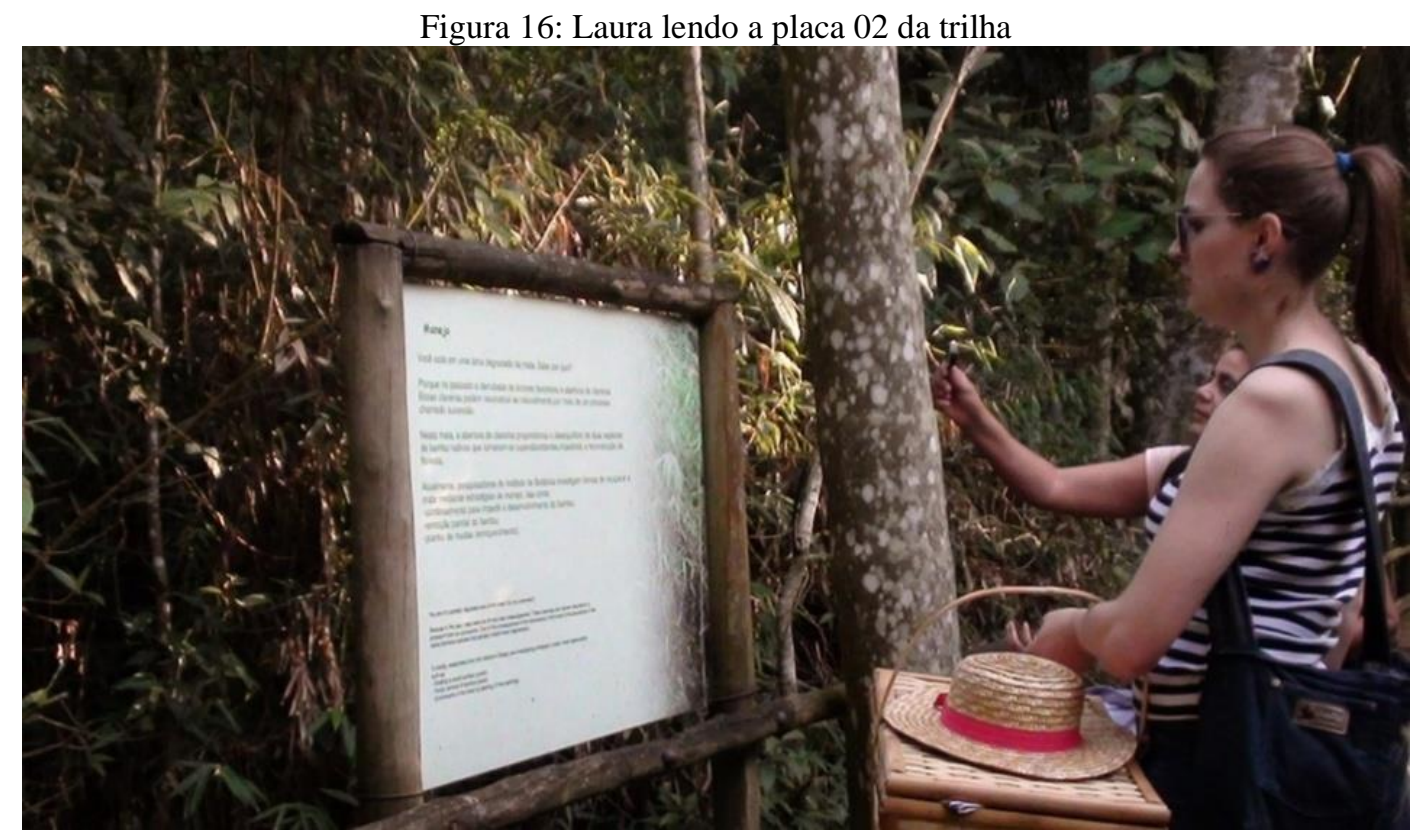

Fonte: elaboração própria

Ao ver Laura com os olhos fixados no texto, Maria também o faz. Antônia observa para a placa aparentemente buscando entender o que a mãe e a tia observam e Laura então aponta para a imagem do bambu na placa e diz "Fez um desequilíbrio; ficou superabundante" (turno 619). Nesse momento, Maria complementa: "Interessante, né? Não pode ser nem de mais, nem de menos" (turno 620) e, no turno seguinte - 621 - Laura se reporta às estratégias de manejo pensadas pelos pesquisadores do Jardim Botânico de São Paulo como forma de controlar e recompor a área degradada: "É, agora eles tão vendo de fazer o sombreamento para ele não desenvolver ou remover o bambu".

Essa ideia é retomada na entrevista quando Maria e Laura relembram as informações lidas na placa para responder a um questionamento sobre equilíbrio ecológico:

A gente estava olhando uma placa, que estava explicando que está cheio de bambu aqui e um pessoal que cuida do parque estava vendo como é que ia manter o controle, porque se uma espécie sobressair à outra, acaba prejudicando as outras, também. Então até mesmo dentro da natureza tem que ter um equilíbrio, não pode ter uma espécie de mais nem de menos. Porque prejudica, também, a alimentação dos outros bichos e tal, então eu achei interessante, que ela falou que eles estavam... o que que eles estavam fazendo? (Maria)

Eles estão estudando para ver como que eles vão fazer, se eles vão, três formas: eles vão tirar os bambus que estão em excesso ou eles vão tirar a iluminação, deixar mais escuro, que eles não procriam muito, e plantar mudas de outras plantas pra ter o equilíbrio melhor (Laura) 
A partir dos dados percebe-se que, nas paradas para leitura da placa, a habilidade investigativa observação é notória. Além disso, quando Laura se propõe a sintetizar o que está lendo à Antônia (turnos 619 e 621) identificamos a habilidade de explicação. $\mathrm{O}$ comentário de Maria durante visita “interessante, né? Não pode ser nem de mais, nem de menos" (turno 620) revela duas outras habilidades investigativas que surgiram na visita e/ou na entrevista, mas que não estavam previstas no roteiro: afirmação - já que corrobora com a observação de Laura expressa no turno anterior - e emissão de opinião, pois carrega consigo a manifestação de uma ideia e emissão de um juízo acerca do fenômeno ali exposto. Essa última habilidade é retomada na entrevista com a fala de Maria: “[...] porque se uma espécie sobressair à outra, acaba prejudicando as outras, também. Então até mesmo dentro da natureza tem que ter um equilíbrio, não pode ter uma espécie de mais nem de menos".

Percebe-se também a habilidade de explicação na entrevista, quando Laura complementa a fala de Maria e justifica a relação por ela estabelecida entre a problemática de superabundância à questão do equilíbrio ecológico.

Sobre os indicadores e atributos de $\mathrm{AC}$, as falas das visitantes referem-se às estratégias de manejo investigadas pelos pesquisadores do Instituto de Botânica estão para a recuperação a mata e, por terem sido divulgadas na exposição, reforçam o

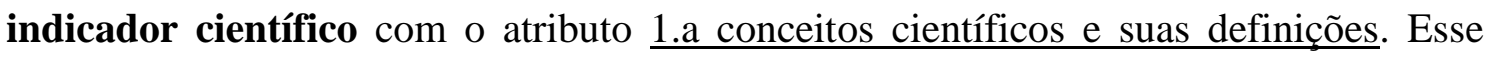
atributo manifesta-se quando Laura parece demonstrar ter assimilado o conceito de sucessão ao dizer na entrevista sobre a necessidade de "plantar mudas de outras plantas pra ter o equilíbrio melhor”, já que esta estratégia de recuperação de áreas degradadas se caracteriza por ser um processo de instalação gradual de organismos. Além disso, o

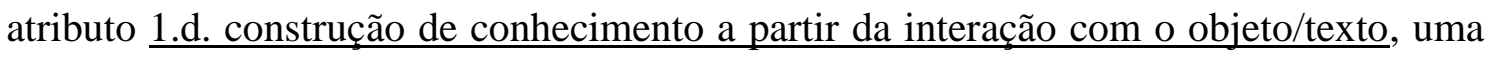
vez que as visitantes se apropriaram e incorporaram nas suas falas informações presentes no discurso expositivo para compor um argumento de como diversos elementos

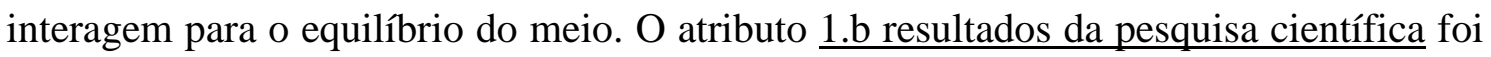
percebido tanto durante a visita - quando Laura diz: "É, agora eles tão vendo de fazer o sombreamento para ele não desenvolver ou remover o bambu" (turno 621) - quanto na entrevista - quando Maria diz "um pessoal que cuida do parque estava vendo como é que ia manter o controle" e, ainda na entrevista, quando Laura diz: "Eles estão estudando para ver como que eles vão fazer [...]". Um aspecto relevante foi que o fato de Laura e Maria perceberem que as estratégias de manejo estão em processo de estudo e investigação por 
pesquisadores, faz com que o atributo 1 .e. papel do pesquisador no processo de produção do conhecimento, previsto desde o início, fosse identificado.

Contudo, o atributo 1.f. evolução da ciência, embora não previsto no roteiro, foi identificado quando as visitantes reconhecem o trabalho desenvolvido pelos pesquisadores e o caráter questionável e inacabado da ciência.

Com relação ao indicador institucional, identificamos o atributo $\underline{2 . b \text {. missão }}$ institucional como produtora e disseminadora de conhecimento científico, quando Laura afirma, por exemplo, que "[...] agora eles tão vendo de fazer o sombreamento". No caso do indicador estético/afetivo, identificamos o atributo $\underline{4 . b}$ possibilidade de interação e contemplação dos elementos da exposição, já que as falas estão sendo apoiadas pelas leituras e observações feitas ao longo da trilha. Além disso, o envolvimento com o tema, associadas com a fala de Maria sobre ser "interessante", dão vasão ao atributo 4.c. motivação do público no envolvimento com o tema exposto.

No quadro abaixo, sintetizamos os indicadores e atributos e as habilidades investigativas consideradas na produção do roteiro e aqueles observados ou ausentes na visita e na entrevista.

Quadro 5 - Síntese dos Indicadores de Alfabetização Científica, Atributos e Habilidades Investigativas relacionados ao quadro 02 do roteiro

\begin{tabular}{|c|c|c|c|}
\hline Indicadores-Atributos/Habilidades & $\begin{array}{l}\text { Antes/na } \\
\text { produção do } \\
\text { roteiro }\end{array}$ & $\begin{array}{l}\text { Durante a } \\
\text { visita }\end{array}$ & $\begin{array}{l}\text { Após a } \\
\text { visita/entrevista }\end{array}$ \\
\hline \multicolumn{4}{|l|}{ Indicador Científico (1): } \\
\hline 1.a Conceitos científicos e suas definições; & $\mathrm{X}$ & - & $\mathrm{X}$ \\
\hline 1.b Resultados da pesquisa científica; & $\mathrm{X}$ & $\mathrm{X}$ & $\mathrm{X}$ \\
\hline $\begin{array}{l}\text { 1.d. Construção de conhecimento a partir da } \\
\text { interação com o objeto/texto presente no } \\
\text { discurso expositivo; }\end{array}$ & $\mathrm{X}$ & $\mathrm{X}$ & $X$ \\
\hline $\begin{array}{l}\text { 1.e. Papel do pesquisador no processo de } \\
\text { produção do conhecimento. }\end{array}$ & $\mathrm{X}$ & $\mathrm{X}$ & $\mathrm{X}$ \\
\hline 1.f. Evolução da ciência & - & $\mathrm{X}$ & $\mathrm{X}$ \\
\hline \multicolumn{4}{|l|}{ Indicador Institucional (2): } \\
\hline $\begin{array}{l}\text { 2.b. Missão institucional como produtora e } \\
\text { disseminadora de conhecimento científico; }\end{array}$ & $\mathrm{X}$ & $\mathrm{X}$ & $\mathrm{X}$ \\
\hline \multicolumn{4}{|l|}{ Indicador Estético/Afetivo (4): } \\
\hline $\begin{array}{l}\text { 4.b. Possibilidade de interação e contemplação } \\
\text { dos elementos da exposição; }\end{array}$ & $\mathrm{X}$ & $\mathrm{X}$ & - \\
\hline $\begin{array}{l}\text { 4.c. Motivação do público no envolvimento com } \\
\text { o tema exposto }\end{array}$ & $\mathrm{X}$ & - & $\mathrm{X}$ \\
\hline \multicolumn{4}{|l|}{ Habilidades Investigativas: } \\
\hline Observação & $\mathrm{X}$ & $\mathrm{X}$ & - \\
\hline Afirmação & - & $\mathrm{X}$ & - \\
\hline Explicação & $\mathrm{X}$ & $\mathrm{X}$ & $\mathrm{X}$ \\
\hline Emissão de Opinião & - & $\mathrm{X}$ & $\mathrm{X}$ \\
\hline
\end{tabular}


III) Eixo temático: Árvores mantidas ao longo do percurso (quadro 3)

Figura 17:Recorte do quadro 3 do roteiro

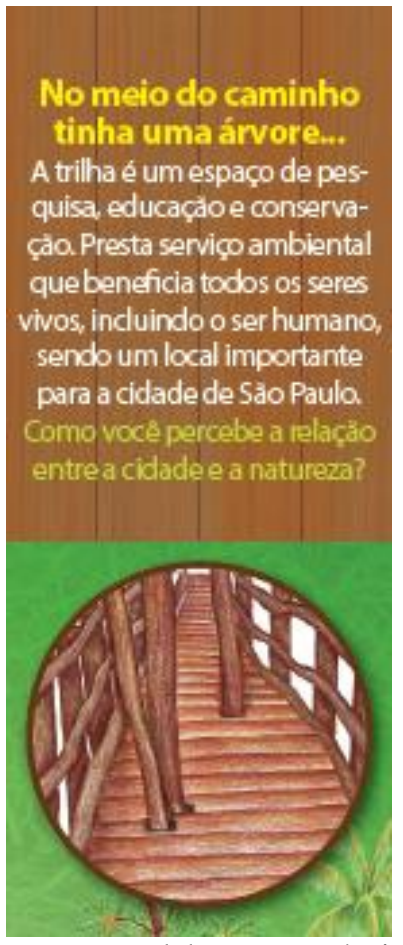

Fonte: elaboração própria

\section{III.1) Informações Gerais}

* Imagem: desenho de árvores emergindo do trajeto da trilha.

* Subtítulo11: No meio do caminho tinha uma árvore...

* Texto complementar ao subtítulo: $A$ trilha é um espaço de pesquisa, educação $e$ conservação. Presta serviço ambiental que beneficia todos os seres vivos, incluindo o ser humano, sendo um local importante para a cidade de São Paulo.

* Texto Principal: Como você percebe a relação entre a cidade e a natureza?

\section{III.2) Indicadores e atributos de AC e habilidades investigativas usadas na produção do roteiro:}

Pelo caráter informativo do texto, o indicador científico se faz presente com a definição de "serviço ambiental", que traz consigo o atributo $\underline{\text { 1.a conceitos científicos e }}$

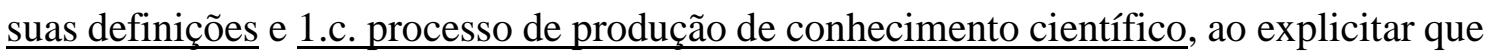
"a trilha é um espaço de pesquisa". Esses dois atributos reforçam a presença do atributo $\underline{1 . b}$ resultados da pesquisa científica. Nesse sentido, também se considerou no roteiro o atributo 1 .d. construção de conhecimento a partir da interação com o objeto/texto presente no discurso expositivo, a partir da interação entre o texto do roteiro e os elementos da trilha.

\footnotetext{
${ }^{11}$ Subtítulo inspirado no poema "No meio do caminho" de Carlos Drummond de Andrade publicado em 1928 na Revista Antropofagia, de São Paulo.
} 
A ilustração, o subtítulo e a reflexão proposta no texto principal remetem aos seguintes indicadores: indicador institucional, interface social e estético/afetivo. Esses indicadores conjuntamente com a ilustração do quadro 3, presente neste eixo, teve intenção de favorecer o atributo 2.a. importância das coleções mantidas pela instituição ao ilustrar a manutenção de árvores ao longo do trajeto. O subtítulo e o texto complementar chamam atenção para a importância desse local na cidade de São Paulo não somente por ser um espaço de pesquisa, educação e conservação (referente ao atributo 2.b. missão institucional como produtora e disseminadora de conhecimento científico), mas também por prestar serviço ambiental que beneficia todos os seres vivos. O texto do quadro 3 privilegia indicador interface social, no atributo $\underline{\text { 3.c. aplicação social do }}$ conhecimento científico, já que relaciona a temática expositiva ao cotidiano e à percepção da cidade e da natureza possibilitando reflexões sobre as relações entre a ciência e as questões sociais, econômicas e ambientais, por exemplo. Com relação ao indicador estético afetivo, o roteiro considerou os atributos $\underline{4 . a .}$ expressão de sentimentos, 4.b. possibilidade de interação e contemplação dos elementos da exposiçãa e $\underline{4 . c . ~ m o t i v a c ̧ a ̃ o ~}$ do público no envolvimento com o tema exposto, pois visam instigar o visitante à observação e à percepção do ambiente ao seu redor e pelo fato de que manter árvores no percurso permite aos visitantes tocá-las, isto é, interagir com os objetos da exposição.

Do ponto de vista das habilidades investigativas, o roteiro buscou, neste eixo, estimular a observação do trajeto da Trilha para reflexão e a proposição de explicações sobre a importância deste ecossistema para a cidade de São Paulo. Já a existência das árvores no meio do trajeto pode levar o visitante a tecer relações entre a cidade e a natureza, por conseguinte, promover a emissão de opinião e conclusões.

\section{III.3) Indicadores, atributos e habilidades expressos pelos visitantes:}

Em três momentos da visita Laura chama a atenção da filha para o fato da árvore ser mantida ao longo do trajeto, tema central deste terceiro eixo do roteiro: no turno 18: "Olha, Antônia, a árvore ficou no meio do caminho"; no turno 41: "Viu que não pode cortar árvore? [...] fica em volta" (referindo-se ao trajeto da trilha ser recortado para desviar da árvore); posteriormente, quando Antônia aponta para a árvore no percurso, Maria novamente reforça a ideia: "Viu? Não pode cortar as árvores" (turno 76). Esta última observação desencadeia uma conversa sobre a importância de manutenção das árvores que vai do turno 77 ao 87: 
Vi. Por que elas crescem lá no alto (Antônia, turno 77)

Olha essa que grandona ((referindo-se a uma árvore)), ela dá toda a volta. Ó que grandona! (Laura, turno 78)

\section{É (Antônia, turno 79)}

Cê vê como ela é bem alta? Você consegue pegar? Lá, ó, onde ela chega?" (Maria, turno 80)

Você viu? (Laura, turno 81)

Mãe, sabe por que não pode cortar as árvores? (Antônia, turno 83)

Por quê? (Laura, turno 84)

Porque o macaco cai triste se tiver onde está cortando a casa (Antônia, turno 85)

Isso mesmo, a casa do macaquinho é na árvore. Não pode cortar (Laura, turno 86)

É. Não pode cortar a árvore. A árvore é feita pros macaquinhos (Antônia, turno 87)

Figura 18: Família discutindo sobre a árvore mantida no percurso

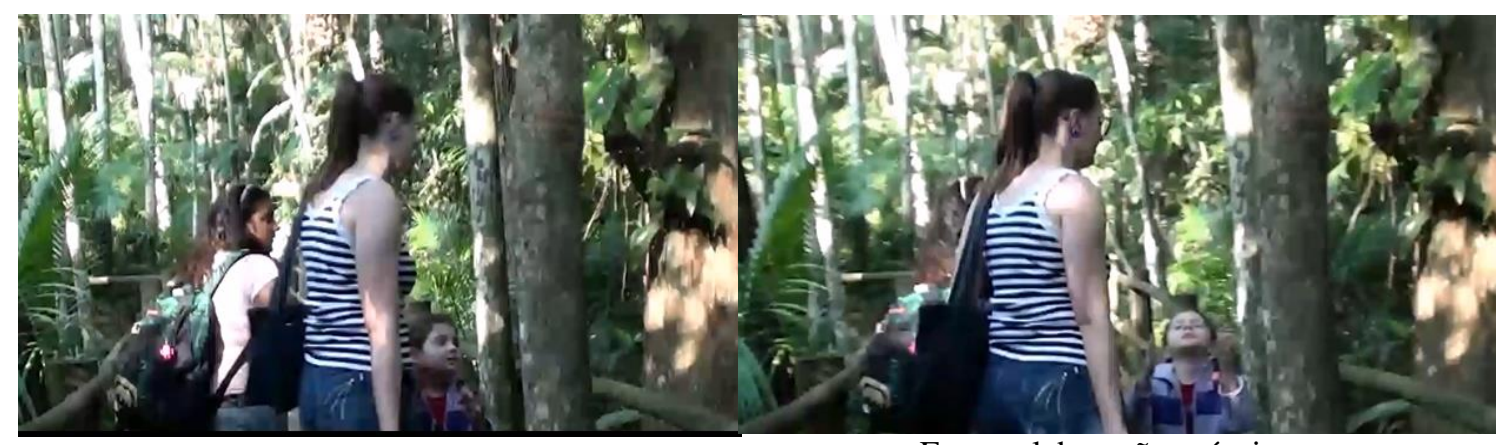

Fonte: elaboração própria

Fonte: elaboração própria

Ao ser indagada sobre o papel e importância da Trilha da Nascente na entrevista, Maria fala sobre a sua percepção em relação à exposição midiática comumente dada ao tema "água”, as possibilidades de uso, o atual panorama de escassez de água potável e sobre a necessidade de maior conhecimento para a preservação:

[...] a gente ouve falar que tem muito rio poluído, como o rio Pinheiros, o rio Tietê, mas a nascente deles dá para você nadar, dá para você beber água, e as pessoas não sabem disso, a gente sabe pela televisão, às vezes, quando, que nem, quando, agora, estava até brincando com ela, que objeto de luxo, hoje, é ter água, por conta dessa falta de água, da falta de chuva e tal. E mostrar isso para a criança também é bacana, que nem eu falei para ela, "é aqui que nasce o rio". A criança nem sabe que o rio tem uma origem, que nem ela teve. Então é legal, a gente viu os sapinhos, mostrou pra ela, ó, até a gente conseguiu achar um sapo maior 
e os filhotinhos, "ó, está vendo? O sapo nasce desse jeito, tal". Então a origem das coisas é muito legal, a gente saber até para a preservação, porque às vezes as pessoas não sabem. Que nem, a gente encontrou muito lixo e eles não sabem que ele prejudica a natureza e, se prejudicar a natureza, futuramente vai nos prejudicar, só que eles não têm essa visão que a gente precisa ter, que é bem legal. (Maria)

Em seguida a pesquisadora pergunta por que que as visitantes acham que essa trilha pode ser importante para os munícipes e para a cidade de São Paulo. Laura argumenta que a visita neste espaço pode ter como objetivo educar e conscientizar o público sobre a importância da conservação da natureza e reforça a interdependência entre a vegetação da mata atlântica e a água da nascente para o equilíbrio ecológico do ecossistema com uma frase pertencente à placa 05 (Nascente) - conteúdo que também poderia ser enquadrado no quadro 07 do roteiro; assim como - quando diz "quem sujou fomos nós mesmos", ela trata de uma das possíveis formas de interação do homem na natureza, pertencente ao eixo temático do quadro 08 do roteiro:

Eu acho que tem, para eles se conscientizarem do, por exemplo, a gente vê sempre o rio sujo. Então, se os moradores de São Paulo viessem, olhassem, para eles verem que o começo dele não é sujo, quem sujou fomos nós mesmos. Eu acho importante, até a conscientização, tanto dos mais velhos como dos mais novos, para ver, justamente, a questão da origem, de como é na natureza. Que nem a placa lá falou, que "a mata protege a nascente e a nascente protege a mata". Eu acho muito importante, mas nem todos dão conta. (Laura)

Neste eixo temático, percebe-se a ocorrência de um diálogo mais extenso entre membros da família, tendo sido identificadas várias habilidades investigativas: observação do trajeto da trilha, que pode ser notada nas vezes em que Laura incita Maria a, com ela, observar as árvores mantidas ao longo do percurso (turnos 18, 41, 76, 78, 81); a emissão de opinião evidenciada quando Laura diz que não se pode cortar árvores - na visita (turnos 41, 76) e na sustentação das ideias levantadas por Laura e Maria no momento da entrevista; questionamento quando Antônia, no turno 83, pergunta à mãe em tom de incitação - se ela sabia por que não se pode cortar as árvores. Neste momento, Laura retorna à pergunta e Antônia explica que é "porque o macaco cai triste se tiver onde está cortando a casa" (turno 85), evidenciando esta habilidade investigativa. Há também a habilidade afirmação nos turnos 77, 79 quando Antônia concorda com a mãe de que não se pode cortar as árvores e confirma de que uma delas é realmente "grandona" e no turno 86 quando Laura afirma também que "a casa do macaquinho é na árvore”. O diálogo 
finaliza evidenciando a habilidade de conclusão, quando Antônia indica que "não pode cortar a árvore. A árvore é feita pros macaquinhos" (turno 87).

Quanto aos indicadores de Alfabetização Científica, ao relacionar a permanência das árvores à não derrubada da mata e discorrer sobre a manutenção de árvores como de fundamental importância para a vida arborícola dos bugios, as integrantes da família trazem à tona o indicador científico (1); sendo este um ecossistema a fala das visitantes demonstra que elas percebem que existe uma relação de interdependência onde a vida de um organismo (neste caso o bugio) está ligada à de outros (árvores). A partir desse pressuposto, as visitantes inferem que as árvores devam ser protegidas e não sujeitas à degradação pelo ser humano. E, embora não se possa aferir se entre os turnos 83 e 87 as visitantes se reportam ao conceito de preservação ou conservação ambiental, faz-se

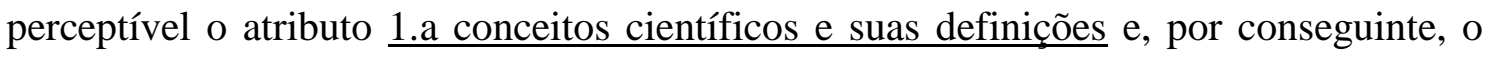
atributo $\underline{1 . d \text {. construção de conhecimento a partir da interação com o objeto/texto presente }}$ no discurso expositivo. Esses atributos foram também aferidos na entrevista: o primeiro subentendemos que ocorre quando Maria e Laura trazem o conceito de serviços ambientais de provisão com a fala "dá para você beber água", de recreação quando diz “dá para você nadar" e educacional ao dizer "[...] a conscientização, tanto dos mais velhos como dos mais novos, para ver, justamente, [...] como é na natureza", por exemplo. O segundo quando, para responder parte de uma questão que dizia respeito ao quadro 03 do roteiro, menciona uma frase da placa 05 e, tecendo relações com conteúdo dos quadros 07 e 08 do roteiro, reforçam a ideia de que a educação/conscientização ambiental favorece a preservação dos ecossistemas que, consequentemente, beneficia a existência humana.

$\mathrm{O}$ indicador institucional aparece de maneira implícita no diálogo durante a visita, quando as visitantes reconhecem que existe uma intenção de conservação das árvores (turnos 18, 41, 78). Na entrevista, Laura retoma essa ideia quando perguntada sobre o que mais gostou na visita, e destaca que foi “[...] das árvores no meio do caminho, que eles (funcionários do JB) não cortaram. Eu achei legal, eles construíram em volta a trilha". Desse modo, identifica-se em parte na visita e, confirmado na entrevista, o atributo 2.a. importância das coleções mantidas pela instituição quando as visitantes percebem o papel da instituição em manter o seu acervo.

Nota-se também que, nos turnos 18, 41, 76 a 91, a existência das árvores no percurso está relacionada ao indicador estético/afetivo pois desperta a atenção dos visitantes, evidenciando a presença do atributo: $\underline{4 . c . ~ m o t i v a c ̧ a ̃ o ~ d o ~ p u ́ b l i c o ~ n o ~}$ envolvimento com o tema exposto -, já que possibilita, além da contemplação, o toque 
nesses elementos que fazem parte da exposição e do roteiro e, por isso, reportando ao atributo $\underline{4 . b}$. possibilidade de interação e contemplação dos elementos da exposição que, neste caso, foi um dos destaques da resposta de Laura ao ser questionada, na entrevista sobre o que mais havia gostado na trilha, como indicado no parágrafo anterior. Ainda na entrevista, novamente esse atributo pode ser evidenciado quando, ao serem perguntadas sobre Antônia como acham que o ser humano pode se fazer presente nessa trilha, Laura responde que "pelo menos, eles não cortaram todas as árvores do caminho, mas tenho certeza que uma ou outra foi tirada fora do caminho pra fazer a trilha. E tem o lado bom, que a gente pode interagir".

Quadro 6 - Síntese dos Indicadores de Alfabetização Científica, Atributos e Habilidades Investigativas relacionados ao quadro 03 do roteiro

\begin{tabular}{|c|c|c|c|}
\hline Indicadores - Atributos / Habilidades & $\begin{array}{l}\text { Antes/na } \\
\text { produção do } \\
\text { roteiro }\end{array}$ & $\begin{array}{l}\text { Durante a } \\
\text { visita }\end{array}$ & $\begin{array}{l}\text { Após a } \\
\text { visita/entrevista }\end{array}$ \\
\hline \multicolumn{4}{|l|}{ Indicador Científico (1): } \\
\hline 1.a Conceitos científicos e suas definições & $\mathrm{X}$ & $\mathrm{X}$ & $\mathrm{X}$ \\
\hline 1.b. Resultados da pesquisa científica; & $\mathrm{X}$ & - & - \\
\hline $\begin{array}{l}\text { 1.c. Processo de produção de conhecimento } \\
\text { científico }\end{array}$ & $\mathrm{X}$ & - & - \\
\hline $\begin{array}{l}\text { 1.d. Construção de conhecimento a partir da } \\
\text { interação com o objeto/texto presente no discurso } \\
\text { expositivo; }\end{array}$ & $\mathrm{X}$ & $\mathrm{X}$ & $\mathrm{X}$ \\
\hline \multicolumn{4}{|l|}{ Indicador Institucional (2): } \\
\hline $\begin{array}{l}\text { 2.a. Importância das coleções mantidas pela } \\
\text { instituição. }\end{array}$ & $\mathrm{X}$ & $\mathrm{X}$ & $\mathrm{X}$ \\
\hline $\begin{array}{l}\text { 2.b. Missão institucional como produtora e } \\
\text { disseminadora de conhecimento científico; }\end{array}$ & $\mathrm{X}$ & - & - \\
\hline \multicolumn{4}{|l|}{ Indicador Social (3): } \\
\hline $\begin{array}{l}\text { 3.c. Aplicação social do conhecimento científico, } \\
\text { incluindo a conexão entre a temática expositiva e } \\
\text { o cotidiano, possibilitando tecer relações entre a } \\
\text { ciência e as questões sociais, históricas, políticas, } \\
\text { econômicas e ambientais. }\end{array}$ & $\mathrm{X}$ & - & - \\
\hline \multicolumn{4}{|l|}{ Indicador Estético/Afetivo (4): } \\
\hline 4.a. Expressão de sentimentos & $\mathrm{X}$ & - & \\
\hline $\begin{array}{l}\text { 4.b. Possibilidade de interação e contemplação } \\
\text { dos elementos da exposição; }\end{array}$ & $\mathrm{X}$ & $\mathrm{X}$ & $\mathrm{X}$ \\
\hline $\begin{array}{l}\text { 4.c. Motivação do público no envolvimento com } \\
\text { o tema exposto }\end{array}$ & - & $\mathrm{X}$ & $\mathrm{X}$ \\
\hline \multicolumn{4}{|l|}{ Habilidades investigativas: } \\
\hline Observação & $\mathrm{X}$ & $\mathrm{X}$ & - \\
\hline Afirmação & - & $\mathrm{X}$ & - \\
\hline Explicação & $\mathrm{X}$ & $\mathrm{X}$ & - \\
\hline Questionamento & - & $\mathrm{X}$ & - \\
\hline Emissão de opinião & $\mathrm{X}$ & $\mathrm{X}$ & $\mathrm{X}$ \\
\hline Conclusão & $\mathrm{X}$ & $\mathrm{X}$ & - \\
\hline
\end{tabular}


IV) Eixo temático: Bugios (quadro 4)

Figura 19: Recorte do quadro 4 do roteiro

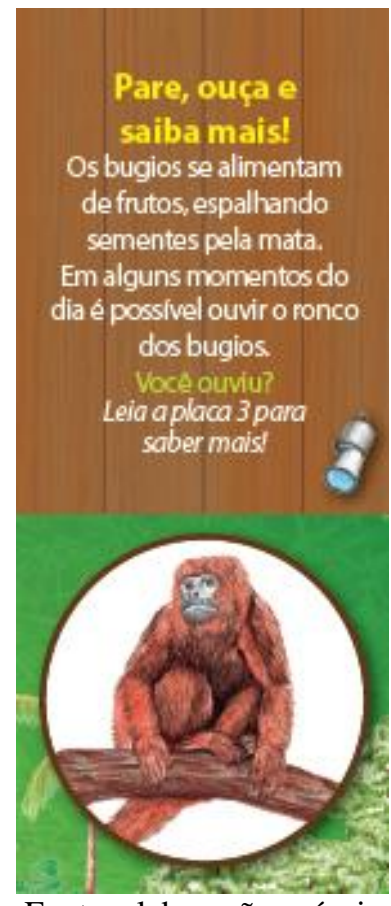

Fonte: elaboração própria

\section{IV.1) Informações Gerais}

* Imagem: desenho de um Bugio

* Subtítulo: Pare, ouça e saiba mais!

* Texto complementar ao subtítulo: Os bugios se alimentam de frutos, espalhando sementes pela mata. Em alguns momentos do dia é possível ouvir o ronco dos bugios.

* Texto Principal: Você ouviu?

* Texto Secundário: Para saber mais, leia a $3^{a}$ placa.

Figura 20: Imagem da Placa 03 - Bugios

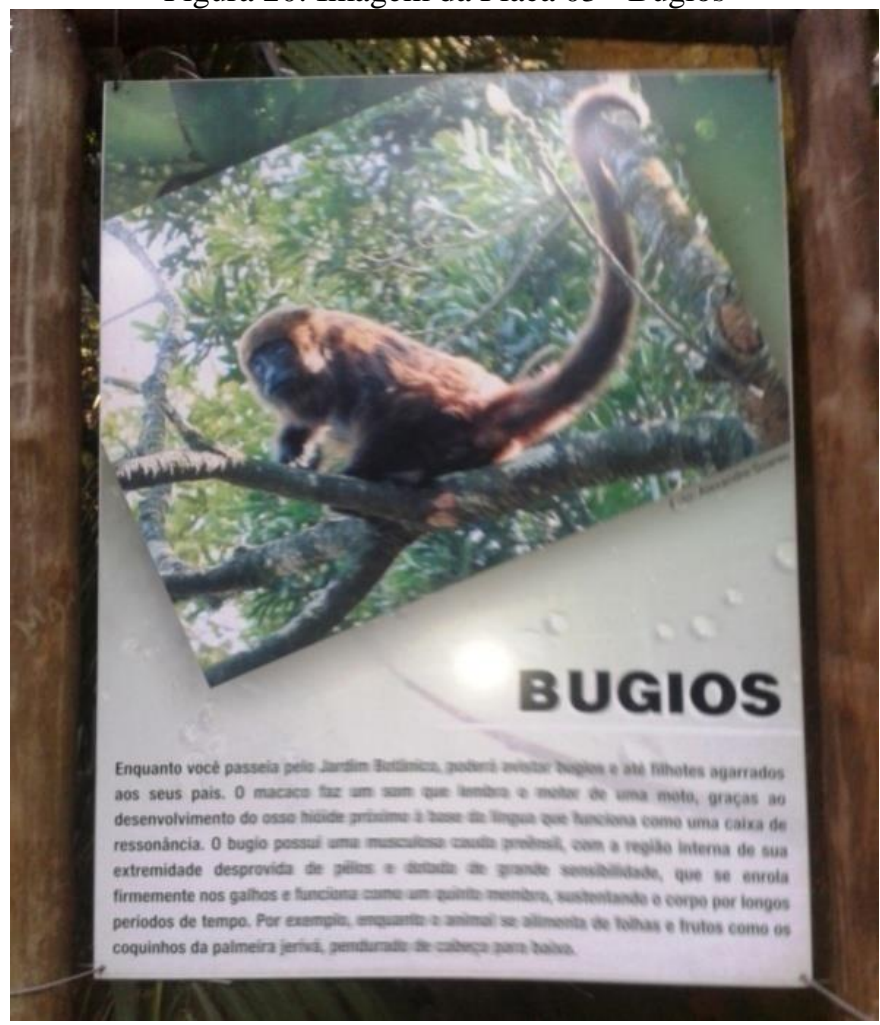

Fonte: elaboração própria 
Texto da Placa 3 - Bugios - Enquanto você passeia pelo Jardim Botânico, poderá avistar bugios e até filhotes agarrados aos seus pais. O macaco faz um som que lembra o motor de uma moto, graças ao desenvolvimento do osso hioide próximo à base da língua que funciona como uma caixa de ressonância. $\mathrm{O}$ bugio possui uma musculosa cauda preênsil, com a região externa de sua extremidade desprovida de pelos e dotada de grande sensibilidade, que se enrola firmemente nos galhos e funciona como um quinto membro, sustentando o corpo por um longo período de tempo. Por exemplo, enquanto o animal se alimenta de folhas e frutos, como os coquinhos da palmeira jerivá, pendurado de cabeça para baixo.

\section{IV.2) Indicadores e atributos de AC e habilidades investigativas usadas na produção do roteiro:}

Os textos e a imagem do quadro 4 do roteiro se apoiam e complementam as informações contidas na placa 3 da Trilha da Nascente, sobre o macaco bugio (Alouata guariba), e abordam aspectos como a vocalização - característica que atrai a atenção dos visitantes - e aspectos relacionados à alimentação deste animal para a manutenção da mata, por meio da dispersão de sementes. Dessa forma, por fornecer suporte à construção do conhecimento sobre os assuntos científicos expostos, esse quadro fomenta o indicador

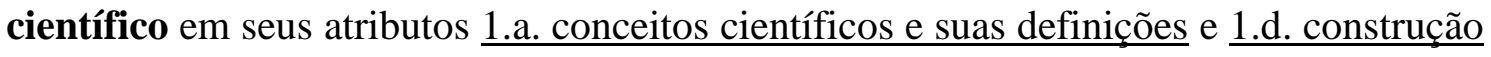
de conhecimento a partir da interação com o objeto/texto presente no discurso expositivo.

O subtítulo do quadro 4 do roteiro "Pare, ouça e saiba mais", associado a própria representação do macaco bugio no desenho, teve a função de estimular o indicador estético/afetivo nos atributos 4.c. motivação do público no envolvimento com o tema $\underline{\text { exposto e }} \underline{4 . b}$. possibilidade de interação e contemplação dos elementos da exposição. Além disso, a pergunta "Você ouviu?" pretende estimular o atributo $\underline{4 . a \text {. expressão de }}$ sentimentos.

Neste eixo temático tivemos a intenção de estimular as habilidades de observação do entorno da Trilha e a possibilidade de reconhecimento do animal e/ou da sua vocalização pelos elementos contidos no texto do roteiro, associado ao texto da placa 3 da Trilha. Além disso, ao a informação sobre a dispersão de sementes pelo bugio teve como intenção fornecer subsídios para a emissão de opinião sobre a pergunta do desafio.

Foi ainda nosso objetivo que as informações fornecidas subsidiassem o visitante a responder ao desafio proposto no roteiro: "Como as interações entre os elementos da natureza contribuem para o equilíbrio desse ambiente?". 


\section{IV.3) Indicadores, atributos e habilidades expressos pelos visitantes:}

Ao avistar o bando de bugios durante a visita, Maria chama a atenção de Antônia no turno 42 e consulta o roteiro para obter a informação sobre o nome popular da espécie de macaco ${ }^{12}$ que observava:

Olha lá o macaquinho, Antônia. Eu achei! Olha lá, um monte! Ali onde aquele homem está! Olha lá, olha lá, Antônia. Olha. Que bonitinho! É o macaquinho...deixa eu ver o nome desse macaquinho ((procurando a informação no roteiro)). Olha lá, olha. (Maria, turno 42)

Ao avistar, Antônia diz sussurrando: "Mãe! É o ma-ca-qui-nho!" (turno 43). Nos turnos que se seguem as visitantes fazem comentários sobre a observação dos bugios. No turno 50, Maria estimula Antônia a chamar os bugios “Aqui, ó, aqui, aqui ó. psiu, psiu. Chama o macaquinho: psiu, psiu. Vixe, tem um monte, amor, olha! Que lindo aqui! Psiu, psiu, chama ele. Faz assim que ele vê". Antônia tenta chamá-lo no turno 52 e então tenta imitar o ronco por eles evocados.

Em posse no roteiro e procurando encontrar a informação solicitada pela cunhada, Laura anuncia, no turno 54, o nome do animal: "Bugios". E, a fim de confirmar a informação com o que avistava, Maria pergunta, no turno 55 "os bugios são estes daqui?", olhando para o desenho do roteiro.

Nesta sequência de diálogos, vale também dizer que as visitantes observam e discorrem sobre a capacidade de preensibilidade da cauda dos bugios em se agarrar nos galhos das árvores, destacando assim elementos da terceira placa da trilha. Isso ocorre quando Antônia afirma no turno 56: "Sabe por que ele está de ponta cabeça? Porque ele segura ((com)) o rabo". Na continuidade - do turno 57 ao 60 -, Maria traz à tona informações sobre os hábitos alimentares dos bugios, as quais encontram-se no roteiro:

Sabe o que eles gostam de comer? Sabe o que eles gostam de comer? Eles gostam de comer frutinhas (Maria, turno 57)

Olha lá, tem um monte comendo (Laura, turno 58)

Frutinha vermelha, ó, aqui ó! (Maria, turno 59)

Um monte de frutinhas... (Laura, turno 60)

\footnotetext{
${ }^{12}$ A mata do Jardim Botânico de São Paulo abriga a espécie Alouatta guariba, que pode ser vista em vida livre nas árvores.
} 
Figura 21: Interação familiar e uso do monóculo para visualizar os frutos

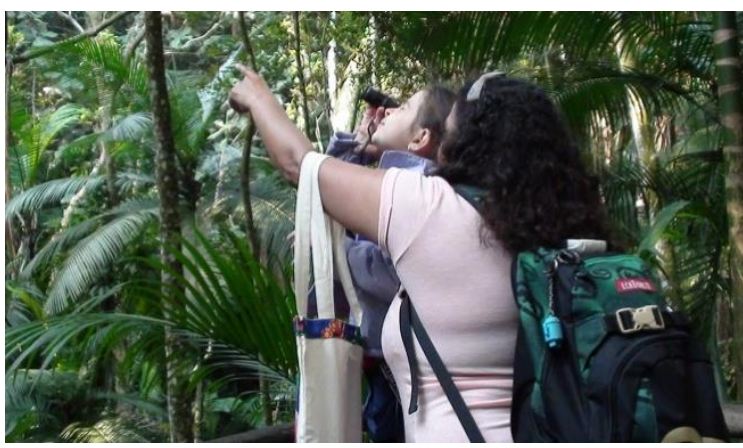

Fonte: elaboração própria

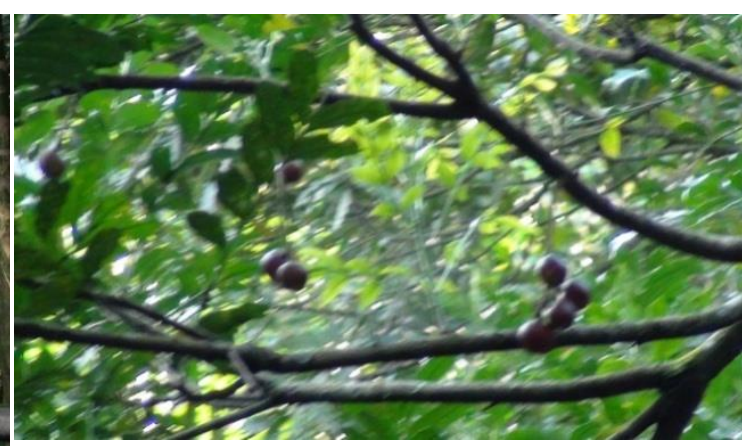

Fonte: elaboração própria

Posteriormente, nos turnos 403, 451 e 452, Maria e Laura retomam o tema da alimentação e fazem alusão ao papel destes primatas frugívoros como dispersores de sementes/frutos, sendo importantes na alimentação de outros animais terrestres:

$\mathrm{Na}$ verdade, ele come lá em cima; é que ele vai mexendo assim e algumas vai caindo, aí os bichinhos daqui que andam, os tatuzinhos que come o que cai no chão. Os tatuzinhos não sobem na árvore, eles são muito gordinhos pra subir. São como quati e não podem subir nas árvores, não consegue subir (Maria, turno 403).

As frutinhas que eles gostam. Caem no chão e ficam só as casquinhas. Essas bolinhas no chão ((apontando para sementes no chão da trilha)) (Laura, turno 451).

Maria: Olha aí, os coquinhos. É essa aqui, ó. Eles comem algumas e as outras caem no chão. São os coquinhos que tem lá naquelas árvores que eu falei pra você (Maria, turno 452). 
Figura 22: Maria mostrando para Antônia uma das sementes encontradas no percurso

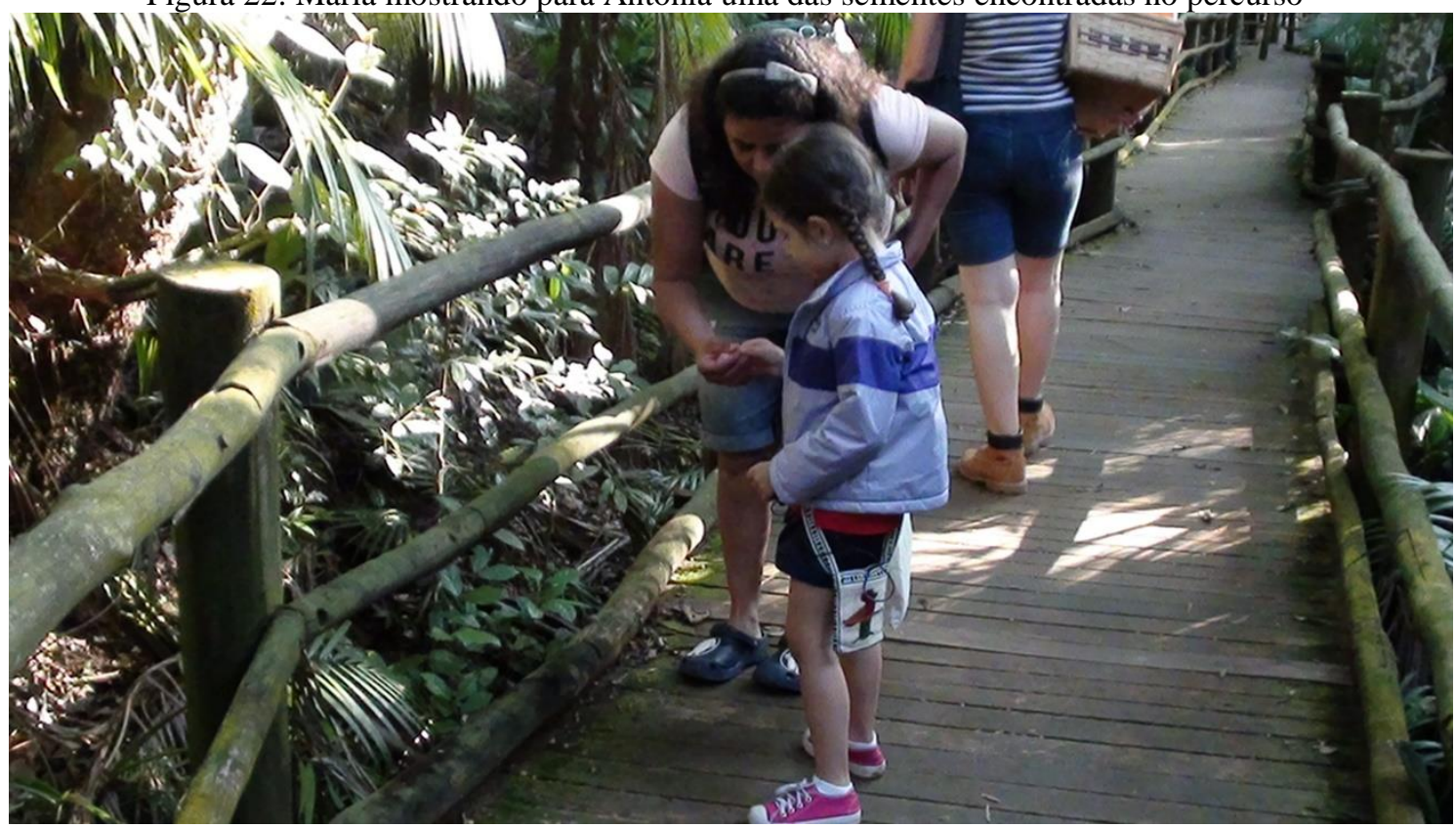

Fonte: elaboração própria

No meio deste diálogo, no turno 449, Laura pergunta à filha do que ela mais havia gostado e Antônia não hesita em dizer que gostou dos macacos. E ainda, no turno 548 Antônia chama seus familiares para prosseguir o percurso, mas sua tia Maria pede, no turno 549, que ela espere porque observa os bugios com o monóculo: "Peraí. Agora a gente tá vendo ele diferente!"’.

Figura 23: Observação dos bugios com monóculo

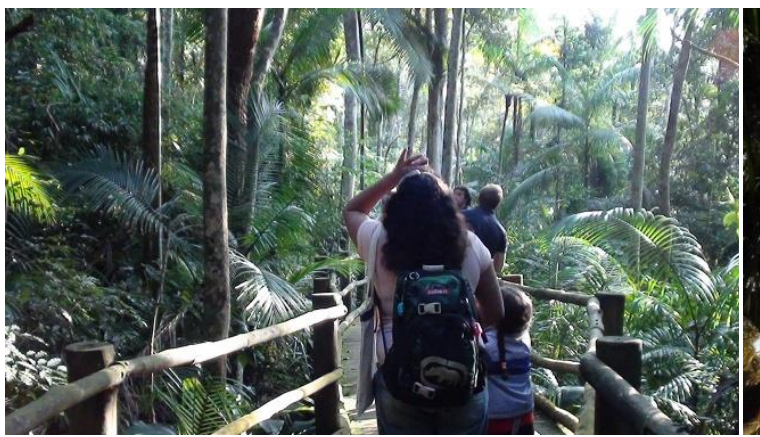

Fonte: elaboração própria

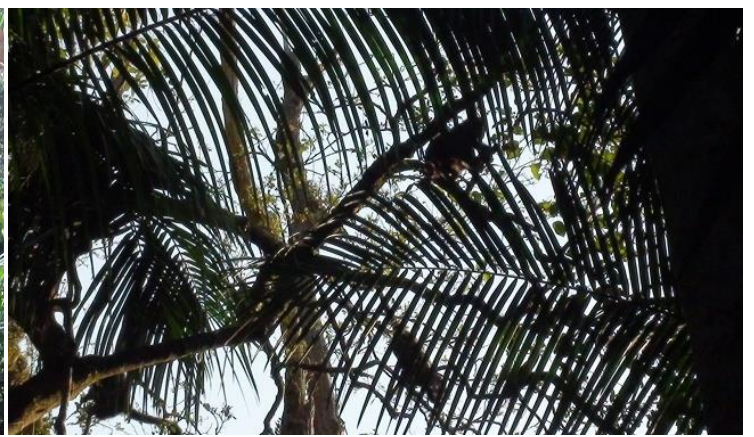

Fonte: elaboração própria

Os dados apresentados demonstram que a habilidade investigativa que mais se destacou entre os turnos 42 e 63, 161 e 165 e, mesmo depois, nos turnos 403, 449 ao 452, 536 ao 549 quando voltam a visualizar os bugios, foi a observação, reforçada pelo uso do monóculo por Maria. No turno 54, quando Laura informa o nome dos bugios, duas outras habilidades podem ser identificadas: afirmação e explicação. Baseada na sua observação 
e nas informações presentes no roteiro, Laura identifica o animal na exposição se certifica de seu nome, afirmando-o para o restante do grupo e esclarecendo o questionamento de sua cunhada. No turno 55, por sua vez, Maria compara os bugios vistos na mata com as ilustrações presentes no roteiro: “Os bugios são estes daqui?”. Há, ainda, no turno 57, a identificação da habilidade de questionamento quando Maria pergunta se alguém sabe o que os bugios gostam de comer e, em seguida, afirma que são as frutinhas vermelhas que observa. Também identificamos as habilidades indicadas na fala de Antônia, quando questiona e busca dar explicação à funcionalidade da cauda preênsil no corpo do bugio (turno 56). Ainda, quando Laura e Maria afirmam que os bugios (turnos 63 e 547) e o local com a presença deles (turno 50) são lindos, emitem opinião; assim como quando Antônia diz que o que mais gostou na visita foi ter visto os bugios.

Destacamos que algumas habilidades investigativas identificadas neste eixo temático não estavam previstas inicialmente no roteiro. A comparação foi uma delas e verificamos que ela foi promovida pelo fato da ilustração do bugio estar no roteiro. Além disso, o fato desta ilustração ser realista, ou seja, com intenção de produzir uma representação próxima ao real, possibilitou ainda mais a manifestação desta habilidade. Outras habilidades não previstas, mas já mencionadas foram: afirmação, questionamento e explicação; para estes casos, entendemos que o fascínio pela visualização dos bugios foi um potencializador de diálogos entre a família e, por consequência, de busca de informações, de manifestação de ideias e opiniões.

Identificamos na visita o indicador científico nos seus atributos: $\underline{1 \text {.a. conceitos }}$

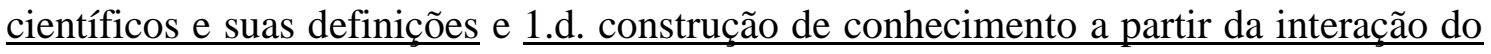
objeto/texto presente no discurso expositivo, neste eixo temático do roteiro. Nos diálogos estabelecidos, as visitantes procuram informações para identificar a espécie de macaco observada e obtiveram o dado sobre seu nome popular lendo o roteiro. Também expressam em suas falas aspectos sobre a cauda preênsil, a alimentação e o comportamento do animal.

Além disso, identificamos a presença do indicador estético/afetivo de forma intensa quando a família encontrou o bando de bugios. Embora estes animais estivessem presentes no roteiro, compõem parte da biodiversidade sazonal da área, e, dessa forma, nem sempre são observados. Entre os turnos 449 e 450, a experiência de observar os bugios foi marcante, por exemplo quando a Laura, ainda na Trilha, pergunta para Antônia do que ela mais havia gostado: 
A gente não vai embora ainda. Tem um monte de coisa pra ver. Me fale uma coisa: o que mais você gostou? (Laura, turno 449)

Eu gostei do macaco; o-u-u ((imita o ronco dos bugios)) (Antônia, turno 450)

Antônia retomou essa ideia na entrevista:

O que você mais gostou nessa trilha, Antônia? (Pesquisadora)

Dos macacos (Antônia)

Você já tinha visto algum macaco um dia na sua vida?

((gesticula negativamente)) (Antônia)

É a primeira vez que você vê macaco, ao vivo é (Laura)

A experiência de visualizá-los despertou grande mobilização e emoção na família, fato este que reporta aos atributos $\underline{4 . c . ~ m o t i v a c ̧ a ̃ o ~ d o ~ p u ́ b l i c o ~ n o ~ e n v o l v i m e n t o ~ c o m ~ o ~ t e m a ~}$ $\underline{\text { exposto e }}$ 4.b. possibilidade de interação e contemplação dos elementos da exposição. Assim que Maria ao avistar o bando, mostrou-os à Antônia, com entonação de voz pulsante e caracterizando-o como "bonitinho" (turno 53), da mesma forma no momento de prosseguir a visita (turno 547) quando afirmou "Coisinha mais linda!", são falas que podem ser associadas ao atributo 4.a. expressão de sentimentos.

Quadro 7 - Síntese dos Indicadores de Alfabetização Científica, Atributos e Habilidades Investigativas relacionados ao quadro 04 do roteiro

\begin{tabular}{|c|c|c|c|}
\hline Indicadores - Atributos / Habilidades & $\begin{array}{l}\text { Antes/na } \\
\text { produção do } \\
\text { roteiro }\end{array}$ & $\begin{array}{l}\text { Durante a } \\
\text { visita }\end{array}$ & $\begin{array}{c}\text { Após a } \\
\text { visita/entrevista }\end{array}$ \\
\hline \multicolumn{4}{|l|}{ Indicador Científico (1): } \\
\hline 1.a. Conceitos científicos e suas definições & $\mathrm{X}$ & $\mathrm{X}$ & - \\
\hline $\begin{array}{l}\text { 1.d. Construção de conhecimento a partir da } \\
\text { interação com o objeto/texto presente no } \\
\text { discurso expositivo; }\end{array}$ & $\mathrm{X}$ & $\mathrm{X}$ & - \\
\hline \multicolumn{4}{|l|}{ Indicador Estético/Afetivo } \\
\hline 4.a. Expressão de sentimentos & $\mathrm{X}$ & $\mathrm{X}$ & - \\
\hline $\begin{array}{l}\text { 4.b. Possibilidade de interação e contemplação } \\
\text { dos elementos da exposição }\end{array}$ & $\mathrm{X}$ & $\mathrm{X}$ & - \\
\hline $\begin{array}{l}\text { 4.c. Motivação do público no envolvimento } \\
\text { com o tema exposto }\end{array}$ & $\mathrm{X}$ & $\mathrm{X}$ & $\mathrm{X}$ \\
\hline \multicolumn{4}{|l|}{ Habilidades investigativas: } \\
\hline Observação & $\mathrm{X}$ & $\mathrm{X}$ & - \\
\hline Afirmação & - & $\mathrm{X}$ & - \\
\hline Comparação & - & $\mathrm{X}$ & - \\
\hline Explicação & - & $\mathrm{X}$ & - \\
\hline Questionamento & - & $\mathrm{X}$ & - \\
\hline Emissão de Opinião & $\mathrm{X}$ & $\mathrm{X}$ & $\mathrm{X}$ \\
\hline
\end{tabular}




\section{V) Eixo temático: Liquens (quadro 5)}

Figura 24: Recorte do quadro 5 do roteiro

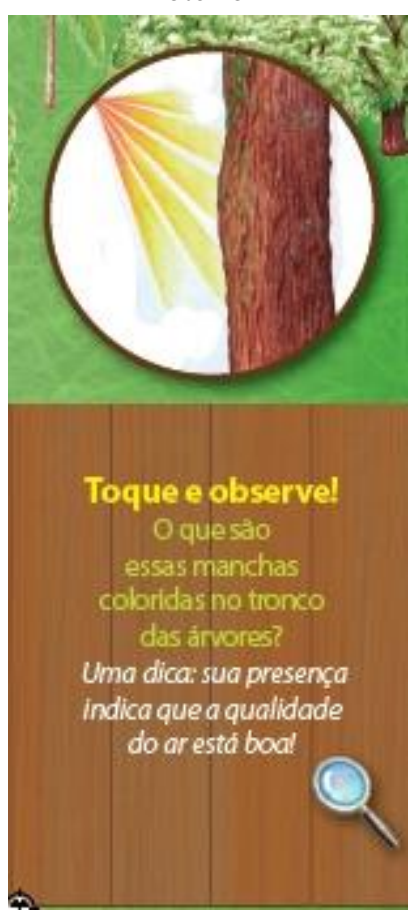

Fonte: elaboração própria

\section{V.1) Informações Gerais}

Imagem: Tronco com liquens.

* Subtítulo: Toque e observe!

* Texto Principal: O que são essas manchas coloridas no tronco das árvores?

* Texto Secundário: Uma dica: sua presença indica que a qualidade do ar está boa!

\section{V.2) Indicadores e atributos de AC e habilidades investigativas usadas na produção do roteiro:}

Nesse quadro 5 do roteiro foi intenção trabalhar com o Indicador Científico, principalmente no que diz respeito ao atributo $\underline{1 \text {.a. Conceitos científicos e suas definições, }}$ já que a pergunta “O que são essas manchas coloridas no tronco das árvores?" se reporta à definição de liquens e faz referência ao seu potencial bioindicador da qualidade do ar. Vale também dizer que imagem também reforça o Indicador Científico ao representar as diferentes cores dos liquens, demonstrar um jogo de luz/sombra por meio da ilustração de feixes de luz solar incidentes no lado oposto do tronco com a intenção de destacar esse organismo.

Vale destacar que o subtítulo "toque e observe", assim como o texto principal em forma de pergunta e a presença da ilustração, visam estimular o Indicador Estético/Afetivo (4) com a 4.a. expressão de sentimentos a partir da interação com a exposição: apreço, prazer, repulsa, indignação, sensações, entre outras, em relação aos fenômenos científicos e aos elementos naturais, 4 4.c. motivação do público no 


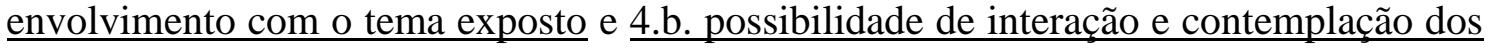
elementos da exposição através do "toque".

Em relação às habilidades investigativas, por meio imagens e do subtítulo deste quadro, procura-se estimular a observação dos liquens nos troncos das árvores da Trilha e, com o texto principal, emissão de opinião e explicação.

\section{V.3) Indicadores, atributos e habilidades expressos pelos visitantes:}

Maria repara no grupo vegetal de liquens dispostos no tronco de uma árvore, pergunta à Laura se ela sabe com o que se parece (turno 171) e, no turno 173, faz analogia à doença vitiligo.

Quando a sobrinha Antônia diz que uma mancha vermelha próxima é tinta, Maria consulta o roteiro no intuito de encontrar o nome para o que estava observando, mas só vê a informação de que a presença daquelas manchas "indicam boa qualidade do ar" e sugere no turno 185 que, por haver essa indicação, a árvore "tem saúde":

Aqui é um vermelho, é tinta ó (Antônia, turno 176)

É, na verdade, aqui no vermelho... ((abre e procura a informação no roteiro)) tá falando que é boa qualidade do ar. Vamos ver esse negócio vermelho? Tem uma lupa que dá pra ver. Peraí, dá pra ver a qualidade do ar aqui, ó, no negocinho vermelho (Maria, turno 177)

Aqui (Antônia, turno 178)

Calma, deixa a tia pegar aqui a lupinha. Que legal! (Maria, turno 179)

É pra nós duas? (Antonia, turno 180)

É. Mas vai usar só uma, senão você cai lá dentro, cai a lupa também (Maria, turno 181)

Ah, o vermelhinho ali é igual? (Laura, turno 182)

É (Maria, turno 183)

Vem cá, Antônia. (Laura, turno 184)

Aqui ((apontando para o roteiro)) tá falando que a bichinha ((referindose à árvore)) tem saúde. Que interessante! (Maria, turno 185) 
Figura 25: Maria observando o tronco de uma árvore com liquens.

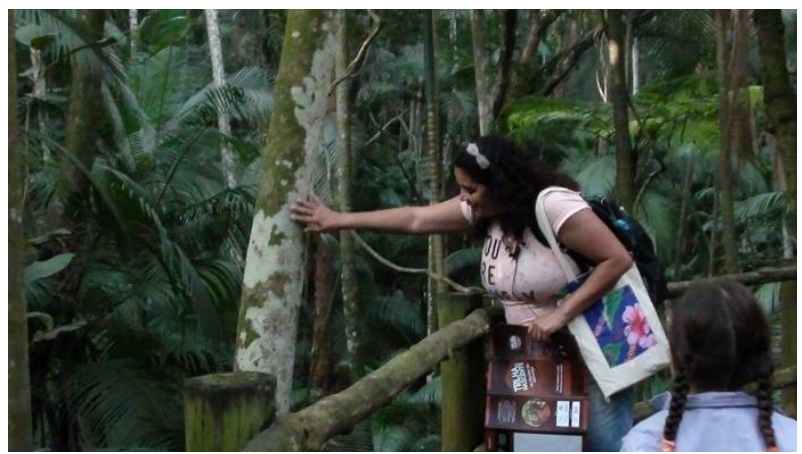

Fonte: elaboração própria, 2015

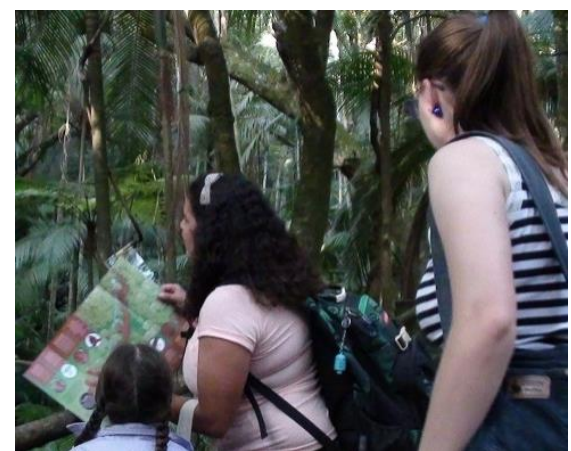

Fonte: elaboração própria

Nos turnos de 192 a 200 a Maria e Laura estimulam Antônia a olhar o tronco de árvore que está fora do trajeto da trilha. Para isso, seguram Antônia no corrimão de segurança da trilha e novamente lançam mão da lupa como instrumento de observação:

Calma, calma. A sua mãe não vai deixar você cair. É só você pra olhar isso aqui ó, esse vermelho, ó (Maria, turno 192)

É a qualidade do ar? (Laura, turno 193)

É. Está escrito aqui que é a qualidade do ar, significa que aqui, aqui (Maria, turno 194)

Aqui ó: O que são as manchas coloridas em torno das árvores? Diga! Tá aqui que é para olhar com a lupa (Maria, turno 197)

Ah, eu tô vendo agora (Antônia, turno 198)

Ah. Que legal (Laura, turno 199)

Tá escrito aqui ó: Sua presença indica que é a qualidade do ar está boa (Maria, turno 200)

Figura 26: Laura e Antônia observam o tronco de uma árvore com liquens com uma lupa..
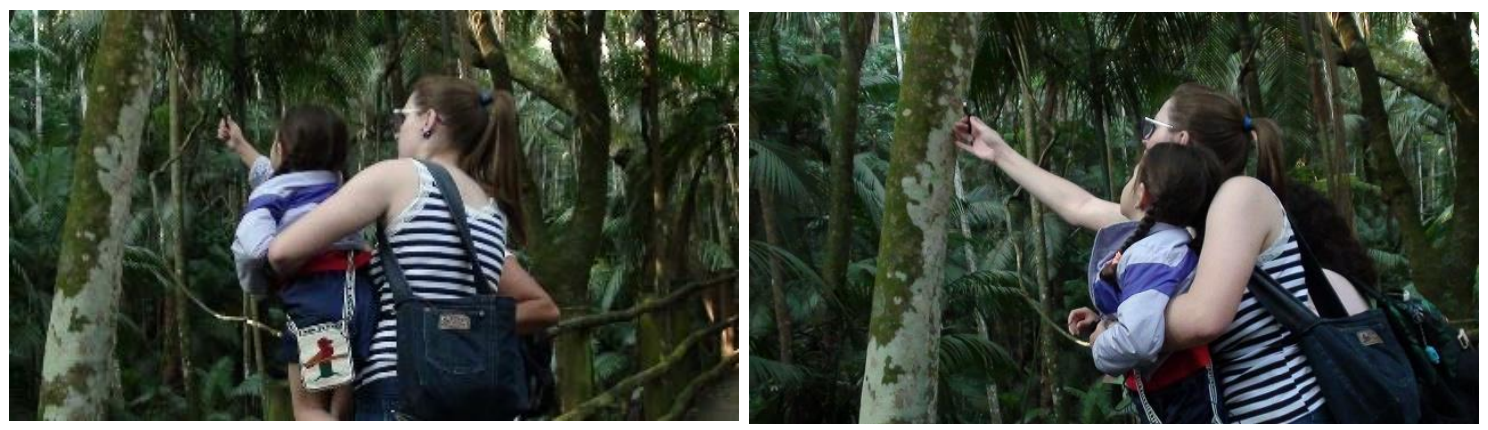

Fonte: elaboração própria 
Nota-se que esta habilidade investigativa mais recorrente nessa sequência de diálogos representativos (SDR) é a observação, que se torna ainda mais evidente com a utilização da lupa enquanto recurso proposto para tal. Nota-se, ainda, que a quantidade de turnos que fazem menção a este eixo temático é extensa e todas as outras habilidades se manifestam em algum momento nesta SDR: quando, no turno 171, Maria pergunta a Laura se ela sabia com o que aquela mancha se parecia, a visitante evidencia o questionamento como habilidade investigativa, já que elabora a pergunta sobre o objeto exposto (líquen) a fim de envolver e despertar a curiosidade dos demais integrantes da família.

Ao longo do percurso e das observações feitas nos liquens das árvores verifica-se que Maria busca interpretar o que está sendo observado, comparando as informações e evidências disponíveis no roteiro com o objeto exposto, e propondo explicações sobre o fenômeno. A partir de suas interpretações e do diálogo estabelecido com a tia e a mãe, emite opinião e conclui com base no exposto que aquelas árvores "têm saúde". Não possível afirmar que Maria tenha compreendido que os líquens são bioindicadores da qualidade do ar e que tenha verbalizado uma resposta correta à pergunta " $O$ que são essas manchas coloridas no tronco das árvores?". Também não era essa a nossa expectativa de resultado sobre o uso do roteiro na Trilha da Nascente, até porque não existe uma "resposta" na exposição ou no roteiro de maneira explícita. Por outro lado, entendemos que o roteiro promoveu um diálogo sobre as características e o papel dos liquens no ambiente, indo ao encontro do atributo $\underline{1 . d \text {. construção de conhecimento a partir da }}$ interação com o objeto/texto presente no discurso expositivo, pertencente ao Indicador

Científico (1). Este atributo também foi identificado na entrevista, quando perguntadas pela pesquisadora se os momentos de parada tinham relação com o roteiro e se elas tinham visto a indicação para a leitura das placas no roteiro:

Não, a gente viu. Que nem, que tinha uma árvore lá que eu achei legal, que ela tinha uns negócios vermelho, e ali ((no roteiro)) estava falando que fazia parte da respiração da árvore, ou seja, que aquela árvore tinha aqueles negócios vermelho, era que mostrava que ela estava com saúde. Eu achei interessante, porque se a gente não tivesse olhado o roteiro, a gente só ia bater, ver a árvore manchada (Maria)

É, via um monte de manchinhas, às vezes até achava que era coisa ruim... (Laura)

E ia embora. Mas aí, como a gente leu o roteiro antes, a gente viu que tinha umas manchinhas vermelhas e aí eu até expliquei para ela, eu mostrei com a lupa para ela ver direitinho, então foi bem diferencial, mesmo. (Maria) 
Essas manchas, que são coloridas, podem ser verdes, brancas, vermelhas, não importa; são os líquens, bioindicadores. Elas indicam que a qualidade do ambiente está boa. Na verdade, não é que é ela ajuda a árvore respirar, ela ajuda a gente, que está de fora, a saber que este é um ambiente saudável. Então, quando eles estão aqui, eles ajudam a gente a identificar que o ambiente está em equilíbrio. (Pesquisadora)

Legal! (Laura)

Percebemos que as falas na entrevista trazem como habilidades investigativas explicação e emissão de opinião.

Nota-se que Maria ficou com uma ideia errada do ponto de vista conceitual sobre o papel dos liquens relacionando-o com a respiração da árvore. Esta informação se revelou na entrevista havendo a possibilidade de a pesquisadora esclarecer as visitantes sobre o assunto. Posteriormente, ainda na entrevista, as visitantes contam ter sido marcante relacionar as "manchas" observáveis no tronco das árvores (líquens) e sua utilização como indicadores ambientais:

Teve algum detalhe que foi especialmente marcante, que vocês vão falar, "bom, vou levar isso para o resto da minha vida"? Algum conhecimento que vocês adquiriram e que vocês pensaram "nossa! eu não sabia disso"? (Pesquisadora)

Das manchinhas. (Laura)

As manchinhas foi marcante, mesmo. (Maria)

Nunca ia saber que aquilo era um indicador. (Laura)

Não, porque a gente passa batido, que nem, eu gostei, também, da parte que ele estava explicando que as árvores são aveludadas. Geralmente, quando a gente vai em parque, se não é esses parques específicos, a gente abraça, brinca com as árvores, mas não presta atenção. Mas aqui não, aqui as árvores, como é um jardim específico, tem umas árvores com uma tonalidade diferente. Além dessas manchinhas, eu gostei também de pegar nelas, que elas são meio aveludadas, nunca tinha visto uma árvore assim, parece um carpete. (Maria)

É algum tipo de musgo, não é? (Laura)

É isso, isso mesmo. (Pesquisadora)

Eles são muito fofos. (Laura)

Tem ali musgos e líquens. (Pesquisadora)

É, então, é o toque, você poder mexer, é legal. (Laura) 
Vale dizer que o entusiasmo das responsáveis por colocar Antônia no corrimão para observar os líquens e explicar o papel desses organismos ali mostra o engajamento da família com a exposição durante a visita e, durante a entrevista, ao dizer que visualizar estes organismos foi especialmente marcante sinalizam a presença do indicador estético/afetivo (4), sobretudo com o atributo 4.c. motivação do público no envolvimento com o tema exposto. Além de permitir a 4.a. expressão de sentimentos a partir da interação com a exposição, quando diz "legal", "são muito fofos", e 4.b. possibilidade de interação e contemplação dos elementos da exposição ("é o toque, você pode mexer").

Quadro 8 - Síntese dos Indicadores de Alfabetização Científica, Atributos e Habilidades Investigativas relacionados ao quadro 05 do roteiro

\begin{tabular}{|c|c|c|c|}
\hline Indicadores - Atributos / Habilidades & $\begin{array}{l}\text { Antes/na } \\
\text { produção do } \\
\text { roteiro }\end{array}$ & $\begin{array}{l}\text { Durante a } \\
\text { visita }\end{array}$ & $\begin{array}{l}\text { Após a } \\
\text { visita/entrevista }\end{array}$ \\
\hline \multicolumn{4}{|l|}{ Indicador Científico (1): } \\
\hline 1.a Conceitos científicos e suas definições & $\mathrm{X}$ & - & - \\
\hline 1.b. Resultados da pesquisa científica; & - & - & - \\
\hline $\begin{array}{l}\text { 1.d. construção de conhecimento a partir da } \\
\text { interação com o objeto/texto presente no } \\
\text { discurso expositivo }\end{array}$ & - & $\mathrm{X}$ & $\mathrm{X}$ \\
\hline \multicolumn{4}{|l|}{ Indicador Estético/Afetivo (4): } \\
\hline $\begin{array}{l}\text { 4.a. expressão de sentimentos a partir da } \\
\text { interação com a exposição }\end{array}$ & $X$ & $\mathrm{X}$ & $\mathrm{X}$ \\
\hline $\begin{array}{l}\text { 4.b. Possibilidade de interação } \\
\text { contemplação dos elementos da exposição; }\end{array}$ & $\mathrm{X}$ & $\mathrm{X}$ & $\mathrm{X}$ \\
\hline $\begin{array}{l}\text { 4.c. Motivação do público no envolvimento } \\
\text { com o tema exposto }\end{array}$ & $\mathrm{X}$ & $\mathrm{X}$ & $\mathrm{X}$ \\
\hline \multicolumn{4}{|l|}{ Habilidades investigativas: } \\
\hline Observação & $\mathrm{X}$ & $\mathrm{X}$ & - \\
\hline Comparação & - & $\mathrm{X}$ & - \\
\hline Explicação & $\mathrm{X}$ & $\mathrm{X}$ & $\mathrm{X}$ \\
\hline Questionamento & - & $\mathrm{X}$ & - \\
\hline Emissão de opinião & $\mathrm{X}$ & $\mathrm{X}$ & $\mathrm{X}$ \\
\hline Conclusão & - & $X$ & - \\
\hline
\end{tabular}

Fonte: elaboração própria 
VI) Eixo temático: Cacto espaguete (quadro 06)

Figura 27: Recorte do quadro 6 do roteiro

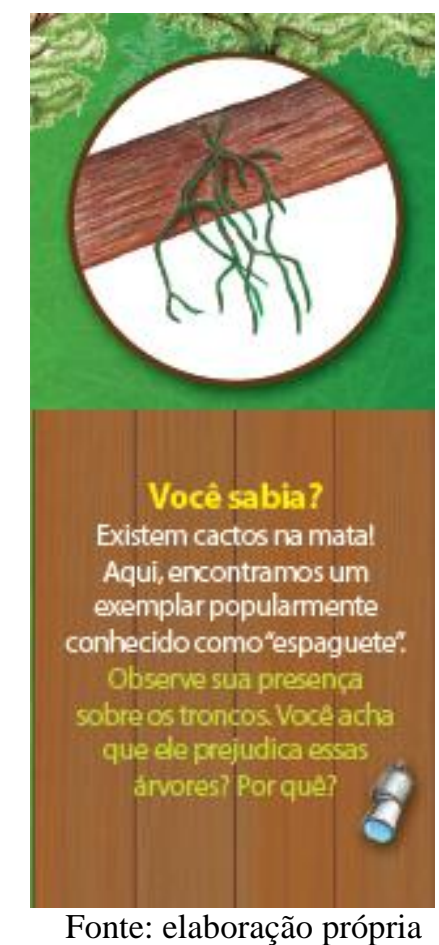

\section{VI.1) Informações Gerais}

* Imagem: Representação do Cacto.

- Subtítulo: Você sabia?

* Texto Principal: Existem cactos na mata! Aqui, encontramos um exemplar conhecido popularmente como "espaguete”.

* Texto Secundário: Observe sua presença sobre os troncos. Você acha que ele prejudica essas árvores? Por quê?

\section{VI.2) Indicadores e atributos de AC e habilidades investigativas usadas na produção do roteiro:}

Novamente o subtítulo é colocado em forma de pergunta para despertar a atenção do leitor e trazer no texto principal uma informação. Embora não traga o nome científico do cacto [Rhipsalisbaccifera (J. S. Muell.) Stearn], o roteiro faz referência a seu nome popular - cacto-macarrão ou cacto-espaguete, e, em conjunto com o texto secundário e os outros elementos do quadro, permitem a expressão dos atributos 1.a. conceitos $\underline{\text { científicos e suas definições }} e \underline{1 . d \text {. construção de conhecimento a partir da interação com }}$ o objeto/texto presente no discurso expositivo, do Indicador Científico.

O conjunto que compreende a imagem, subtítulo, texto complementar, principal e secundário procura estimular o indicador estético/afetivo nos atributos $\underline{4 . c \text {. motivação }}$ $\underline{\text { do público no envolvimento com o tema exposto, }}$, por meio da 4 .b. possibilidade de interação (ao facilitar a) contemplação dos elementos da exposição. Repare que o ícone correspondente à essa imagem é colocado de maneira ampliada à uma árvore.

Por meio dos textos e imagens deste quadro, procura-se estimular a observação dos cactos nos troncos das árvores da Trilha e, além de desmistificar a associação da 
imagem do cacto ao deserto, a ideia é convidar o visitante à reflexão e emissão de opinião de que se esse tipo de interação (epifitismo) é prejudicial para as árvores permitindo a elaboração de hipóteses, de explicação e de conclusões, habilidades importantes no processo de construção de argumentos.

\section{VI.3) Indicadores, atributos e habilidades expressos pelos visitantes:}

$\mathrm{Na}$ SDR sobre este tema, percebe-se que Maria aspira encontrar outro elemento trazido no roteiro: a cactácea Rhipsalis baccifera que é apresentada no quadro 6 do roteiro pelo seu nome popular, o "cacto espaguete":

Ó tem umas árvores que eu quero ver, que tem em nosso cabelo, tá dizendo que tem uns cachos na mata (Maria, turno 204)

Deixa eu vou ver? (Antônia, turno 205)

Aqui ó ((apontando para o quadro correspondente no roteiro)), a gente vai procurar aqui "uns lugar" que tenha cabelo igual ao nosso (Maria, turno 206)

Isso diz (Antonia, 207)

Repare que Maria diz que quer ver as árvores que possuem "cachos"; como a visitante não externalizou outros comentários, não há evidências que ela tenha refletido sobre o questionamento trazido no roteiro "você acha que ele prejudica essas árvores?" e, por conseguinte, se percebeu que se tratam de dois organismos de espécies distintas (árvore e cacto) que estabelecem interações ecológicas entre si. Essa informação é evidenciada na entrevista quando, ao serem questionadas sobre novas informações obtidas com o uso do roteiro, Maria responde que havia algumas árvores no roteiro "que eram diferentes [...] tinha os cachos".

Entre os turnos 383 e 387, Laura, Antônia e Maria observam o quadro 06 do roteiro:

Aqui que a gente viu isso aqui? Os cachos na mata? Não! Os "cactos" na matas! (Laura, turno 383)

Deixa eu ver (Antônia, turno 384)

Calma, calma! (Maria, turno 385)

Vamos ver se a gente acha. Ó, é aqui que a mamãe tem casa ((risos)).

Eu tenho num vaso (Laura, turno 386) 
Eu não vi isso daí (Maria, turno 387)

Por se tratar de uma espécie que apresenta como adorno principal longos ramos cilíndricos que pendem das hastes principais e formam uma cabeleira verde sobre troncos e galhos de árvores, Maria faz uma analogia dessa espécie de cactos com os seus cabelos e os interpreta como "cachos das árvores". No turno 383, Laura parece reproduzir a associação feita por Maria, mas ao observar o roteiro com mais cautela retifica a informação dizendo tratar-se de um cacto. Laura compara o elemento exposto à planta que possui em sua residência no turno 386 e reforça essa informação na entrevista. A pesquisadora esclarece na entrevista que o cacto está associado a uma árvore e demonstra um exemplar no local aos visitantes. Nesse momento, Laura percebe que não o cacto avistado não se trata da mesma espécie que ela possui em sua residência: "parece com a suculenta que eu tenho em casa, mas não é igual”.

Tendo em mente que era intenção desse quadro 06 do roteiro chamar a atenção dos visitantes para espécies de cactos passíveis de serem encontrados na Mata Atlântica, entendemos que as visitantes se debruçaram na identificação da cactácea por meio da análise da ilustração e das informações do texto do roteiro, o que nos remete ao atributo

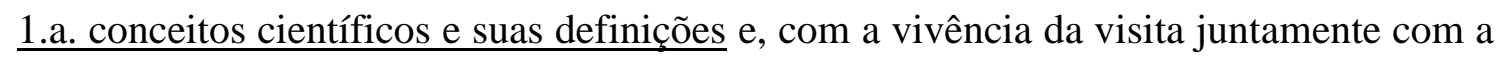
conversa da entrevista, aferimos que houve a 1.d. construção de conhecimento a partir da interação com o objeto/texto presente no discurso expositivo, atributo também do Indicador Científico.

O indicador estético/afetivo é identificado por permitir a 4.b. possibilidade de interação e contemplação dos elementos da exposição e, pelo fato de Maria explicitar o desejo de encontrar o elemento descrito no roteiro, demonstra o atributo $\underline{4 . c . ~ m o t i v a c ̧ a ̃ o}$ do público no envolvimento com o tema.

A observação foi a habilidade investigativa mais registrada nos turnos elencados e também ocorreu na entrevista quando a pesquisadora mostra um exemplar na mata. A comparação ocorre quando Laura compara o cacto ilustrado no roteiro à planta que possui na sua residência (turno 386 e entrevista) e quando Maria relaciona a ilustração do quadro 06 do roteiro aos seus cabelos (turnos 204 e 206). 
Quadro 9 - Síntese dos Indicadores de Alfabetização Científica, Atributos e Habilidades Investigativas relacionados ao quadro 06 do roteiro

\begin{tabular}{|c|c|c|c|}
\hline Indicadores - Atributos / Habilidades & $\begin{array}{l}\text { Antes/na } \\
\text { produção do } \\
\text { roteiro }\end{array}$ & $\begin{array}{c}\text { Durante a } \\
\text { visita }\end{array}$ & $\begin{array}{c}\text { Após a } \\
\text { visita/entrevista }\end{array}$ \\
\hline \multicolumn{4}{|l|}{ Indicador Científico (1): } \\
\hline 1.a Conceitos científicos e suas definições & $\mathrm{X}$ & $\mathrm{X}$ & - \\
\hline $\begin{array}{l}\text { 1.d. construção de conhecimento a partir da } \\
\text { interação com o objeto/texto presente no } \\
\text { discurso expositivo }\end{array}$ & $\mathrm{X}$ & $\mathrm{X}$ & $\mathrm{X}$ \\
\hline \multicolumn{4}{|l|}{ Indicador Estético/Afetivo (4): } \\
\hline $\begin{array}{l}\text { 4.b. Possibilidade de interação } \\
\text { contemplação dos elementos da exposição; }\end{array}$ & $X$ & $X$ & - \\
\hline $\begin{array}{l}\text { 4.c. Motivação do público no envolvimento } \\
\text { com o tema exposto }\end{array}$ & $X$ & $\mathrm{X}$ & - \\
\hline \multicolumn{4}{|l|}{ Habilidades investigativas: } \\
\hline Observação & $\mathrm{X}$ & $\mathrm{X}$ & $\mathrm{X}$ \\
\hline Comparação & - & $\mathrm{X}$ & - \\
\hline Explicação & $\mathrm{X}$ & - & $\mathrm{X}$ \\
\hline Emissão de opinião & $\mathrm{X}$ & - & - \\
\hline Conclusão & $\mathrm{X}$ & - & - \\
\hline
\end{tabular}

Fonte: elaboração própria

VII) Eixo temático: Interdependência entre a vegetação da mata atlântica e a água da nascente para o equilíbrio ecológico do ecossistema (quadro 7)

Figura 28: Recorte do quadro 7 do roteiro

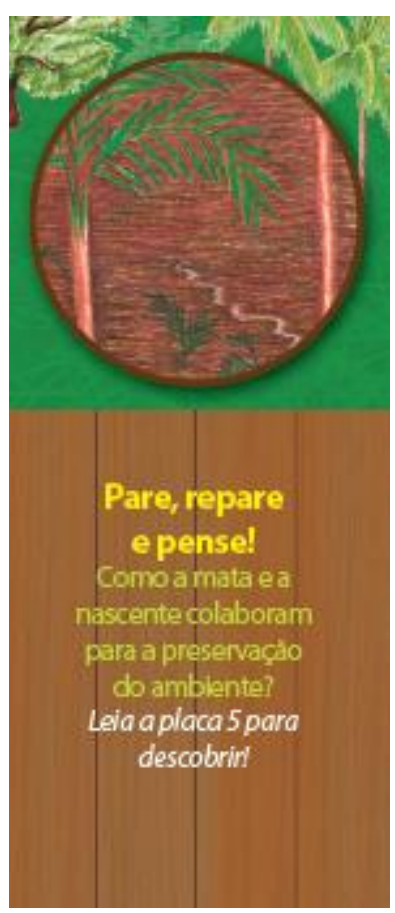

Fonte: elaboração própria

\section{VII.1) Informações Gerais}

Imagem: Representação da nascente do córrego Pirarungáua em meio à vegetação

* Subtítulo: Pare, repare e pense

* Texto Principal: Como a mata e a nascente colaboram para a preservação do ambiente?

* Texto Secundário: Leia a 5 placa da trilha para descobrir 


\section{VII.2) Indicadores e atributos de AC e habilidades investigativas usadas na produção do roteiro:}

No quadro 7 a representação da imagem da nascente nomeia e é ponto final da Trilha, cujo leito pode ser visto ao longo percurso. Ao nomear e representar a nascente do córrego no roteiro intencionamos que o atributo_1.a. conceitos científicos e suas definições fosse trazido à tona e esperava-se, em conjunto aos outros elementos que compõem este eixo temático, favorecer o atributo $\underline{1 \text {.d. construção de conhecimento a }}$ partir da interação com o objeto/texto presente no discurso expositivo, pertencente ao indicador científico (1).

Ao instigar a reflexão sobre relação entre a nascente e a mata para o equilíbrio desse ecossistema (texto principal), foi intenção dar destaque ao indicador institucional (2) no atributo 2.a. importância das coleções mantidas pela instituição e, ao propor parar, reparar e pensar sobre a questão proposta, o roteiro buscou destacar o indicador interface social (3) no que diz respeito ao atributo: $\underline{3 . c .}$ aplicação social do conhecimento científico, incluindo a conexão entre a temática expositiva e o cotidiano, possibilitando tecer relações entre a ciência e as questões sociais, históricas, políticas, econômicas e ambientais. Em especial, a resposta à questão “Como a mata e a nascente colaboram para a preservação do ambiente?" tem por finalidade levar a reflexão sobre a importância do Jardim Botânico estudar e promover a preservação da nascente e da mata. Além disso, ao incentivar a leitura da placa 5 da trilha pelo visitante, o roteiro destaca o atributo 3.e. posicionamento do público diante dos resultados da ciência já que no texto desta placa afirma-se que "qualquer interferência humana em uma dessas partes afetará as demais. Todos somos responsáveis pela proteção de nossos recursos naturais”, pois salienta a necessidade de um posicionamento dos indivíduos sobre a importância da conservação das florestas para a manutenção dos recursos hídricos.

Todos esses elementos em consonância com o subtítulo - que convida o visitante a parar, reparar (já que não existe uma placa indicando a localização da nascente) e pensar - e com a pergunta proposta neste quadro 7 ajudam também ao visitante a responder o desafio do roteiro "como os elementos presentes na Trilha interagem neste ambiente?”. Deste modo, previu-se na sua produção favorecer, além dos indicadores já citados, o indicador estético/afetivo (4) na 4.c. motivação do público no envolvimento com o tema exposto, por meio da 4.b. possibilidade de interação e contemplação dos elementos da exposição. 
Em relação às habilidades investigativas, esse quadro intenta estimular que o visitante observe a Trilha como um todo e reflita sobre os demais elementos trazidos até então no roteiro. Além disso, é importante que o visitante leia a placa 5 da Trilha para analisar e estabelecer conexões entre essa pergunta e o desafio proposto, já que estes possuem relação direta. Espera-se assim que o visitante proponha explicações para a interdependência entre mata e nascente, permitindo que ele possa emitir opinião e tirar conclusões para responder à pergunta do quadro e o desafio proposto.

Figura 29: Imagem da Placa 05 - Nascente

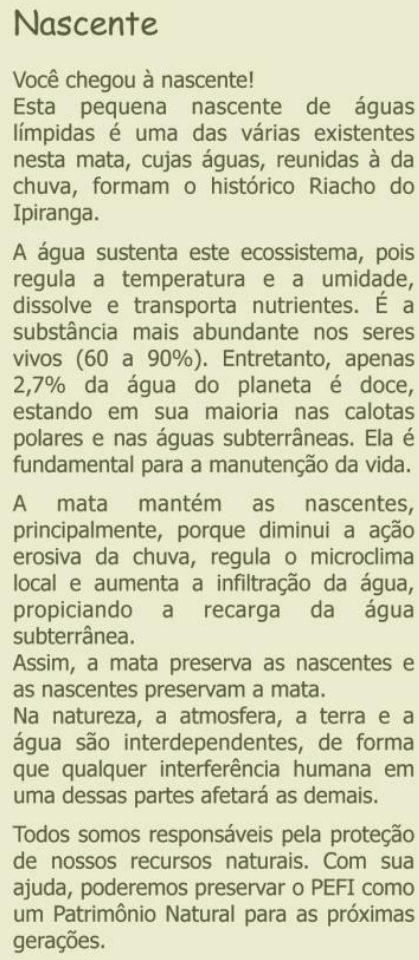

Nascente

Você chegou à nascente!

Esta pequena nascente de águas

límpidas é uma das várias existentes

nesta mata, cujas águas, reunidas à da

chuva, formam o histórico Riacho do Ipiranga.

A água sustenta este ecossistema, pois regula a temperatura e a umidade, dissolve e transporta nutrientes. É a substância mais abundante nos seres vivos (60 a $90 \%$ ). Entretanto, apenas $2,7 \%$ da água do planeta é doce, estando em sua maioria nas calotas polares e nas águas subterrâneas. Ela é fundamental para a manutenção da vida.

A mata mantém as nascentes, principalmente, porque diminui a ação erosiva da chuva, regula o microclima local e aumenta a infiltração da água propiciando a recarga da á subterrânea.

Assim, a mata preserva as nascentes e as nascentes preservam a mata.

Na natureza, a atmosfera, a terra e a água são interdependentes, de forma que qualquer interferência humana em uma dessas partes afetará as demais.

Todos somos responsáveis pela proteção de nossos recursos naturais. Com sua ajuda, poderemos preservar o PEFI como um Patrimônio Natural para as próximas gerações.

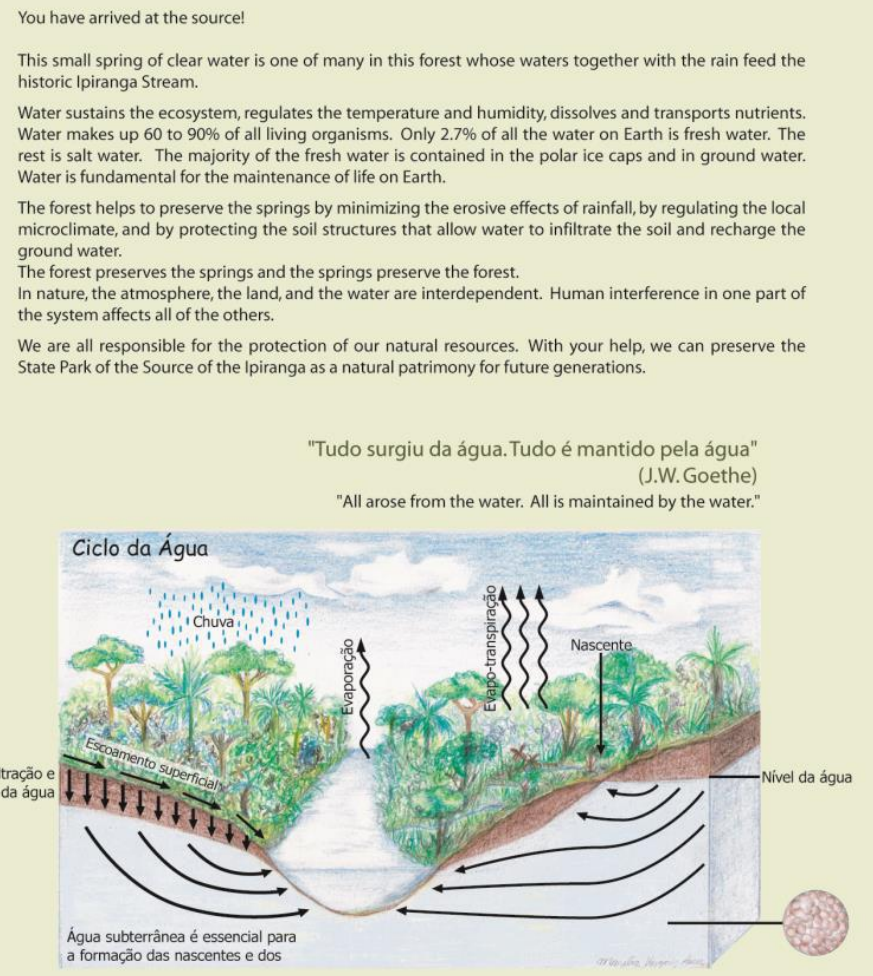

Fonte: Guia Pedagógico do Jardim Botânico de São Paulo ${ }^{13}$

Texto da Placa 5 - Nascente - Você chegou à nascente. Esta pequena nascente de águas límpidas é uma das existentes na mata, cujas águas, reunidas à da chuva, formam o histórico riacho Ipiranga. A água sustenta este ecossistema, pois regula a temperatura e a umidade, dissolve e transporta nutrientes. É a substância mais abundante nos seres vivos (60 a 90\%). Entretanto, apenas 2,7\% da água do planeta é doce, estando em sua maioria nas calotas polares e nas águas subterrâneas. Ela é fundamental para a manutenção da vida. A mata mantém as nascentes, principalmente, porque diminui a ação erosiva da chuva, regula o microclima local e aumenta a infiltração da água, propiciando a recarga da água subterrânea. Assim, a mata preserva as nascentes e as nascentes preservam a mata. Na natureza, a atmosfera, a terra e a água são interdependentes, de forma que qualquer interferência humana em uma dessas partes afetará as demais. Todos somos responsáveis pela proteção de nossos recursos naturais.

${ }^{13}$ Disponível em: http://www.ambiente.sp.gov.br/jardimbotanico/files/2013/08/guia-pedag\%C3\%B3gicodo-jardim-bot\%C3\%A2nico.pdf. 
Com sua ajuda, poderemos preservar o PEFI como um patrimônio natural para as próximas gerações.

\section{VII.3) Indicadores, atributos e habilidades expressos pelos visitantes:}

Ainda no início da visita, ao adentrar a Trilha, entre os turnos 34 e 40, Maria avista o Córrego Pirarungáua e estabelece uma relação deste com a nascente, associando-a ao abastecimento de água de um lago externo à trilha, mas que também é parte do Jardim Botânico.

Em momento posterior, mas ainda antes de chegar à nascente, as visitantes retomam a observação do córrego e, para tal, utilizam o monóculo:

Ó, continua, ó, da nascente do rio, tá vendo, ó? Aqui é onde riozinho nasce (Maria, turno 259)

É bem devagarinho (Laura, turno, 260)

É bem devagarinho! (Maria, turno 261)

Estão subindo, subindo, para ver onde ele nasce (Laura, turno, 262)

Olha, eu também. Consegue ver? Com o binóculo, com a luneta, né? Mãe! Quer ver no meu? É bem lá embaixo, olha lá (Antônia, turno 263)

Aham (Laura, turno 264)

Nos turnos 257 e 265, um pouco antes do fim da trilha, Maria chama atenção de Antônia para o som de água corrente da nascente. O reconhecimento dos diferentes sons presentes na trilha são um dos elementos relacionados na contracapa do roteiro, onde está a introdução do material e as explicações de como usá-lo. Nela aparece escrito que "ao percorrer a trilha, você poderá notar mudanças na paisagem, na luminosidade, na temperatura, além de reconhecer diferentes seres vivos, sons, aromas, cores, formatos e texturas"

Tá escutando, Antonia? (Maria, turno 257)

Deixa eu ver ((sussurrando)) (Antonia, 258)

Você está ouvindo que ela faz barulho? (Maria, turno 265)

Tá vendo o barulhinho d'água, agora? Tá ouvindo? (Laura, turno 266)

Tô (Antonia, 267)

É bem relaxante, não é? (Maria, turno 268)

Ah, é (Laura, turno 269) 
Quando chegam ao final do trajeto da trilha, Maria mostra para a sobrinha a nascente do Riacho do Ipiranga e procura explicar o ciclo hidrológico e à hidrogeologia da Nascente:

Deixa eu explicar um negócio pra você: Tá vendo? É aqui que nasce os rios, ó, vem desses lugarzinhos, tá vendo? Aqui é a nascentezinha. Aí a água, a chuva cai, molha aqui as plantinhas, e aí dessas plantinhas aqui, a água vai crescendo e vai para o rio. É como se fosse uma esponjinha que pega a água da chuva. É bem legal, tá vendo? (Maria, turno 342)

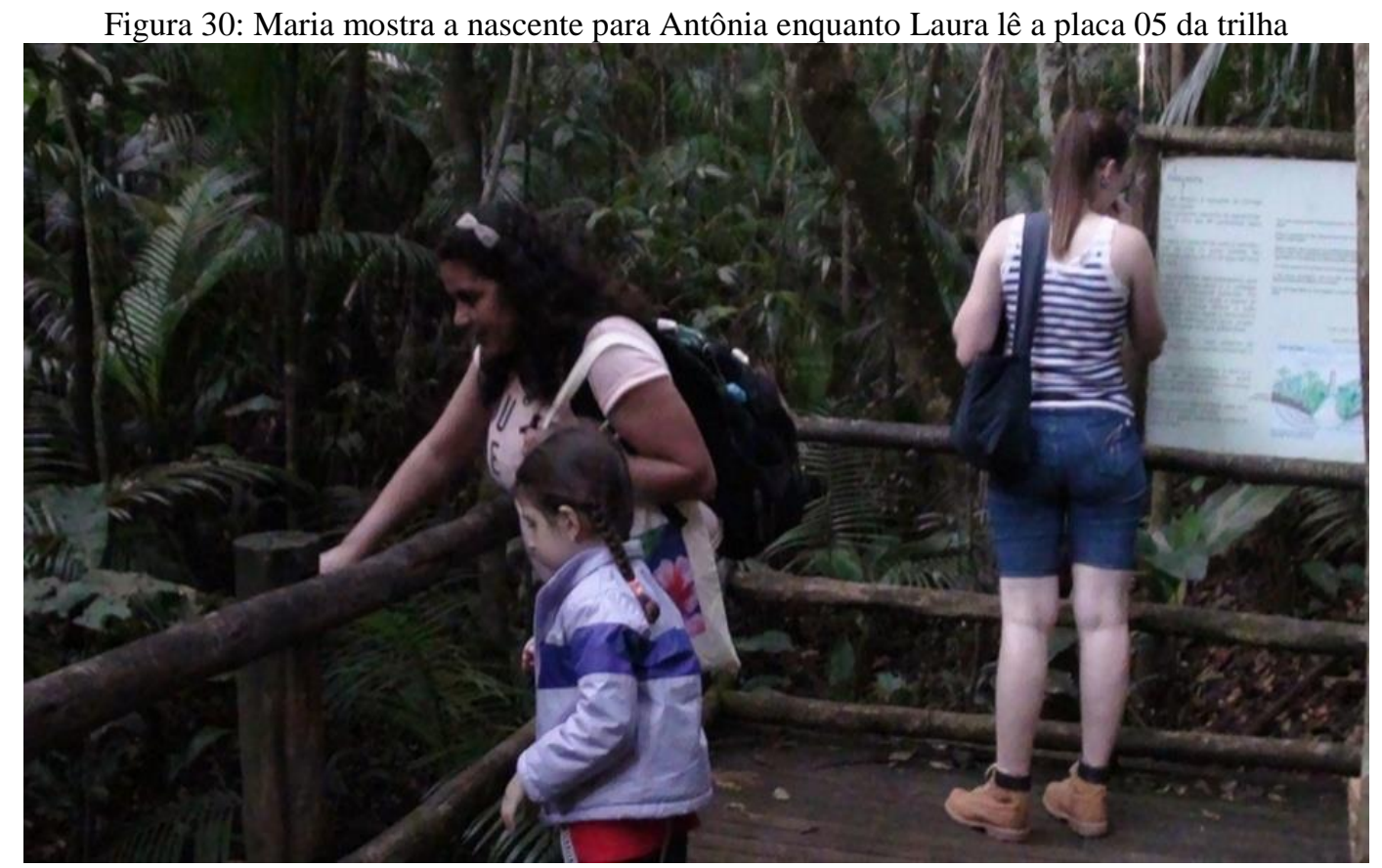

Fonte: elaboração própria

Sabemos que a água das chuvas tem diferentes caminhos neste local (SÃO PAULO (Estado)). Podemos ver na explicação de Maria evidências desses diferentes percursos: parte da água que vem das chuvas é interceptada pelas plantas, evapora e volta para a atmosfera; outra parte escoa superficialmente formando as enxurradas e, através de um córrego (neste caso, o Pirarungáua) ou rio, abandona rapidamente a bacia hidrográfica; outra parte ainda - que acreditamos estar em destaque na explicação de Maria - é aquela que se infiltra no solo, com uma parcela temporariamente retida nos espaços porosos (“é como se fosse uma esponjinha”). Há também uma parte da água que é absorvida pelas plantas ("a chuva cai, molha as plantinhas") ou evapora através da superfície do solo. Além disso, outra parte da água alimenta os lençóis freáticos ou "aquíferos artesianos livres" (“a água vai crescendo") que, dada a ausência de 
confinamento e proximidade à superfície, flui livremente. Pode acontecer da água "brotar" - formando uma nascente - que dará origem a um curso d'água ("vai para o rio").

Desse modo, as referências ao ciclo hidrológico e à hidrogeologia da Nascente na fala de Maria revela a presença do indicador científico (1), representado pelo atributo 1.a. conceitos científicos e suas definições. Considerando que "nascente" é o local onde se inicia um curso de água, Maria se reporta novamente a este atributo ao apresentar este conceito durante a entrevista, ao explicitar o que mais gostou na trilha dizendo:

\begin{abstract}
Ah, eu gostei da nascente, que é muito legal ver como é que começa, o início dos rios, geralmente a gente já vê, assim, o rio já, e ver a fonte dele, o começo dele, ainda mais para explicar para ela, é bem interessante, porque a gente, quando vai na praia ou vai num riacho assim, a gente já vê o rio lá pronto. Mas tudo tem um começo, até os rios. Então eu, particularmente, o que mais gostei foi de ver os rios e os macaquinhos, que é a distração ali, eles são bem bonitinhos (Maria)
\end{abstract}

A partir do diálogo estabelecido e por meio das falas de Maria (turno 342 e entrevista) verifica-se também o atributo $\underline{1 . d \text {. construção de conhecimento a partir da }}$ interação com o objeto/texto presente no discurso expositivo relativo ao indicador científico (1). É possível encontrar também o indicador estético/afetivo (4) com os atributos: 4.a. expressão de sentimentos a partir da interação com a exposição - notórios nos turnos 40 "que bonitinho" e 268 "é bem relaxante, não é?"; 4 .b. possibilidade de interação e de contemplação dos elementos da exposição e e $\underline{4 . c . \text { motivação do público no }}$ envolvimento com o tema exposto, quando Antônia responde positivamente ao questionamento "você gostou?", feito pela tia.

Nessa SDR verifica-se cinco das sete habilidades investigativas propostas, a saber: observação - quando as visitantes visualizam o córrego e a nascente (turnos 34, 35, 36, 258, 259); afirmação - nas vezes em que Laura e Antônia confirmam o que está sendo observado (turnos 36, 37, 261, 263, 264, 267 e 269); comparação - quando Maria relaciona a água do córrego à nascente que abastece um lago externo à trilha (turno 38), mostrando entre eles um ponto de semelhança; questionamento - nas dúvidas sobre a exposição (“daqui ele vai pra lá?”, turno 39) e nas perguntas elaboradas por Maria para envolver os demais participantes do grupo (“tá escutando, Antonia?", e "você está ouvindo que ela faz barulho?", turnos 257 e 265); explicação - percebida nas falas em que Maria interpreta e esclarece o que está sendo observado (turnos 40 [“vai, ó (...). A água sai daqui ó"], 259 [“aqui é onde riozinho nasce"] e 342); emissão de opinião - nas manifestações de juízo enunciadas por Maria (turnos 40 ["que bonitinho"] e 268 ["é bem relaxante, não é?"]) e ao dizer na entrevista que achou “muito legal ver como é que 
começa o início dos rios", elencando a nascente como seu momento preferido da visita. No caso, as habilidades de afirmação e questionamento não haviam sido previstas incialmente no roteiro.

Quadro 10 - Síntese dos Indicadores de Alfabetização Científica, Atributos e Habilidades Investigativas relacionados ao quadro 07 do roteiro

\begin{tabular}{|c|c|c|c|}
\hline Indicadores - Atributos / Habilidades & $\begin{array}{c}\text { Antes/na } \\
\text { produção do } \\
\text { roteiro }\end{array}$ & $\begin{array}{l}\text { Durante a } \\
\text { visita }\end{array}$ & $\begin{array}{l}\text { Após a } \\
\text { visita/entrevista }\end{array}$ \\
\hline \multicolumn{4}{|l|}{ Indicador Científico (1): } \\
\hline 1.a Conceitos científicos e suas definições & $\mathrm{X}$ & $\mathrm{X}$ & $\mathrm{X}$ \\
\hline $\begin{array}{l}\text { 1.d. Construção de conhecimento a partir da } \\
\text { interação com o objeto/texto presente no discurso } \\
\text { expositivo }\end{array}$ & $\mathrm{X}$ & $X$ & $X$ \\
\hline \multicolumn{4}{|l|}{ Indicador Institucional (2): } \\
\hline $\begin{array}{l}\text { 2.a. Importância das coleções mantidas pela } \\
\text { instituição. }\end{array}$ & $\mathrm{X}$ & - & - \\
\hline \multicolumn{4}{|l|}{ Indicador Social (3): } \\
\hline $\begin{array}{l}\text { 3.c. Aplicação social do conhecimento científico, } \\
\text { incluindo a conexão entre a temática expositiva e } \\
\text { o cotidiano, possibilitando tecer relações entre a } \\
\text { ciência e as questões sociais, históricas, políticas, } \\
\text { econômicas e ambientais. }\end{array}$ & $\mathrm{X}$ & - & - \\
\hline $\begin{array}{l}\text { 3.e. posicionamento do público diante dos } \\
\text { resultados da ciência }\end{array}$ & $X$ & - & \\
\hline \multicolumn{4}{|l|}{ Indicador Estético/Afetivo (4): } \\
\hline $\begin{array}{l}\text { 4.a. expressão de sentimentos a partir da interação } \\
\text { com a exposição }\end{array}$ & - & $X$ & - \\
\hline $\begin{array}{l}\text { 4.b. Possibilidade de interação e contemplação } \\
\text { dos elementos da exposição; }\end{array}$ & $\mathrm{X}$ & $\mathrm{X}$ & - \\
\hline $\begin{array}{l}\text { 4.c. Motivação do público no envolvimento com } \\
\text { o tema exposto }\end{array}$ & $\mathrm{X}$ & $\mathrm{X}$ & - \\
\hline \multicolumn{4}{|l|}{ Habilidades investigativas: } \\
\hline Observação & $\mathrm{X}$ & $\mathrm{X}$ & - \\
\hline Afirmação & - & $\mathrm{X}$ & - \\
\hline Comparação & - & $\mathrm{X}$ & - \\
\hline Explicação & $\mathrm{X}$ & $\mathrm{X}$ & - \\
\hline Questionamento & - & $X$ & - \\
\hline Emissão de opinião & $X$ & $X$ & $\mathrm{X}$ \\
\hline Conclusão & $\mathrm{X}$ & - & - \\
\hline
\end{tabular}

Fonte: elaboração própria 
VIII) Eixo temático: interação do homem com a natureza (quadro 8)

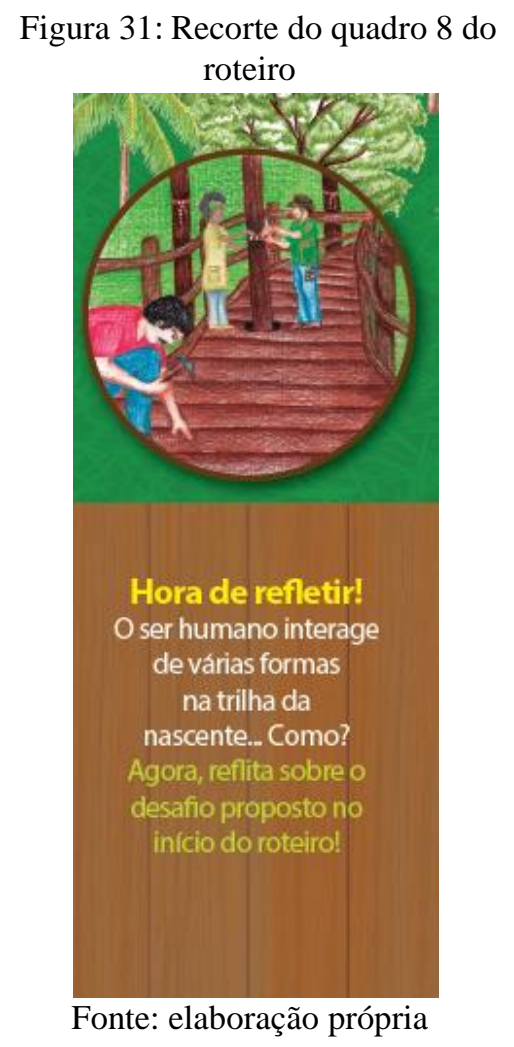

\section{VIII.1) Informações Gerais}

* Imagem: Pessoas interagindo na Trilha. Ao fundo, dois pesquisadores demarcam árvores para identificar uma amostra para estudo. À frente, homem utilizando martelo para manutenção do trajeto da trilha.

* Subtítulo: Hora de refletir!

* Texto complementar ao subtítulo: $O$ ser humano interage de várias formas na Trilha da Nascente... Como?

* Texto Principal (em destaque): Agora reflita sobre o desafio proposto no início do roteiro!

VIII.2) Indicadores, atributos de AC e habilidades investigativas usadas na produção do roteiro:

Neste quadro 8 foi proposto o atributo 1 .e. papel do pesquisador no processo de produção do conhecimento do indicador científico (1) e o atributo 2.b. missão institucional como produtora e disseminadora de conhecimento científico relativo ao indicador institucional (2), pois é intenção que se perceba a Trilha como parte da instituição Jardim Botânico e que se reconheça a sua missão para o desenvolvimento e divulgação da ciência.

Na frase $O$ ser humano interage de várias formas na Trilha da Nascente... Como?, notamos a afirmação de que o ser humano interage com a Trilha e a pergunta "Como?" não apenas convida a pensar "como" o ser humano interage mas também "quem" é este ser humano. Dessa forma, a reflexão oriunda desse questionamento teve a intenção de levar o visitante a pensar e se posicionar sobre as diversas formas de envolvimento com o ambiente e como esse pode ser afetado, de maneira benéfica ou não, favorecendo o

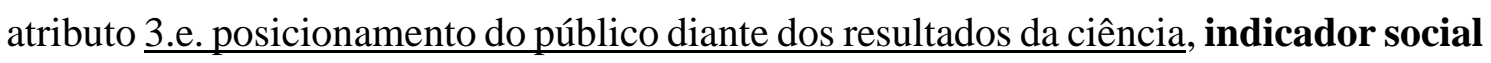
(3). 
A imagem, aliada aos diferentes níveis de texto nesse quadro favorecem o atributo 4.c. motivação do público no envolvimento com o tema exposto do indicador estético/afetivo (4).

No que se refere às habilidades investigativas, por meio da ilustração e dos textos, esse quadro procura estimular a observação do meio para que o visitante possa verificar e comparar se os elementos descritos no roteiro se fazem presentes de alguma forma naquele ambiente. A ideia desse quadro é também promover questionamentos sobre "quem" e "como" se dão as interações nesse local e, ao retomar o desafio, convidar o visitante a emitir opinião sobre os elementos da natureza e as sobre as possibilidades de contribuição para o equilíbrio desse ambiente.

\section{VIII.3) Indicadores, atributos e habilidades expressos pelos visitantes:}

Em dois momentos da visita, integrantes da família observam resíduos sólidos deixados por outras pessoas que visitaram a trilha: nos turnos de 150 a 154 e de 213 a 238. No turno 150, Maria alerta Antonia para a existência de uma garrafa de refrigerante jogada no solo e sobre a importância do destino adequado do lixo para evitar a degradação e poluição do ambiente:

[...] ó, deixa eu te falar um negócio que você não pode fazer, quando você vem na floresta, não pode fazer isso, tá vendo ali? (Maria, turno 150)

\section{Tô. (Antonia, turno 151)}

Aqui, perto das árvores tem uma garrafa "Dolly", tá vendo? Não pode jogar sujeira na natureza, senão contamina a natureza e aí os bichinhos, depois, não tem o que comer, porque sujeira suja tudo. Onde a gente joga a sujeira? (Maria, turno 152)

No lixo! (Antônia, turno 153)

Isso mesmo! (Maria, turno 154)

O assunto é retomado posteriormente entre os turnos 213 e 238 quando Maria, Laura e Antônia confabulam na tentativa de desvendar um objeto na área externa da trilha; se dão conta que se trata de um papel, mas desta vez Maria questiona Antonia por querer observar isso (turno 227):

Aquilo ali é uma pedra? Ou é um ovo? (Maria, turno 213)

Não sei. (Laura, turno 214)

Deixa eu ver (Antônia, turno 215) 
É, aquela coisa branca ali. (Maria, turno 217)

Sei lá. Parece que é pedra. (Laura, turno 218)

É um papel. Não gente, é um papel. É, num pode jogar ali. Olha tem outro papel! (Antônia, turno 219)

Será? pra mim, eu pensei que era um ovo. Tem. (Maria, 220)

Tem dois! (Antônia, turno 221)

No meio do nada tem um ovo... (Laura, turno 222)

Vem ver, vem ver, titia! É um papel, vem ver. Um papel! Vem. (Antônia, turno 225)

O que? Você quer ver o papel, minha filha? (Maria, turno 226)

Tá ali, ó. (Antônia, turno 227)

Deixa a tia ver. Não, Antonia. É uma pedra. (Maria, turno 228)

Vamo, que tem muita coisa legal pra gente ver ainda. (Maria, turno 237)

Tem. É um papel. (Antônia, 237)

Tá bom, chega, bora! Ó, vamos ver a natureza. É papel porque alguma pessoa jogou lá em baixo. Não pode maltratar a natureza; a natura demora muito tempo para desmanchar o papel, ai os bichinhos vão ficar sem o que comer. Vem, vamos dar uma olhada aqui. Não é pra olhar “os papel". Ó o rio, ó. (Maria, turno 238)

Maria encerra essa parte do diálogo relacionando a presença daquele resíduo como procedente à uma ação humana, mas ao dizer: "chega, bora! Ó, vamos ver a natureza" sugere possuir uma visão sobre a relação homem e natureza que não considera que ele [e suas interações] façam parte dela, já que veriam a 'natureza' no momento seguinte "não é pra olhar "os papel”. Ó o rio, ó".

Figura 32: Família observa a garrafa PET e interage
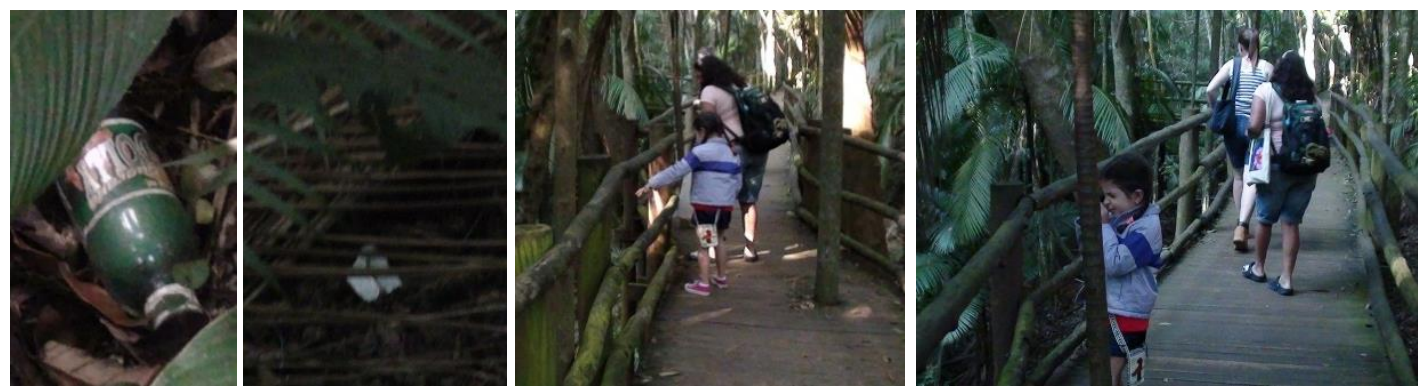

Fonte: elaboração própria 
Considerando que qualquer atividade que o homem exerça no meio ambiente provocará um impacto ambiental ${ }^{14}$, as observações realizadas nestes casos se reportam a um tipo de impacto negativo que acarreta na poluição do ambiente. Logo, as advertências nos diálogos sobre a problemática do lixo são aqui apresentadas como formas de interação do homem com a natureza.

Quando, na entrevista, foi perguntado aos visitantes quais as diversas formas que o ser humano poderia se fazer presente nessa trilha, Laura fala sobre duas formas opostas de interação no meio:

Tem o lado ruim, que eles abriram o caminho e acabou desequilibrando um pouco e aí, pelo menos, eles não cortaram todas as árvores do caminho, mas tenho certeza que uma ou outra foi tirada fora do caminho pra fazer a trilha. E tem o lado bom, que a gente pode interagir (Laura)

Laura associa a perturbação no equilíbrio deste ecossistema como parte do processo da construção da trilha. É importante dizer que essa relação temporal não está explicitada na placa 2 (Manejo) da trilha e, embora a placa 1 (Trilha da Nascente) diga que na construção "a remoção das árvores foi evitada ao máximo e as retiradas foram transplantadas para outro local da floresta", a retirada de árvores é considerada por Laura algo negativo, mas a possibilidade de visitação e interação neste local pelo público é positivo.

Os turnos 269 a 277, embora não se reportem diretamente ao roteiro, evidenciam as diferentes formas com que as visitantes interagem (ou teriam vontade de interagir), além da expressão de suas sensações, em relação ao ambiente:

Ah, é. Dá para dormir aqui (Laura, turno 269)

Tá vendo, ó? (Maria, turno 270)

Ah, não. Tá cheio de sujeira! (Antônia, turno 271)

Tem aranha aqui! (Antônia, turno 273)

((risos)) Você não entende o espírito da coisa, né? (Maria, turno 274)

Você é uma menina da cidade mesmo ((risos)). (Laura, turno 275)

Ah, Meu Deus do Céu. (+) Olha, Laura, tem que ser mais ela pro mato, pra ela ir se acostumar. Fica apavorada com as coisas pequenas, imagina

\footnotetext{
${ }^{14}$ A resolução Conama $\mathrm{N}^{\circ} 001$ de janeiro de 1986 define impacto ambiental como "qualquer alteração das propriedades físicas, químicas e biológicas do meio ambiente, causada por qualquer forma de matéria ou energia resultante das atividades humanas que, direta ou indiretamente, afetam a saúde, a segurança e o bem-estar da população; as atividades sociais e econômicas; a biota; as condições estéticas e sanitárias do meio ambiente; e a qualidade dos recursos ambientais". (BRASIL, 1986)
} 
se leva ela no zoológico ou a algum lugar desse tipo. (Maria, turno 276)

A gente foge, as duas. (Laura, turno 277)

E ainda, nos turnos a seguir, Maria revela suas impressões sobre a relação dos visitantes com espaço expositivo e mesmo entre eles:

Eu acho que o espetáculo são os seres humanos. (Maria, turno 310)

Eu queria te dizer isso, mas acho que são. A gente está passando de dia, as pessoas tão vendo lá; a gente... Sei lá, olha com uns olhos. (Maria, turno 312)

Eu tô me sentindo praticamente parte da fauna e da flora. (Maria, turno 315)

Maria comenta nesse trecho que se sente observada por outras pessoas, retomando a ideia da interação humana naquele ambiente. Isso ocorre quando Antônia pega o monóculo para observar a copa das árvores e, enquanto o faz, dois visitantes passam por elas olhando atentamente as atividades das mesmas na exposição.

A SDR referente a esse eixo temático traz diversos atributos não previstos inicialmente. O primeiro que destacamos é o $\underline{3 . c \text {. aplicação social do conhecimento }}$ científico, indicador social (3), quando as visitantes estabelecem relação entre o conteúdo "interação do homem com a natureza" do roteiro e o descarte inadequado de lixo em áreas públicas urbanas, questão de ordem social, política e ambiental. Por conseguinte, apontamos o indicador científico, com o atributo $\underline{1 . d \text {. construção de }}$ conhecimento a partir da interação com o objeto/texto presente no discurso expositivo, já que as visitantes discutem o problema do impacto ambiental. E, para tanto, há 4.b. possibilidade de interação e contemplação dos elementos da exposição, reforçada na fala “a gente pode interagir” presente na entrevista. Outros atributos também não previstos, mas perceptíveis são: 2.a importância das coleções mantidas pela instituição, indicador institucional (2), no trecho "pelo menos, eles não cortaram todas as árvores do caminho"

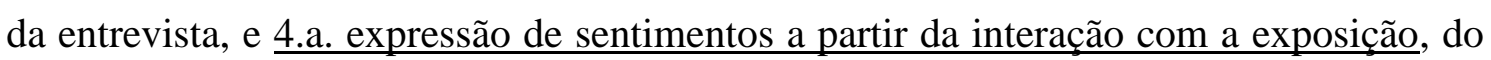
indicador estético/afetivo, entre os turnos 269 e 277, já que as visitantes falam sobre seus medos e vontades: "[Antônia] fica apavorada com as coisas pequenas" (Maria); "A gente foge” (Laura); “dá para dormir aqui (Laura).

O único indicador/atributo previsto que se manifesta na fala das visitantes nesta SDR é 4.c. motivação do público no envolvimento com o tema exposto, visto sobretudo 
nas atitudes de Antônia e nas habilidades investigativas expressas pela família ao demonstrar o ensejo de explorar os elementos observados na trilha.

Em relação às habilidades investigativas, averiguamos a presença de observação em diversos momentos das SDRs e emissão de opinião - a exemplo do turno 150 "não pode fazer isso" (Maria). Essa última habilidade também aparece na fala de Laura na entrevista quando relata as suas concepções e explica aspectos positivos e negativos da interação antrópica na exposição. Outras habilidades encontradas na visita são afirmação como no turno 151 quando Antônia corrobora com a fala anterior da tia, explicação no turno 152 e conclusão nos turnos 153 e 154.

Quadro 11 - Síntese dos Indicadores de Alfabetização Científica, Atributos e Habilidades Investigativas relacionados ao quadro 08 do roteiro

\begin{tabular}{|c|c|c|c|}
\hline Indicadores - Atributos / Habilidades & $\begin{array}{c}\text { Antes/na } \\
\text { produção do } \\
\text { roteiro }\end{array}$ & $\begin{array}{l}\text { Durante a } \\
\text { visita }\end{array}$ & $\begin{array}{l}\text { Após a } \\
\text { visita/entrevista }\end{array}$ \\
\hline \multicolumn{4}{|l|}{ Indicador Científico (1): } \\
\hline $\begin{array}{l}\text { 1.d. Construção de conhecimento a partir da } \\
\text { interação com o objeto/texto presente no } \\
\text { discurso expositivo; }\end{array}$ & - & $\mathrm{X}$ & - \\
\hline $\begin{array}{l}\text { 1.e. papel do pesquisador no processo de } \\
\text { produção do conhecimento }\end{array}$ & $\mathrm{X}$ & - & - \\
\hline \multicolumn{4}{|l|}{ Indicador Institucional (2): } \\
\hline $\begin{array}{l}\text { 2.a importância das coleções mantidas pela } \\
\text { instituição }\end{array}$ & - & - & $\mathrm{X}$ \\
\hline $\begin{array}{l}\text { 2.b. Missão institucional como produtora e } \\
\text { disseminadora de conhecimento científico. }\end{array}$ & $X$ & - & - \\
\hline \multicolumn{4}{|l|}{ Indicador Social (3) } \\
\hline $\begin{array}{l}\text { 3.c. Aplicação social do conhecimento } \\
\text { científico }\end{array}$ & - & $\mathrm{X}$ & - \\
\hline $\begin{array}{l}\text { 3.e. Posicionamento do público diante dos } \\
\text { resultados da ciência). }\end{array}$ & $\mathrm{X}$ & - & - \\
\hline \multicolumn{4}{|l|}{ Indicador Estético/Afetivo (4): } \\
\hline 4.a. Expressão de sentimentos & - & $\mathrm{X}$ & - \\
\hline $\begin{array}{l}\text { 4.b. Possibilidade de interação e contemplação } \\
\text { dos elementos da exposição }\end{array}$ & - & $\mathrm{X}$ & $\mathrm{X}$ \\
\hline $\begin{array}{l}\text { 4.c. Motivação do público no envolvimento } \\
\text { com o tema exposto }\end{array}$ & $\mathrm{X}$ & $\mathrm{X}$ & - \\
\hline \multicolumn{4}{|l|}{ Habilidades Investigativas: } \\
\hline Observação & $\mathrm{X}$ & $\mathrm{X}$ & - \\
\hline Afirmação & - & $\mathrm{X}$ & - \\
\hline Comparação & $\mathrm{X}$ & - & - \\
\hline Explicação & - & $\mathrm{X}$ & $\mathrm{X}$ \\
\hline Questionamento & $\mathrm{X}$ & - & - \\
\hline Emissão de Opinião & $\mathrm{X}$ & $\mathrm{X}$ & $\mathrm{X}$ \\
\hline Conclusão & - & $\mathrm{X}$ & - \\
\hline
\end{tabular}




\section{2.b. Discussão sobre os Resultados}

Como dito anteriormente, nossa pesquisa pretendeu investigar o processo de Alfabetização Científica de uma família a partir do uso de um roteiro calcado em indicadores de Alfabetização Científica (CERATI, 2014). Também visamos o estímulo a habilidades investigativas (ASH, 1999), durante uma visita à Trilha da Nascente do Jardim Botânico de São Paulo. A metodologia aplicada nos forneceu dados importantes para a compreensão de como o roteiro desenvolvido contribuiu para auxiliar os visitantes na percepção dos elementos da Trilha da Nascente do Riacho do Ipiranga, na perspectiva da AC.

Resgatando as perguntas norteadoras desta pesquisa, a saber: "serão as visitas roteirizadas boas estratégias para promover a AC dos visitantes nos JB 's?"; "Roteiros de visita calcados nos princípios da AC podem ser eficazes para promover este processo nos visitantes de JB's?"; "Qual seu potencial e limitações?”; e, por fim, “Como roteiros de visita elaborados a partir dos princípios da AC podem auxiliar as famílias que visitam o JB de SP a se inserir nesse processo?"; dividimos este item em cinco seções:

- Indicadores e atributos de AC e as habilidades investigativas presentes e ausentes na experiência do visitante com o roteiro

- O roteiro e o seu kit

- Interação dos membros da família

- Práticas de visita e o uso de roteiros em museus/jardins botânicos

- Aspectos metodológicos da pesquisa

Entendemos as intersecções entre os diversos objetivos propostos e a organização dos dados em categorias pré-estabelecidas - indicadores de Alfabetização Científica e Habilidades Investigativas -, se constituíram como a base para o estudo da fala dos sujeitos na interação com o roteiro durante a vista à Trilha da Nascente. Esse procedimento revelou dados de cunho qualitativo, que retomamos a seguir, para a discussão dos elementos que auxiliaram a responder às questões da pesquisa, refletindo dessa forma sobre o papel desses materiais para o desenvolvimento dos processos educativos nos museus. 
- Sobre os indicadores e atributos de AC e as habilidades investigativas presentes e ausentes

Os atributos do Indicador Estético/Afetivo foram aqueles identificados com maior frequência nos momentos do percurso e da entrevista da família estudada. O item 4.a. expressão de sentimentos foi previsto nos eixos 1, 3, 4 e 5 com verificação na visita e/ou na entrevista nos eixos 1, 4, 5. Nos eixos 7 e 8 este atributo não foi previsto, mas, mesmo assim, identificado ao longo da visita. Já o atributo $\underline{\text { 4.b. possibilidade de interação }}$ e contemplação dos elementos da exposição, foi previsto e identificado em todos os eixos. Mais uma vez este atributo não havia sido previsto no eixo 8 , mas foi identificado durante a visita e na entrevista. $O$ item $\underline{\text { 4.c. motivação do público no envolvimento com o tema }}$ exposto foi pretendido e se fez presente para todos os eixos temáticos do roteiro. Esse indicador foi especialmente valorizado no roteiro não apenas nos textos, mas também nas atividades propostas, na estrutura e nas imagens nele contidas, o que talvez explique o fato de alguns dos atributos terem aparecido na fala dos visitantes mesmo não tendo sido previstos em alguns dos eixos. Sem dúvida o conjunto formado pelo ambiente da Trilha da Nascente, as informações fornecidas pelas placas e o roteiro reforçaram a dimensão estética e afetiva da Alfabetização Científica na interação do público com a exposição.

O Indicador Científico foi o segundo mais presente nas SDRs analisadas nesta pesquisa. Os atributos $\underline{1 . a . ~ c o n c e i t o s ~ c i e n t i ́ f i c o s ~ e ~ s u a s ~ d e f i n i c ̧ o ̃ e s ~ e ~} \underline{1 . d \text {. construção de }}$ conhecimento a partir da interação com o objeto/texto presente no discurso expositivo foram propostos em 06 eixos temáticos e verificou-se que tais atributos apareceram nas falas associadas a 05 dos eixos, tanto durante a visita quanto na entrevista, indicando que o roteiro possibilitou a conexão entre os elementos destacados no roteiro e aqueles observados na Trilha na perspectiva da conceituação e da construção de conhecimentos científicos.

Ainda com relação a este indicador, os atributos $\underline{1 . b}$ resultados da pesquisa científica e 1.e. papel do pesquisador no processo de produção do conhecimento foram previstos em 02 eixos temáticos do roteiro, mas aparecem associados a apenas 01 dos eixos na fala das visitantes. Já o atributo 1.c. processo de produção de conhecimento

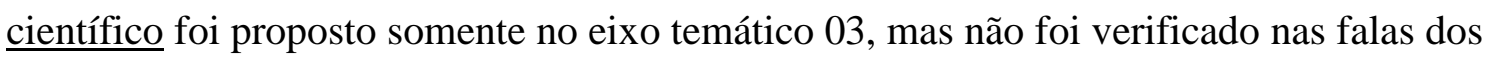
visitantes. Destaca-se que o atributo 1.f. evolução da ciência não foi proposto inicialmente em nenhum eixo do roteiro, mas foi verificado nas falas durante a visita e na entrevista, associado ao eixo 02. Tais ausências apontam algumas possíveis limitações com relação 
ao roteiro no que se refere ao Indicador Científico, já que alguns dos atributos previstos não foram identificados nos visitantes.

A respeito do Indicador Institucional, o atributo $\underline{\text { 2.a. importância das coleções }}$ mantidas pela instituição foi previsto nos eixos 1, 3 e 7, mas apenas verificado no eixo 3. Entretanto, este atributo aparece na fala das visitantes no eixo 8, onde não havia sido previsto. Por sua vez, o atributo 2.b. missão institucional como produtora e disseminadora de conhecimento científico foi previsto nos eixos 1, 2, 3 e 8, mas só apareceu no eixo 2. Já o atributo 2.e. contextualização da dimensão histórica da instituição e seu papel para o desenvolvimento científico foi previsto para o eixo 1 , mas não foi verificado nem na visita nem na entrevista. Verifica-se assim que a presença deste indicador foi menor em relação ao esperado com o uso do roteiro.

Nem todos os atributos do Indicador Interface Social propostos na ferramenta teórico-metodológica proposta por Cerati (2014) foi contemplada na elaboração do roteiro. $\mathrm{O}$ atributo 3.c. aplicação social do conhecimento científico foi previsto, mas não verificado, nos eixos 3 e 7. No entanto, na interação dos sujeitos da pesquisa com outros visitantes no eixo 8, este atributo foi identificado mesmo sem ter sido previsto para este eixo. Por outro lado, o atributo $\underline{\text { 3.e. posicionamento do público diante dos resultados da }}$ ciência foi previsto nos eixos 7 e 8 , mas não verificado em ambos. Trata-se, pois de indicador pouco explorado no roteiro e pouco presente nas falas das visitantes.

Em resumo e com base nos dados obtidos, concluímos que o roteiro associado aos demais elementos da Trilha permite o desenvolvimento dos quatro indicadores de Alfabetização Científica. Em especial, o roteiro por nós elaborado foi capaz de promover de forma satisfatória os atributos referentes aos indicadores estético-afetivo e científico, conforme previsto inicialmente. Com relação ao indicador institucional, apesar de vários atributos terem sido identificados junto aos visitantes, a presença dos mesmos ficou aquém do previsto na produção do roteiro. Por fim a presença do indicador interface social foi pouco valorizada no roteiro e, do mesmo modo, pouco identificada nas falas dos visitantes.

Quanto às habilidades investigativas, a observação foi aquela com maior presença na produção do roteiro e também a mais identificada nos dados junto ao público, em todos os eixos. A segunda habilidade investigativa mais identificada no roteiro foi a emissão de opinião, tendo sido prevista nos eixos $1,3,4,5,6,7,8$. Mesmo não tendo sido uma habilidade proposta no segundo eixo, ela foi identificada tanto na vista quanto nas entrevistas. Por outro lado, esta habilidade não apareceu no sexto eixo. A explicação é a 
habilidade que aparece em terceiro lugar e foi prevista para os eixos 1, 2, 3, 5, 6 e 7, tendo sido apenas não verificada no eixo 6. Em contrapartida, apareceu nos quarto e oitavo eixos, mesmo sem ter sido prevista. A habilidade de conclusão - prevista para os eixos 1 , 3, 6 e 7 - foi verificada na visita somente no eixo 3; contudo, vale apontar sua presença nos eixos 5 e 8 mesmo sem ter sido prevista. As habilidades de comparação e questionamento tiveram ocorrências similares, já que ambas haviam sido previstas para o oitavo eixo temático e apareceram apenas em eixos não previstos, a saber: eixos 4, 5, 6 e 7 para a comparação e 3, 4, 5 e 7 para o questionamento. Da mesma forma, habilidade afirmação, não prevista incialmente, foi identificada em 6 eixos temáticos. A identificação de habilidades investigativas pouco presentes ou ausentes do roteiro nas visitas e/ou entrevistas, sugere que elas foram subestimadas na produção deste material e que o conjunto formado pelos textos, atividades e imagens do roteiro possuem um grande potencial de promover tais habilidades em visitas a museus.

Quadro 12 - Síntese dos Indicadores de Alfabetização Científica, Atributos e Habilidades Investigativas

\begin{tabular}{|c|c|c|c|c|c|c|c|c|c|c|c|c|c|c|c|c|c|c|c|c|c|c|c|c|c|}
\hline \multirow{3}{*}{\multicolumn{2}{|c|}{$\begin{array}{c}\text { Indicador - Atributo } \\
\text { Habilidades } \\
\text { Investigativas }\end{array}$}} & \multicolumn{24}{|c|}{ Eixo Temático } \\
\hline & & \multicolumn{3}{|c|}{1} & \multicolumn{3}{|c|}{2} & \multicolumn{3}{|c|}{3} & \multicolumn{3}{|c|}{4} & \multicolumn{3}{|c|}{5} & \multicolumn{3}{|c|}{6} & \multicolumn{3}{|c|}{7} & \multicolumn{3}{|c|}{8} \\
\hline & & $\mathbf{P}$ & \begin{tabular}{l|l}
$\mathbf{V}$ & 1 \\
\end{tabular} & \multirow[t]{2}{*}{$\mathbf{E}$} & \multirow[t]{2}{*}{$\mathbf{P}$} & \begin{tabular}{|l|l}
$\mathbf{V}$ & 1 \\
\end{tabular} & \multirow[t]{2}{*}{$\mathbf{E}$} & \multirow[t]{2}{*}{$\mathbf{P}$} & \multirow[t]{2}{*}{\begin{tabular}{|l|l}
$\mathbf{V}$ & 1 \\
\end{tabular}} & \multirow[t]{2}{*}{$\mathbf{E}$} & \multirow[t]{2}{*}{$\mathbf{P}$} & \begin{tabular}{l|l}
$\mathbf{V}$ & $\mathbf{I}$ \\
\end{tabular} & \multirow[t]{2}{*}{$\mathbf{E}$} & \multirow[t]{2}{*}{$\mathbf{P}$} & \multicolumn{2}{|l|}{$\mathbf{V}$} & \multirow[t]{2}{*}{1} & V & $\mathbf{E}$ & $\mathbf{P}$ & $\mathbf{V}$ & $\mathbf{E}$ & $\mathbf{P}$ & $\mathbf{V}$ & $\mathbf{E}$ \\
\hline Indicador & Atributo & & & & & & & & & & & & & & & & & & & & & & & & \\
\hline & 1.a & - & - & - & $X$ & - & $\mathrm{X}$ & $X$ & $X$ & $\mathrm{X}$ & $\mathrm{X}$ & $\mathrm{X}$ & - & $\mathrm{X}$ & - & - & $X$ & $\mathrm{X}$ & - & $\mathrm{X}$ & $\mathrm{X}$ & $X$ & - & - & - \\
\hline & 1.b & - & - & - & $\mathrm{X}$ & $\mathrm{X}$ & $x$ & $\mathrm{X}$ & - & - & - & - & - & - & - & - & - & - & - & - & - & - & - & - & - \\
\hline & 1.c & - & - & - & - & - & & $\mathrm{X}$ & - & - & - & - & - & - & - & - & - & - & - & - & - & - & - & - & - \\
\hline Cientifico & 1.d & $\mathrm{X}$ & - & - & $\mathrm{X}$ & $\mathrm{X}$ & $x$ & $\mathrm{X}$ & $\mathrm{X}$ & $\mathrm{X}$ & $\mathrm{X}$ & $\mathrm{X}$ & - & - & $\mathrm{X}$ & $\mathrm{X}$ & $\mathrm{X}$ & $\mathrm{X}$ & $\mathrm{X}$ & $\mathrm{X}$ & $\mathrm{X}$ & $\mathrm{X}$ & - & $\mathrm{X}$ & - \\
\hline & 1.e & - & - & - & $X$ & $X$ & $\mathrm{X}$ & - & - & - & - & - & - & - & - & - & - & - & - & - & - & - & $\mathrm{X}$ & - & - \\
\hline & 1.f & - & - & - & - & $\mathrm{X}$ & $X$ & - & - & - & - & - & - & - & - & - & - & - & - & - & - & - & - & - & - \\
\hline & 2.a & $X$ & - & - & - & - & - & $X$ & $X$ & $\mathrm{X}$ & - & - & - & - & - & - & - & - & - & $\mathrm{X}$ & - & - & - & - & $\mathrm{X}$ \\
\hline & $2 . b$ & $\mathrm{X}$ & - & - & $\mathrm{X}$ & $X$ & $x$ & $X$ & - & - & - & - & - & - & - & - & - & - & - & - & - & - & $\mathrm{X}$ & - & - \\
\hline Institucional & 2.c & - & - & - & - & - & - & - & - & - & - & - & - & - & - & - & - & - & - & - & - & - & - & - & - \\
\hline & 2.d & - & - & - & - & - & - & - & - & - & - & - & - & - & - & - & - & - & - & - & - & - & - & - & - \\
\hline & 2.e & $\mathrm{X}$ & - & - & - & - & - & - & - & - & - & - & - & - & - & - & - & - & - & - & - & - & - & - & - \\
\hline & 3.a. & - & - & - & - & - & - & - & - & - & - & - & - & - & - & - & - & - & - & - & - & - & & & \\
\hline & 3.b & - & - & - & - & - & - & - & - & - & - & - & - & - & - & - & - & - & - & - & - & - & - & - & - \\
\hline $\begin{array}{l}\text { Interface } \\
\text { Social }\end{array}$ & 3.c & - & - & - & - & - & - & $X$ & & - & - & - & - & - & - & - & - & - & - & $X$ & - & - & - & $\mathrm{X}$ & - \\
\hline & 3.d & - & - & - & - & - & - & - & - & - & - & - & - & - & - & - & - & - & - & - & - & - & - & - & - \\
\hline & 3.e & - & - & - & - & - & - & - & - & - & - & - & - & - & - & - & - & - & - & $X$ & & - & $\mathrm{X}$ & - & - \\
\hline & 4.a & $X$ & & $X$ & - & - & - & $\mathrm{X}$ & - & - & $\mathrm{X}$ & $X$ & - & $\mathrm{X}$ & $X$ & $X$ & - & - & - & - & $\mathrm{X}$ & - & - & $\mathrm{X}$ & - \\
\hline $\begin{array}{l}\text { Estético/ } \\
\text { Afetivo }\end{array}$ & 4.b & $\mathrm{X}$ & $X$ & & $\mathrm{X}$ & $X$ & - & $\mathrm{X}$ & $X$ & $\mathrm{X}$ & $\mathrm{X}$ & $\mathrm{X}$ & - & $\mathrm{X}$ & $X$ & $X$ & $X$ & $X$ & - & $X$ & $\mathrm{X}$ & - & & $\mathrm{X}$ & $X$ \\
\hline & 4.c & $X$ & $X$ & $X$ & $X$ & - & $X$ & $X$ & $X$ & $\mathrm{X}$ & $\mathrm{X}$ & $\mathrm{X}$ & $\mathrm{X}$ & $\mathrm{X}$ & $X$ & $X$ & $X$ & $X$ & $X$ & $X$ & $X$ & - & $\mathrm{X}$ & $\mathrm{X}$ & - \\
\hline
\end{tabular}

(Continua) 


\begin{tabular}{|c|c|c|c|c|c|c|c|c|c|c|c|c|c|c|c|c|c|c|c|c|c|c|c|c|}
\hline \multirow{3}{*}{$\begin{array}{l}\text { Habilidades } \\
\text { Investigativas }\end{array}$} & \multicolumn{24}{|c|}{ Eixo Temático } \\
\hline & \multicolumn{3}{|c|}{1} & \multicolumn{3}{|c|}{2} & \multicolumn{3}{|c|}{3} & \multicolumn{3}{|c|}{4} & \multicolumn{3}{|c|}{5} & \multicolumn{3}{|c|}{6} & \multicolumn{3}{|c|}{7} & \multicolumn{3}{|c|}{8} \\
\hline & $\mathbf{P}$ & $\mathbf{V}$ & $\mathbf{E}$ & $\mathbf{P}$ & $\mathbf{V}$ & $\mathbf{E}$ & $\mathbf{P}$ & $\mathbf{V}$ & $\mathbf{E}$ & $\mathbf{P}$ & $\mathbf{V}$ & $\mathbf{E}$ & $\mathbf{P}$ & $\mathbf{V}$ & $\mathbf{E}$ & $\mathbf{P}$ & $\mathbf{V}$ & $\mathbf{E}$ & $\mathbf{P}$ & V & $\mathbf{E}$ & $\mathbf{P}$ & $\mathbf{V}$ & $\mathbf{E}$ \\
\hline Observação & $\mathrm{X}$ & $\mathrm{X}$ & & $\mathrm{X}$ & $\mathrm{X}$ & - & $\mathrm{X}$ & $\mathrm{X}$ & $\mathrm{X}$ & $\mathrm{X}$ & $\mathrm{X}$ & & $\mathrm{X}$ & $\mathrm{X}$ & & $\mathrm{X}$ & $\mathrm{X}$ & $\mathrm{X}$ & $\mathrm{X}$ & $\mathrm{X}$ & & $\mathrm{X}$ & $X$ & \\
\hline Afirmação & & $\mathrm{X}$ & & & $\mathrm{X}$ & & & $\mathrm{X}$ & & & $\mathrm{X}$ & & & & & & & & & $\mathrm{X}$ & & & $\mathrm{X}$ & \\
\hline Comparação & & & & & & & & & & & $\mathrm{X}$ & & & $\mathrm{X}$ & & & X & $\mathrm{X}$ & & $\mathrm{X}$ & & $\mathrm{X}$ & & \\
\hline Explicação & $\mathrm{X}$ & & $X$ & $\mathrm{X}$ & $X$ & $\mathrm{X}$ & $X$ & $\mathrm{X}$ & & & $\mathrm{X}$ & & $X$ & $\mathrm{X}$ & $\mathrm{X}$ & $\mathrm{X}$ & & & $\mathrm{X}$ & $\mathrm{X}$ & & & $\mathrm{X}$ & $\mathrm{X}$ \\
\hline Questionamentos & & & & & & & & $\mathrm{X}$ & & & $\mathrm{X}$ & & & $\mathrm{X}$ & & & & & & $X$ & & $\mathrm{X}$ & & \\
\hline Emissão de opinião & $\mathrm{X}$ & $\mathrm{X}$ & $\mathrm{X}$ & & $\mathrm{X}$ & $\mathrm{X}$ & $\mathrm{X}$ & $\mathrm{X}$ & $\mathrm{X}$ & $\mathrm{X}$ & $\mathrm{X}$ & $\mathrm{X}$ & $\mathrm{X}$ & $\mathrm{X}$ & $\mathrm{X}$ & $\mathrm{X}$ & & & $\mathrm{X}$ & $\mathrm{X}$ & $\mathrm{X}$ & $\mathrm{X}$ & $\mathrm{X}$ & $\mathrm{X}$ \\
\hline Conclusão & $\mathrm{X}$ & & & & & & $\mathrm{X}$ & $X$ & & & & & & $\mathrm{X}$ & & $X$ & & & $\mathrm{X}$ & & & & $\mathrm{X}$ & \\
\hline
\end{tabular}

\begin{tabular}{|c|l|}
\hline \multicolumn{2}{|l|}{ Legenda explicativa: } \\
\hline $\mathbf{P}$ & Previsto \\
\hline $\mathbf{V}$ & Visita \\
\hline $\mathbf{E}$ & Entrevista \\
\hline & $\begin{array}{l}\text { Atributo ou habilidade investigativa previsto no roteiro e observado na fala dos visitantes } \\
\text { durante a visita e/ou na entrevista }\end{array}$ \\
\hline & $\begin{array}{l}\text { Atributo ou habilidade investigativa previsto no roteiro, mas não observado na fala dos } \\
\text { visitantes durante a visita e/ou na entrevista }\end{array}$ \\
\hline & $\begin{array}{l}\text { Atributo ou habilidade investigativa não previsto no roteiro e observado na fala dos visitantes } \\
\text { durante a visita e/ou na entrevista }\end{array}$ \\
\hline
\end{tabular}

É imperativo esclarecer que estes quadros se propõem a sintetizar e comparar as informações sobre a relação entre os indicadores, atributos e habilidades - previstos ou não na formulação do roteiro - com as observadas nas falas dos visitantes, seja na visita ou na entrevista.

A partir da análise destes resultados é possível verificar as potencialidades e os limites do roteiro produzido neste trabalho de pesquisa. As visitantes, motivadas pela observação dos elementos da Trilha e munidas das informações contidas no roteiro, foram capazes de relacionar ideias e conceitos científicos, fornecer explicações, fazer comparações, afirmações e conclusões. A presença de tais habilidades na fala dos integrantes da família analisada fornece indícios de que a experiência de visita à Trilha apoiada pelo roteiro promove o processo de construção do conhecimento.

Durante a visita foi possível perceber que tanto as placas existentes na Trilha quanto o roteiro, funcionaram como mediadores que instigaram o processo investigativo ao longo da experiência. Nesse sentido, podemos constatar que a obtenção de informações e a orientação do olhar foram elementos fundamentais para o estímulo a várias habilidades e também para a manutenção da própria curiosidade das visitantes. 
Percebeu-se nos dados que a habilidade de observação remetia constantemente aos conhecimentos prévios das visitantes. Por isso, o diálogo entre as visitantes, a partir do que conheciam e observavam, e a obtenção de informações existentes no roteiro e nas placas, foram fundamentais para a identificação de diversas outras habilidades, tais como as explicações, afirmações, os questionamentos e a emissão de opiniões.

Os dados analisados revelaram ainda a forte presença de expressões de sentimento e afeto para com a natureza (atributo 4.b), que para além das previstas inicialmente no roteiro nos quadros 1 e 4, apareceram também nos quadros 5, 7 e 8. A grande motivação das visitantes foi expressa inúmeras vezes durante a contemplação e a interação com ambiente, realizada de maneira afetuosa. Novamente, verificamos que o roteiro e as placas realizaram a mediação e conduziram o olhar, chamando-lhes atenção, como no caso do som da nascente do Córrego Pirarungáua, e promovendo a compreensão dos visitantes sobre noções científicas presentes.

Importante dizer que este material educativo foi inspirado no trabalho de Cerati (2014) e tinha por intenção reforçar alguns aspectos no processo de Alfabetização Científica que já haviam sido manifestados e/ou estimular aspectos pouco aparentes ou ausentes nas falas das famílias que visitaram a Trilha da Nascente.

A partir das observações de Cerati (2014), identificamos aspectos semelhantes, mas também outros distintos na visita entre famílias que realizam a visita à Trilha da Nascente do Riacho do Ipiranga com e sem o uso do roteiro. Nos próximos parágrafos apresentaremos possibilidades de aproximação com o trabalho da autora, intencionando ampliar o campo de investigação da visita conduzida nesta exposição do Jardim Botânico.

A metodologia estabelecida no trabalho de Cerati (2014) revela que, nas 14 Sequências de Segmentos de Diálogos analisados nas 03 famílias estudadas, a que mais se sobressaiu foi o indicador científico, seguido do indicador estético/afetivo, depois o indicador social e, por último, o institucional, conforme ilustra o gráfico por ela apresentado na página 182 : 
Figura 33: Presença de indicadores de AC identificadas nas SDRs

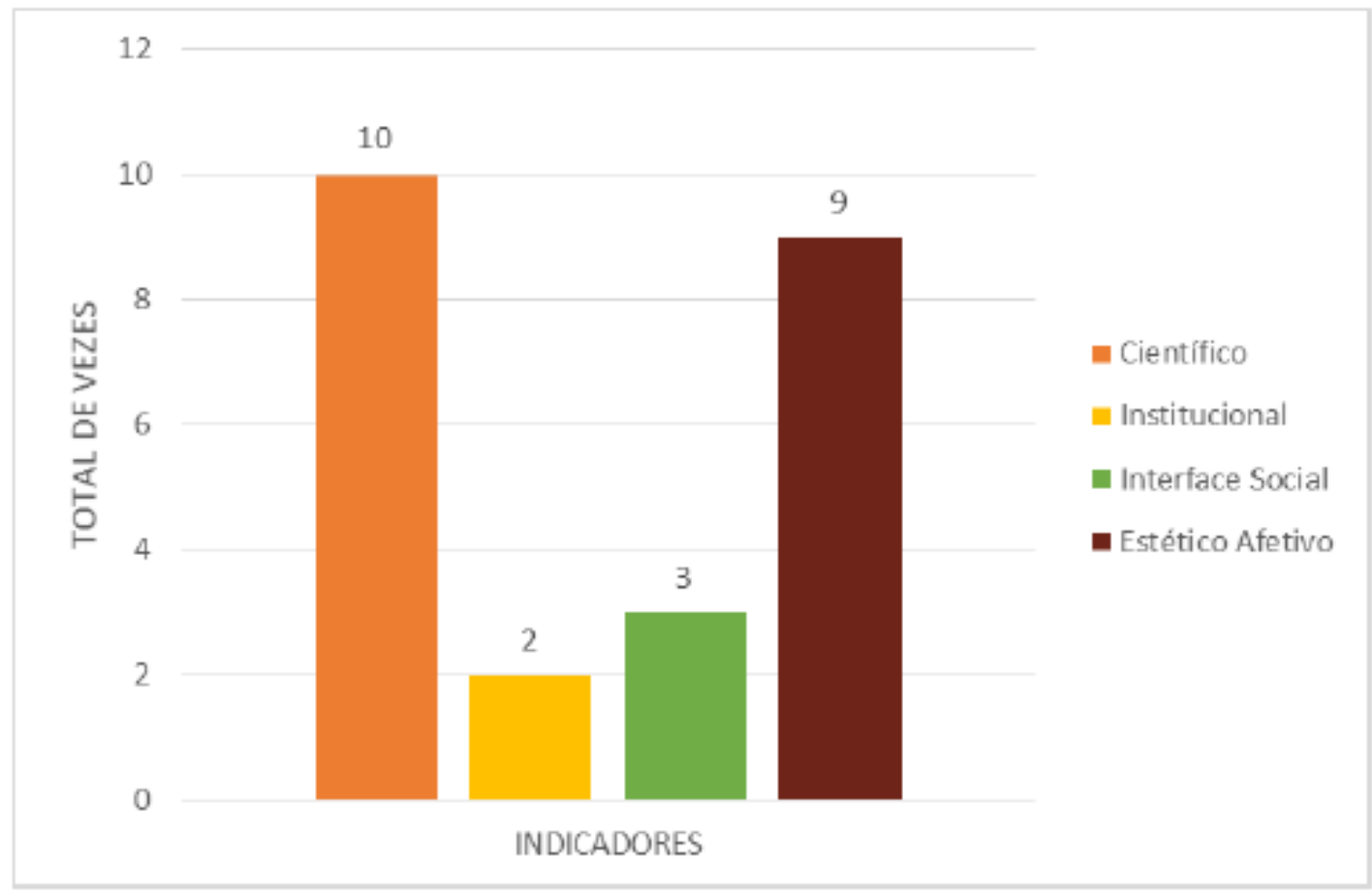

Fonte: Cerati (2014)

Nesta pesquisa, por outro lado, as Sequências dos Segmentos de Diálogos Representativos são formadas a partir dos oito eixos temáticos do roteiro. Além disso, as perguntas-guia da entrevista também estimularam os indicadores de Alfabetização Científica, fato este que permitiu a comparação entre os indicadores previstos (ou não) por eixo e que se manifestaram (ou não) na fala dos visitantes, seja durante a visita ou na entrevista. Na família participante, o indicador estético/afetivo foi o mais evidente; na sequência ficou o indicador científico, depois o indicador institucional e o indicador interface social.

O gráfico abaixo foi produzido para registrar a somatória de vezes em que cada indicador de $\mathrm{AC}$ foi identificado na fala dos visitantes durante a visita e/ou na entrevista, de acordo com os eixos temáticos do roteiro Lembrando que um indicador pode estar presente em mais de um eixo. 
Figura 34: Presença de indicadores de AC identificadas nos eixos temáticos

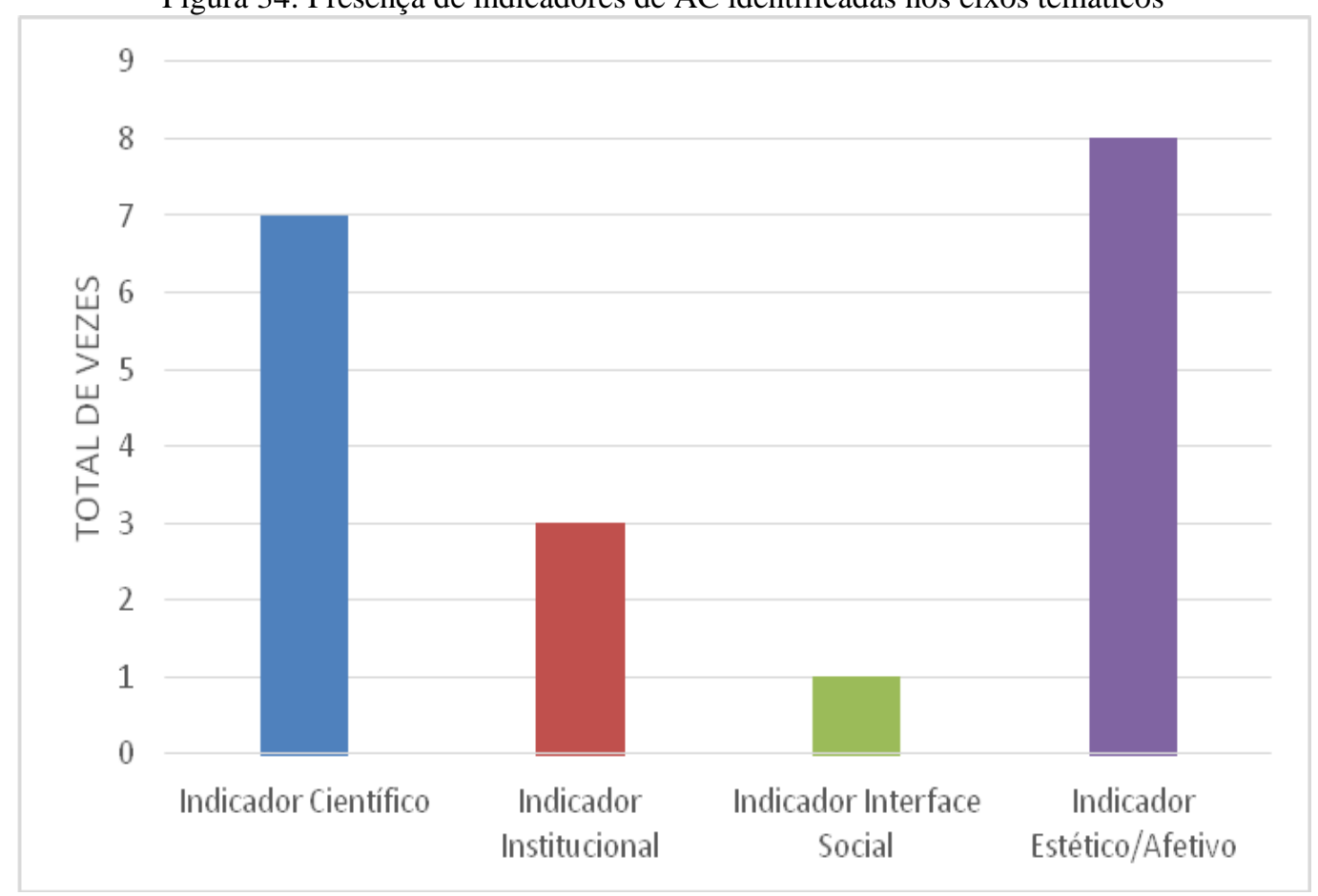

Fonte: elaboração própria

Mesmo considerando os limites desta análise sobre a quantificação das SDRs na mesma perspectiva que Cerati (2014) - já que os objetivos, o recorte das SDRs e o número de famílias que compõem o espectro das pesquisas são distintos -, em uma tentativa de aproximação e confronto entre os dados, percebe-se que o roteiro continua reforçando os indicadores científico e estético/afetivo.

Consideramos, a partir dos dados, que o roteiro possui o potencial de subsidiar a visita de famílias a exposições promovendo o processo de Alfabetização Científica. A mediação realizada por este material potencializa este processo, estimulando especialmente dimensões afetivas, estéticas e científicas, além de promovendo habilidades investigativas relevantes na relação entre o público e os elementos expositivos. Os limites encontrados no uso do roteiro com relação às dimensões institucionais e de interface social do processo de Alfabetização Científica deverão ser equacionados no futuro uso deste material com o público, seja por meio de sua revisão e aprimoramento, seja introduzindo outras estratégias de mediação que possam estimular essas dimensões. 


\section{- Sobre o roteiro e o seu kit}

Neste trabalho, foi intenção analisar os limites e potencialidades do uso de um roteiro por uma família durante uma visita à Trilha da Nascente, elaborado com a finalidade de promover o processo de Alfabetização Científica. Para dar conta deste objetivo, o roteiro foi elaborado com apoio de especialistas na área de ilustração e edição, além de passar por várias etapas de validação entre especialistas e público.

O roteiro desenvolvido encontra-se dentro da proposta de materiais didáticoculturais, elaborada por Campos (2009), quando afirma que tais materiais possuem:

caráter instrutivo ou educativo voltados diretamente para o público visitante e também aqueles que expressam manifestações intelectuais ou artísticas, estando incluso entre esses os de divulgação científica, caderno de atividades para e professores, material institucional que divulga as ações dos museus e seu acervo (CAMPOS, 2009, p.5).

Um aspecto de destaque do roteiro foram as ilustrações naturalísticas usadas para representar a Trilha, produzidas por bióloga ilustradora. Orientada por nós, esta profissional pretendeu imprimir ao roteiro o caráter de rigor e objetividade científica, utilizando formas de representação dos organismos que os aproximava do real. Como pode ser percebido nos dados obtidos sobre o uso do roteiro pela família, as imagens existentes nesse material favoreceu a comparação com os elementos da Trilha e orientou o olhar das visitantes para os objetos naturais existentes no ambiente. Também estimulou a leitura de placas e a busca por informações sobre os objetos e até mesmo sobre dúvidas surgidas na visita. Esses elementos estavam representados no roteiro, por exemplo por meio da imagem da trilha suspensa, do bugio, dos liquens, dos pesquisadores estudando e dos funcionários realizando a manutenção da trilha.

O roteiro produzido era, na verdade, parte de um kit entregue à família composto, além do próprio roteiro, por uma bolsa que continha um suporte de acrílico para apoiar o roteiro, um conjunto de lápis-de-cor, um monóculo e uma lupa. Esses materiais não estavam incialmente previstos na pesquisa. No entanto, durante o mestrado e a partir de uma bolsa Santander obtida pela pesquisadora para estagiar durante um mês no Museu de Ciência de Lisboa, em Portugal, houve a oportunidade de realizar visitas técnicas e conhecer diversas instituições museais, entre elas vários jardins botânicos portugueses. Nestas visitas, chamou atenção a qualidade da produção de materiais desenvolvidos pelo núcleo educacional do Jardim Botânico de Coimbra, que acabou servindo de inspiração 
para o desenvolvimento do roteiro deste trabalho, e, por esta razão, resolvemos incluir objetos de apoio ao roteiro impresso.

O uso do monóculo e da lupa associado ao roteiro foram previstos para favorecer alguns dos indicadores da Alfabetização Científica, em especial os científicos e estéticos/afetivos, e algumas das habilidades investigativas, como a observação e a comparação, uma vez que se trata de instrumentos concretos pertencentes ao universo da ciência. A partir dos dados obtidos verifica-se que estes objetos potencializaram o uso do roteiro e apoiaram a mediação entre público, roteiro e os elementos expositivos. Os instrumentos, associados ao roteiro e as placas, contribuíram para a imersão dos visitantes e reforçaram as habilidades investigativas intencionadas. Neste sentido, acreditamos que o uso desses instrumentos de apoio associado a roteiros impressos tem um efeito importante para a promoção da $\mathrm{AC}$ dos visitantes nos museus.

\section{- Sobre a interação dos membros da família}

A fonte de dados desta investigação foram os diálogos da família analisada. Optamos por analisar o conjunto das conversas de forma não individualizada, mas sim a partir da perspectiva das trocas entre os sujeitos e das intermediações mútuas, as quais podem ser constatadas no intercâmbio de informações, nas propostas de perguntas e problemas e nas tentativas coletivas de levantar hipóteses para resolvê-las. Por este olhar, devemos entender que a compreensão do público sobre Trilha se dá a partir de participações diferenciadas, mas complementares.

Para a pesquisa foram coletados dados de três famílias. Para a exposição de nossas reflexões, escolhemos a primeira família abordada. Esta família visitou a exposição no dia 28/07/2015 e é formada por: mãe (Laura), funcionária pública municipal, 25 anos; filha (Antonia), de 04 anos, que cursa o Ensino Infantil; e a cunhada/tia (Maria, irmã do esposo de Laura), trabalha no setor administrativo de uma empresa de call center, estuda design gráfico e possui 40 anos. Esta família afirmou que nunca havia visitado a Trilha da Nascente do Riacho do Ipiranga. Apenas Laura foi ao Jardim Botânico há 12 anos. As atividades costumeiras de lazer da família hoje ocorrem principalmente em locais fechados, sobretudo consistem em ir ao shopping e ao cinema. Laura e Maria demonstraram predisposição a conhecer espaços de educação não formal nas férias e

revelaram que Antonia demonstra interesse nesse tipo de atividade. É a partir do prisma 
de um conjunto de indivíduos com relações familiares com pouca ou nenhuma experiência museológica que nossas análises, reflexões e considerações estão sendo feitas.

Durante a análise dos dados, pudemos observar como claramente Maria assumiu uma posição de liderança no grupo, a qual pode ser percebida pela retenção do roteiro sob sua mão na maior parte do tempo. Sua postura curiosa instigou sua cunhada Laura e sua sobrinha Antônia a observar os diversos pontos da trilha, e constantemente trazendo questões de cunho explicativo. Por sua vez, Laura teve uma postura cautelosa com relação às informações obtidas ao longo da visita, contrapondo-as de forma criteriosa e problematizando certas observações e afirmações. O comportamento diferenciado das duas adultas dava o contexto de visita para a pequena Antônia, cujo encanto pela natureza era estimulado pelas pela mãe e pela tia, resultando em uma experiência única de troca entre elas e de aproximação da ciência por meio a Trilha e mediada pelo roteiro e seu kit.

Nossa abordagem teórica procurou compreender a construção de conhecimento em contextos de educação não formal, levando em conta a relação de parentesco familiar entre os indivíduos de nossa observação. De acordo com a perspectiva adotada por Bizerra $(2009$, p.51) em sua leitura da aprendizagem familiar, "os pais podem descrever evidências, dar direcionamentos ou fazer explanações que possibilitam uma maior compreensão das atividades pelos filhos". Da mesma forma, quando as crianças interagem com uma exposição em companhia de seus pais, observa-se uma exploração de evidências de maior intensidade, mais ampla e mais focada.

De acordo com Dierking, Ellenbogen e Falk (2004), há um conjunto de pressupostos disciplinares compartilhados entre os pesquisadores preocupados em estudar as visitas familiares a museus. Nesse sentido, tomam-se as famílias como agentes participativos e complementares das exposições. Também afirmam que nas visitas em família há conversas, troca de vivências, de memórias que constroem uma experiência ampla de aprendizagem ao compartilhar um conjunto de valores, referências, vocabulários, compreensões e pressupostos.

Percebemos, nesta investigação, o quão rico foram os diálogos das três visitantes ao longo do percurso, o qual surgiu da interação delas entre si e entre o conjunto de elementos que formam a Trilha da Nascente, mediado pelo roteiro e seu kit, promovendo a aprendizagem ao compartilhar um conjunto de valores, referências, vocabulários e compreensões. 
- Sobre as práticas de visita e o uso de roteiros em Museus/Jardins Botânicos

Apesar do nome "Trilha" apontar para a ideia de "andar em trilho", ou seja, um caminho linear entre um ponto e outro, não foi exatamente isto que evidenciamos no uso do roteiro durante a visita da família analisada. Percebeu-se que a interação com o espaço designado como Trilha da Nascente, não se deu de forma linear, isto é, os visitantes não percorreram ou falaram sobre os elementos da exposição de forma linear, ou de uma só vez em cada ponto o momento do percurso. Durante a visita, os temas, objetos e informações foram sendo retomadas em diversos locais e, muitas vezes, questões eram novamente abordadas instigadas por novas leituras realizadas. Da mesma forma, o roteiro não foi utilizado de maneira linear. A apropriação deste material pelas visitantes se deu em função dos pontos de atenção e informações elencadas por elas como relevantes e que vão sendo obtidas, ao mesmo tempo, em que apoia e aprofunda ideias e interesses surgidos a partir das experiências vividas. Assim sendo, a experiência de uso do roteiro pela família estudada não pode ser normatizada ou transformada em um processo de apropriação de conhecimentos "em etapas", ou mesmo "escolarizado". Esta perspectiva não é desejável, nem possível, pois arrisca pôr em cheque a "experiência museal", marcada pelo uso livre do espaço e do tempo pelo visitante (MARANDINO, 2005a).

Observamos, por outro lado, no uso do roteiro e do kit, limitações que podem, muitas vezes, se tornar um desafio para a visita. $\mathrm{O}$ roteiro acaba sendo mais um aspecto para o visitante ter que lidar ao longo da Trilha e, neste sentido, se torna um elemento que “distrai". Este problema se agrava e se torna ainda mais desafiante quando o uso do material do kit é coletivo, seja pela limitação da quantidade disponível para cada integrante do grupo, ou por dificuldades em sua manipulação.

De certo modo, o fato do roteiro não trazer textos que tivessem apenas um caráter informacional ou não se apresentar como um guia que trouxesse os elementos daquele espaço de maneira sequencial promoveu estranhamentos, já que em diversos momentos esperava-se encontrar respostas ao que se observa no ambiente no roteiro; isto a nosso ver gerou reflexões sobre o que a família esperava e nos trouxe elementos para perceber não só as potencialidades, mas também os limites de se desenvolver um material educativo para espaços de educação não formal. 


\section{- Sobre os aspectos metodológicos da pesquisa}

O processo de produção do roteiro iniciou-se com o levantamento de informações sobre o local de Trilha em sites, trabalhos de pesquisas e outras fontes. Esse levantamento orientou quatro visitas para observação e coleta de informações sobre elementos e temas existentes no espaço expositivo da Trilha passíveis de serem trabalhados no futuro roteiro. Prosseguimos a identificar os elementos que pudessem evidenciar os indicadores de AC, estabelecendo critérios específicos para a coleta e organização dos dados obtidos, a saber: uma divisão em três trechos; a referência espacial para localização dos elementos em destaque (objetos da exposição que foram utilizados como base para assuntos do roteiro); as características ambientais na qual determinado objeto estava inserido; as temáticas possíveis em que o referido elemento poderia estar inserido; as interações, ações previstas para uma atividade no roteiro. Também tomamos como fundamento os Indicadores de Alfabetização Científica, os Indicadores Institucionais, Indicadores Sociais, Indicadores Estético-Afetivos e as Habilidades Investigativas.

O conteúdo do roteiro pode ser dividido entre a Capa; a Contracapa com a apresentação da trilha, a descrição do material, dicas de como utilizá-lo e desafios propostos com a intencionalidade de "enlaçar" as atividades sugeridas no interior do roteiro em um tema comum; a área interna do roteiro, destinada a apresentar a Trilha da Nascente por meio de atividades a serem realizadas pelos visitantes e que são pautadas no estímulo a habilidades investigativas (ASH, 1999) e nos indicadores de Alfabetização Científica (CERATI, 2014); o verso, que apresenta as informações pertinentes ao Projeto no qual o roteiro está inserido e dados sobre as fontes de apoio e financiamento do mesmo, além da autoria; e finalmente, a aba direita da janela fechada, com campos em branco onde o visitante é estimulado a registrar a experiência através de um desenho. Além do roteiro, um conjunto de instrumentos de apoio - composto por lápis-de-cor, um monóculo e uma lupa - foi entregue aos visitantes dentro de uma bolsa com alça para ser utilizada durante a visita.

A primeira versão ilustrada do roteiro intencionou selecionar e adequar os contextos textuais, elaborando sobre o layout, mas sem rigor conceitual com o uso das imagens. As versões posteriores pretenderam representar a Trilha com ilustrações naturalistas e rigor científico, além de promover um caráter lúdico. As versões preliminar e final foram apoiadas financeiramente pelo Instituto Nacional de Ciência e Tecnologia 
em Toxinas/INCTTOX/CNPq ${ }^{15}$, e o material gráfico foi ilustrado por uma bióloga profissional e um designer gráfico. A validação do roteiro foi feita através de grupos distintos.

É necessário deixar claro que sabemos e assumimos que o roteiro possui uma estreita articulação com a exposição, não só por que ele foi feito para ela, mas por que as tarefas nele propostas remetem aos elementos da própria, desde as placas aos objetos. Nesse sentido, quando aferimos que uma habilidade como observação ou explicação deveria aparecer, há uma inter-relação entre roteiro e exposição que é fundamental na compreensão da análise.

A observação empírica foi conduzida com quatro famílias, entretanto escolhemos uma delas, a qual melhor expressava, em diálogos representativos, os aspectos da visita que poderiam ser mais significantemente analisados e trabalhados. Diante de uma limitação do tempo e escopo da pesquisa, optamos por nos concentrar na aplicação e análise da metodologia proposta e verificação dos dados obtidos. Nesse sentido, é fundamental apontar que o material ainda pode ser utilizado para outras produções bibliográficas e será disponibilizado para o GEENF - Grupo de Estudo de Pesquisa em Educação Não Formal e Divulgação da Ciência - núcleo dentro da Faculdade de Educação da USP, do qual fazemos parte.

O uso do software NVIVO apareceu como possibilidade para o cruzamento de dados das análises e parte dos dados foram inseridos nele. Entretanto optamos, por uma questão de recorte da pesquisa, direcionar estes esforços para um outro trabalho futuro. Mas é importante ressaltar que esta ferramenta oferece potencialidades na organização e análise de dados.

Após a visita, a realização da entrevista foi fundamental para esclarecer questões e desenvolver pressupostos obtidos durante o percurso, bem como avaliar a recepção. A entrevista de pesquisa mediou a relação entre o entrevistador/pesquisador e os entrevistados/visitantes, estimulando a retomada de aspectos que eventualmente não foram declarados oralmente no percurso. Assim, a entrevista assumiu um importante papel na triangulação da pesquisa quantitativa, em um movimento de confirmação e questionamento dos dados encontrados na visita, contrapondo falas e experiências em um

15 O INCTTOX (2009-2014), financiado pelo CNPq e FAPESP, baseia-se em estudos sobre toxinas, visando consolidar e ampliar grupos de competências científica/docente reconhecidas, abrangendo o imprescindível comprometimento socioeducativo, contemplar a inovação, o desenvolvimento de produtos e processos. Para tal possui várias ações em comunicação em ciências, por meio do subprograma "Ações em Saúde - Núcleo de Difusão", com o papel de realizar a educação e difusão de conhecimentos. 
momento posterior, verificando se as impressões realmente se reafirmam, ou então se foram ocultadas, ou ainda, reavaliadas. 


\section{CONSIDERAÇÕES FINAIS}

Nossos principais objetivos nesta pesquisa foram o desenvolvimento, produção, aplicação e análise de um roteiro educativo feito para a "Trilha da Nascente do Riacho do Ipiranga”, mantida pelo Jardim Botânico, na perspectiva da Alfabetização Científica. Para tal realizou-se a coleta de dados junto a famílias em sua interação com o material e finalmente, analisou-se os dados obtidos dentro do quadro conceitual da Alfabetização Científica (CERATI, 2014) e das Habilidades Investigativas (ASH, 1999).

Devemos nos posicionar afirmando que os roteiros educativos podem ajudar na orientação de aspectos específicos em uma exposição, pois possuem um caráter intencional de dirigir ações e o olhar do público. Sua potencialidade, portanto, se encontra no apoio formativo que os especialistas podem oferecer aos visitantes, sem conduzi-los de forma "escolarizada". Por isso, é importante ressaltar que esta espécie de material pode também inibir a liberdade de fruição da visita, e que, portanto, sua utilização deve ser uma decisão dos educadores .

Os roteiros educativos são parte importante da educação em museus, podendo ser utilizados como instrumentos de empoderamento do educador em museus (MARANDINO et al., 2016). Portanto, sugerimos a realização de um maior número de pesquisas e que os educadores de museus continuem a desenvolver e avaliar seus roteiros, sobretudo por que ainda há poucos trabalhos que discutam o desenvolvimento e produção de material de qualidade.

Ressaltamos que o roteiro pode reforçar, conduzir e qualificar os elementos presentes em uma visita, já que promove o acesso direcionado dos visitantes às informações. Compreendemos, portanto, que o uso de roteiros em museus pode contribuir na formulação das práticas educativas pelos educadores, fomentando nos visitantes uma percepção crítica e consciente dos elementos expositivos e promovendo assim o processo de Alfabetização Científica. 


\section{REFERÊNCIAS BIBLIOGRÁFICAS}

ALLEN, S. Looking for learning in visitor talk: a methodological exploration. In: LEINHARDT, G.; CROWLEY, K.; KNUTSON, K. (orgs.) Learning conversations in museums. Mahwah, NJ: Lawrence Erlbaum Associates, 2002. p. 259-302.

ALMEIDA, Adriana Mortara. Desafios da relação Museu-Escola. Comunicação \& Educação, São Paulo, n. 10, p.50-56, set-dez. 1997.

ASH, D. Dialogic Inquiry in Life Science Conversations of Family Groups in a Museum. Journal of Research in Science Teaching, v. 40, n. 2, p. 138-162, 2003.

.The process skills of inquiry. Foundations: Inquiry in the $\mathbf{K}-\mathbf{5}$ classroom, v.

2, p. 51-62. Washington, DC: National Science Foundation, 1999. Disponível em: http://www.nsf.gov/pubs/2000/nsf99148/pdf/nsf99148.pdf Acesso: dez. 2013.

ATKINS, L.J.; Velez, L.; GOUDY, D.; DUNBAR, K. The Unintended Effects of Interactive Objects and Labels in the Science Museum. Science Education, v. 93, n.1, p.161-184, 2008. Disponível em: http://www.utsc.utoronto.ca/ dunbarlab/pubpdfs/4300636422417556957.pdf Acesso em: nov. 2013.

BARBEIRO, Luís Filipe de Oliveira. Aprendizagem em Ciência - a experiência e influência de uma visita de estudo escolar a um museu. 2007, 339 f. Dissertação (Mestrado em Comunicação e Educação em Ciência) - Universidade de Aveiro, Aveiro, 2007.

BIANCONI, M. L.; CARUSO, F. Educação não-formal. Cienc. Cult., São Paulo, v. 57, n. 4, dez. 2005. . Disponível em: http://cienciaecultura.bvs.br/scielo.php?script=sci_arttext\&pid=S000967252005000400013\&lng=en\&nrm=iso Acesso em: jul. 2013.

BIZERRA. A. Atividade de aprendizagem em museus de ciências. 2009. Tese (Doutorado em Educação) - Faculdade de Educação, Universidade de São Paulo, São Paulo, 2009.

BONI, V.; QUARESMA, S. J. Aprendendo a entrevistar: como fazer entrevistas em Ciências Sociais. Revista Eletrônica Em Tese, v.2, n.1, p. 68-80, 2005. Disponível em: https://periodicos.ufsc.br/index.php/emtese/article/viewFile/18027/16976 Acesso em: jan. 2014.

BORUN, M.; DRISTAS, J. Developing Family-Friendly Exhibits. Curator the Museum Journal, v. 40, n.3, p. 178-196, set. 1997. 
BRASIL. Resolução CONAMA n001 de janeiro de 1986. Define Impacto ambiental. Disponível em: http://www.mma.gov.br/port/conama/res/res86/res0186.html Acesso em: fev. 2014.

Resolução CONAMA no 266 de 03 de agosto de 2000. Estabelece diretrizes para a criação de Jardins Botânicos, normaliza o funcionamento desses e define seus objetivos.

BYBEE, R.W., Achieving Scientific Literacy. The Science Teacher, v. 62, n.7, p.28-33, 1995.

BYE, R. Historia de los jardines botánicos: evolución de estilos, ideas y funciones. Chapingo, v.2, p.43-53, 1994.

CAMPOS, Natália Ferreira. Análise das dimensões da biodiversidade presentes em materiais didático-culturais produzidos e/ou utilizados pelos museus de ciências. 2009, 62f. Monografia (Iniciação Científica) - Faculdade de Educação, Universidade de São Paulo, São Paulo, 2009.

CAZELLI, S.; FRANCO, C. Alfabetismo científico: novos desafios no contexto da globalização. Revista Ensaio - Pesquisa em Educação em Ciências, v.3, n.2, p.145159, 2001. Disponível em: http://cecimig.fae.ufmg.br/wpcontent/uploads/2007/12/sibelecreso.PDF. Acesso em: jul. 2013.

.; GOUVÊA, G.; FRANCO, C.; SOUZA, C. N. Padrões de Interação e Aprendizagem Compartilhada na Exposição Laboratório de Astronomia. Revista Brasileira de Estudos pedagógicos, v. 78, n. 188/189/190, p.413-471, jan./dez. 1997. Disponível em: http://www.emaberto.inep.gov.br/index.php/RBEP/article/viewFile/497/509. Acesso em jan. 2014.

Ciência, cultura, museus, jovens e escolas: quais as relações?. 2005, $260 f$. Tese (Doutorado em Educação) - Pontifícia Universidade Católica do Rio de Janeiro, Rio de Janeiro, 2005.

.; QUEIROZ, Glória; ALVES, Fátima; FALCÃO, Douglas; VALENTE, Maria Esther; GOUVÊA, Dominique Colinvaux. Tendências Pedagógicas das Exposições de um Museu de Ciência. In: SEMINÁRIO IMPLEMENTAÇÃO DE CENTROS E MUSEUS DE CIENCIAS, 1999, Rio de Janeiro. Anais... Rio de Janeiro, UFRJ, ago. $1999 . \quad$ Disponível em: http://www.casadaciencia.ufrj.br/Publicacoes/Artigos/Seminario/Art.Sem.Internacional. 99\%20Sibele.doc. Acesso em: fev. 2014. 
CERATI, Tânia M. Educação em jardins botânicos na perspectiva da Alfabetização Científica: análise de uma exposição e público. 2014. 254 f. Tese (Doutorado em Educação) - Faculdade de Educação, Universidade de São Paulo, São Paulo, 2014.

CLAYTON, S.; FRASER, J.; SAUNDERS, C. D. Zoo experiences: conversations, connections, and concern for animals. Zoo Biology, v. 28, p. 377-397, 2009.

CONSTANTIN, Ana C. Chaves. Museus Interativos de Ciências: Espaços complementares de educação?. Revista Interciencia, Caracas, v. 26, n. 5, p.195-200, mai. 2001. Disponível em: http://www.redalyc.org/pdf/339/33905604.pdf Acesso em: nov. 2013

CORREIA, F. Desenho Científico - o outro lado da comunicação científica. 2013. Disponível em: http://www.ilustracao-cientifica-uaveiro.com Acesso em: mai. 2014.

COUTINHO-SILVA, Robson et al. Interação museu de ciências-universidade: contribuições para o ensino não-formal de ciências. Cienc. Cult., São Paulo, v. 57, n. 4, dez. $2005 . \quad$ Disponível em: http://cienciaecultura.bvs.br/scielo.php?script=sci_arttext\&pid=S000967252005000400 015\&lng=en\&nrm=iso Acesso em: set 2014.

CROWLEY, K.; CALLANAN, M.A. Identifying and supporting shared scientific reasoning in parent-child interactions. Journal of Museum Education, v. 23, p. 12-17, 1998. Disponível em: http://www.lrdc.pitt.edu/mlc/documents/crowley6.pdf Acesso em jun. 2014.

CURY, M. X. Uma perspectiva teórica e metodológica para a pesquisa em recepção em museus. In: MARANDINO, M.; ALMEIDA, A. M.; VALENTE, M, A. E. (Org.). Museu: lugar do público. Rio de Janeiro: Fiocruz, 2009. p. 153-176.

DEBOER, G. E. Scientific literacy: Another look at its historical and contemporary meanings and its relationship to science education reform. Journal of Research in Science Teaching, v. 37, n. 6, p. 582-601, 2000.

DIAMOND, J. Practical Evaluation Guide - Tools for Museum \& Other Informal Educational Settings. New York, London: Rowman \& Littlefield, 1999.

DIERKING, L. The Role of Context in Children's Learning from Objects and Experiences. In: PARIS, S. (org.). Perspectives on object-centered learning in museums. London: Lawrence Erlbaum Associates, 2002. p. 3-18. 
; ELLENBOGEN, K.; FALK, J. In Principle, In Practice: Perspectives on a Decade of Museum Learning Research (1994-2004). Science Education, New York, v.88, 2004.

.; FALK, J. Family Behavior and Learning in Informal Science Settings: Review of the Research. Science Education, New York, v. 78, n. 1, p. 52-72, jan. 1994.

ELLENBOGEN, K.M. Museums in Family Life: An Ethnographic Case Study. In: LEINHARDT, G.; CROWLEY, K.; KNUTSON, K. (orgs.) Learning conversations in museums. Mahwah, NJ: Lawrence Erlbaum Associates, 2002.

FALK, J. H.; DIERKING, L. D. Lifelong Science Learning for Adults: The Role of FreeChoice Experiences. In: FRASER, B. J.; CAMPBELL, K. T.; MCROBBIE, J. Second International Handbook of Science Education. London, New York: Springer, 2012. v. 1, p. 1063-1134.

Learning from Museums: visitor experiences and the making of meaning. Walnut Creek, CA: Altamira Press, 2000.

The Museum Experience. Washington, DC: Whalesbak Books, 1992.

FEINSTEIN, N. Salvaging Science literacy. Science Education, v. 95, n.1, p. 168-185, 2011.

FELIPPE, G.; ZAIDAN, L.B.P. Do Éden ao Éden: jardins botânicos e a aventura das plantas. São Paulo: Senac São Paulo, 2008.

FREIRE, P. Educação como prática da liberdade. Rio de Janeiro: Paz e Terra, 1980.

. Pedagogia da autonomia: saberes necessários à prática educativa. São Paulo: Paz e Terra, 1996.

GIL, Antonio Carlos. Métodos e técnicas de pesquisa social. São Paulo: Atlas, 2008.

GRUZMAN, Carla; SIQUEIRA, Vera Helena F. de. O papel educacional do Museu de Ciências: desafios e transformações conceituais. Revista Electrónica de Enseñanza de las Ciencias, v. 6 , n. 2, p. 402-423, 2007. Disponível em: http://reec.uvigo.es/volumenes/volumen6/ART10_Vol6_N2.pdf. Acesso em: fev.2014. 
HEYWOOD, V.H. The changing role of the botanic garden. In: BRAMWELL, D. et al. (org.) Botanic Gardens and the World Conservation Strategy. London: Academic Press, 1987.

HILKE, D.D. Museums as resources for family learning: Turning the question around. The Museologist, v. 50, n.175, p.14-15, 1987.

HOEHNE, F. C. Os jardins e hortos botânicos. Revista Nacional, São Paulo, v. 2, n. 2, 1923.

; KUHlmanN, M.; HANDRO, O. O Jardim Botânico de São Paulo. São Paulo: Departamento de Botânica do Estado,1941.

ICOM. Disponível em: http://icom.museum/the-vision/museum-definition/ Acesso em: jun. 2013.

KRASILCHIK, Myriam. Caminhos do ensino de ciências no Brasil. Em Aberto, Brasília, n. $55, \quad$ p. 4-8, 1992. Disponível em: http://emaberto.inep.gov.br/index.php/emaberto/article/viewFile/811/729 Acesso em: jun. 2014 2004.

.; MARANDINO, Martha. Ensino de ciências e cidadania. São Paulo: Moderna,

LAUGKSCH, R.C. Scientific Literacy: A Conceptual Overview. Science Education, v.84, n.1, p. 71-94, 2000.

LEMKE, J.L. Investigar para el Futuro de la Educación Científica: Nuevas Formas de Aprender, Nuevas Formas de Vivir. Enseñanza de las Ciencias, v.24, n.1, p. 5-12, 2006.

LORENZETTI, L.; DELIZOICOV, D. Alfabetização Científica no Contexto das Séries Iniciais. Ensaio - Pesquisa em Educação em Ciências, v. 3, n. 1, p. 1- 17, jun. 2001. Disponível em: http://www.portal.fae.ufmg.br/seer/index.php/ensaio/article/viewFile/35/66 Acesso em dez. 2013.

LUCAS, A.M. "Infotainment" and informal sources for learning science. International Journal of Science Education, v. 1, n. 5, p. 495-504, 1991.

LUDKE, M. e ANDRÉ, M.E. D. A. Pesquisa em Educação: abordagens qualitativas. São Paulo: Ed. Pedagógica e Universitária, 1986. 
MARANDINO, M.; SILVEIRA, R. V. M.; CHELINI, M. J. E.; FERNANDES, A. B.; GARCIA, V. A. R.; MARTINS, L. C.; LOURENÇO, M. F.; FERNANDES, J. A.; FLORENTINO, H. A. A Educação Não Formal e a Divulgação Científica: o que pensa quem faz?. In: IV ENCONTRO NACIONAL DE PESQUISA EM ENSINO DE CIÊNCIAS - ENPEC, 2004, Bauru. Atas... Encontro Nacional de Pesquisa em Ensino de Ciências, IV, 2004a. Disponível em: http://paje.fe.usp.br/estrutura/geenf/textos/oquepensa_trabcongresso5.pdf Acesso em: jun. 2013.

Transposição ou recontextualização? Sobre a produção de saberes na educação em museus de ciências. Revista Brasileira de Educação, no 26, mai./ago. 2004b.

Museus de Ciências como Espaços de Educação. In: FIGUEIREDO, B. G.; VIDAL, D. G. Museus: dos Gabinetes de Curiosidades à Museologia Moderna. Belo Horizonte: Fino Traço Editora, 2005a. p. 165-176.

Educação em museus de história natural: Possibilidades e desafios de um programa de pesquisa. Enseñanza de Las Ciencias, 2005b.

Educação em museus e divulgação científica. ComCiência, Campinas, n. 100, 2008 . Disponível em: http://comciencia.scielo.br/scielo.php?script=sci arttext\&pid=S151976542008000300010\&lng=es\&nrm=iso Acesso em: jul. 2013.

Interfaces na Relação Museu-Escola. Caderno Brasileiro de Ensino de Física, v. 18, n.1, p.85-100, abr. 2001. Disponível em: https://150.162.1.115/index.php/fisica/article/viewFile/6692/6159. Acesso em: fev. 2014.

Por uma didática museal: propondo bases sociológicas e epistemológicas para análise da educação em museus. 2011, 236f. Tese (Livre-docência) - Faculdade de Educação, Universidade de São Paulo, São Paulo, 2011.

MARTINS, Heloisa Helena T. de Souza. Metodologia qualitativa de pesquisa. Educação e Pesquisa, São Paulo, v.30, n.2, p. 289-300, mai./ago. 2004.

MARTINS, Luciana Conrado. A constituição da educação em museus: o funcionamento do dispositivo pedagógico museal por meio de um estudo comparativo entre museus de artes plásticas, ciências humanas e ciência e tecnologia. 2011, 390f. Tese (Doutorado em Educação). - Faculdade de Educação, Universidade de São Paulo, 2011. 
MARTINS, Luciana Conrado; NAVAS, Ana Maria; CONTIER, Djana; SOUZA, Maria Paula Correia de. Que público é esse? Formação de públicos de museus e centros culturais. São Paulo: Percebe, 2013.

MCMANUS, P. What people say and how they think in a science museum. In: UZZELL, D. L. (org.) Heritage Interpretation: The visitor experience. London: Bellhaven, 1989. v. 2. p. 156-165.

MILLER, B.; CONWAY, W.; READING, R. P.; WEMMER, C.; WILDT, D.; KLEIMAN, D.; MONFORT, S.; RABINOWITZ, A.; ARMSTRONG, B.; HUTCHINS, M. Evaluating the Conservation Mission of Zoos, Aquariums, Botanical Gardens, and Natural History Museums. Conservation Biology, v. 18, p. 86-93, 2004.

MOREIRA, Marco Antonio. Pesquisa em ensino: aspectos metodológicos (Texto de Apoio $\mathrm{n}^{\circ}$ 19). Universidade Federal do Rio Grande do Sul. Porto Alegre, 2013. Disponível em: http://www.if.ufrgs.br/ moreira/pesquisaemensino.pdf. Acesso em: junho de 2013.

NASCIMENTO, Tatiana Galieta; REZENDE JUNIOR, Mikael Frank. A produção sobre divulgação científica na área de educação em ciências: referenciais teóricos e principais temáticas. Investigações em Ensino de Ciências, v.15, n.1, p. 97-120, 2010.

NICBIO. Núcleo de Ilustração da Universidade de Brasília. Disponível em: http://nicbio.unb.br/ Acesso em: ago. 2013.

PÉREZ, C. A. MOLINI, A. M. V. Consideraciones generales sobre la alfabetización científica en los museos de la ciencia como espacios educativos no formales. Revista Electrónica de Enseñanza de las Ciencias, v. 3, n. 3, 2004.

PIANA, MC. A construção do perfil do assistente social no cenário educacional. São Paulo: Editora UNESP; Cultura Acadêmica, 2009. Disponível em: http://books.scielo.org/id/vwc8g/pdf/piana-9788579830389-05.pdf Acesso em: out. 2013.

RENNIE, L.J. Learning science outside of school. In: ABELL, S. K.; LEDERMAN, N. G. Handbook of Research on Science Education. Mahwah: N.J. Lawrence Erlbaum Associates, 2007.

ROBERTS, D.A. Scientific Literacy/Science Literacy. In: ABELL, S.K.; LEDERMAN, N.G. Handbook of Research in Science Teaching and Learning. New York: McMillan, 2007. 
SANDER, Roberto. O museu na perspectiva da educação não-formal e as tendências políticas para o campo da museologia. 2006. 101f. Dissertação (Mestrado em Educação) - Faculdade de Passo Fundo, Passado Fundo, 2006. Disponível em: http://www.ppgedu.upf.br/index.php?option=com_docman\&task=doc_download\&gid= 137 Acesso em nov. 2013.

SÃO PAUlO (Estado). Secretaria do Meio Ambiente. Cadernos da Mata Ciliar (nº 1 ). São Paulo, 2009. Disponível em: http://www.ambiente.sp.gov.br/municipioverdeazul/files/2013/05/Cadernos-de-MataCiliar-1_Preserva\%C3\%A7\%C3\%A3o-e-recupera\%C3\%A7\%C3\%A3o-denascentes_2004.pdf Acesso em: set. 2013.

SASSERON, Lúcia Helena. Alfabetização Científica no Ensino Fundamental: Estrutura e Indicadores deste processo em sala de aula. 2008, 265f. Tese (Doutorado em Educação) - Faculdade de Educação, Universidade de São Paulo, São Paulo, 2008.

.; CARVALHO, A. M. P. Escrita e Desenho: análise de registros elaborados por alunos do Ensino Fundamental em aulas de Ciências. Revista Brasileira de Pesquisa em Educação em Ciências, v. 10, p. 1-19, 2010.

; CARVALHO, A.M.P. Alfabetização Científica: Uma Revisão Bibliográfica. Investigações em Ensino de Ciências, v.16, n.1, p. 59-77, 2011.

SEGARRA, A., VILCHES, A. y GIL, D. Los museos de ciencias como instrumentos de alfabetización científica. Didáctica de las Ciencias Experimentales y Sociales, n. 22, p. $85-102,2008$.

SIQUEIRA, J.C. O Jardim Botânico do Rio de Janeiro: uma lembrança do 1. Centenário (1808-1908). Rio de Janeiro: Banco Safra, 1998.

SOUZA, Maria Paula Correia. O papel educativo dos Jardins Botânicos: análise das ações educativas do Jardim Botânico do Rio de Janeiro. 2009, 154f. Dissertação (Mestrado em Educação) - Faculdade de Educação, Universidade de São Paulo, 2009.

SUGUITURU, S. S.; MORINI, M. S. C. Arte e Ciência: Uso de diferentes técnicas de Ilustração Científica. In: XV CONGRESSO DE INICIAÇÃO, 2012, Mogi das Cruzes. Anais... Mogi das Cruzes, UMC, 2012. Disponível em: http://www.umc.br/_imgs/XV_congresso/artigos/Silvia\%20Sayuri\%20Suguituru.pdf Acesso em: jan. 2014.

VIEIRA, Valéria; BIANCONI, M. Lucia; DIAS, Monique. Espaços Não-formais de ensino EO Currículo de Ciências. Cienc. Cult., São Paulo, v. 57, n. 4, dez. 2005. 
ZUIN, V. G; FREITAS, D. de; OLIVEIRA, M. R. G. de; PRUDÊNCIO, C. A. V. Análise da perspectiva da ciência, tecnologia e sociedade em materiais didáticos. Ciências \& Cognição, v.13, n.1, p. 56-64, 2008. 


\section{APÊNDICES}

\section{APÊNDICE A - Tópicos-guia para a realização da entrevista}

\section{Dados iniciais}

- Data

- Tempo aproximado de duração da visita à exposição

- Horário da entrevista / duração

\section{Identificação do grupo}

- Número de participantes

- Nomes e idade;

- Nível de escolaridade

- Área de formação

- Profissão do $(\mathrm{a} / \mathrm{s})$ responsáveis

\section{Hábitos de visitas a museus e parques}

- Que atividades de lazer vocês costumam realizar? Por que?

- Vocês frequentam museus, Zoológicos, Jardins Botânicos? Dê exemplos. Com qual frequência? Em grupo, sozinho ou com a família?

- Antes de visitar esses espaços vocês se informam? Para que? Onde?

\section{Conhecimento sobre a exposição}

- Vocês buscaram informações para essa visita?

- Vocês já conheciam a Trilha da Nascente?

Percepções sobre o material fornecido, aspectos de uso das informações disponibilizadas no roteiro e Indicadores de Alfabetização Científica

- Vocês acham que o material fornecido auxiliou a visita? Como?

- Especialmente o roteiro, auxiliou? Como?

- Vocês tiveram alguma dificuldade de utilização? Descreva.

- Observaram as placas ao longo da trilha? Leram as placas? Em que momentos?

- O que vocês mais gostaram na trilha? Por que?

- Como você se sentiu ao longo da trilha? Do ponto de vista sensorial e emocional, como foi sua visita? Descreva?

- Algum detalhe da visita foi especialmente marcante? Por que? 
- Ao longo visita vocês tiveram acesso a conhecimentos que poderão ser levados para sua vida? Quais?

- Que novas informações você obteve?

- Qual o papel social do JB? Como você percebeu isso?

- Qual o papel da Trilha da Nascente para o JB? E para a cidade de São Paulo? Por que?

- A Trilha da Nascente promove a conservação do meio ambiente? Como?

- Que contribuição científica a trilha oferece? Por que? Como?

- Você utilizou os instrumentos fornecidos no material (lupa, monóculo)? Como?

- Qual a importância desses instrumentos nessa visita?

- Vocês acham que a trilha é usada para o desenvolvimento de pesquisas científicas? Por quê?

- Vocês compreenderam o desafio proposto no roteiro? Encontraram subsídios para responde-lo? Exemplifique

- Ao final, o roteiro solicita uma reflexão sobre a interação entre o ser humano e a trilha. Que aspectos surgiram ou foram pensados nesse momento?

- O que vocês registraram no roteiro no espaço para impressões e percepções? Por quê?

- Vocês têm alguma sugestão para essa experiência dessa visita com o material fornecido? 


\section{APÊNDICE B - Autorização para o uso de imagem}

\section{$\cdot \boldsymbol{F E} \mathbb{S} \mathbb{P}$}

\section{TERMO DE CONSENTIMENTO LIVRE E ESCLARECIDO}

Você e a sua família estão sendo convidados para participar, como voluntários, na pesquisa "Estudando a Alfabetização Científica por meio de visita roteirizada a uma exposição de Jardim Botânico", da aluna do Programa de Pós Graduação Interunidades em Ensino de Ciências da Universidade de São Paulo, Juliana Rodrigues. Após serem esclarecidos sobre as informações a seguir, no caso de aceitar fazer parte do estudo, assine ao final deste documento, que está em duas vias. Uma delas é de vocês e a outra é da pesquisadora responsável.

\section{DESCRIÇÃO DA PESQUISA}

Projeto: "Estudando a Alfabetização Científica por meio de visita roteirizada a uma exposição de Jardim Botânico"

Instituição: Universidade de São Paulo

Pesquisadora responsável: Juliana Rodrigues

Orientadora: Martha Marandino

Instituição: Faculdade de Educação da Universidade de São Paulo

Telefones: (+55 11) 3091-2404 / 3091-8265

E-mails: julianacr@usp.br / marmaran@usp.br

O projeto busca analisar o processo de Alfabetização Científica a partir da produção de um roteiro de visita que possa promover educação em museus.

Para esta pesquisa serão feitas observações, fotos, gravações e filmagens, além da entrevista aos sujeitos a ser registrada em áudio e vídeo.

Atestamos que as identidades de todos os sujeitos da pesquisa serão preservadas, buscando-se evitar qualquer constrangimento, e que nenhuma informação sobre os sujeitos será revelada a terceiros e nem será usada para fins pessoais ou políticos. Serão mantidos no anonimato os materiais escritos e verbais dessa pesquisa, além da não veiculação das imagens dos sujeitos.

Os dados coletados nessa pesquisa, registrados em áudio, vídeo e fotografia, serão utilizadas somente para os fins de pesquisa, na publicação da tese e de artigos, além de outros meios de divulgação, como revistas, jornais, congressos, eventos científicos e demais formas de divulgação e educação em material impresso ou digital, sem limitação de tempo ou de número de exibições. 
A guarda dos dados coletados e do material utilizado na pesquisa é de inteira responsabilidade Grupo de Estudo e Pesquisa em Educação Não Formal e Divulgação da Ciência/GEENF.

Você pode recusar-se a participar, ou mesmo desistir a qualquer momento sem que isto acarrete qualquer ônus ou prejuízo à sua pessoa. E sendo um participante voluntário, você não terá nenhum pagamento e/ou despesa referente à sua participação no estudo.

Caso você tenha dúvidas ou necessite de maiores esclarecimentos pode nos contatar por meio dos dados fornecidos na descrição da pesquisa.

Este termo será preenchido em duas vias de igual teor, e uma será entregue a você.

$\mathrm{Eu}$, $\mathrm{RG}$ concordo em participar como voluntário(a) da pesquisa "Estudando a Alfabetização Científica por meio de visita roteirizada a uma exposição de Jardim Botânico", como sujeito. A assinatura dos demais integrantes da minha família se fará presente no Formulário de Consentimento para Participação em Pesquisa e, quando houver impossibilidade por restrição de idade, eu assinarei enquanto responsável legal. Afirmo que fomos devidamente informados e esclarecidos pela pesquisadora Juliana Rodrigues sobre a finalidade e objetivos desta pesquisa, bem como sobre a utilização das informações. Meu nome e o da minha família não serão divulgados de forma nenhuma e terei a opção de retirar meu consentimento a qualquer momento.

São Paulo, de de 2015 .

Sujeito / responsável

Pesquisadora 


\section{APÊNDICE C - Formulário de Consentimento para Participação em Pesquisa}

Título da pesquisa: "Estudando a Alfabetização Científica por meio de visita roteirizada a uma exposição de Jardim Botânico"

EU CONCEDO POR MEIO DESTE, abaixo assinado, à pesquisadora que conduz este projeto o direito de usar a minha imagem, e/ou voz, e/ou palavras em vídeo, áudio, fotografia para o uso em fins de pesquisa incluindo apresentações, artigos de jornal e revista, e capítulos de livro, sem limite de tempo ou uso.

\begin{tabular}{|l|l|l|}
\hline Nome & \multicolumn{2}{|c|}{} \\
\hline Assinatura & \\
\hline Data & \\
\hline
\end{tabular}

\begin{tabular}{|l|l|}
\hline Nome & \multicolumn{2}{|c|}{} \\
\hline Assinatura & \\
\hline Data & $/$ \\
\hline
\end{tabular}

\begin{tabular}{|l|l|}
\hline Nome & \multicolumn{2}{|}{} \\
\hline Assinatura & \\
\hline Data & \\
\hline
\end{tabular}

\begin{tabular}{|l|l|l|}
\hline Nome & \multicolumn{2}{|c|}{} \\
\hline Assinatura & \multicolumn{2}{|c|}{} \\
\hline Data & $/$ \\
\hline
\end{tabular}

\begin{tabular}{|l|l|}
\hline Nome & \multicolumn{2}{|c|}{} \\
\hline Assinatura & \\
\hline Data & \\
\hline
\end{tabular}

\begin{tabular}{|l|l|}
\hline Nome & \multicolumn{2}{|c|}{} \\
\hline Assinatura & \multicolumn{2}{|c|}{} \\
\hline Data & \\
\hline
\end{tabular}

\begin{tabular}{|l|l|l|}
\hline Nome & \multicolumn{2}{|c|}{} \\
\hline Assinatura & \multicolumn{2}{|c|}{} \\
\hline Data & $/$ \\
\hline
\end{tabular}

\begin{tabular}{|l|l|l|}
\hline Nome & \multicolumn{2}{|c|}{} \\
\hline Assinatura & \\
\hline Data & \\
\hline
\end{tabular}




\section{APÊNDICE D - Transcrição total da fala dos participantes da pesquisa}

\section{(Turno - Locutor - Fala)}

001 - MARIA - Olha, Antonia, vamos ver se a gente consegue ver esse bichinho aqui?

Eu tô louca pra ver esse bichinho aqui ó. Esse bichinho aqui é o bichinho preguiça. É a cara da Antonia. Esse aqui é o beija-flor, está vendo que bonitinho? ((aponta para a placa 01))

002 - ANTONIA - Ahan. E esse é um (pardo passarinho) (incompreensível).

003 - MARIA - Tá parecendo com o seu. Você não tem um passarinho desse em casa?

004 - ANTONIA - Eu tenho um azul e um amarelo. Eu não tenho verde não.

005 - MARIA - A gente vai encontrar a família deles aqui. (+) Tá ouvindo?

006 - ANTONIA - É a gente andando!

007 - LAURA e MARIA - ((risos))

008 - MARIA - Olha! Escutou? O silêncio? Aqui eles estão dormindo... ((diz sussurrando))

009 - LAURA - Olha, Antonia, está tudo no alto. Você viu onde a gente está? Olha lá pra baixo, tem um monte de coisa pequenininha.

010 - ANTONIA - Bem pequenininho...

011 - MARIA - Legal explorar aqui, né? (+) Bonitinho... pensei que era um bicho, né. Mas não é; era uma planta.

012 - ANTONIA - O macaquinho? (++) Ai, eu ainda tô com frio...

013 - MARIA - Eu vou ter que chamar ele, né?

014 - LAURA - Abertura de clareiras... ((pára rapidamente em frente à placa $\mathrm{n}^{\circ} 02$ e lê em voz alta))

015 - ANTONIA - Mamãe, eu tô com frio!

016 - LAURA - Olha o Sol aqui; vem cá.

017 - MARIA - Tá ouvindo o macaco? Tá ouvindo? Ó, o macaco, Antonia! Ah, que pena, você não olhou, correu! ((risos))

018 - LAURA - Olha, Antonia, a árvore ficou no meio do caminho.

019 - MARIA - Que bonitinho, Antonia, olha. Ele passou e depois passou uma outra vez. Que da hora. (++). Deixa eu ver - tem a placa 01, placa 02, só não estou vendo a placa aqui. Mas vamos ver...

020 - ANTONIA - Mãe, olha eu saiu dali e tô com frio

021 - MARIA - Vamo, Antonia, vamo 
022 - LAURA - Vai esquentar...

023 - MARIA - Vamos que daqui a pouco a gente vai ver os macaquinhos.

024 - ANTONIA - Mãe, eu não sei, começou o tanto de animal.

025 - MARIA - Ai que bonitinho!

026 - LAURA - Tá bem no alto, né?

027 - MARIA - Ainda bem que aqui não tem bicho selvagem, né? Porque senão aí, meu

Deus, aí eu não ia saber chorar ou sorria. Ser comida por um bicho selvagem ((risos))

028 - ANTONIA - Ã:: ((com voz de choro)) (+) Mã::e

029 - MARIA - O que foi?

030 - ANTONIA - Eu quero a minha blusa

031 - MARIA - Você tá com frio? Mas a gente nem viu o macaco ainda...você nem viu que o macaco correu!

032 - ANTONIA - Mãe, você me dá minha blusa?

033 - LAURA - Aqui está mais frio que lá, né? ((abriu a mochila, pegou e entregou a blusa a Antonia))

034 - MARIA - Você viu isso aqui, ó, tem um corregozinho?

035 - LAURA - Tem?

036 - MARIA - Tem ó; ó que bonitinho! É a nascente do rio. Tá vendo ali, ó?

037 - LAURA - Olha, é verdade!

038 - MARIA - É onde a gente viu aquele laguinho lá que tava o bichinho. A água sai dali, ó.

039 - LAURA - Daqui ele vai pra lá?

040 - MARIA - Vai, ó. Tá vendo que bonitinho?A água sai daqui ó; que você tava com medo da água. Bem bonitinho, ó, tá vendo? (+) Eu acho que os bichinhos estão dormindo, por isso que eles não apareceram. Tem que ficar de olho ó, pra a gente ver o bichinho preguiça... É que o bichinho preguiça, ele fica lá:: em cima. Ele só vem pra comer, eu acho.

041 - LAURA - Viu que não pode cortar árvore? (Ele) (incompreensível) fica em volta ((se referindo à arvore mantida no percurso da trilha))

042 - MARIA - Olha lá o macaquinho, Antonia. Eu achei! Olha lá, um monte! Ali onde aquele homem está! Olha lá, olha lá, Antonia. Olha. Que bonitinho! É o macaquinho...deixa eu ver o nome desse macaquinho ((consulta o roteiro)). Olha lá, olha. 043 - ANTONIA - Mãe! É o ma-ca-qui-nho! ((sussurrando)) 044 - MARIA - Não é não; é o macaco, Antonia. Ah, que lindo! 
045 - ANTONIA - Ele ficou lá no alto.

046 - MARIA - Cadê o outro?

047 - LAURA - Tá ali; tá tudo ali em cima.

048 - MARIA - Eita, parece o teu pai, óia, uma preguiça só.

049 - ANTONIA - Ele se jogou, já

050 - MARIA - Aqui, ó, aqui, aqui ó. psiu, psiu. Chama o macaquinho - psiu, psiu. Vixe, tem um monte, amor, olha! Que lindo aqui! Psiu, psiu, chama ele. Faz assim que ele vê. 051 - LAURA - psiu, psiu.

052 - ANTONIA - Agh, agh ((imitando o som do macaquinho))

053 - MARIA - ((risos)). Olha que bonitinho.

054 - LAURA - Búgios.

055 - MARIA - Os Búgios são estes daqui?

056 - ANTONIA - Sabe por que ele está de ponta cabeça? Porque ele segura o rabo.

057 - MARIA - Sabe o que eles gostam de comer? Sabe o que eles gostam de comer? Eles gostam de comer frutinhas.

058 - LAURA - Olha lá, tem um monte comendo

059 - MARIA - Frutinha vermelha, ó, aqui ó.

060 - LAURA - Um monte de frutinhas...

061 - MARIA - E eles não andam assim no chão ó. Eles só andam nas árvores porque eles têm medo das pessoas então eles ficam lá em cima.

062 - LAURA - Ah, que legal!

063 - MARIA - Não é lindo? (+). Vamos, vamos ver se a gente encontra o bichinho preguiça?

064 - LAURA - Viu, a gente já encontrou um bichinho diferente...

065 - MARIA - Você viu? A gente já encontrou dois macacos

066 - ANTONIA - Éééé.

067 - MARIA - Que comem frutinhas vermelhas. (++). Fica aqui. Peraí. Vai que a gente encontra um bicho aí. Vai que a gente encontra uma poça de água, porque o seu medo é água. Não sei como é que pode uma criança ter medo de água. Enfim, há gente doida pra tudo, né?

068 - ANTONIA - Vamos ver aí em cima. A gente vê o bicho.

069 - MARIA - Ah! Sabe que eu esqueci? De usar o binóculo. Dá pra ver o bichinho melhor. Nem lembrei do binóculo.

070 - LAURA - Então. 
071 - MARIA - Vem cá, Antonia. Tem um binóculo aqui que vai dar para gente ver as coisas melhor. Ó, vou ensinar você ver isso aqui. Dá pra gente ver de longe. Eu tinha que ter usado o binóculo; esqueci do binóculo! A gente ficou tão encantada pra ver o bichinho ((risos)). A emoção foi muito grande.

072 - LAURA - Ali tem a placa falando as coisas que a gente viu agora pouco.

073 - MARIA - A gente consegue ver alguma coisa agora.

074 - ANTONIA - Mãe, olha um quadradentro ((incompreensível)) aqui no meio.

075 - MARIA - Ah, agora não vai dar pra gente ver nada, porque não tem nada.

076 - LAURA - Viu? Não pode cortar as árvores.

077 - ANTONIA - Vi. Por que elas crescem lá no alto.

078 - LAURA - Olha essa que grandona ((referindo-se a uma árvore)), ela dá toda a volta.

Ó que grandona!

079 - ANTONIA - É.

080 - MARIA - Cê vê como ela é bem alta? Você consegue pegar? Lá, ó, onde ela chega?

081 - LAURA - Você viu?

082 - MARIA - Você está escutando?

083 - ANTONIA - Mãe, sabe por que não pode cortar as árvores?

084 - LAURA - Por quê?

085 - ANTONIA - Porque o macaco cai triste se tiver onde está cortando a casa.

086 - LAURA - Isso mesmo, a casa do macaquinho é na árvore. Não pode cortar.

087 - ANTONIA - É. Não pode cortar a árvore. A árvore é feita pros macaquinhos.

088 - MARIA - Vem cá, vamos dar uma olhada aqui.

089 - LAURA - Aqui. Vamos ver o que tem. Aqui mais uma. Nossa, que árvore alta!

090 - ANTONIA - Ahã. (++). Olha, ali é o bicho preguiça.

091 - LAURA - Esse é o que a gente viu. Esse é o Bugio.

092 - MARIA - É esse é o bugios. É aquele que a gente viu de longe.

093 - ANTONIA - Não tem só esse.

094 - MARIA - É só pra gente ver. Ver a natureza! Vamos ver se a gente vê outro bicho aqui.

095 - ANTONIA - É o bicho preto?

096 - LAURA - Deu pra ver ele se pendurando.

097 - ANTONIA - Eu vi um por aqui.

098 - MARIA - A gente ainda vai encontrar uma preguiça, porque a preguiça é uma preguiça. 
099 - ANTONIA - O que a preguiça é?

100 - MARIA - É um bichinho que tem muita, muita preguiça.

101 - ANTONIA - Ahã. Já vi.

102 - LAURA - ((risos)). Você já viu? (++) Ele é bem mais baixo, tá vendo?

103 - MARIA - Olha que legal aqui, ó, vem cá que eu vou mostrar uma coisa pra você pra ver, ó. Se você consegue ver naquela direção ele ali? As frutinhas que um macaquinho gosta de comer. Vamos ver se dá pra ver daqui com o binóculo. Peraí, deixa eu sintonizar aqui o binóculo. Não, mas se você ficar aqui na frente não dá, não dá pra tia ver nada mesmo, vai ficar pouco assim meia - Uau! Não, não. Peraí ó.

104 - LAURA - Deixa eu te mostrar.

105 - MARIA - Mas não vai cair embaixo, se não a gente vai perder você, aí minha filha, eu vou ter que rir, que, quando fico nervosa, eu dou risada. Ai Meu Deus, perder a menina na excursão, aí já viu. Peraí, deixa, eu tinha aumentado muito o binóculo.

106 - LAURA - É cunhada, a gente tá passando aí o colorido de árvore.

107 - MARIA - Cê viu, que legal?

108 - ANTONIA - Tá.

109 - LAURA - Tá cheio de passarinho na árvore.

110 - MARIA - Óh, é a frutinha do macaco, mesmo, porque é bem vermelhinha. Peraí, deixa a tia ver aonde que tá, primeiro. Ah! Tá ali, ó, olha aqui, lá em cima, tá vendo? Frutinha vermelhinha?

111 - ANTONIA - Não. Não tô vendo nada.

112 - MARIA - Aqui ó. Conseguiu ver?

113 - ANTONIA - Não. Tá cheio de fumaça.

114 - LAURA e MARIA - ((risos))

115 - MARIA - Não, não é, ó.

116 - LAURA - Dá pra ela que ela procura sozinha.

117 - MARIA - Ó, é a frutinha do macaco ela é bem vermelhinha. Aqui, ó, lá em cima tá vendo?

118 - LAURA - É, tá bem vermelhinha.

119 - MARIA - Elas são bem vermelhinhas, Laura

120 - LAURA - São. Ah! Lá na pontinha.

121 - MARIA - Ela é bem vermelhinha.

122 - LAURA - É da cor do macaco

123 - MARIA - Bem, eu não sei onde você tá olhando, mas é ali... 
124 - LAURA - ((risos))

125 - MARIA - aquelas ali... frutinhas, olha. É que você está olhando.

126 - LAURA - O senso de direção dela não permite

127 - LAURA e MARIA - ((risos))

128 - ANTONIA - Tá tudo colorido.

129 - MARIA - É. Na sua visão tudo é colorido mesmo, mas na verdade, é. Daqui, deixa a tia ver. Quer ver, Laura?

130 - ANTONIA - Ah, tô vendo, vi.

131 - MARIA - Você viu? Você viu a frutinha? Calma... Tá olhando certo? Achou, minha filha! Quase me arrancou e joga lá dentro... Viu?

132 - ANTONIA - Alí ó

133 - MARIA - É então, aquela frutinha ela é bem vermelhinha. Viu? Um monte. Aí eles fica pulando para comer essas frutinhas. (+). Agora vamos? Vamos ver outros bichinhos? Vem.

134 - ANTONIA - Vamos.

135 - MARIA - Da hora! Essa aqui sabe ser bem natural ((risos)). Se você quer contar um segredo, se conta pra Antonia.

136 - LAURA - Conta.

137 - MARIA - Ninguém vai ficar sabendo. Só o planeta.

138 - ANTONIA - Ai, para gente!

139 - MARIA - ((risos)). Tira a mão do microfone, ô coisa louca!

140 - ANTONIA - Ahaha

141 - MARIA - ((risos)) Ela não contente ainda, ela ainda pega microfone. ((risos))

142 - LAURA - Tá "se sentindo" ((risos))

143 - ANTONIA - Ai Cal...

144 - MARIA - Tá bom, agora não tem mais graça, não. Vamos continuar vendo aqui que tem muita coisa legal aqui.

145 - ANTONIA - Ah! Posso segurar o binóculo?

146 - MARIA - Pode, mas você põe a mão assim ó pega assim, ó, enfia a mão e olha.

147 - ANTONIA - Solta!

148 - MARIA - E não vai quebrar o binóculo. Segura.

149 - ANTONIA - Mãe! Olha... (?) É porque tá parecendo um casaco. Ah, ... (incompreensível) dando um beijo na boca. 
150 - MARIA - Eu gostei de ver a frutinha do macaquinho. "Da hora' aqui. (+) Ó, deixa eu te falar um negócio que você não pode fazer, quando você vem na floresta, não pode fazer isso, tá vendo ali?

151 - ANTONIA - Tô.

152 - MARIA - Aqui, perto das árvores tem uma garrafa "Dolly", tá vendo? Não pode jogar sujeira na natureza, se não contamina a natureza e ai os bichinhos, depois, não tem o que comer, porque sujeira suja tudo. Onde a gente joga a sujeira?

153 - ANTONIA - No lixo!

154 - MARIA - Isso mesmo!

155 - LAURA - Olha, ela é fofinha ((se referindo a garrafa)), parece um ursinho, fofinho isso aqui. O musgo colou nela, ó parece de pelinho.

156 - MARIA - Legal, né?

157 - ANTONIA - Ééé.

158 - LAURA - Tá vendo? Igual seu cachorrinho fofinho.

159 - ANTONIA - Eu não tenho cachorrinho.

160 - LAURA - Claro que tem.

161 - MARIA - Mas pra que, que precisa? (+). Muito legal, né? Ó, esse aqui é um Cipó. O macaquinho desce por aqui também quando não tem gente aqui no parque.

162 - LAURA - Viu que grandão?

163 - MARIA - Legal, né? A gente ainda vai ver a bichinha preguiça.

164 - ANTONIA - É. Se ele escorregar, ele vai pra longe...

165 - MARIA - É, eles não ficam andando muito ali não porque tem alguns bichinhos aí que podem machucar ele, tem uns bichinhos que gostam de andar aqui. Bem legal. Deixa eu ver mais o que a gente tem aqui no negócio, pra gente ver.

166 - ANTONIA - Eu vou procurar alguma coisa...

167 - MARIA - O que você vai procurar?

168 - ANTONIA - Vou procurar algum bichinho. É você tá na frente.

169 - MARIA - Deixa eu ver onde a gente está aqui. (+). Olha, a gente já viu o macaco... ((olhando no roteiro))

170 - ANTONIA - Tem nada, nada ainda.

171 - MARIA - Sabe o que parece isso aqui, Laura?

172 - LAURA - Sim.

173 - MARIA - Vitiligo. ((risos)). Ó, olha aqui a bichinha toda manchada, tá vendo? Legal? 
174 - ANTONIA - Hum

175 - MARIA - Ah, é sim!

176 - ANTONIA - Aqui é um vermelho, é tinta ó.

177 - MARIA - É na verdade, aqui no vermelho, tá falando que é boa qualidade do ar. Vamos ver esse negócio vermelho? Tem uma lupa que dá pra ver. Peraí, dá pra ver a qualidade do ar aqui, ó, no negócinho vermelho.

178 - ANTONIA - Aqui.

179 - MARIA - Calma, deixa a tia pegar aqui a lupinha. Que legal!

180 - ANTONIA - É pra nós duas?

181 - MARIA - É. Mas vai usar só uma, senão você cai lá dentro, cai a lupa também.

182 - LAURA - Ah, o vermelhinho ali é igual?

183 - MARIA - É.

184 - LAURA - Vem cá, Antonia.

185 - MARIA - Aqui tá falando que a bichinha tem saúde. Que interessante!

186 - LAURA - Põe isso aqui no braço.

187 - MARIA - Ó, segura. Qualquer coisa você joga ela. ((risos)). Pra pegá.((risos)) Viu?

Esse aqui ó. Esse negocinho vermelho, aqui ó.

188 - LAURA - Põe o pé ai.

189 - ANTONIA - Não! Não quero mais ver. Não quero ver! Não quero ver.

190 - LAURA e MARIA - ((risos))

191 - LAURA - Põe o pé ai, Antonia, que eu seguro.

192 - MARIA - Calma, calma. A sua mãe não vai deixar você cair. É só você pra olhar isso aqui ó, esse vermelho, ó.

193 - LAURA - É a qualidade do ar?

194 - MARIA - É. Está escrito aqui que é a qualidade do ar, significa que aqui, aqui.

195 - ANTONIA - Eu quero sair.

196 - LAURA - Ah já tá bom, né?

197 - MARIA - Aqui ó - O que são as manchas coloridas em torno das árvores? Diga! Tá aqui que é para olhar com a lupa.

198 - ANTONIA - Ah, eu tô vendo agora.

199 - LAURA - Ah. Que legal.

200 - MARIA - Tá escrito aqui ó - Sua presença indica que é a qualidade do ar está boa.

201 - ANTONIA - Mãe, eu já vi.

202 - MARIA - Viu? Dá pra ver aqui 
203 - ANTONIA - Ahã, vi. Você deixa caí.

204 - MARIA - Ó tem umas árvores que eu quero ver, que tem em nosso cabelo, tá dizendo que tem uns cachos na mata.

205 - ANTONIA - Deixa eu vou ver?

206 - MARIA - Aqui ó, a gente vai procurar aqui "us lugar" que tenha cabelo igual ao nosso.

207 - ANTONIA - Isso diz...

208 - MARIA - Agora dá aqui pra tia, aqui, dá pra tia segurar. Nossa, se já tá segurando na lupa. Dá aqui, tá vendo?

209 - ANTONIA - Eu tô vendo pio de passarinho.

210 - LAURA - Também.

211 - ANTONIA - Mãe, vamo

212 - LAURA - Tinha que ser.

213 - MARIA - Aquilo ali é uma pedra? Ou é um ovo?

214 - LAURA - Não sei.

215 - ANTONIA - Deixa eu ver

216 - LAURA - Ovo?

217 - MARIA - É, aquela coisa branca ali.

218 - LAURA - Sei lá. Parece que é pedra.

219 - ANTONIA - É um papel. Não gente, é um papel. É, num pode jogar ali. Olha tem outro papel!

220 - MARIA - Será? pra mim, eu pensei que era um ovo. Tem.

221 - ANTONIA - Tem dois!

222 - MARIA - Vamos que eu quero achar aquelas árvores lá.

223 - LAURA - No meio do nada, tem um ovo

224 - MARIA - Sei lá, bem saudável. Sei. Vem Antonia! (++) No meio do nada.

225 - ANTONIA - Vem ver, vem ver, titia! É um papel, vem ver. Um papel! Ve::m.

226 - MARIA - O que? Você quer ver o papel, minha filha?

227 - ANTONIA - Tá ali, ó.

228 - MARIA - Deixa a tia ver. (+) Não, Antonia. É uma pedra.

229 - ANTONIA - Mas ela tá cortadinha. Deixa eu ver.

230 - MARIA - Aquilo ali é um papel? Aquilo ali é uma pedra.

231 - ANTONIA - Num sei, redondinha (?)

232 - MARIA - Viu? 
233 - ANTONIA - Ainda não.

234 - MARIA - Vamo?

235 - ANTONIA - É um papel.

236 - MARIA - Vamo, que tem muita coisa legal pra gente ver ainda.

237 - ANTONIA - Tem. É um papel.

238 - MARIA - Tá bom, chega, bora! Ó, vamos ver a natureza. É papel porque alguma pessoa jogou lá em baixo. Não pode maltratar a natureza; a natura demora muito tempo para desmanchar o papel, ai os bichinhos vão ficar sem o que comer. Vem, vamos dar uma olhada aqui. Não é pra olhar “os papel”. Ó o rio, ó.

239 - LAURA - Olha aqui Antonia o que a gente acabou de ver, o vermelhinho, né?

240 - ANTONIA - Deixa eu ver?

241 - MARIA - Aqui ó.

242 - LAURA - E o lagartinho que a gente viu.

243 - MARIA - Olha que bonitinho.

244 - LAURA - O (Dijeam) (incompreensível).

245 - MARIA - Ó, o cogumelo que a tia mostrou pra você.

246 - LAURA - Tem 1.200 espécies de plantas, com flor.

247 - ANTONIA - A gente já viu esse.

248 - MARIA - E vimo aqui esse aqui, ó.

249 - ANTONIA - Vimos esse e vimos esse e pronto,

250 - MARIA - Se viu? Muito da hora, né?

251 - ANTONIA - Vamos ver lá de cima. Ô mamãe - o que é isso daqui?

252 - LAURA - É um lagarto.

253 - ANTONIA - Um lagarto?

254 - LAURA - Um lagartinho e são coloridas. Tem um monte nas árvores.

255 - MARIA - Eu acho que a gente ainda vai ver um bicho preguiça. (+) É que gente ainda chegou na casa

256 - LAURA - Esperança não morre.

257 - MARIA - Tá escutando, Antonia?

258 - ANTONIA - Deixa eu ver ((sussurrando))

259 - MARIA - Ó, continua, ó, da nascente do rio, tá vendo, ó? Aqui é onde riozinho nasce.

260 - LAURA - É bem devagarinho.

261 - MARIA - É bem devagarinho! 
262 - LAURA - Estão subindo, subi::ndo, para ver onde ele nasce.

263 - ANTONIA - Olha, eu também. (+) Consegue ver? Com o binóculo, com a luneta, né? (+) Mãe! Quer ver no meu? É bem lá em baixo, olha lá.

264 - LAURA - Aha::m

265 - MARIA - Você está ouvindo que ela faz barulho?

266 - LAURA - Tá vendo o barulhinho d'água, agora? Tá ouvindo?

267 - ANTONIA - Tô.

268 - MARIA - É bem relaxante, não é?

269 - LAURA - Ah, é. Dá para dormir aqui

270 - MARIA - Tá vendo, ó?

271 - ANTONIA - Ah, não. Tá cheio de sujeira!

272 - LAURA e MARIA - ((risos))

273 - ANTONIA - Tem aranha aqui!

274 - MARIA - ((risos)) Você não entende o espírito da coisa, né?

275 - LAURA - Você é uma menina da cidade mesmo ((risos)).

276 - MARIA - Ah, Meu Deus do Céu. (+) Olha, Laura, tem que ser mais ela pro mato, pra ela ir se acostumar. Fica apavorada com as coisas pequenas, imagina se leva ela no zoológico ou a algum lugar desse tipo.

277 - LAURA - A gente foge, as duas.

278 - ANTONIA - Gente tá perdida, acha mesmo? A gente tá quase indo lá.

279 - MARIA - Aí pronto, ai ela vai morrer mesmo de susto. Cada bicho que ela vê diferente que ela ver, vai grudar em você.

280 - ANTONIA - Mãe, no zoológico tem gato?

281 - LAURA - Tem um gato bem grandão.

282 - ANTONIA - Uhã::m.

283 - LAURA - Parente do gato.

284 - ANTONIA - Desse tamanho? ((se referindo ao tamanho do gatão)).

285 - LAURA - Não. Desse tamanho.

286 - ANTONIA - Desse tamanho? ((gesticula novamente))

287 - MARIA - A gente vai conseguir ver ainda.

288 - ANTONIA - A gente tá perdida. Acha mesmo? A gente tá quase indo lá.

289 - LAURA - A gente vai vê a semana que vem. (++) Ai que legal! As orelhinhas.

290 - MARIA - Tá vendo que bonitinho?

291 - ANTONIA - O que é aquilo? 
292 - LAURA - Hu::m. É tipo uns cogumelos que nasce, né?

293 - ANTONIA - Parece de mentira, tia.

294 - MARIA - Parece uma orelha.

295 - LAURA - É orelhinha, né?

296 - MARIA - Põe a mão!

297 - ANTONIA - Não.

298 - MARIA - Por que?

299 - ANTONIA - O que é aquilo grande?

300 - MARIA - É uma orelha maior. Ó, orelha da árvore. Ela também escuta. Sabia que você pode conversar com as árvores?

301 - ANTONIA - Tchau, árvore feia!

302 - MARIA - Por isso que a gente tem que respeitar as arvorezinhas, elas tem sentimentos.

303 - ANTONIA - Ah sei, então você faz (cogogof) (incompreensível) ?

304 - MARIA - Vamos?

305 - LAURA - Que legal, uma árvore enrolando na outra. São três árvores diferentes, quatro. Elas enrolam uma na outra. (+) Viu que legal? Parece uma só.

306 - MARIA - Logo, logo a gente vai achar um passarinho, bem bonitinho.

307 - ANTONIA - Ah! Eu vou ver com o binóculos.

308 - LAURA - É assim que a gente encontrar. É que eles se escondem. Eles sabem que a gente tá aqui.

309 - ANTONIA - Sério? Acho que eu vi um bicho preguiça lá em cima.

310 - MARIA - Eu acho que o espetáculo são os seres humanos.

311 - LAURA e MARIA - ((risos))

312 - MARIA - Eu queria te dizer isso, mas acho que são. A gente está passando de dia, as pessoas tão vendo lá; a gente... Sei lá, olha com uns olhos.

313 - LAURA e MARIA - ((risos))

314 - LAURA - olha Antonia, tá vendo o tronco caído?

315 - MARIA - Eu tô me sentindo praticamente parte da fauna e da flora.

316 - LAURA - Quem será que quebrou isso aqui? Olha os troncos! Quebraram tudo.

317 - MARIA - Deve ter sido a chuva. Foi, por que...

318 - LAURA - Faz tempo que não chove, mas quando choveu, choveu forte.

319 - ANTONIA - É derrubou as árvores 
320 - LAURA - Ó você está ouvindo? Deve ter algum bichinho aqui. (++) Ali tem toca de alguma coisa, Antonia! Um buraquinho ali.

321 - ANTONIA - Tô vendo.

322 - LAURA - É toca de algum bichinho.

323 - ANTONIA - Deixa eu ver.

324 - LAURA - Tá vendo ali, que tem um buraco?

325 - MARIA - Ai que legal! Será que não é uma lontra, não? Um tatu?

326 - ANTONIA - Sei lá.

327 - LAURA - Tatú? Aqui tem tatu. Tutuzinho.

328 - ANTONIA - Tô quase vendo aqui. Aí...

329 - LAURA - Parece toca de algum bichinho

330 - MARIA - Cê viu, que legal?

331 - ANTONIA - Eu não tô conseguindo ver

332 - LAURA - Deve estar dormindo. Na TV tem.

333 - MARIA - É ali ó, embaixo da plantinha. Tá vendo? Tá vendo o buraquinho? O bichinho fica ali dentro de um buraquinho

334 - ANTONIA - Tô vendo, não. Tá se mexendo.

335 - LAURA - Ué. Deve tá dormindo.

336 - MARIA - É verdade, dorme de dia pra poder sair de noite, igual criança danada.

337 - ANTONIA - Eu tenho medo de ficar aqui. pra que é isso aqui?

338 - MARIA - É pra você regular, olha em um ponto fixo, é para regular.

339 - ANTONIA - Ah, tá.

340 - MARIA - Que legal! Será que aqui é o final?

341 - LAURA e MARIA - ((risos))

342 - MARIA - Vem cá vê! Vamos ver o final, talvez a gente vê o bicho preguiça. (+) Ó deixa eu explicar um negócio pra você - Tá vendo? É aqui que nasce os rios, ó, vem desses lugarzinhos, tá vendo? Aqui é a nascentezinha. Aí a água, a chuva cai, molha aqui as plantinhas, e aí dessas plantinhas aqui, a água vai crescendo e vai para o rio. É como se fosse uma esponjinha que pega a água da chuva. É, é bem legal, tá vendo?

343 - ANTONIA - Ah!

344 - LAURA - Você gostou?

345 - ANTONIA - Vi

346 - LAURA - E tem bastante passarinho aqui, vamo?

347 - ANTONIA - Eu quero ver passarinho 
348 - MARIA - É que o passarinho está bem escondidinho.

349 - ANTONIA - Tá bom. O que a gente vai ver? O preguiça? Pode ser?

350 - LAURA - Que legal!

351 - MARIA - Vamos? Vamos mais, que na volta...

352 - ANTONIA - Acabou o caminho!

353 - MARIA - Então, agora a gente vai ter que voltar pra ver outras coisas.

354 - LAURA - Não tem mais rio.

355 - ANTONIA - Olha o Sol! (+). Vamos ver outras coisas. Cadê o macaco?

356 - MARIA - Os macacos? Eles ficam lá na frente. Bem lá na frente. O bom é que a gente vai ver as frutinhas deles, né? As comidinhas...

357 - ANTONIA - Hum. Ele tá lá comendo.

358 - LAURA e MARIA - ((risos))

359 - MARIA - Tchau Antonia!

360 - LAURA - Tchau amor ((risos))

361 - MARIA - Ué, Você está indo embora com as pessoas?

362 - LAURA e MARIA - ((risos))

363 - MARIA - É que vai dar tchau, fazer o que? ((risos))

364 - LAURA - Não, Antonia!

365 - MARIA - Olha, os bichos preguiças estão tão bem escondidos, eles estavam dormindo tão bem, que ele falou. O quê? Vai vir gente me visitar, eu vou é dormir. Eu tô com muita preguiça pra aparecer.

366 - LAURA - Calma.

367 - MARIA - Talvez a gente encontre ele ((bicho preguiça)), agora na volta, não sei.

Dá uma olhada bem assim, presta bem atenção que a gente vai encontrá-la. Deixa eu ver aonde a gente vai ver onde ela tá aqui. Vou ver no mapa aqui.

368 - ANTONIA - Olha! Posso ver o mapa?

369 - MARIA - Você quer ver o mapa? Ahãm. Peraí, segura.

370 - ANTONIA - A gente já viu o macaco, vamo?

371 - MARIA - Ahã::m.

372 - ANTONIA - Agora a gente tem que...

373 - MARIA - A gente tava aqui, ó, agora a gente tá vindo pá cá, tá vendo?

374 - ANTONIA - É. A gente precisa ir aqui.

375 - MARIA - É, aqui, pra volta.

376 - ANTONIA - Agora a gente tá indo até aqui, né? 
377 - MARIA - Isso!

378 - ANTONIA - Gente precisa com...

379 - MARIA - O mais legal é ver os macaquinhos!

380 - ANTONIA - Ah, os macaquinhos já foi. Já risquei. Vamos, mãe! Tô vendo nada!

381 - LAURA - A gente tava aqui, ó, no comecinho, chegando bem no comecinho da nascente. Agora a gente vai voltar.

382 - ANTONIA - Mãe! A gente foi aqui, fez isso daqui, foi aqui, tava indo, vimos as frutinhas.

383 - LAURA - Aqui que a gente viu isso aqui? Os cachos na mata? Não! Os "cactos" na matas!

384 - ANTONIA - Deixa eu ver.

385 - MARIA - Calma, calma!

386 - LAURA - Vamos ver se a gente acha. Ó, é aqui que a mamãe tem casa.((risos)) Eu tenho num vaso.

387 - MARIA - ((risos)) Eu não vi isso daí.

388 - ANTONIA - Deixa eu ver. Cadê?

389 - MARIA - A gente já foi por aqui; agora a gente tá bem aqui.

390 - ANTONIA - A gente tá onde agora, tia?

391 - MARIA - A gente tá... A gente tá chegando aqui ó, a gente vai entrar aqui agora.

392 - ANTONIA - A gente tá aqui, aqui. A gente tá aqui, né?

393 - MARIA - Só que você tem que olhar, senão a gente bate nas árvores. Daqui, deixa eu segurar o mapa.

394 - ANTONIA - Eu vou fechar o mapa!

395 - MARIA - Isso! Fecha o mapa, dá pra tia, que a gente tem que ver outras com a lupa, as coisas mais legais.

396 - ANTONIA - Vou fechar.

397 - MARIA - Daqui, daqui, deixa que a tia dobrar aqui pra você. Dá licença. Senão você vai amassar tudo aqui. Aí a gente não pode ver as coisas e ir nas sequências 398 - ANTONIA - Mas tem três binóculos?

399 - MARIA - Ó, essa árvore aqui, ó, dá um monte de frutinhas, cheia de coquinhos. Depois a tia vai mostrar os coquinhos pra você.

400 - ANTONIA - Cadê o coquinho? 
401 - MARIA - Então, depois a tia vai mostrar os coquinhos pra você, acho que os macaquinhos já comeram. Lá na frente a tia mostra, mas é essa aqui ó. E ali cai um monte de coquinho.

402 - ANTONIA - E o macaco vem aqui embaixo, pega e vai lá em cima?

403 - MARIA - Não. Na verdade ele come lá em cima; é que ele vai mexendo assim e algumas vai caindo, aí os bichinhos daqui que andam, os tatuzinhos que come o que cai no chão. Os tatuzinhos não sobem na árvore, eles são muito gordinhos pra subi. São quati e não podem subir nas árvores, não consegue subi.

404 - LAURA - ((risos))

405 - ANTONIA - Eu consigo, é assim

406 - MARIA - É, você já é muito medrosa; vê se consegue.

407 - ANTONIA - Eu tô, eu tô vendo.

408 - MARIA - Você é chorona. Qualquer coisinha você já chora. Vêm? Acho que aqui não tem preguiça, ô, Laura! Não aqui nesse pedaço.

409 - ANTONIA - Vamos ver os buraquinhos.

410 - MARIA - Daqui a pouco vamos ver os macaquinhos de novo.

411 - LAURA - Tem os macaquinhos.

412 - MARIA - Ah! Os macaquinhos é muito lindinho.

413 - LAURA - Bugios. (+) Você achou? Hem? Acho que aqui não tem preguiça, não.

414 - ANTONIA - Vamos ver o buraquinho

415 - MARIA - Daqui a pouco a gente vai ver os macaquinhos de novo. Mas é muito legal.

416 - ANTONIA - Eles não gostam de ficar em árvores pequenas, né? Igual essas?

417 - LAURA - A gente viu umas bonitinhas. Elas fecham o chão, todinhas.

418 - MARIA - Folhas grandonas, né? Você viu, que bonitas!

419 - LAURA - Não dá nem para fechar direito.

420 - ANTONIA - Ai, deixa eu ver

421 - MARIA - Vem!

422 - ANTONIA - Tô vendo uma garrafa.

423 - LAURA - Ó, as orelhas coloridas ali. São laranjas.

424 - MARIA - Ó as orelhinhas das árvores. Aqui, ó, tá vendo?

425 - ANTONIA - Ahã.

426 - LAURA - Que as árvores escuta, você sabe que as árvores escuta, né? Elas têm orelhinhas, igual você. Ó aquelas ali. Tá vendo? 
427 - MARIA - Parece um monte de florzinhas, bem laranjinhas. É onde elas escutam. 428 - ANTONIA - Ah! Tô vendo nada.

429 - MARIA - Você lembra que a gente tocou ali? Depois a gente perto de novo. 430 - ANTONIA - Não tô vendo nada.

431 - LAURA - Vem cá. São bem, bem laranjinhas.

432 - MARIA - Aqui ó.

433 - ANTONIA - Ah, tô vendo.

434 - MARIA - Bem laranjinhas

435 - ANTONIA - Tô vendo nada.

436 - MARIA - Procure. Procurou, achou?

437 - ANTONIA - Ahm, achei..

438 - LAURA - Viu? Ela tem um desenho amarelo e o resto é laranja. Perfeito, né?

439 - ANTONIA - Ah!

440 - LAURA - Aqui as raízes da planta.

441 - ANTONIA - Vamos gente. Vamos gente::.

442 - MARIA - Cipó? Não. Perai aí. Vamos andando. Deixa eu olhar o mapa onde a gente tá. Vocês não sabem olhar o mapa ainda. Se não você vai rasgar o mapa. Vamos andando 443 - ANTONIA - Ahãm.

444 - MARIA - Você tá vendo essa fruta aqui? Tem umas aqui que parece que a sua mãe tá na casa dela.

445 - LAURA - ((risos))

446 - MARIA - É tem uma ali, que parece que eu vi na sua casa. Vamos? Pegou tudo?

447 - ANTONIA - Hu-hum. (+) Agora vamos para casa? Mãe, mãe, tô quase ficando na casa dela, hoje

448 - ANTONIA, LAURA e MARIA - ((risos))

449 - LAURA - A gente não vai embora ainda. Tem um monte de coisa pra vê. Me fale uma coisa - o que mais você gostou?

450 - ANTONIA - Eu gostei do macaco; o-u-u-u ((imitando o ronco dos bugios)).

451 - LAURA - As frutinhas que eles gostam. Caem no chão e ficam só as casquinhas. Essas bolinhas no chão.

452 - MARIA - Olha aí, os coquinhos. É essa aqui, ó. Eles comem algumas e as outras caem no chão. São os coquinhos que tem lá naquelas árvores que eu falei pra você.

453 - ANTONIA - Deixei cair.

454 - MARIA - Tá com medo dos coquinhos? Mas não mordem, não. É frutinha. 
455 - ANTONIA - Eu sei. Algumas são molhadas?

456 - MARIA - São. Porque aqui é úmido.

457 - ANTONIA - Lá em cima é molhada, aqui é seco.

458 - MARIA - Não está mais sentindo frio?

459 - ANTONIA - Não tô mais; só minhas pernas.

460 - MARIA - ((risos)) Tá legal.

461 - LAURA - ((risos))

462 - ANTONIA - A gente passou dali; a gente vai indo lá

463 - LAURA - E essa daqui, dependurada? Esse tipo de flor?

464 - MARIA - Essa aqui, a vovó tem em casa.

465 - LAURA - Aqui a raiz dela vai até lá embaixo, Antonia.

466 - MARIA - Ela não é da árvore. É diferente; ela só se apoia, viu?

467 - ANTONIA - Não dá para tirar, mesmo.

468 - LAURA - Se segura na árvore para ficar mais no alto. Tem um monte, viu?

469 - MARIA - Legal, né?

470 - ANTONIA - É o bebezinho dela, Tá segurando ((risos)). É por aqui, porque tá soltando. $\mathrm{O}$ bebezinho tem um monte de irmão.

471 - MARIA - Olá, ó, sente a flor. (+) Tá chique

472 - ANTONIA - Tu-tu-tum

473 - MARIA - Deixa a tia ver um macaquinho?

474 - ANTONIA - É deixa eu ver.

475 - LAURA - É um negocinho.

476 - MARIA - Olá, ó. Deixa a tia ver um negocinho.

477 - ANTONIA - Deixa eu ver, deixa eu ver primeiro. É mesmo! Ele está bem pretinho.

Nossa! Olha o outro, a gente achou dois!

478 - MARIA - Tem mais ali.

479 - ANTONIA - ((sussurrando)) - Eu quero ver

480 - MARIA - ((sussurrando)) - pra titia ver. Tem quietinha. Tem um monte aqui.

481 - ANTONIA - pra que que é isso?

482 - MARIA - Não mexe aí, tó. Isso é pra gravar. Deixa ai, não mexe. Não mexe, não mexe nas coisas da moça. Tó, aqui ó. Vem aqui, tira a mão dai.

483 - ANTONIA - Onde tá a moça?

484 - MARIA - Tó, vem cá ver com o binóculo.

485 - ANTONIA - Tem mais ali. 
486 - MARIA - Ó, dá pra ver os rostinho deles, daqui

487 - ANTONIA - Aonde?

488 - MARIA - Aqui ó. Tá vendo ali?. Olha aqui. Olha a mãozinha dele. Tá vendo? Você tá olhando pra trás. É pra cá. Não, esse aqui ó. ((Sussurro)). Olha lá pendurado, tá pendurado pelo rabo por ali, ó, pendurado no cipó. Tá vindo pra cá.

489 - ANTONIA - Tá

490 - LAURA - ((Sussurro)). Olha lá, pendurado lá no alto. Olha lá, Maria. Se viu? Tem um pendurado pelo rabo logo ali.

491 - MARIA - ((sussurrando)) - Olha que bonitinho!

492 - ANTONIA - Hum.

493 - MARIA - ((sussurrando)) - Não pode fazer barulho.

494 - ANTONIA - ((sussurrando)) - Eu não disse. Ele acha que é balanço.

495 - MARIA - Não pode fazer barulho, senão ele assusta.

496 - LAURA - Aquele ali parece bebezinho, bem pequenininho; aquele ali é grandão.

497 - MARIA - Qual, fia? (+) Olha lá o bebezinho deles. É um casal. Daqui dá pra ver melhor.

498 - ANTONIA - É,eu me atrapalho.

499 - MARIA - Tem muita árvore na frente, né? Ah! Não! Ele saiu. Vamos ver o outro.

500 - ANTONIA - Tá subindo pra cá. O outro não tava.

501 - MARIA - Vamos ver o outro que tá balançando.

502 - ANTONIA - O outro não tava.

503 - LAURA - Tá alí, pulando, pulando pelo rabo. Logo ali, ó. Agora ele tá subindo lá em cima.

504 - ANTONIA - Ele tá comendo.

505 - MARIA - Eles gostam desse lugar, né?

506 - LAURA - Quentinho!

507 - ANTONIA - Hãhã. É.

508 - MARIA - Ele tem mais frutinha, um monte.

509 - LAURA - Tem um bem em cima da gente; se soltar o coquinho vai cair na nossa cabeça ((risos)).

510 - MARIA - Aonde?

511 - LAURA - Bem aqui, ó. E tem um aqui, ó, bem em cima da sua cabeça também, dá pra ver o rabinho dele.

512 - MARIA - Ah! Tô vendo. Eita! Bem com a bundinha virada. ((risos tia e mãe)) 
513 - LAURA - pra soltar o coquinho, vai cair assim: tum!

514 - MARIA - É. Mas se ele ficar meio assim, sabe?

515 - ANTONIA - É o cocô dele?

516 - LAURA - Não. É o coquinho que ele come, a frutinha.

517 - MARIA - É. Mas se ele ficar com dor de barriga... ele tá com a bundinha bem em cima da tiaaqui. ((risos tia e mãe)). A tia vai pensar que é um coquinho; é outra coisa.

518 - LAURA - Tá cheio de macaquinho aqui, Antonia!

519 - MARIA - Tem um monte, mas é só aqui nessa região, aqui; eles só ficam por aqui.

520 - LAURA - É. Lá pra frente eles não tão.

521 - ANTONIA - Mãe! Eu quero sentar.

522 - MARIA - Procure por aqui.

523 - LAURA - Lá para frente eles não estão.

524 - ANTONIA - Mãe! Quero sentar, sentar.

525 - LAURA - Senta só um pouquinho lá na gradinha.

526 - MARIA - Olha, Antonia, eles aqui, ó.

527 - ANTONIA - Tá caindo folhinha.

528 - LAURA - Eles estão passeando bem aí em cima.

529 - ANTONIA - Deixa eu ver com o binóculo?

530 - LAURA - Tá saindo ali, ó, descendo ali, ó

531 - MARIA - Eita, Antonia! Tá vindo pra cá, olha.

532 - LAURA - Agora que eu ia tirar foto!

533 - MARIA - "Vaípra lá”!Sabê o que fala. Deu a louca?

534 - LAURA - Olha que legal.

535 - ANTONIA - Aqui.

536 - MARIA - Deixa eu ver se dá ver mais de perto. (+). Ô, Antonia! Olha que interessante - Eles, sabem andar nas árvores! Só que eles são medrosos. Aqui, o que eles fazem para não cair? Eles amarram o rabinho na árvore, pode ver que eles andam segurando pelo rabinho, pela pontinha do rabinho, assim ó.

537 - LAURA - Ficando assim, preso que nem um dedinho.

538 - MARIA - Então eles vão andando. (+). Isso.

539 - ANTONIA - Assim, ó? ((gesticula))

540 - MARIA - É... isso mesmo!

541 - LAURA e MARIA - ((risos))

542 - MARIA - Eles seguram 
543 - LAURA - Olha, eles estão lambendo o tronco.

544 - MARIA - Porque eles têm medo de cair. Eles agarram a mãozinha assim, ó, na árvore.

545 - LAURA - Ta vindo mais um aqui, ó.

546 - MARIA - Eles agarram bem firme na árvore.

547 - LAURA - Coisinha mais linda.

548 - ANTONIA - Vamo gente.

549 - MARIA - Peraí. Agora a gente tá vendo ele diferente!

550 - ANTONIA - Cadê a moça? Ah tá ali.

551 - LAURA - Eles tão bem pertinho.

552 - MARIA - Olha, estão se beijando.

553 - LAURA - ((risos))

554 - MARIA - Casal! É papai e mamãe!

555 - ANTONIA - É mesmo. Tão se abraçando. Não. É o filhinho e o papai.

556 - ((sons dos guinchos dos macacos $))$

557 - MARIA - Tão chorando, olha! Eles tão falando: Olha, sai daqui. É o meu lugar.

Você tá pegando o meu lugar?

558 - LAURA - Que barulhinho diferente, né?

559 - MARIA - Tá parecendo você aquela hora.

560 - LAURA - Tá parecendo você! ((risos))

561 - ANTONIA - ((imitando os guinchos dos macacos)). Achei um gatinho. É igual a gente. Vai para lá e para cá.

562 - LAURA - Olhe lá, bem pertinho.

563 - ANTONIA - Sui-sui-sui ((chamando o gatinho))

564 - LAURA - Tem alguma coisa ali querendo voltar. Tá mordendo.

565 - MARIA - Será que elessão bebês?

566 - LAURA - Não sei, eles parecem bem menor que aquele outro. Bonitinho!

567 - MARIA - Vamos? Vamos dar tchau pros macaquinhos, que eles são lindos.

568 - ANTONIA - Vamos. Eu chamei pra vocês e vocês não vamos.

569 - MARIA - Ah! É que a gente conseguiu ver direitinho agora, e eles estavam reclamando, sei lá. Muito lindinhos, né?

570 - LAURA - Olha, eles são muito fofos! Olhá lá, olha lá. O rabinho dele, enroladinho para ele não sair.

571 - ANTONIA - Dá o binóculos. 
572 - LAURA - Eles são ruivos, né? ((risos))

573 - MARIA - ((risos)) É. São da sua família, Laura.

574 - LAURA - ((risos))

575 - MARIA - São tudo alemão. Vem! Eles são tudo coqs. Vamos!

576 - LAURA - Quase derrubou uma folhinha.

577 - ANTONIA - É, mas a gente não foi lá.Tá caindo folhinha. Vamo!

578 - MARIA - Ele quase derrubou folhinhas. ((risos)) (+). Essa sua filha veio de encomenda. ((risos)) (+). Ela sabe fazer bem natural. Vem. Finge que não tá me vendo. ((risos)) (+). Vem! (+) Oó, naturalidade é com a Antonia. ((risos)) (+) Se qué fazer assim alguma coisa, ó, faz de conta, conta pra ela, ela conta tudo meio make-in-off durante a filmagem. (+). É uma coisa louca. ((risos))

579 - LAURA - Ela disfarça bem.

580 - MARIA - Ela não vai contar toda a parte que geralmente fica nas entrelinhas, né? Aquilo que geralmente a gente fala meio make-in-off do filme. Não, não. Com ela você não pode filmar, a não ser que você queira uma coisa rústica, assim, bem natural.

581 - ANTONIA - Ei! Eu tô andando aqui, mas está... ((cantarolando e balbuciando consigo mesma))

582 - MARIA - Olha, Antonia, vamos pegar aqui nessa área, vem, parece um bichinho de pelúcia.

583 - LAURA - Não tem formiga nela. Parece que tem pelinho.

584 - MARIA - Tá parecendo um tapete, ó. Isso aqui é tudo graminha.

585 - LAURA - lgual tapete da vovó. Mamãe, se passa a mão assim, você vai com o dedo. ((risos))

586 - MARIA - Ela morre de medo. Óh, húuu

587 - LAURA - Parece que tem cabelinho.

588 - ANTONIA - E aquilo lá parece

589 - LAURA - E aquele negócio vermelho?

590 - MARIA - É ó, essa árvore aqui, ela é saudável, tá vendo?

591 - LAURA - Hã?

592 - MARIA - Aqui ó. Essa aqui tá cheia de vida. Ela já passou no médico.

593 - LAURA - Já, e ela era grandona, no tronco, ela tem idade maior.

594 - ANTONIA - Ela não passou no médico, não. Tá toda quebrada.

595 - LAURA - Tá sim, amor, ó a casquinha dela, ó.

596 - MARIA - Tá vendo? Por isso que os macaquinhos não caem, ó. É forte! 
597 - ANTONIA - É dura!

598 - MARIA - É dura. É firme. Eles têm as mãozinhas deles, eles agarram, mas como eles são pessoas cuidadosas, eles...

599 - ANTONIA - Eles fazem assim, ó - Uhú, Ahá.

600 - MARIA - Eles são criaturinhas cuidadosas, eles...

601 - ANTONIA - Ele não fica segurando no galho e balançando.

602 - MARIA - Não, porque eles não são macaquinhos peraltas igual você. Eles são obedientes.

603 - ANTONIA - Eu não sou ma-ca-qui-nha!

604 - LAURA - É uma macaquinha muito peralta!

605 - ANTONIA - Mãe!

606 - LAURA - Oi!

607 - ANTONIA - Quer ouvir uma piada? Você é um macacon!

608 - LAURA - ((risos)) E mamãe é a maior? Olha aqui, mais.

609 - ANTONIA - Vamos aí em cima.

610 - MARIA - Você viu que legal? Você quer ver com a lupa, agora? Esse aqui, no tamanho, dá para você ver.

611 - LAURA - É bom olhar mais de perto.

612 - MARIA - Deixa eu pegar a lupa, deixa eu ver onde botei aqui na bolsinha. Ó, deixa que a tia pega.

613 - ANTONIA - Eu sei

614 - MARIA - Tá vendo? Ó, esses negocinhos vermelhos. Assim, ó. Aqui, ó, mais

615 - ANTONIA - Só quero ver.

616 - MARIA - Viu que legal?

617 - LAURA - Se viu que algum...

618 - ANTONIA - É igual um binóculos

619 - LAURA - ... Fez um desequilíbrio; ficou super abundante.

620 - MARIA - Interessante, né? Não pode ser nem demais, nem de menos.

621 - LAURA - É. Agora eles tão vendo de fazer o sombreamento para ele não desenvolver ou remover o bambu.

622 - ANTONIA - Olha, manchinhas!

623 - LAURA - Você viu como ela é alta?

624 - ANTONIA - Manchinhas de belezas!

625 - MARIA - Você viu? Que legal! 
626 - ANTONIA - Tem manchinhas desta.

627 - MARIA - É, mas essas aqui que é legal. Parece que pintaram elas.

628 - LAURA - Coloridinhas.

629 - MARIA - Coloridinhas. Isso aqui não foi ninguém que fez. Foi a natureza, mesmo.

Tá vendo? Quando a árvores tem essas manchinhas, é porque que ela está respirando.

Está bem de saúde. Viu?

630 - ANTONIA - Elas têm monte de nariz.

631 - MARIA - Nariz, não. Isso aí é manchinha.

632 - ANTONIA - Ah, uma "manchinhona"!

633 - LAURA - É como se ela tivesse sangue, só que as árvores não têm sangue.

634 - ANTONIA - É. Ela tem azeite

635 - MARIA - Tem o que? ((risos))

636 - ANTONIA - Tem azeite, igual de sangue.

637 - MARIA - Como é o nome? ((risos)) Ai para, se não, não vou aguentar

638 - LAURA - Tem azeite ((risos)). Igual de sangue ((risos))

639 - MARIA - Não. Não é azeite. A mãe falou SEIVA.

640 - ANTONIA - Não!

641 - LAURA - ((risos))

642 - ANTONIA - Tem azeite, chega. ((risos))

643 - LAURA - Não é azeite, é seiva.

644 - ANTONIA - É azeite! Eu vou deixar cair.

645 - LAURA - Nãão!

646 - MARIA - Não é azeite e pare de graça!

APÊNDICE E - Transcrição da entrevista

TRANSCRIÇÃO DA ENTREVISTA - FAMÍLIA

PESQUISADORA - Bom, então vamos lá. Hoje, então, dia 28/07/2015, às 16:30. Eu tenho aqui, comigo, três participantes, a LAURA, a MARIA Vieira da Silva e a ANTONIA de Freitas. Vocês podiam me dizer, por gentileza, a idade, o nível de escolaridade, da ANTONIA também, e se você é formada, qual a sua formação?

LAURA - Eu sou a LAURA, eu tenho 25 anos, eu tenho ensino médio completo, trabalho na Prefeitura, sou concursada e só. A ANTONIA tem 4 anos e ela vai para a escolinha. 
PESQUISADORA - Ela está em qual série, já está no Jardim?

LAURA - Não, está na creche ainda. É a fumaça que a gente viu lá?

ANTONIA - Ahan. E viu o céu azul.

\section{PESQUISADORA - E o seu nome?}

MARIA - Eu sou a MARIA, eu tenho 40 anos, eu tenho o segundo grau completo, estou fazendo faculdade de Design Gráfico e eu trabalho numa empresa de call center, na parte administrativa.

PESQUISADORA - Está ótimo. Vocês costumam realizar que atividades de lazer, normalmente? Isso é só para eu identificar o grupo e saber as preferências de vocês.

LAURA - Olha, eu e a ANTONIA e o meu marido, que é o irmão dela, a gente vai muito mais em cinema, faz passeios em locais fechados. Assim, ao ar livre, a gente está fazendo agora, que eu saí de férias, para aproveitar e incluir ela no, conhecer a natureza. A gente foi para Minas, visitou vários lugares lá com lago e patos, então agora, aproveitando, eu vou levar ela no zoológico, mas, normalmente, a gente só vai no cinema, mesmo.

\section{PESQUISADORA - MARIA, onde costuma ir? Em parques...}

MARIA - Eu costumo sempre ir a um parque, que nem, eu estou de férias, agora, então eu até conversei com a minha cunhada, falei assim, "olha, queria levar a ANTONIA em parques, assim, que eu não conheço". Mas eu gosto de cinema, shopping, assim, mas eu gosto de ar livre. Eu sempre faço caminhada quando eu posso, assim. A gente resolveu... eu não conhecia aqui, esse local, eu falei, "ah, vamos lá, então".

LAURA - Eu vim aqui quando eu tinha treze anos.

MARIA - O nosso alvo é conhecer todos os parques de São Paulo, porque a gente sabe que tem muito lugar muito lindo. A gente ainda vai no Ibirapuera ainda, a gente marcou o dia, antes das férias acabar.

LAURA - Zoológico, Ibirapuera...

MARIA - São coisas, assim, diferentes. E ela é uma criança que gosta dessas coisas assim. Tem muita criança que fica voltada para o videogame ou pra shopping. Não, ela não, ela gosta de qualquer coisa que você fizer com ela.

LAURA - Tudo o que você levar, ela vai.

MARIA - Bastante coisa cultural, é bem legal, até teatro ela vai. Ela ama teatro. E a gente acha diferente, porque ela é muito pequenininha. Onde vai, ela fica, se comporta. Até, a 
gente fica assustada, porque às vezes não dá certo um programa e ela chora, porque ela quer ir naquele local teatral ou quer ir naquele parque. Mesmo sem saber. E esse é o meu lazer, aproveitar, como eu sou a tia coruja, pra passear com ela, também.

PESQUISADORA - Está certo. E museus, jardins botânicos, zoológicos, que são museus de ciências, é frequente a ida?

LAURA - Não, a gente vai, agora, no Catavento, para levar ela para conhecer algumas coisas diferentes, mas a gente nunca foi antes, não. Eu fui só quando eu era adolescente, que aí eu tinha o meu cunhado e a minha irmã, que eles me levavam, porque eles gostam desse tipo de passeio. Mas agora, com ela, eu vou começar a partir dessas férias a incluir nessa parte.

PESQUISADORA - Está certo, está certo. E, antes de ir para esses locais, vocês se informam pela internet, por telefone?

LAURA - Internet.

\section{PESQUISADORA - Internet?}

LAURA - Internet. Faço bastante pesquisa. Telefone, não. Faz pesquisa pela internet, pessoas que foram, o que fazer, os horários.

PESQUISADORA - E por que que vocês, normalmente, buscam essas informações antes?

LAURA - Para ter mais segurança quando vir no local, não ter nenhuma surpresa ao chegar estar fechado, ou então não saber se tem banheiro ou não tem. Local para comer. MARIA - Se é seguro, também.

LAURA - Com criança, é mais complicado para sair. Aí precisa ver se o local é seguro, que nem ela falou. Se dá para ir de ônibus, porque, às vezes, de carro, não tem lugar para parar. Aí se der para ir de ônibus, a gente vai de ônibus.

PESQUISADORA - Legal, legal. E para essa visita de hoje, vocês se informaram antes?

LAURA - Sim.

MARIA - Sim. 
PESQUISADORA - Onde, como?

MARIA - Internet.

LAURA - No site da Prefeitura de São Paulo, que fala sobre o Jardim Botânico, e alguns blogs de pessoas que vieram e falaram sobre como que é o passeio, fazer piquenique e tal. Aí a gente já veio preparado para o piquenique.

ANTONIA - Olha, muito Sol.

PESQUISADORA - Olha, que lindo, me explica o que são esses desenhos.

ANTONIA - Essa fumaça, essa fumaça vai, vira pro Sol.

PESQUISADORA - Nossa!

LAURA - Ela é muito criativa.

ANTONIA - Põe na minha bolsa. Me dá minha bolsa, mamãe.

LAURA - Deixa a moça perguntar.

PESQUISADORA - Vocês já conheciam a Trilha da Nascente? Essa trilha.

LAURA - Não.

MARIA - Não.

PESQUISADORA - Quando você veio não tinha?

LAURA - Quando eu vim aqui, eu tinha treze anos, faz um tempinho, faz doze anos, eu nem sei se tinha ou não.

ANTONIA - Pra que que é isso?

MARIA - É a lupinha.

PESQUISADORA - É a lupinha, para você ver de perto. Vocês acharam que esse material fornecido, então, a lupa, o monóculo, lápis de cor, ele auxiliou a visita? MARIA - Sim.

LAURA - Ah, sim, bem mais legal para observar, que nem, os macaquinhos que eu estava vendo, é diferente você ver mais de pertinho o rostinho, tudo.

MARIA - As frutinhas, deu pra gente ver as frutinhas. Porque, de longe, parecia preto. Quando eu olhei com a lupa, era vermelhinho. Interessante, deu pra ver melhor, sim. 
PESQUISADORA - Entendi. E o roteiro, vocês acharam que ele ajudou, que ele fez alguma diferença? Não fez? O que que vocês acharam do roteiro?

LAURA - Eu achei que foi bom, fez diferença, porque faz a gente ficar mais atenta ao que a gente vai encontrar. Não é só você entrar assim e ir andando, ele ajuda você a procurar exatamente o que pode ter ali. Eu acho que ajudou bastante.

PESQUISADORA - Vocês tiveram...

MARIA - Para de mexer!

LAURA - ANTONIA.

MARIA - Não mexe no negócio da moça. Olha o que você fez, você acabou com a gravação da moça. Tira a mão daí.

LAURA - Desculpa, moça. Crianças.

PESQUISADORA - Fica tranquila. Vocês tiveram alguma dificuldade de usar algum desses materiais?

MARIA - Não.

LAURA - Não, foi facinho, até ela conseguiu mexer direitinho. A gente explicou só uma vez.

PESQUISADORA - Vocês chegaram a observar as placas durante as trilhas, as placas das trilhas?

MARIA - Ahan.

LAURA - Ahan.

PESQUISADORA - E vocês chegaram a ler essas placas?

MARIA - Sim.

LAURA - Sim.

PESQUISADORA - Em quais momentos vocês paravam? Teve a ver com o roteiro ou não, foi espontâneo de vocês? Foi por que o roteiro pedia para vocês lerem as placas ou vocês leram espontaneamente?

LAURA - Não, foi espontâneo. Tem placa, lá tem informação, então vamos ler. 
PESQUISADORA - Mas, no roteiro, vocês chegaram a ver, em algum momento, que tinha dicas para ler as placas ou nem repararam nisso?

MARIA - Não, a gente viu. Que nem, que tinha uma árvore lá que eu achei legal, que ela tinha uns negócios vermelho, e ali estava falando que fazia parte da respiração da árvore, ou seja, que aquela árvore tinha aqueles negócios vermelho, era que mostrava que ela estava com saúde. Eu achei interessante, porque se a gente não tivesse olhado o roteiro, a gente só ia bater, ver a árvore manchada.

LAURA - É, via um monte de manchinhas, às vezes até achava que era coisa ruim...

MARIA - E ia embora. Mas aí, como a gente leu o roteiro antes, a gente viu que tinha umas manchinhas vermelhas e aí eu até expliquei para ela, eu mostrei com a lupa para ela ver direitinho, então foi bem diferencial, mesmo.

LAURA - Eu não tinha visto que o roteiro falava para ler as plaquinhas.

MARIA - Eu não, eu li, eu li o roteiro, assim, e fui mostrando para ela.

LAURA - Eu li o roteiro, mas eu não vi que ele falava "leia a placa".

PESQUISADORA - Então, na verdade, isso mesmo, você teve uma boa sacada. Essas manchas, que são coloridas, podem ser verdes, brancas, vermelhas, não importa, elas são os líquens e elas dizem que, na verdade, elas são consideradas bioindicadores. Então elas indicam que a qualidade do ambiente está boa. Na verdade, não é que é ela ajuda a árvore respirar, ela ajuda a gente, que está de fora, a saber que esse é um ambiente saudável. Então se eles não tivessem aqui, provavelmente, quando eles estão aqui, na verdade, eles ajudam a gente a identificar que o ambiente está em equilíbrio.

LAURA - Legal.

PESQUISADORA - O que vocês mais gostaram na trilha?

MARIA - Ah, eu gostei da nascente, que é muito legal ver como é que começa, o início dos rios, geralmente a gente já vê, assim, o rio já, e ver a fonte dele, o começo dele, ainda mais para explicar para ela, é bem interessante, porque a gente, quando vai na praia ou vai num riacho assim, a gente já vê o rio lá pronto. Mas tudo tem um começo, até os rios. Então eu, particularmente, o que mais gostei foi de ver os rios e os macaquinhos, que é a distração ali, eles são bem bonitinhos. E a gente conseguiu ver com a lupa lá eles bem pertinho, eu vi o rostinho deles bem detalhadinho, que, de longe, a gente não consegue 
identificar as frutinhas deles. Deu pra ver a cor da frutinha que eles comem, tal. Algumas coisas, assim, diferente. Foi o que eu mais gostei, assim.

PESQUISADORA - E você, La?

LAURA - Eu gostei do caminho, assim, no alto, porque você não fica, às vezes atolando, se perdendo, você fica, segue o caminho certinho. E das árvores no meio do caminho, que eles não cortaram. Eu achei legal, eles construíram em volta a trilha.

PESQUISADORA - E você, Antônia, o que que você mais gostou nessa trilha? Me conta.

ANTONIA - Dos macacos.

PESQUISADORA - Dos macacos? Quantos macacos você viu, hoje? Dois? Que legal, que legal.

ANTONIA - Eu vi um pendurado de rabo, outro gritando.

PESQUISADORA - Você já tinha visto algum macaco um dia na sua vida? Não? Primeira vez que você viu macaco?

LAURA - É a primeira vez que você vê macaco, ao vivo é.

PESQUISADORA - Ai, que legal. Como vocês se sentiram ao longo da trilha? ANTONIA - É assim, o meu.

PESQUISADORA - Nossa, que nome bonito, ANTONIA.

LAURA - Guarda na sua bolsa e deixa a moça perguntar.

ANTONIA - ANTONIA.

PESQUISADORA - Como é que vocês se sentiram, do ponto de vista emocional, sensorial, de vocês, de vocês poderem tocar, ver, sentir, o que que vocês, como que vocês se sentiram, vocês podem me descrever?

LAURA - Ah, é muito prazeroso você tocar nas coisas, sentir que tem vida em volta, é bem mais legal. Eu gostei. Fica bem relaxada. A gente vive na correria lá, tudo cinza, tudo de tijolo e cimento, aí quando você vê, assim, que tudo tem vida em volta, é muito legal, bem relaxante. 
MARIA - É, o fato de você estar aqui já, no parque, já é relaxante, até estava conversando com ela, quando a gente chegou, a gente deu uma volta, depois a gente fez o piquenique, ficamos um tempo sentado, só relaxando, porque quem vem num lugar desse, é porque quer isso, mesmo, não é nada que quer. Até brinquei com ela, "você está ouvindo?”, ela não está ouvindo nada, justamente, é isso, é isso que eu queria que você ouvisse.

LAURA - Esse é o ponto.

MARIA - Não ouvisse nada, porque a gente está acostumado com muita poluição sonora, é carro, música, vizinho, na escola, no trabalho, que nem, eu trabalho num lugar que tem muito barulho. Então, às vezes, você quer isso, você quer, totalmente, o que você não tem, que é silêncio. Eu amo o silêncio. De vez em quando a gente precisa e o melhor lugar para você ter isso é aqui.

LAURA - Onde a gente mora é difícil ter silêncio.

PESQUISADORA - Vocês moram aqui em São Paulo?

LAURA - São Paulo é muito terrível. Ali, no João Clímaco.

PESQUISADORA - Vocês moram perto de mim, então. E ela mora em São Caetano?

LAURA - É bagunçado, né?

PESQUISADORA - E você, Antônia, como é que você se sentiu na trilha? Você sentiu frio, que eu vi.

LAURA - É, sentiu frio.

PESQUISADORA - Você percebeu que teve alguma mudança de temperatura ao longo do caminho? Ela está com vergonha.

MARIA - Fala com a moça, estava falando até agora.

PESQUISADORA - Ela sacou, porque.

ANTONIA - Eu, eu abaixei a cabeça para pintar a unha da boneca.

LAURA - Não, ela está conversando.

MARIA - Fala com a moça, o que que você achou da trilha, que você estava andando, que você ficou brava com a gente.

LAURA - Você ficou com muito frio. 
PESQUISADORA - Você percebeu que lá a temperatura é diferente? É porque tem muita árvore.

LAURA - É, viu? Lá é mais friozinho, mais fresquinho.

PESQUISADORA - E tem um microclima ali, porque tem a nascente, que nem você explicou o ciclo da água. Teve algum detalhe que foi especialmente marcante, que você vai falar, "bom, vou levar isso para o resto da minha vida"? Algum conhecimento que vocês adquiriram e que vocês pensaram "nossa! eu não sabia disso".

LAURA - Das manchinhas.

MARIA - As manchinhas foi marcante, mesmo.

LAURA - Nunca ia saber que aquilo era um indicador.

MARIA - Não, porque a gente passa batido, que nem, eu gostei, também, da parte que ele estava explicando que as árvores são aveludadas. Geralmente, quando a gente vai em parque, se não é esses parques específicos, a gente abraça, brinca com as árvores, mas não presta atenção. Mas aqui não, aqui as árvores, como é um jardim específico, tem umas árvores com uma tonalidade diferente. Além dessas manchinhas, eu gostei também de pegar nelas, que elas são meio aveludadas, nunca tinha visto uma árvore assim, parece um carpete.

LAURA - É algum tipo de musgo, não é?

PESQUISADORA - É isso, isso mesmo.

LAURA - Eles são muito fofos.

PESQUISADORA - Tem ali musgos e líquens.

LAURA - É, então, é o toque, você poder mexer, é legal.

PESQUISADORA - Vocês acham que o olhar de vocês seria diferente? - essa pergunta até está no roteiro. Se, ao invés de ficar numa trilha suspensa, vocês estivessem pisando no próprio solo? (Pesquisadora)

MARIA - Sim, muda. Muda, porque...

LAURA - Você acha melhor estar no alto? Eu acho melhor. 
MARIA - Eu não vejo, assim, questão de ser melhor ou pior, eu vejo questão de diferença, mesmo, porque quando você está no alto, a sua tendência é ficar olhando para cima, mesmo, porque você já está no alto. Agora, quando você está andando no chão, que nem a gente brincou com ela agora há pouco, para tirar a meia dela, porque eu tirei o sapato, a mãe dela tirou o sapato. "ANTONIA, vamos tirar o sapato para sentir a terra", porque geralmente, em casa, a gente fica, "põe o chinelo, põe a meia, põe o sapato", por conta do piso frio. E aqui não precisa disso, então a gente falava, "tira o chinelo", e ela estava desesperada, porque acostumou, desde bebê, a pôr sapato, ficar brigando, "põe o chinelo, põe o sapato". Quando chegou aqui, que tinha que tirar, ela ficou em pânico, ela não soube lidar. Então, se a gente tivesse feito uma trilha caminhando, com certeza seria diferente, até eu acho que eu tiraria o sapato para sentir melhor a natureza, sentir melhor o chão. Tanto é que quando você anda descalço num lugar desse, não machuca o pé e é bom para descarregar as energias, tal, você se sente mais revigorado. E a gente queria que ela sentisse essa mesma experiência, mas ela estava apavorada com a situação.

LAURA - Estava, ela foi resolvendo andar de meia, pisou com a meia no molhado, deu um grito.

\section{PESQUISADORA - Você está com a meia molhada agora, Antônia?}

LAURA - Não, eu troquei, eu trouxe outra.

\section{PESQUISADORA - Ah, uma mãe prevenida.}

ANTONIA - Eu vou ir lá de novo, para molhar.

MARIA - Olha que interessante, geralmente criança gosta de se espojar, correr. "Vai, ANTONIA, corre, vai, aproveita, é seu momento". Grudou na gente, com medo, talvez até por conta de que ela nunca veio num lugar desse, foi a primeira vez, então ela ficou apavorada com a possibilidade de poder ficar livre. Então acho que se a trilha fosse, também seria divertido para gente, para ela.

LAURA - É.

MARIA - É, que nem, no alto, foi legal no alto, tal, mas no alto a gente fica meio preocupada, ah, não pode chegar muito perto, assim, para não cair, ela, tal, ela também tem medo de altura. Agora, assim, acho que não.

LAURA - Ah, eu já gostei no alto, porque eu acho que é uma experiência diferente, porque a gente fica, sempre vê a árvore ali só aquele pedacinho que a gente alcança, aí você vê mais pra cima é mais legal. Assim, uma visão diferente. 
PESQUISADORA - É, vamos lá. Vocês tiveram novas informações com o roteiro, além dessas?

MARIA - Não, teve, teve algumas árvores que falava aí no roteiro, que eram diferentes. Até a gente estava procurando uma, mas a gente não encontrou, que é uma que tinha os cachos, isso, eu não vi. Você viu essa árvore? Então, eu não vi no roteiro, eu não achei. A gente ficou procurando elas, mas eu não encontrei.

PESQUISADORA - O cacto espaguete é parecido com aquela planta que você viu as raízes e tal.

LAURA - Eu tenho ele em casa.

PESQUISADORA - É uma associação, só que, quer ver, deixa eu achar o roteiro, aqui.

LAURA - Eu tenho esse cacto em casa.

PESQUISADORA - Ele não é uma árvore, ele fica associado a uma árvore. Ele, na verdade, ele não prejudica, ele vive só associado a ela. E você consegue ver, em algumas árvores, olha ali, ó. Você consegue ver lá?

LAURA - Aquele gordinho?

PESQUISADORA - Está vendo aquele gordinho ali, ó? Não parece um espaguete? Lá em cima. Então, aquilo é um cacto espaguete. Você tem que olhar, mas tem que olhar bem lá em cima.

MARIA - Lá em cimão? Ah, estou vendo.

PESQUISADORA - Está vendo? Tem um outro ali que parece um cacho, também, está vendo? Tem aquele que está grandão e tem um outro ali, que está...

MARIA - Ah, então, foi esse aí que eu não tinha visto.

LAURA - Parece com a suculenta que eu tenho em casa, mas não é igual.

PESQUISADORA - Parece um espaguete.

ANTONIA - Mãe, é aquela de pontinho?

LAURA - É, tem um monte de pontinho. 
MARIA - O parque está fechando, tu viu ali? Ainda bem que a gente...

PESQUISADORA - Estou acabando.

LAURA - Já, já está fechando?

MARIA - Já, está só nós, aqui.

PESQUISADORA - Vocês perceberam o papel social do Jardim Botânico? Chegaram a ver que o Jardim Botânico tem algum papel para a sociedade ou não? MARIA - Você fala, assim, como assim?

PESQUISADORA - Vocês acham que o Jardim Botânico, ele tem um papel de informar algo a alguém, de fazer uma pesquisa?

MARIA - Ah, sem dúvida.

PESQUISADORA - Por que que será que esse Jardim Botânico está aqui, por que será que ele é importante para a sociedade?

MARIA - Olha, hoje, a gente vive numa sociedade onde as pessoas, elas vivem muito em busca do seu sustento, digamos assim, de correr atrás de ganhar seu dinheiro, de carreira e coisa e tal. Então, quando a gente tem a oportunidade de vir num parque como esse e outros que a gente têm em São Paulo, é uma forma da gente conseguir parar aquele ritmo que a gente ouve muito falar na televisão, que a gente tem que comer bem, que a gente tem que que fazer exercício, tal, só que por conta da nossa vida corrida, a gente não consegue. Então, fazer uma coisa como essa, assim, é um privilégio. E o mais legal: barato. Porque não custa nada você poder sair da sua casa, mesmo que você gaste a gasolina, carro ou se você gaste um ônibus, é muito barato e é uma diversão que é muita coisa que você aprende, não é uma coisa só, além de você respirar melhor, você pode ensinar um monte de coisa para a criança, você poder aprender um monte de coisa, é um momento que você consegue parar e relaxar. É uma coisa que, geralmente, a gente não consegue.

PESQUISADORA - E você acha que tem pesquisa sendo desenvolvida aqui?

MARIA - Ah, com certeza. 
LAURA - Com certeza. Muitas espécies diferentes. Em todo lugar que você olha tem várias e várias plantas diferentes, então, com certeza deve ter pesquisas desenvolvendo plantas, por exemplo, que estão em extinção, fazer o manejo pra...

MARIA - Eu vi uma planta, agora há pouco, aquela planta só dá na água. Não conseguiria ver, a gente não conseguiria ver aquela planta, por exemplo, na feira ou em outro local, assim, só aqui na natureza, mesmo.

\section{PESQUISADORA - Ali no Lago das Ninfeias?}

MARIA - É, a gente observou isso. Então são coisas pequenas, mas ricas, bonitas, a gente tem muita coisa linda.

LAURA - Tem um monte de girino que a gente viu.

MARIA - Essa daqui mexendo com os sapinhos, lá. Então é legal, a gente vê coisas, assim, pequenininhas, mas que deixa a nossa vida mais rica e é tão legal a gente poder parar e saber que a gente tem um lugar tão bonito e tão próximo, mas a gente não se dá conta disso. Geralmente, quando a gente vai pesquisar uma coisa dessa, está muito velha, já. É, que se você vai nos parques, só tem os velhinhos andando, fazendo as caminhadinhas. E em vez de videogame ou viver no shopping ou dar um brinquedo muito elaborado para a criança, esse aqui. Esse é o melhor presente, isso aqui vai pra vida toda. E é isso que a gente tenta cultivar,pelo menos na nossa família, as pequenininhos a gente faz isso, tenta cultivar o amor e o respeito à natureza, porque sem isso aqui, a gente não estaria nem vivo.

\section{PESQUISADORA - É verdade.}

MARIA - É por isso que é importante preservar e a gente preserva, que nem, estava ensinando pra ela, “ó, está vendo? Isso aqui não pode”. A gente já tem que ensinar, lugar de garrafa, de lixo, é no lixo. Eu já mostrei pra ela, isso aqui não pode, isso aqui pode prejudicar a árvore.

LAURA - E essas coisas marcam muito mais ela ver que não pode, explicar, do que você simplesmente falar, "não pode, viu?”. Ela viu que está no lugar que tudo é verde, só tem aquela garrafa lá jogada no meio.

MARIA - E chama atenção, que ela ficou, você viu, atrás do papel, ela ficou, então é legal, isso é uma forma de aprendizagem, a gente ensina sem precisar, mostrando. Então, pra gente, é bem bacana, até combinei com ela da gente ir em outros parques, tal. Esse foi o primeiro do roteiro, tem muitos parques em São Paulo, muito lindo, é que é longe, mas 
a gente está vendo aí os que a gente pode ir antes de acabar nossas férias, aproveitar aí com ela, que é divertido, porque ela é bem divertida, ela é uma criança, assim, engraçada. A gente se diverte um pouco.

PESQUISADORA - Vocês acham que a Trilha da Nascente tem um papel para o Jardim Botânico?

MARIA - Sem dúvida.

PESQUISADORA - Qual o papel dela? Por que que vocês acham que ela é importante?

MARIA - Eu acho importante porque é uma forma de você saber que tudo tem uma origem. Que nem eu falei no começo, às vezes a gente olha um rio ou a gente vê o mar, mas tem uma origem disso tudo, é legal. Que nem, quando eu vou na praia, eu gosto de ir no final, de uma ponta à outra da praia, para saber até onde vai a extensão ali, que é bem legal. E, geralmente, no canto das praias, tem aquelas montanhas, tem umas rochas, é bem legal. E no caso do rio também, que nem, por exemplo, a gente ouve falar que tem muito rio poluído, como o rio Pinheiros, o rio Tietê, mas a nascente deles dá para você nadar, dá para você beber água, e as pessoas não sabem disso, a gente sabe pela televisão, às vezes, quando, que nem, quando, agora, estava até brincando com ela, que objeto de luxo, hoje, é ter água, por conta dessa falta de água, da falta de chuva e tal. E mostrar isso para a criança também é bacana, que nem eu falei para ela, "é aqui que nasce o rio". A criança nem sabe que o rio tem uma origem, que nem ela teve. Então é legal, a gente viu os sapinhos, mostrou pra ela, ó, até a gente conseguiu achar um sapo maior e os filhotinhos, “ó, está vendo? O sapo nasce desse jeito, tal”. Então a origem das coisas é muito legal, a gente saber até para a preservação, porque às vezes as pessoas não sabem. Que nem, a gente encontrou muito lixo e eles não sabem que ele prejudica a natureza e, se prejudicar a natureza, futuramente vai nos prejudicar, só que eles não têm essa visão que a gente precisa ter, que é bem legal.

PESQUISADORA - A gente falou, então, do papel da trilha para o Jardim Botânico, qual que é a intenção e tal. E para a cidade de São Paulo, por que que vocês acham que essa trilha é importante? Essa trilha, ela é importante para os munícipes de São Paulo, para São Paulo, ela tem alguma importância, não tem? 
LAURA - Eu acho que tem, para eles se conscientizarem do, por exemplo, a gente vê sempre o rio sujo. Então, se os moradores de São Paulo viessem, olhassem, para eles verem que o começo dele não é sujo, quem sujou fomos nós mesmos. Eu acho importante, até a conscientização, tanto dos mais velhos como dos mais novos, para ver, justamente, a questão da origem, de como é na natureza. Que nem a placa lá falou, que "a mata protege a nascente e a nascente protege a mata". Eu acho muito importante, mas nem todos dão conta.

\section{PESQUISADORA - Vocês chegaram a ler o desafio que o roteiro propõe?}

MARIA - Não, esse aí eu não li, não. Não, é sério, eu confesso, eu não li essa parte, eu li mais essa parte aqui, porque é a que estava as explicações e eu achei interessante, porque o que acontece, a gente foi nas plaquinhas, então dentro das plaquinhas a gente foi procurando o que tinha o roteiro, mas nessa parte a gente não leu.

PESQUISADORA - Tudo bem. Mas vocês chegaram a, lendo assim, rapidamente, a gente viu vários elementos ao longo dessa trilha, várias coisas. Como é que vocês acham que eles interagem nesse ambiente, as coisas se interligam de alguma forma, não?

MARIA - Não, sim, sem dúvida.

PESQUISADORA - É que você acabou de falar da mata e na nascente. Por exemplo, o bugio, ele tem um papel, também, pra manutenção dessa mata? Como é que as coisas acontecem pra que isso esteja em equilíbrio e a gente tenha esses indicadores, que nem a gente viu?

MARIA - Ela estava falando, a gente estava olhando uma placa, que estava explicando que está cheio de bambu aqui e um pessoal que cuida do parque estava vendo como é que ia manter o controle, porque se uma espécie sobressair à outra, acaba prejudicando as outras, também. Então até mesmo dentro da natureza tem que ter um equilíbrio, não pode ter uma espécie demais nem de menos. Porque prejudica, também, a alimentação dos outros bichos e tal, então eu achei interessante, que ela falou que eles estavam... o que que eles estavam fazendo?

LAURA - Eles estão estudando para ver como que eles vão fazer, se eles vão, três formas: eles vão tirar os bambus que estão em excesso ou eles vão tirar a iluminação, deixar mais 
escuro, que eles não procriam muito, e plantar mudas de outras plantas pra ter o equilíbrio melhor.

MARIA - Então, isso aí a gente reparou. Tudo está interligado, então uma planta não pode sobressair à outra. E o fato dessa área que está sendo preservada, não foi ninguém que criou isso aqui, isso aqui já veio há milhares de anos. Isso mostra a importância que tem uma planta na outra, porque, às vezes, a gente nem presta atenção.

LAURA - Então, e o negócio do bambu começou, justamente, porque eles cobriram a clareira, foi o próprio homem que desequilibrou, abrindo.

PESQUISADORA - Agora eu vou falar a última coisa, que eu achei muito bacana daqui, desse roteiro, que eu vou falar do roteiro. $O$ ser humano, então, ele interage de várias formas na trilha, né? Me fala como que vocês acham que o ser humano pode se fazer presente, as diversas formas que o ser humano se faz presente nesse trilha, o que que vocês acham?

LAURA - Do lado bom ou do lado ruim?

\section{PESQUISADORA - Dos dois.}

LAURA - Tem o lado ruim, que eles abriram o caminho e acabou desequilibrando um pouco e aí, pelo menos, eles não cortaram todas as árvores do caminho, mas tenho certeza que uma ou outra foi tirada fora do caminho pra fazer a trilha. E tem o lado bom, que a gente pode interagir.

\section{PESQUISADORA - Vocês acham que a trilha oferece alguma contribuição científica?}

MARIA - Sem dúvida, porque é uma forma até da gente conhecer, de uma forma, na prática, porque ler uma coisa e você ver aquilo que você está lendo, você poder tocar, sentir, cheirar, isso aí é um conhecimento que vai para a vida toda, porque fica na sua mente ali, aquilo lá não sai, quando você só lê uma matéria num livro, vê uma pesquisa na internet, é uma coisa, mas você poder ver aquilo com os seus próprios olhos e ver vivo, porque é mais legal ainda, aqui está tudo vivo, não tem nada morto aqui. É bem diferente de você ver uma espécie num vidro ou você ver nas fotos que as pessoas tiram fotos nos museus, tal. É diferente, é muito legal.

LAURA - Um museu vivo. 
PESQUISADORA - Vocês acham que... vocês usaram todos os materiais? A lupa, o monóculo...

MARIA - Usamos.

PESQUISADORA - A lupa, ela serviu pra ver o que, o que que vocês chegaram a usar pra ver, a lupa?

MARIA - A gente de ver aquelas manchinhas, pra ver com mais detalhes, nós mostramos pra ela, tal, pra explicar pra ela porque que tinha aquelas manchinhas, tal, a gente viu com maior detalhe.

PESQUISADORA - O monóculo, vocês usaram?

MARIA - Usamos bastante.

LAURA - Pra ver as frutinhas.

PESQUISADORA - Lápis de cor chegaram a usar?

MARIA - Agora, né?

LAURA - Agora, no final.

PESQUISADORA - Vocês acham... já responderam essa. Já responderam essa, vocês já responderam essa, também. So, eu só preciso de uma coisa agora, o que que você registrou nesse espaço, me conta?

MARIA - Cadê o seu desenho?

PESQUISADORA - Cadê o seu desenho? Deixa eu só ver o seu desenho.

LAURA - O que que você registrou aqui?

PESQUISADORA - Já estamos na penúltima pergunta. Conta pra mim, que eu vou tirar foto do seu roteiro.

ANTONIA - Gostei de fumaça e um monte de Sol.

LAURA - Você viu fumaça no roteiro, no passeio?

PESQUISADORA - Me explica, pra mim, o que que você viu? Fala pra mim. ANTONIA - Eu vi o Sol e eu vi macaco. 
PESQUISADORA - Cadê o macaco, no seu desenho?

ANTONIA - Ah, eu não sei fazer.

PESQUISADORA - Não, pode só mostrar. Onde você acha que você desenhou o macaco? Não tem problema, não tem certo e errado.

ANTONIA - Eu queria desenhar aqui, mas pensei em outra coisa.

PESQUISADORA - Essa daqui é a neblina que você viu, as fumacinhas?

LAURA - Isso, ela falou, né amor? Que era fumaça que ia até lá em cima.

ANTONIA - É, como vai a fumaça azul no céu, vira um azul aqui; como a fumaça vermelha vem aqui, vira um vermelho; como a fumaça vem aqui.

LAURA - Porque a fumaça fazia o céu mudar de cor? Tem que entender, mais ou menos.

PESQUISADORA - Está ótimo. Vocês têm alguma sugestão para essa experiência com esse material? Vocês falaram assim, "ah, eu acho que você podia melhorar isso, aquilo". O que que vocês acham que eu podia melhorar? Agora pra mim.

MARIA - Que você podia melhorar?

PESQUISADORA - No roteiro, de repente na minha abordagem.

LAURA - Não, achei tudo tão bom.

MARIA - Achei bom, mesmo.

LAURA - É, tem bastante explicação interessante.

MARIA - A gente não se sentiu inibida, porque já era uma coisa que a gente ia fazer isso, mesmo, até a gente nem sabia que tinha.

LAURA - É, a gente estava vindo, só. Ia descobrir.

MARIA - Com certeza, a gente ia entrar lá dentro, só que, assim, o diferencial é que a gente teve um conhecimento melhor pra poder entrar na trilha e saber o que a gente poderia encontrar lá, porque a gente viu as pessoas vindo, indo e voltando, mas assim, as pessoas nem sabiam que tinha macaco, as pessoas não sabem que ali era nascente, algumas nem estavam lendo as placas. Só tinha curiosidade para chegar no final da trilha. A gente entende que, na verdade, o caminho é o passeio. O que tem no final. Tanto é que, quando a gente chegou, assim, a gente levou um susto, porque se a gente continuasse andando, andando, a gente ia, assim, "olha, que legal”, parando, olhando.

LAURA - Eu achei legal, não tenho nada para reclamar, não. Nem para melhorar. 